
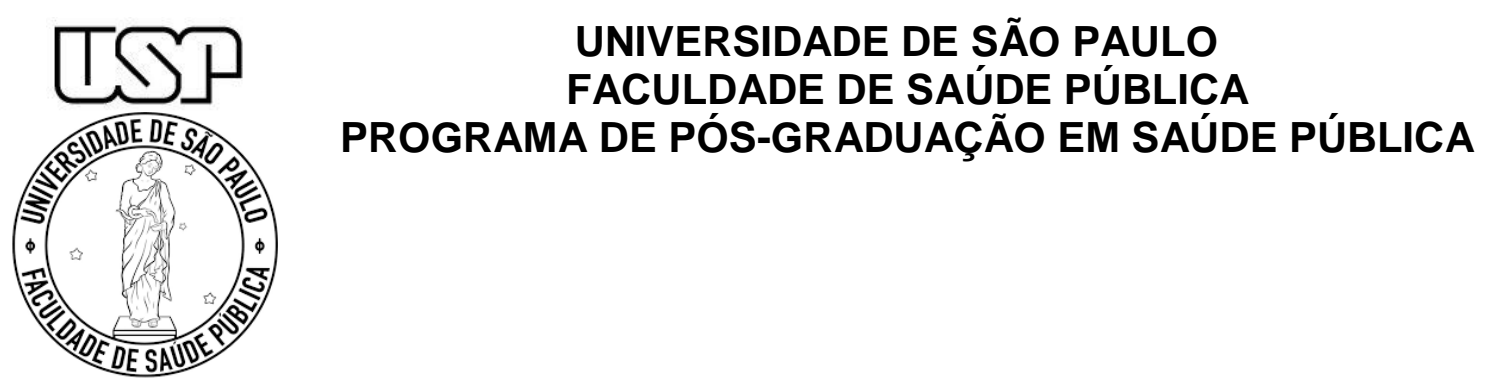

UNIVERSIDADE DE SÃO PAULO

PROGRAMA DE PÓS-GRADUAÇÃO EM SAÚDE PÚBLICA

Quando o Estado bate à porta - faces do Estado e narrativas sobre a juventude no atendimento socioeducativo na Zona Sul de São Paulo

Diego Sousa de Carvalho

Tese apresentada ao Programa de Pós-Graduação em Saúde Pública da Faculdade de Saúde Pública da Universidade de São Paulo (FSP/USP) para obtenção de título de Doutor em Ciências.

Área de concentração: Saúde Pública

Orientadoras: Prof. ${ }^{a}$ Dra. Aylene Emilia Moraes Bousquat

Coorientação: Prof. ${ }^{\text {a }}$ Dra. Cleide Lavieri Martins 


\title{
Quando o Estado bate à porta - faces do Estado e narrativas sobre a juventude no atendimento socioeducativo na Zona Sul de São Paulo
}

\author{
Diego Sousa de Carvalho
}

Tese apresentada ao Programa de Pós-Graduação em Saúde Pública da Faculdade de Saúde Pública da Universidade de São Paulo (FSP/USP) para obtenção de título de Doutor em Ciências.

Área de concentração: Saúde Pública

Orientadoras: Prof. ${ }^{a}$ Dra. Aylene Emilia Moraes Bousquat

Coorientação: Prof. ㄹ Dra. Cleide Lavieri Martins

Versão revisada 
Autorizo a reprodução e divulgação total ou parcial deste trabalho, por qualquer meio convencional ou eletrônico, para fins de estudo e pesquisa, desde que citada a fonte.

O presente trabalho foi realizado com apoio parcial da Coordenação de Aperfeiçoamento de Pessoal de Nível Superior - Brasil (CAPES) - Código de Financiamento 001

This study was financed in part by the Coordenação de Aperfeiçoamento de Pessoal de Nível Superior - Brasil (CAPES) - Finance Code 001 


\section{Dedicatória}

À memória de minha avó, Izabel, mulher negra, cearense, rural, benzedeira, resistente. Que deixou na lembrança seu enorme coração e sua vontade. À minha mãe, ao meu pai. À toda ancestralidade que lutou para que eu estivesse e chegasse aqui.

Aos nordestinos e mineiros, aos retirantes e migrantes que vieram a São Paulo. Ao povo que sobreviveu e ainda (sobre)vive de batalhas pra garantir moradia na tangente da Cidade. Ao povo preto e periférico. Aos orixás e entidades que me guiam. Forças da natureza. À sabedoria que vem da academia, mas que vem da favela também. Forças da natureza. Ao Jardim Ângela, vertigem, Ao Capão Redondo, pecado. Forças da natureza. 


\section{Agradecimentos}

Primeiramente, a Deus e aos orixás.

Às minhas orientadoras: À Prof. ${ }^{a}$ Cleide, por ter sido humana. E isso, sobretudo, foi o mais importante para que este trabalho se concluísse, quando nem eu mesmo achei que fosse possível. À Prof. $^{\text {a }}$ Aylene por sua leitura atenciosa e suas importantes contribuições para este trabalho.

À CAPES, pelo financiamento parcial (durante um período) da minha pesquisa.

Aos professores que compõem a banca, Prof. ${ }^{a}$ Bete Franco, Prof. Jose Miguel e Prof. Cassio Silveira, agradeço pelas contribuições, em especial pela leitura sensível e recomendações feitas durante a pré-banca.

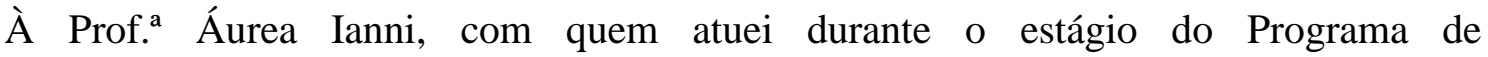
Aperfeiçoamento ao Ensino Superior (PAE/USP).

Às trabalhadoras, trabalhadores e ex-trabalhadores(as) da FSP/USP, que sempre me ajudaram. Especialmente, Renilda, Cidinha, Leandro, Vânia e Lygia.

À minha Mãe, Maria Helena, ao meu Pai, Jacó, à Mãe Rosana D’Oxum, ao meu companheiro Bruno Gomes, obrigado pelo apoio fundamental e por acreditarem em $\operatorname{mim}$.

Aos colegas, amigas e amigos que fiz nesta etapa de minha vida... Agradeço pelos diálogos, almoços no bandejão, discussões políticas, e vez ou outra uma cervejinha. Obrigado pelo afeto que compartilhei nesta Faculdade de Saúde Pública, num período tão complicado e difícil que foi a construção deste doutorado. Não serei capaz de nomear todos e todas, mas deixo registrado, Sabrina, Ana Sanches, Luna Gonçalves, Ailton, Selma, Andressa, Carol, Rubem Brandão, Cristiane Maymone, à memória de Alexandre Cruce... E a muitas outras pessoas que foram importantes.

Às amigas e amigos, nas pessoas de Mariana Faria, Roberta Faria, Susana Carla Ferraz. E à Jockastha a quem devo a ajuda fundamental com os mapas. A todos(as) que me motivaram a conhecer e me encantar pela temática das políticas sociais da juventude, Chico, Joyce, Carla Zulu, Fabiano Tassi, à memória de Taiguara...

Os anos de doutoramento foram, certamente, os mais difíceis que já vivi. Todo o processo exigiu de mim descontruir, questionar e duvidar, não somente sobre minha pesquisa, sobre o que é pesquisa e o campo acadêmico, mas, acima de tudo, sobre minha vida e sobre mim mesmo. E este é um dos mais árduos desafios que um jovem, de origem pobre, enfrenta num país que passa por crises, que pouco investe em educação, que dirá em pesquisa, depara-se ao trilhar esses caminhos. Dito isto, dedico este trabalho aos(às) jovens negros e/ou de periferia e origem pobre.

E, finalmente, agradeço imensamente a todas e todos os colaboradores da pesquisa, trabalhadoras e trabalhadores do sistema socioeducativo. Obrigado por compartilharem 
seus saberes e vivências, e por me ensinarem, pois o pesquisador vai a campo para aprender...

Somente o afeto pode retirar a mecânica das relações, e livrar do risco enlouquecedor da burocratização da vida.

Obrigado! 
CARVALHO, Diego Sousa de. Quando o Estado bate à porta - faces do Estado e narrativas sobre a juventude no atendimento socioeducativo na Zona Sul de São Paulo (Tese de Doutoramento). São Paulo: Universidade de São Paulo, 2019.

\section{RESUMO}

No Brasil, a história da infância, adolescência e juventude, enquanto instâncias sociais, configura um panorama marcado pelas trajetórias institucionais, inscreve-se certa fronteira que estabelece os sujeitos enquanto "moleques", "pivetes", "menores"; sendo que, o que determina tais categorias são, de fato, marcadores de pobreza e, muitas vezes, determinantes raciais. Ao longo dos anos, o Estado tratou institucionalizar e reprimir o direito ao convívio familiar e comunitário, como suposta "prevenção" aos jovens pobres.

A partir do estabelecimento do Estatuto da Criança e do Adolescente (1990) e do Sistema Nacional de Atendimento Socioeducativo (2012), mudanças são estabelecidas na compreensão, abordagem e condutas sobre a implicação de adolescentes e jovens em práticas de ato infracional. Estas políticas têm como prerrogativa trabalhar ações sociais e educativas em conjunto na condução da responsabilização legal do jovem infrator, pela premissa da proteção integral e promoção de direitos, entendendo haver um compromisso entre família, comunidade e Poder Público para defesa e garantia de direitos humanos fundamentais.

A pesquisa buscou compreender, a partir dos relatos de profissionais do sistema socioeducativo, o acesso aos programas e políticas do Estado pela juventude em conflito com a lei e moradora de periferias, na Zona Sul do Município de São Paulo. Foram realizadas entrevistas semiestruturadas junto a 16 profissionais que atuam no atendimento socioeducativo nas regiões do Capão Redondo e Fundão do Jardim Ângela (São Paulo - SP). A partir dos relatos, essas relações são descritas em sentidos complexos e conflitantes: muitas vezes, somente a partir da infração, o jovem e sua família são "incluídos" em políticas públicas socioassistenciais. Há uma compreensão, da parte dos profissionais, que o Estado aparece para o jovem periférico, a princípio, de maneira punitiva, através de ações policiais, pela violência ou pela internação na Fundação Casa. Em alguns casos, contudo, mobiliza também conteúdos afetivos, pelos vínculos que estes jovens desenvolvem com profissionais do sistema socioeducativo.

Palavras-chave: Juventude em conflito com a lei; Estado; Direitos Humanos; Capão Redondo; Fundão do Jardim Ângela 
CARVALHO, Diego Sousa de. When State knocks on the door - faces of State and narratives about the youth on the socio-educational system at South Zone of São Paulo (Doctoral Thesis). São Paulo: Universidade de São Paulo, 2019.

\begin{abstract}
In Brazil, the history of childhood, adolescence and youth, as social instances, configures a panorama marked by institutional trajectories, a certain border is established that discriminates the subjects as "moleques", "pivetes", "minors"; and what determines such categories are, in fact, markers of poverty and, often, racial determinants. Over the years, the State has tried to institutionalize and repress family and community living right, as an alleged "prevention" for the poor youth.
\end{abstract}

Since the establishment of the Child and Adolescent Statute (1990) and the National Socio-Educational Service System (2012), changes in understanding, approach and conduct are required on the involvement of adolescents and young people alleged implicated in practices of infraction. These policies have the prerogative to work social and educational actions together in the conduct of the legal responsibility of alleged offender adolescent, from the premises of integral protection and promotion of rights, and concern a compromise between family, community and Public Power to defend and guarantee fundamental human rights.

The research aims to understand, from the reports of socio-educational system professionals, the access to State politics and programs performed by youth in conflict with the law and living in periphery regions, at the South Zone of São Paulo. For this, semi-structured interviews were carried out with 16 professionals who work in the socio-educational systemby the regions of Capão Redondo and Fundão do ("Bottoms of") Jardim Ângela. From the reports, these relationships are described in complex and conflicting senses: often, only from the law infraction, the youth and family are "included" in social public policies. There is an understanding that the State firstly appears to the suburban resident young people in a punitive way, through police actions, violence or through incarceration at Fundação Casa. However, in some cases it also mobilizes affective contents, by the bonds that these young people develop with professionals of the socio-educational system.

Keywords: Youth in conflict with the law; State; Human rights; Capão Redondo; Bottoms of Jardim Ângela 


\section{SUMÁRIO}

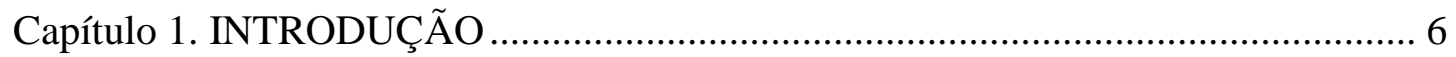

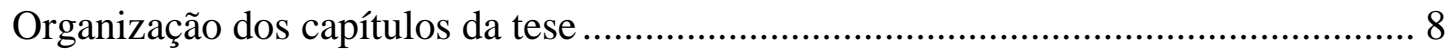

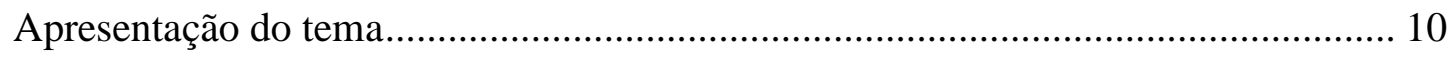

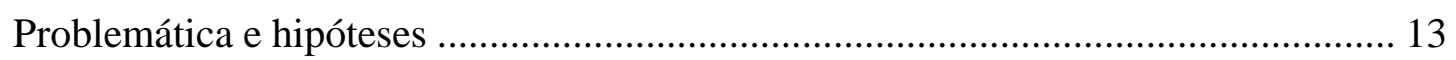

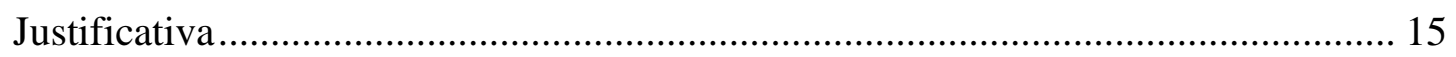

Possíveis relações com o campo da saúde pública................................................... 20

Capítulo 2. ASPECTOS HISTÓRICOS E PRODUÇÃO DICURSIVA ACERCA DO

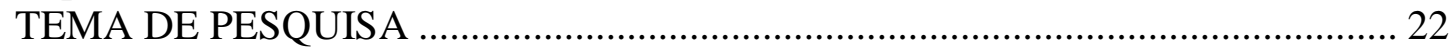

História social da infância e adolescência ................................................................ 22

Políticas sociais de infância, adolescência e juventude no Brasil .............................. 34

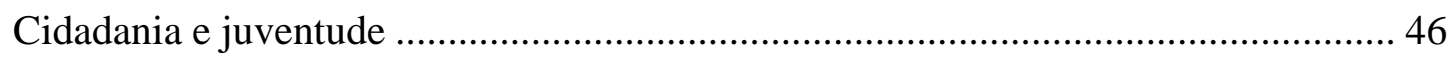

Estado, Estados, agentes do Estado, Poder, poderes ............................................... 50

Juventudes, crime, pobreza e violências: abordagens sociológicas............................ 56

Capítulo 3. CUIDADOS E ETAPAS DA CONSTRUÇÃO DA PESQUISA: DOS

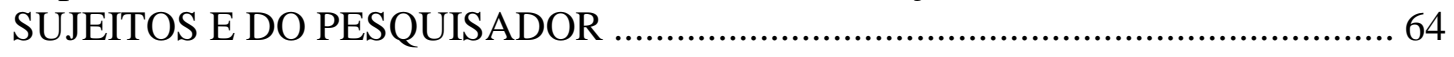

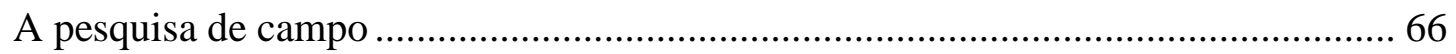

Sujeitos da pesquisa, territórios e organizações ....................................................... 70

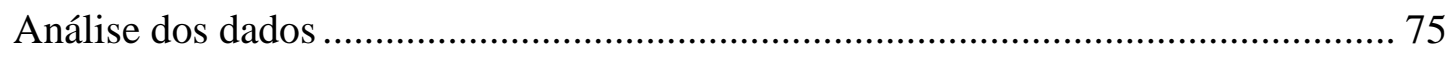

Histórias em vez de casos, narrativas e devires ...................................................... 79

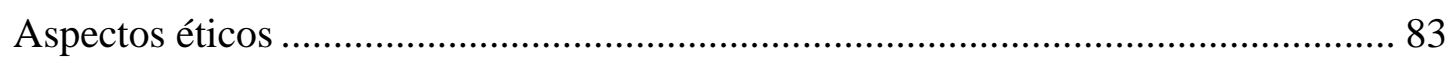

Capítulo 4. TERRITÓRIOS: CAPÃO PECADO, ÂNGELA VERTIGEM................. 84

Hiperperiferia - Afinal, periferia é periferia em qualquer lugar?............................... 87

Capão Redondo: Capão Pecado, Capão Afeto ........................................................... 98

Fundão do Jardim Ângela e a vertigem que se tem............................................... 102

Capítulo 5. TRABALHO, SOCIEDADE, ESTADO E VIDA NUA ........................ 112

[Registro sobre] as drogas na periferia ................................................................ 112

Os meninos que assobiam: dimensões do trabalho no território .............................. 114

[Relatos sobre] a ação policial na periferia …...................................................... 121

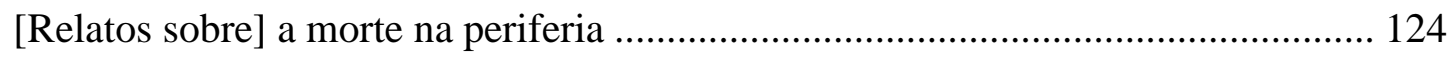


Matar e execrar

Precarizar

Capítulo 6. CARACTERIZAÇÃO DO TRABALHO SOCIOEDUCATIVO: DOS

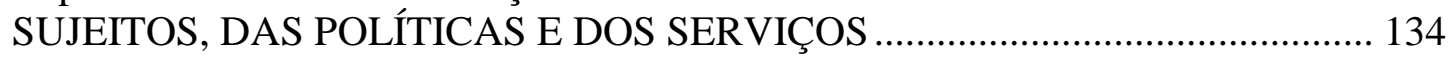

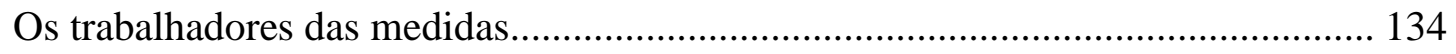

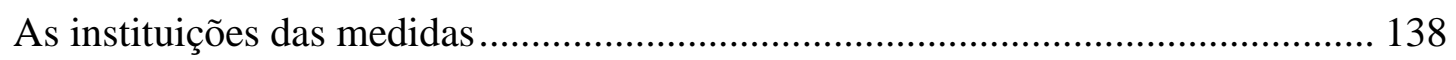

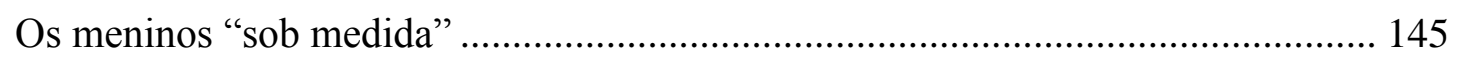

A semântica do "menino" e a semântica do "bandido".............................................. 146

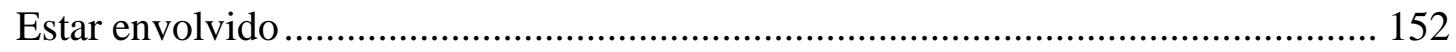

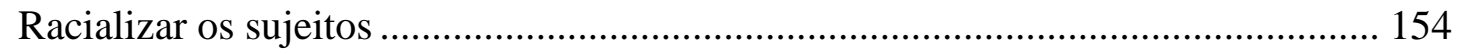

Capítulo 7. POLÍTICAS SOCIAIS, FAMÍLIAS E AFETOS ….............................. 157

Relações familiares, medida socioeducativa e a face afetiva do Estado .................. 158

Trabalho socioeducativo e vínculos sociais, ter com quem contar.......................... 163

A primeira batida do Estado à porta - infracionar para incluir ............................... 168

As mães, os pais, as famílias .............................................................................. 171

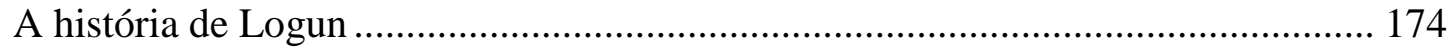

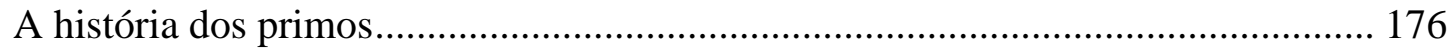

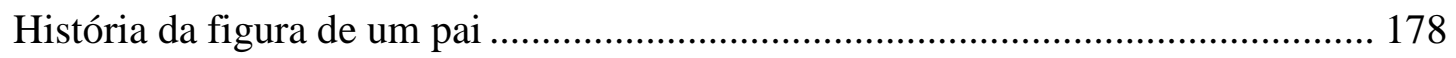

História da família do Pé Torto .......................................................................... 179

A história do contador de histórias .................................................................... 181

História de Aganju e as figuras de autoridade..................................................... 183

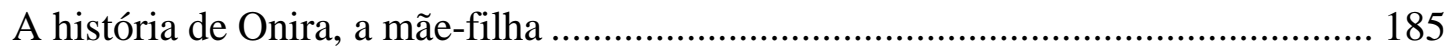

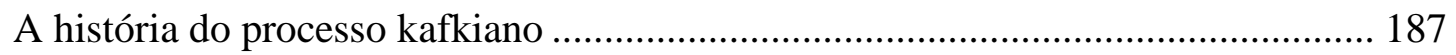

História do filho de Sobá ......................................................................................... 190

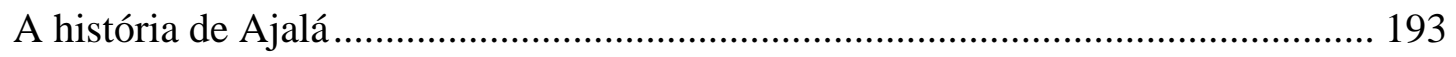

A história de Kokueto e o devir mar.................................................................... 196

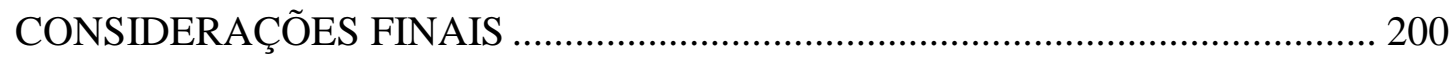

REFERÊNCIAS BIBLIOGRÁFICAS _........................................................... 208

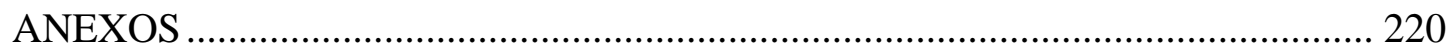




\section{Lista de abreviações e siglas}

AMA Assistência Médica Ambulatorial

CAPS Centro de Atenção Psicossocial

CEU Centro Educacional Unificado

CIEJA Centro Integrado de Educação de Jovens e Adultos

COHAB Conjunto Habitacional (Companhia Metropolitana de Habitação do Estado de São Paulo)

CPTM Companhia Paulista de Trens Metropolitanos

CRAS Centro de Referência de Assistência Social

CREAS Centro de Referência Especializado de Assistência Social

ECA Estatuto da Criança e do Adolescente

FEBEM Fundação Estadual do Bem-Estar do Menor

FUNABEM Fundação Nacional do Bem-Estar do Menor

LA Medida socioeducativa de Liberdade Assistida

$\mathrm{MDH} \quad$ Ministério dos Direitos Humanos

MDS Ministério do Desenvolvimento Social e Combate à Fome

MP Ministério Público

MSE Medida Socioeducativa

OIT Organização Internacional do Trabalho

OMS Organização Mundial da Saúde

ONU Organização das Nações Unidas

OSC Organização da Sociedade Civil

PBF Programa Bolsa Família

PIA Plano Individual de Atendimento

PPCAAM Programa de Proteção à Crianças e Adolescentes Ameaçados de Morte 
PSC Medida socioeducativa de prestação de serviços comunitários

SAICA Serviço de Acolhimento Institucional para Crianças e Adolescentes

SINASE Sistema Nacional de Atendimento Socioeducativo

SMADS Secretaria Municipal de Assistência e Desenvolvimento Social de São Paulo

SMSE/MA Serviço de Medidas Socioeducativas em Meio Aberto

SVS Secretaria Nacional de Vigilância em Saúde

TCLE Termo de Consentimento Livre e Esclarecido

UBS Unidade Básica de Saúde

UI Unidade de Internação

UIP Unidade de Internação Provisória

UNESCO Organização das Nações Unidas para a Educação, a Ciência e Cultura 


\section{Lista de quadro e tabelas}

Quadro 1 Categorias e subcategorias de análise

Tabela 1 Número de jovens em atendimento em medida 17 socioeducativa em meio aberto por região no Município de São Paulo de 2012 a 2014

Tabela 2 Mortalidade por causas externas no Município de São 19 Paulo 2005-2010

Tabela 3 Perfil dos respondentes por sexo/gênero; autodeclaração 73 de cor/raça; idade; região de residência; área de formação; e tempo de atuação no serviço de medidas socioeducativas de meio aberto - São Paulo, 2018

\section{Lista de figuras e gráficos}

Figura 1 Gráfico número de adolescentes em medida 16 socioeducativa por gênero - Brasil, 2014

Figura 2 Gráfico número de adolescentes em medida 17 socioeducativa raça / cor - Brasil, 2014

Figura 3 Mapa da população do Município de São Paulo por raça e 91 cor - São Paulo, 2010

Figura 4 Fluxograma do histórico de ocupação da Zona Sul de São 96 Paulo: do Capão Redondo ao Fundão do Jardim Ângela 


\section{Capítulo 1. INTRODUÇÃ̃}

O pesquisador social, assim como um fotógrafo, é capaz de registrar, a partir de sua perspectiva, um momento de realização do fenômeno que se dedica estudar. Deve, portanto, ter em mente que aquele é um dos momentos de um processo nada estático, que o precede e que ultrapassa sua breve intervenção, assim como o pôr-do-sol está para além do que captura as lentes da fotografia. A metáfora é feita por Claude Bernard (Laville e Dionne, 2008), que afirma que “o observador é o fotógrafo do fenômeno” (p. 34). A entrada em campo - quando há esta modalidade de pesquisa - deve ser uma oportunidade para que o pesquisador apreenda as reverberações sobre os fenômenos a que se dedicou estudar.

Considerando essa premissa, a presente tese é resultado, não somente de trabalho de pesquisa em campo, e seu planejamento em diferentes etapas, como das transformações da sociedade durante o período de realização da pesquisa ${ }^{1}$, e, consequentemente, de inquietações, indagações que restam quando as mesmas estão em curso. A partir dessas indagações, reflexões e (auto)questionamentos, acompanhamos as narrativas institucionais sobre como se constituiriam sujeitos, que são, parece, materializados em discursos e instituições que, a todo momento, redefinem noções sobre o que é a juventude; na particularidade de que os jovens de que ora tratamos

\footnotetext{
${ }^{1}$ No período de finalização deste percurso acadêmico, entre os anos de 2018 a 2019, ocorreram fatos no cenário social e político que, certamente, influenciaram na construção narrativa desta Tese. Entre esses, citamos a execução da deputada federal Marielle Franco, pesquisadora da ação policial em periferias do Rio de Janeiro. A intervenção militar no estado do Rio de Janeiro, e a consequente divulgação pelas mídias de jovens negros executados "por enganos" em ações policialescas. E também o aumento de discursos pelas mídias e também pela sociedade conservadores, fenômeno estudado por Santibanez et. al. (2015). No percurso das etapas de pesquisa, esses acontecimentos reverberaram na entonação dos diálogos estabelecidos com os profissionais entrevistados. Soma-se a isto, o fato de que algumas das organizações com as quais o pesquisador estabeleceu contato afirmavam enfrentar dificuldades de manutenção, devido a um cenário fiscal de desinvestimento no social.
} 
sejam adjetivados por circunstâncias que os inserem nesses aparatos institucionais: o jovem infrator, o "menor", o jovem pobre, periférico e negro, "atendido" pelo sistema de medidas socioeducativas.

$\mathrm{Na}$ compreensão de que o Estado, - este que o insere a partir de seu enquadramento, circunscrição, adjetivação -, exerce propostas e dispõe de um repertório de agenciamento para a vida (e, quiçá para a morte) do jovem que tratamos, tentamos registrar alguns desses percursos, de modo a conduzir as discussões, conforme nos foram narrados por importantes agenciadores do próprio Estado, trabalhadores do sistema de medidas socioeducativas.

Num primeiro momento, esta pesquisa se daria na modalidade de pesquisaintervenção, contando com a participação dos sujeitos (os jovens) na posição dos que produzem as reflexões. Não foi possível, dadas limitações que também tratam dessas transformações da sociedade de que falamos de início e serão abordadas no curso do trabalho. A pesquisa se deu em um tempo de recrudescimento fiscal e desinvestimento em políticas sociais que afetou, portanto, as organizações colaboradoras ao trabalho de campo, assim como, sua disponibilidade de ações no que poderíamos desenvolver.

A pesquisa de campo conta com a interlocução de trabalhadores(as) do sistema de medidas socioeducativas, vinculados a organizações da sociedade civil que prestam serviço ao Estado, colaboradores de tamanha importância para as discussões que seguem tendo como medida seu trabalho na perspectiva de defesa de direitos e promoção das condições sociais, estes falam da sua atuação em territórios periféricos, sobre o acesso dos jovens e das regiões a políticas públicas, e dos desafios que se interpõem no desenvolvimento do trabalho, demonstrando, em alguns momentos, limitações de ação e frustrações. As atividades em campo da pesquisa foram conduzidas 
na Zona Sul do Município de São Paulo, em regiões onde há grande concentração de favelas, altos índices de desigualdade social e violência. Territórios cantados pelas formas de resistências, o que nos permitiu em alguns momentos recorrer a um intercâmbio lírico / literário em meio às discussões teóricas sobre esses territórios. O Fundão do Jardim Ângela e o Capão Redondo, duas regiões que delimitam os processos de expansão urbana em algumas de suas contradições, conforme narrado em tópico específico, como os atravessamentos por interesses de mercado, e alcunhadas pelos registros que produzem o "perigo" e o controle moral (FOUCAULT, 2001; MATSUDA, 2009).

Os resultados da pesquisa direcionam nosso olhar e construção narrativa para as produções a níveis territoriais, o cotidiano nas periferias estudadas em seus contextos de exclusão de acesso a políticas repercute, segundo os relatos, no percurso infracional dos jovens. Além disso, há limitações que são parte do trabalho desenvolvido pelo sistema socioeducativo, dificuldades de interfaces com as demais políticas e serviços; há, por fim, dinâmicas que performam apresentações multifacetadas do Estado, citamos, de um lado, a que defende políticas protetivas sociais, que compõe a garantia de direitos e estabelece vínculos tão potentes que participam nos arranjos familiares, por outro lado, a face punitiva, carregada de discursos morais, propostas e medidas de enrijecimento das políticas.

\section{Organização dos capítulos da tese}

No capítulo inicial, tratamos da apresentação dos elementos estruturantes da pesquisa: apresentação do tema, problemática e hipóteses, objetivos geral e específicos, 
e justificativa e, por fim, buscamos estabelecer uma relação entre a temática e o campo de pesquisa da Saúde Pública.

O capítulo seguinte busca apresentar conceitos importantes na construção teórica do tema, retoma referenciais dos campos da história, das políticas públicas e das ciências sociais acerca do tema, termina com a discussão sobre as abordagens das ciências sociais em torno de juventude e violência.

O capítulo 3 trata do dos cuidados e etapas da construção da pesquisa, aborda o planejamento inicial, descreve como se deu a pesquisa de campo, trata da análise, apresenta a proposta de políticas de narratividade (Passos e Benevides, 2009), e dos aspectos éticos.

O capítulo 4 faz uma apresentação dos territórios do Capão Redondo e do Fundão do Jardim Ângela, relacionando os processos de constituição / ocupação das periferias da Zona Sul de São Paulo, a partir da discussão do conceito de hiperperiferia.

No capítulo 5, são apresentados registros e relatos da pesquisa de campo, e discutimos alguns dos conceitos dali emergentes, como as relações entre as drogas na periferia, mercado, ação policial, a morte na periferia e o conceito de vida nua de Agamben (2007).

O capítulo 6 trata dos relatos dos profissionais sobre o trabalho socioeducativo, suas estratégias de resistência frente às propostas de burocratização, suas articulações em rede, e com o Poder Judiciário, e sobre as práticas discursivas sobre "meninos", "bandidos" e "envolvidos", que circulam na MSE.

O capítulo 7 trata das políticas sociais que garantem o direito à convivência familiar e comunitária, e aborda os vínculos sociais no sistema socioeducativo, 
tensionados pela proposição tardia do Estado na promoção de direitos e garantias, "a primeira batida do Estado à porta", daí é extraído o título deste trabalho.

Finalmente, nas Considerações Finais busca-se resgatar a partir das categorias analisadas no que se relacionam com os objetivos iniciais da pesquisa, destacando alguns pontos, naquilo que se proporia enquanto conclusões, de fato, configuram-se desafios e novas questões.

\section{Apresentação do tema}

No Brasil, a história da infância, adolescência e juventude, enquanto instâncias sociais, é simultaneamente a história das instituições que atendem, registram, prescrevem e configuram essas categorias como atributos com significados na sociedade. Neste panorama histórico, marcado pelas trajetórias institucionais, inscrevese certa fronteira que estabelece os sujeitos enquanto "moleques", "pivetes", "menores" (DEL PRIORE, 2012); sendo que, o que determina tais categorias são, de fato, marcadores de pobreza e, em muitos dos casos, determinantes raciais. Ao longo dos anos, o Estado tratou institucionalizar e reprimir do convívio social e familiar, como suposta "prevenção" aos jovens pobres. Infância e juventude, de acordo com algumas variáveis sociais, como pobreza, gênero e raça, eram compreendidas enquanto "irregularidades", às quais se gerenciava um destino de reclusão em uma rede de equipamentos públicos e privados com tais fins, como as Rodas dos Expostos, Casas de Misericórdia, os orfanatos, e as unidades das Fundações Estaduais do Bem-Estar do Menor (FEBEM), destinadas aos infratores, abandonados e pobres (DEL PRIORE, 2012). 
Presumia-se, até certo período da história brasileira, uma similaridade de conduta e institucionalização que aproxima a criança e o jovem pobre da criança e jovem infratora.

A partir do estabelecimento do Estatuto da Criança e do Adolescente - ECA (BRASIL, 1990), mudanças na compreensão, abordagem e condutas são exigidas sobre adolescentes e jovens em práticas de ato infracional. O jovem em conflito com a lei é uma categoria que desponta no ordenamento legal brasileiro, em substituição ao termo “menor". Ainda nesse sentido, em complementação ao Estatuto, inicia-se em 2006 e consolida-se a partir de 2012, o Sistema Nacional de Atendimento Socioeducativo (SINASE), compreendendo a necessidade de "reinserção" social ${ }^{2}$ dos sujeitos. Ou seja, prerrogativa desta política é trabalhar ações sociais e educativas em conjunto na condução da responsabilização legal do adolescente infrator. Tal premissa interpreta-se em conformidade à prerrogativa de proteção integral, e diz respeito a um compromisso entre família, comunidade e poder público para defesa e garantia de direitos humanos fundamentais de crianças, adolescentes e jovens.

A presente pesquisa procura articular elementos analíticos no campo de estudos das políticas públicas de saúde e assistência social, assim como, das ciências sociais e ciências sociais aplicadas, pensando na adolescência e juventude como objeto discursivo de políticas específicas e de atenção de setores da sociedade e do Estado, bem como de seus representantes institucionais.

O Estatuto da Criança e do Adolescente (1990) e o Estatuto da Juventude (2013) são marcos legais, arautos de uma história recente das políticas públicas no Brasil, um

\footnotetext{
${ }^{2}$ Presume-se pela ideia de "reinserção social" que os sujeitos não se "inseriam" na sociedade previamente à imposição das medidas punitivas, o que cabe pensarmos novamente a ação do Estado ainda aparece supostamente como "corretiva", e não reconhece sua corresponsabilidade na prática infracional do adolescente.
} 
associa-se a discussões pós-reabertura democrática e a compromissos internacionais de Direitos Humanos, o outro a um período de expansão das garantias de direitos sociais e políticos, das ações afirmativas e reparativas e forte participação de movimentos sociais.

Partindo das concepções prescritas nestes mecanismos, existe uma prerrogativa para a constituição subjetiva e cidadã de crianças, adolescentes e jovens. Cabendo respostas dos diferentes setores do poder público, familiar e sócio-comunitário para resguardá-las. Nesta concepção, o ato em conflito com a lei praticado por adolescente denota um desencontro num compromisso coletivo, cuja resposta pelos mecanismos legais acionará os entes sociais envolvidos, tendo em vista a sociabilidade destes sujeitos-cidadãos como parte de seu processo de responsabilização numa repactuação dessas múltiplas instâncias.

Acompanharemos por meio de relatos de profissionais do sistema socioeducativo o atravessamento das políticas públicas em seu acesso ou falta do mesmo, os espaços onde o Estado exerce menos um papel propositivo, ou a despeito, propõe por meio da exclusão, exercendo, contudo, seu direito à violência ${ }^{3}$, um marcador importante para as discussões em torno da juventude. Parece suscitar temas relacionados, como idade penal, maior tempo de penalização das infrações, e ainda, quando surge pautada por veículos midiáticos, consegue obnubilar relevantes questões diretamente relacionadas, como os altos índices de mortalidade, a vitimização promovida por ações policiais, a pobreza e marginalização de parte desta população. Conforme veremos, o número de homicídios entre indivíduos de 15 a 24 anos é maior do que entre outras faixas etárias, sendo que, considerando o Município de São Paulo,

\footnotetext{
${ }^{3}$ DAS e POOLE (2004; 2008) resgatam a noção weberiana de Estado, na qual o aparelho do Estado mantém monopólio do uso legítimo da força na aplicação da ordem.
} 
esta taxa encontra-se diretamente relacionada à ação policial em regiões periféricas (CERQUEIRA et. al., 2017; SANTOS et.al., 2012).

\section{Problemática e hipóteses}

O Brasil, e ainda, especificamente, o Município de São Paulo perpassam mudanças significativas no cenário dos programas e políticas sociais, e, após um período de grande avanço e conquistas de direitos, surgem propostas de desmobilização dos serviços públicos e estratégias nas quais o Estado, coligado a entidades de iniciativa privada, deixa de se responsabilizar pela garantia de direitos de setores específicos da sociedade. No atual contexto, a participação social de certa camada populacional é comprometida, passando pelo enfraquecimento das políticas de educação, trabalho, saúde, assistência social, direitos humanos, entre outras ${ }^{4}$.

Fleury e Ouverney (2008) definem que a noção de cidadania pressupõe a existência de "uma comunidade política nacional, na qual os indivíduos são incluídos, compartilhando um sistema de crenças com relação aos poderes públicos, à própria sociedade e ao conjunto de direitos e deveres que se atribuem aos cidadãos” (p. 2). Podemos pensar, a partir do pressuposto, na formação de lacunas entre o repertório político pós-democrático, desmobilizando a noção de cidadania no que atinge aos jovens de que falamos.

Considerando que há marcadores que acompanham as vidas desses jovens: negros em situação de pobreza e ocupantes de regiões periféricas, ou seja, acumulam

\footnotetext{
${ }^{4}$ O Instituto de Pesquisas Econômicas Aplicadas (IPEA), por meio das notas técnicas 27 e 28, alerta para os impactos do chamado "Novo Regime Fiscal", promulgado por meio da Proposta de Emenda Complementar (PEC) 241 em 2016, para o financiamento e consequentemente na redução dos direitos à saúde e à assistência social no Brasil (PAIVA et. al, 2016; VIEIRA e BENEVIDES, 2016).
} 
exclusões de acesso a direitos, em sua maioria. De modo que temos como questões estruturantes: como se revela nos discursos institucionais do sistema de atendimento socioeducativo os modos de constituição / construção desses sujeitos? Como os cenários decorrentes da violência e da pobreza estruturante, assim como o encarceramento e o racismo, aparecem nos discursos institucionais e são compreendidos ou reproduzidos no cotidiano dos profissionais do sistema socioeducativo?

As hipóteses são neste sentido que exista nesses discursos do sistema de medidas socioeducativas uma compreensão do Estado e da sociedade, menos como um sistema ordenado de garantias, mais como um sistema pró-beneficente, onde as soluções sejam individualizantes para as trajetórias de vida do público em atendimento, particularmente, dos jovens negros moradores de periferias da Zona Sul de São Paulo, circunstanciados pela situação conflitiva com a lei. Por fim, entendemos que encarceramento e/ou violências são as respostas mais frequentes do Estado com relação à população jovem em situação vulnerável, em especial os jovens negros. A pesquisa pretende desvelar, a partir de relatos do trabalho socioeducativo, narrados pelos profissionais do sistema de medidas socioeducativas, como repercutem essas relações.

\section{Objetivos gerais e específicos}

A presente pesquisa tem o seguinte objetivo geral:

Compreender, a partir dos relatos de profissionais do sistema socioeducativo, o acesso aos programas e políticas do Estado pela juventude em conflito com a lei e moradora de periferias, na Zona Sul do Município de São Paulo.

Esta pesquisa conta com os seguintes objetivos específicos: 
I) Discutir, a partir das concepções e descrições feitas por estes profissionais, a respeito das dinâmicas do trabalho, o trânsito das políticas socioeducativas junto às demais políticas, e sua relação com os jovens em atendimento nos serviços no que tratam aos contextos sociais, familiares, e territoriais destes.

II) Levantar, a partir desses relatos, casos e histórias do atendimento socioeducativo, narradas pelos profissionais do sistema socioeducativo, que ofereçam contornos que possibilitem a discussão sobre o acesso / exclusão dos jovens em atendimento socioeducativo às políticas sociais e aos direitos.

\section{Justificativa}

A pesquisa parte originalmente de informações coletadas por diferentes órgãos, que apontam: ao mesmo tempo que alarmantes dados de violência e mortalidade da juventude, paralelamente, um desmonte político-estatal, permeado por ajustamentos fiscais, apresentando como resposta alternativas austeras, promovidas pelos representantes de Estado.

O Brasil, a partir de seu período de reabertura política, confere um reordenamento de gestão metodológica e das práticas no que tange aos fenômenos da infância, adolescência e juventude. Construindo, desta forma, marcos referenciais nestas temáticas, e pactuando junto a organismos internacionais para intervir em indicadores nestas áreas. Cabe dessa maneira, debruçarmo-nos sobre as ofertas de políticas e garantias aos adolescentes e jovens em conflito com a lei, enfatizando que estes são, em sua grande maioria, negros e habitantes de regiões periféricas; pensando ainda que estão suscetíveis a um sistema articulado de exclusões e violências, tendo o Estado como a outra ponta da equação. 
De acordo com levantamento realizado pelo Ministério de Direitos Humanos (2017), o Brasil conta com 24.628 adolescentes e jovens inscritos em serviços do sistema socioeducativo. Somente o Estado de São Paulo conta com 10.211 jovens, quase metade do total brasileiro.

São Paulo é ainda um estado de maior municipalização pelas unidades de atendimento socioeducativo, $25 \%$ dos serviços do Brasil se encontram no estado (Ministério de Direitos Humanos, 2017), garantindo a este Estado um índice de “expertise". Há, portanto, maior investimento nas diferentes modalidades institucionais dedicadas ao cumprimento de medidas socioeducativas.

Cabe, contudo, uma melhor compreensão sobre quem são estes jovens, e quais características compartilham para além da infracionalidade.

Ainda segundo os dados do Levantamento, $95 \%$ dos adolescentes em sistema socioeducativo são do gênero masculino, e 55,7\% se autodeclaram de raça preta ou parda, conforme os critérios do IBGE (Ministério de Direitos Humanos, 2017).

Figura 1: Gráfico número de adolescentes em medida socioeducativa por gênero Brasil, 2014

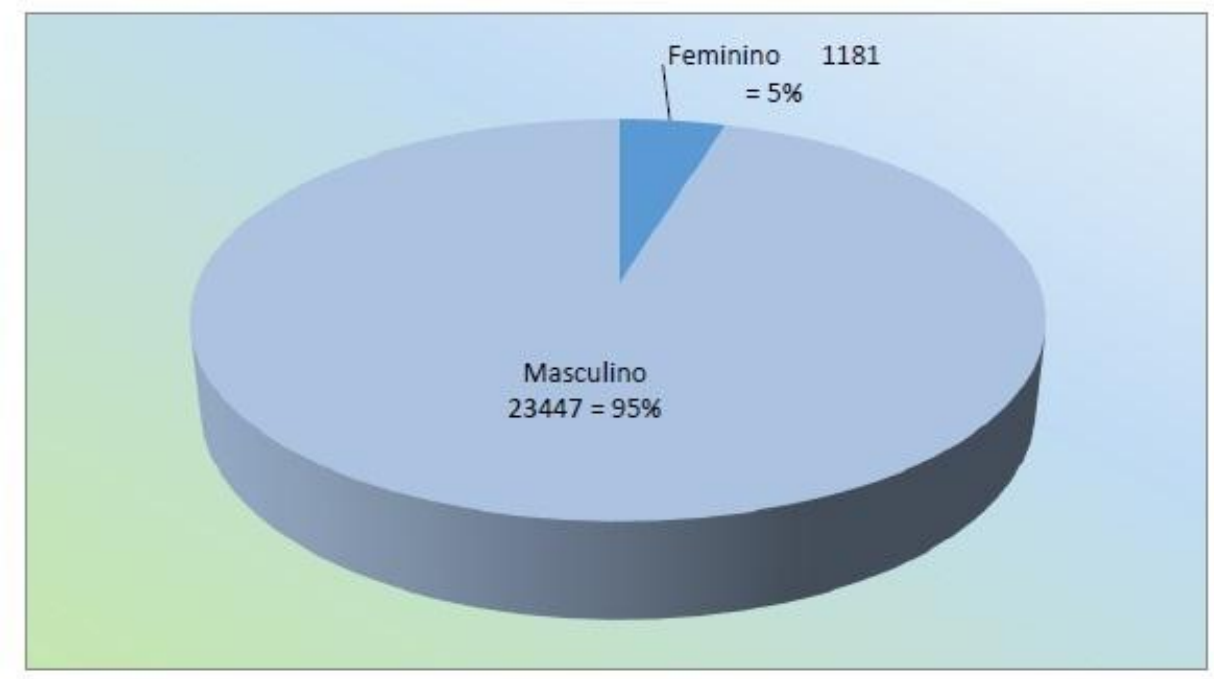

Fonte: Levantamento SINASE. Ministério de Direitos Humanos, 2017. 
Figura 2: Gráfico número de adolescentes em medida socioeducativa raça / cor Brasil, 2014

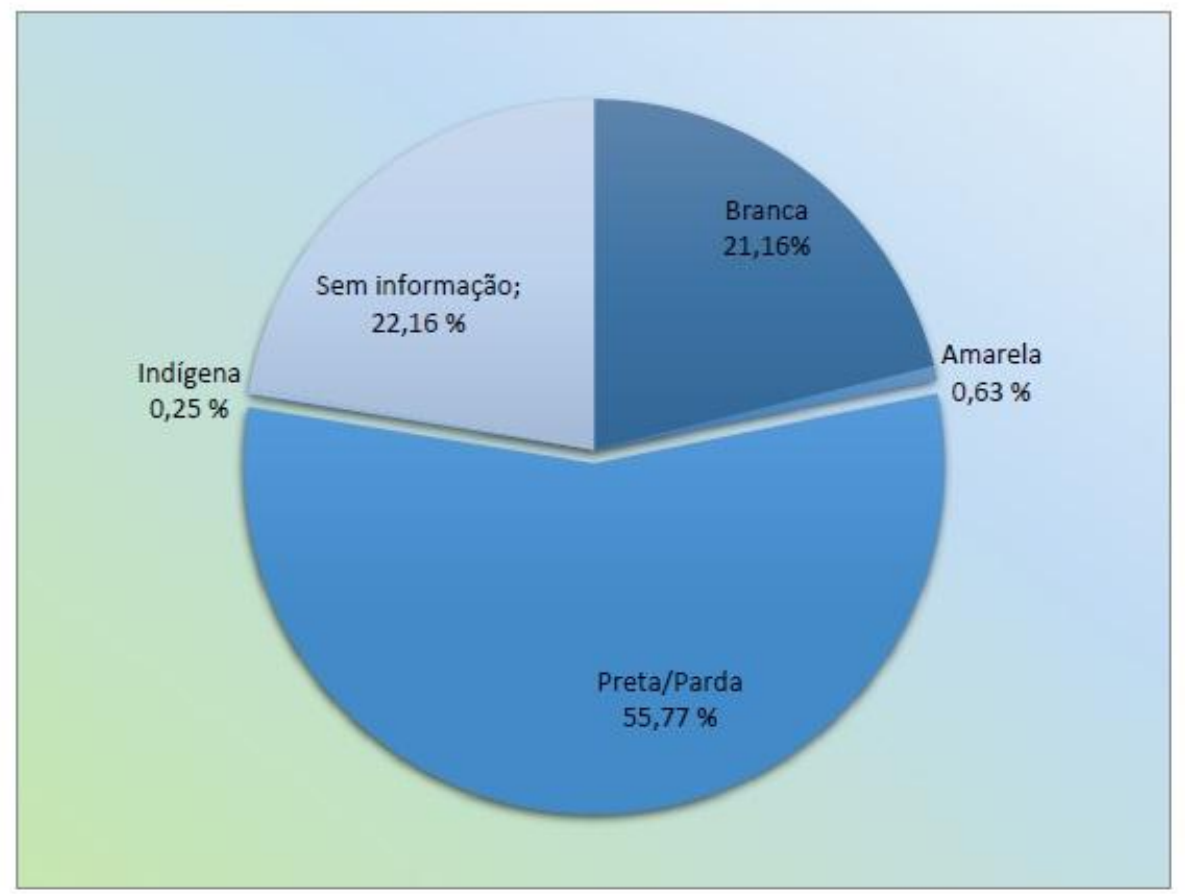

Fonte: Levantamento SINASE. Ministério de Direitos Humanos, 2017.

Verificando os dados específicos do Município de São Paulo, no ano de 2014, havia 7.825 jovens do gênero masculino no sistema de medida socioeducativa municipal (em meio aberto), para 488 do feminino, resultando em 8.313 jovens em cumprimento de medida socioeducativa. As regiões Leste e Sul do município concentram o maior número de jovens identificados em conflito com a lei em atendimento nos serviços de meio aberto.

Tabela 1: Número de jovens em atendimento em medida socioeducativa em meio aberto por região no Município de São Paulo de 2012 a 2014

\begin{tabular}{l|r|r|r}
\hline & 2012 & 2013 & 2014 \\
\hline Centro & 193 & 217 & 213 \\
\hline Leste 1 & 735 & 711 & 756 \\
\hline Leste 2 & 1471 & 1664 & 1825 \\
\hline Norte 1 & 432 & 410 & 486 \\
\hline
\end{tabular}




\begin{tabular}{l|r|r|r}
\hline Norte 2 & 766 & 916 & 1014 \\
\hline Oeste & 182 & 203 & 240 \\
\hline Sul 1 & 414 & 415 & 435 \\
\hline Sul 2 & 1436 & 1407 & 1467 \\
\hline Total da cidade & 5629 & 5942 & 6436 \\
\hline
\end{tabular}

Fonte: Secretaria Municipal de Assistência e Desenvolvimento Social, 2016.

A promulgação do Estatuto da Criança e do Adolescente se deu por meio da Lei Federal 8.069 de 1990. E, a partir da Lei 12.594 de 2012, institui-se o Sistema Nacional de Atendimento em Medida Socioeducativa (SINASE), instrumento que visa, entre outras funções, a integração de informações dos diferentes Estados e Municípios. Com este último, também a informação de raça / cor dos adolescentes e jovens passa a ser informada. Todavia, o documento de 2014 do Município de São Paulo ainda não apresentava estas informações. A subnotificação e desconcentração das fontes de dados ainda uma das dificuldades para identificação e intervenção sobre alguns dos problemas apresentados.

Os dados de mortes por violência apontam aumento de 46,9\% no que tange à população preta e parda brasileira, resultando em 31.320 mortes no ano de 2014 somente. Identificamos, nesta taxa, a população jovem e negra como a mais exposta, tendo um aumento de 17,2\% na taxa de homicídios entre pessoas de 15 a 29 anos (WAISELFISZ, 2016; CERQUEIRA et.al., 2017).

Em sua recente publicação, o IPEA (CERQUEIRA et.al., 2017) identificou a violência policial como um problema a ser mais bem compreendido, enquanto categoria “intervenções legais". E, apesar da alta subnotificação desta, São Paulo aparece novamente com as maiores taxas: 958, em 2014, e 848, em 2015.

A letalidade policial e a vitimização policial que a ela se associa são produtos de um modelo de enfrentamento à violência e 
criminalidade que permanece insulado em sua concepção belicista, que pouco dialoga com a sociedade ou com outros setores da administração pública (CERQUEIRA et.al., 2017: 22).

Este mesmo documento identifica uma tendência crescente de vitimização letal da juventude. Tendo havido no ano de 2015, 31.264 homicídios nesta faixa geracional. Sendo que, $71 \%$ dos homicídios atinge jovens negros do gênero masculino (CERQUEIRA et.al., 2017).

Em análise dos dados específicos ao Município de São Paulo, observa-se ao longo dos anos uma redução na taxa de mortalidade, acompanhada por uma persistência dos dados de vitimização jovem nas regiões periféricas, predominantemente nas regiões Leste e Sul do Município, coincidindo, assim, com as informações disponíveis sobre as regiões de alta infracionalidade juvenil. A tabela 2 apresenta os dados de mortalidade por causas externas (que incluem homicídios, suicídios e mortes em decorrência de acidentes) no período de 2005-2010.

Tabela 2: Mortalidade por causas externas no Município de São Paulo 2005-2010.

\begin{tabular}{|c|c|c|c|c|c|c|c|c|c|c|c|c|}
\hline & \multicolumn{6}{|c|}{ Homens } & \multicolumn{6}{|c|}{ Mulheres } \\
\hline & \multicolumn{3}{|c|}{2005} & \multicolumn{3}{|c|}{2010} & \multicolumn{3}{|c|}{2005} & \multicolumn{3}{|c|}{2010} \\
\hline & $15-19$ & $20-24$ & $25-29$ & $15-19$ & $20-24$ & $25-29$ & $15-19$ & $20-24$ & $25-29$ & $15-19$ & $20-24$ & $25-29$ \\
\hline São Paulo & 407.2 & 571.2 & 486.7 & 275.5 & 400.5 & 336.8 & 49.4 & 54.7 & 48.4 & 49.4 & 46.2 & 43.1 \\
\hline Aricanduva/Formosa/Carrão & 124.7 & 372.5 & 310.7 & 98.9 & 270.6 & 171.1 & 9.7 & 43.2 & 68.8 & 57.5 & 37.5 & 42.4 \\
\hline Butantã & 301.4 & 423.8 & 324.7 & 255.4 & 346.2 & 324.9 & 78.4 & 25.7 & 24.8 & 33.6 & 26.5 & 41.0 \\
\hline Campo Limpo & 458.2 & 711.0 & 521.8 & 370.2 & 504.1 & 413.7 & 76.9 & 75.8 & 48.3 & 64.8 & 51.7 & 34.8 \\
\hline Capela do Socorro & 664.3 & 872.4 & 749.1 & 244.6 & 357.7 & 405.6 & 56.2 & 54.4 & 44.9 & 62.1 & 32.3 & 30.3 \\
\hline Casa Verde/Cachoeirinha & 566.7 & 810.2 & 587.2 & 252.5 & 466.7 & 242.5 & 29.3 & 47.0 & 40.5 & 59.6 & 43.4 & 59.0 \\
\hline Cidade Ademar & 518.9 & 676.8 & 621.8 & 189.1 & 405.7 & 288.3 & 42.5 & 49.3 & 46.1 & 52.2 & 35.2 & 33.7 \\
\hline Cidade Tiradentes & 450.7 & 433.2 & 375.6 & 422.5 & 351.3 & 377.5 & 105.5 & 40.1 & 31.2 & 79.3 & 69.6 & 28.5 \\
\hline Ermelino Matarazzo & 344.4 & 443.5 & 400.1 & 276.5 & 398.8 & 244.3 & 33.1 & 39.9 & 30.6 & 12.6 & 52.3 & 50.0 \\
\hline Freguesia/Brasilândia & 617.3 & 877.7 & 689.3 & 403.6 & 586.5 & 378.4 & 70.6 & 56.3 & 36.3 & 65.6 & 58.7 & 60.7 \\
\hline Guaianases & 334.9 & 510.0 & 406.1 & 230.0 & 393.3 & 394.6 & 37.8 & 22.6 & 31.6 & 31.8 & 76.5 & 23.4 \\
\hline Ipiranga & 286.1 & 540.7 & 362.3 & 314.2 & 321.4 & 277.7 & 33.6 & 54.3 & 23.5 & 37.7 & 30.5 & 35.0 \\
\hline Itaim Paulista & 341.2 & 576.9 & 521.8 & 322.6 & 397.8 & 318.9 & 54.8 & 77.9 & 62.8 & 29.5 & 28.4 & 33.8 \\
\hline Itaquera & 423.9 & 545.3 & 491.0 & 343.4 & 458.7 & 302.4 & 55.7 & 40.1 & 40.8 & 71.9 & 55.5 & 31.3 \\
\hline Jabaquara & 462.2 & 686.1 & 530.8 & 168.9 & 345.6 & 300.9 & 45.1 & 39.0 & 36.8 & 26.0 & 30.5 & 35.4 \\
\hline Jaçanã/Tremembé & 413.8 & 535.8 & 539.0 & 246.2 & 467.3 & 312.4 & 49.0 & 53.7 & 54.6 & 51.2 & 53.6 & 21.7 \\
\hline Lapa & 205.5 & 181.5 & 234.4 & 82.0 & 266.9 & 134.2 & 41.9 & 64.1 & 58.7 & 12.0 & 34.1 & 33.2 \\
\hline M'Boi Mirim & 650.3 & 877.5 & 567.2 & 403.0 & 600.3 & 449.3 & 100.7 & 84.1 & 58.2 & 65.6 & 40.5 & 78.1 \\
\hline Mooca & 257.9 & 305.7 & 308.9 & 124.5 & 253.8 & 310.8 & 26.8 & 21.8 & 35.5 & 29.5 & 43.8 & 38.5 \\
\hline Parelheiros & 734.6 & 992.8 & 899.8 & 257.5 & 598.0 & 491.3 & 77.9 & 99.8 & 118.8 & 60.2 & 31.7 & 61.6 \\
\hline Penha & 311.1 & 384.6 & 394.4 & 283.6 & 343.0 & 309.3 & 20.7 & 36.8 & 59.7 & 36.1 & 34.2 & $49.8-2 y-1$ \\
\hline Perus & 448.7 & 597.9 & 530.7 & 354.9 & 408.5 & 493.4 & 0.0 & 32.2 & 64.0 & 60.3 & 72.1 & 29.0 \\
\hline Pinheiros & 119.2 & 208.8 & 116.7 & 95.4 & 134.0 & 134.6 & 0.0 & 32.6 & 41.5 & 15.5 & 9.3 & 45.0 \\
\hline Pirituba & 344.4 & 491.0 & 439.0 & 300.2 & 354.9 & 402.2 & 27.5 & 81.8 & 50.5 & 35.6 & 56.8 & 56.5 \\
\hline Santana/Tucuruvi & 84.5 & 322.2 & 285.0 & 149.6 & 166.8 & 191.7 & 0.0 & 49.1 & 48.4 & 20.0 & 66.7 & 45.8 \\
\hline Santo Amaro & 205.0 & 391.4 & 416.7 & 146.8 & 209.6 & 290.9 & 0.0 & 10.3 & 48.6 & 30.2 & 23.1 & 9.5 \\
\hline São Mateus & 492.3 & 630.1 & 551.1 & 325.0 & 473.5 & 322.3 & 67.5 & 25.6 & 36.2 & 76.1 & 45.7 & 43.7 \\
\hline São Miguel & 340.4 & 621.5 & 531.1 & 294.2 & 420.2 & 357.4 & 38.7 & 80.8 & 44.7 & 37.3 & 51.0 & 73.6 \\
\hline Sapopemba & 461.9 & 561.9 & 475.5 & 318.2 & 421.0 & 353.6 & 37.6 & 36.4 & 52.2 & 25.6 & 53.2 & 43.3 \\
\hline Sé & 202.3 & 363.5 & 285.3 & 153.2 & 198.5 & 243.8 & 92.7 & 63.7 & 36.2 & 50.5 & 33.5 & 32.2 \\
\hline Vila Maria/Nila Guilherme & 392.1 & 455.7 & 350.4 & 252.5 & 419.6 & 293.6 & 56.1 & 34.9 & 92.7 & 46.9 & 37.2 & 34.8 \\
\hline Vila Mariana & 93.5 & 156.5 & 157.5 & 74.0 & 146.3 & 143.5 & 9.9 & 35.2 & 24.0 & 24.0 & 45.5 & 16.5 \\
\hline Vila Prudente & 322.5 & 358.2 & 343.5 & 197.8 & 473.1 & 376.1 & 10.7 & 56.4 & 27.7 & 24.8 & 39.6 & 26.6 \\
\hline
\end{tabular}

Fonte: UNIVERSIDADE ESTADUAL DE CAMPINAS, 2014. 


\section{Possíveis relações com o campo da saúde pública}

Russo e Carrara (2015) identificam o campo de conhecimento da Saúde Pública e Coletiva com características acadêmico-científicas, historicamente, multidisciplinares. A interlocução junto aos saberes das chamadas Ciências Sociais, Ciências Sociais aplicadas e humanidades não é novidade nas pesquisas em saúde, porém, conforme Ianni (2015), “como campo científico, com circunscrição de objetos próprios e esforços de sistematização normativos e vinculantes, sim”.

Associada à emergência de objetos e métodos de sistematização, Canesqui (1998 e 2008) identifica o aumento de temas de pesquisa "de interesse das Ciências Sociais e Saúde”, como estudos sobre as políticas, sistemas e instituições de saúde, críticas aos modelos de saúde-doença e modelo biomédico, além do aumento significativo de temas relativos aos movimentos sociais, questões de gênero e sexualidades, violência, etc. Russo e Carrara (2015) compreendem que de fato ocorra uma produção que torna os objetos de reflexão como limítrofes, o que indica também a necessidade de mudança da perspectiva dos campos de conhecimento tradicionais das ciências da saúde em sua relação, não só com as ciências sociais e humanas, mas com a sociedade.

Esta preocupação pode ser compreendida, entre outras, pelas discussões acerca do conceito de Transição demográfica e epidemiológica (Duarte, 1992; Duarte e Barreto, 2012) que acompanha mudanças nos padrões de mortalidade e adoecimento das sociedades, mudanças fortemente associadas às transições demográficas e socioeconômicas que constituem o complexo da modernização. $O$ estudo desses modelos indicam diferentes tendências, em curso em diversos países em desenvolvimento, como no Brasil (Duarte, 1992). No país, este é marcado, não somente pelo ressurgimento de doenças infecto-contagiosas, então controladas, como por 
exemplo a sífilis, o aumento de mortalidade por doenças crônicas não-transmissíveis e o aumento significativo dos índices de morte da população por violência (homicídios e suicídios) além de acidentes. Entendemos que as ciências humanas e sociais dispõem de importantes instrumentos de leitura e discussão para essas questões, aumentando as possibilidades interpretativas. Neste trabalho, acompanhamos, a partir dos relatos, histórias que remontam também a essa transição, (como os relatos da história de Onira e a historia do filho de Sobá, no Capítulo 7, embora os demais relatos e histórias também apresentem elementos associados), assim como a diversas outras transformações em perspectiva na sociedade, que apontam para questões e conflitos sociais, e relacionam o campo da saúde e das políticas sociais.

Fleury e Ouverney (2008) tratam da necessidade de compreensão das interfaces da saúde pública com as políticas sociais, e o reconhecimento da saúde pública enquanto política social, por seu potencial de formação de "referenciais éticos e valorativos da vida social", uma vez que políticas de saúde impulsionam "um processo de apropriação, redefinição e produção de significados sociais", produzindo "impactos reais na estrutura social". Discutir as políticas de proteção social é discutir noções de cidadania (Fleury e Ouverney, 2008). 


\section{Capítulo 2. ASPECTOS HISTÓRICOS E PRODUÇÃO DICURSIVA ACERCA DO TEMA DE PESQUISA}

Este tópico trata da construção do tema da pesquisa, que emaranha conceitos, mobiliza marcadores e categorias sociais, que nos embaraçam conforme acompanhamos as falas de nossos interlocutores, profissionais atuantes no sistema de medida socioeducativa, ora tratamos de questões sociais pertinentes à juventude, outrora falamos do Estado, assim como, das instituições, agentes e saberes que produzem essas noções.

Apresentamos neste capítulo autores e autoras principalmente dos campos das Ciências Humanas e Sociais, Ciências Sociais aplicadas, e do campo da Saúde, no anseio de perseguir o tema a partir daquilo que esses saberes produzem. Tratamos também de apresentar alguns dos referenciais teóricos, conceitos e noções que vão se desenrolar nos capítulos seguintes deste trabalho.

Iniciamos a discussão apresentando os aspectos históricos sociais e políticos do tema, na sequência, apresentamos brevemente autores, autoras e os principais conceitos que contribuirão com as discussões desenvolvidas nos tópicos seguintes neste trabalho.

\section{História social da infância e adolescência}

Philippe Ariés (1986) é responsável por um levantamento analítico pioneiro nos registros sobre a infância. Sua análise inicia a partir da compreensão das "idades da vida" em diferentes conjunturas históricas entre as Idades Média e Moderna na Europa. O entendimento e a produção discursiva acerca desse conceito é um dos mais relevantes argumentos em sua obra, uma vez que o autor localiza os momentos históricos em que 
se identifica a importância de se estabelecer, compreender e tornar em teorias a respeito das etapas de divisão da vida.

A história da infância estabelecida por Ariés parte de duas principais premissas (LIMA, 1984; ARIÉS, 1986). Sendo a primeira que a socialização da criança acontecia até a Idade Média fora da família. Ou seja, neste período histórico da Europa, a socialização da criança se dava ao misturar-se às atividades do mundo adulto, como as práticas laborais coletivas, por exemplo. A relação afetiva com a criança ocorria de maneira pública, nas festividades e cerimônias coletivas. O "sentimento de infância" é um objeto difuso, de pouco interesse para as sociedades europeias de então.

A premissa seguinte é que a infância assume um lugar de destaque na sociedade a partir da Modernidade, por meio das instituições da escola e da família. O autor indica que isto se deu num constante movimento de moralização cristã na Europa do século XVII. O estabelecimento da vida escolar garante uma separação mais adequada da criança dos adultos, por meio da educação, e com o desenvolvimento das teorias pedagógicas, busca-se o preparo das crianças à vida adulta e sua constituição como cidadãos (ANDRADE, 2010: 58). À família, a partir daí, exigem-se certas responsabilidades com as crianças, especialmente no que diz respeito à garantia de educação e afetividade às mesmas. Sendo ainda prescrito um novo planejamento arquitetônico que preparasse as casas, de modo a conceber a intimidade e privatização dos espaços domésticos. Vida adulta e a "condição" de infância agora se tornam moralmente e espacialmente distintas.

Sandra Corazza (2012) destaca que o conceito de "criança" ou "infância" não era objeto de interesse discursivo até a Modernidade. De modo que as explicações que 
dão conta destes fenômenos apontam sua construção social na Europa a partir do século XVIII. Ariés acompanha a formação de vocábulos para distinguir a infância das demais etapas da vida. Sendo que a primeira infância passa a ser denominada na França somente a partir do século XIX (CORAZZA, 2002).

A compreensão acerca da adolescência ainda demoraria a se formar no pensamento europeu, segundo o autor. Para Ariés, o primeiro adolescente moderno típico foi o personagem Siegfried da peça de Wagner, que, em sua música, buscou inspirar "pureza provisória”, "força física”, "naturismo", "espontaneidade" e "alegria de viver" (ARIÉS, 1986: 46). Na Alemanha de Wagner e na França, teria origem a noção de adolescência e juventude, tornando-se tema artístico e literário e preocupação moral e política.

A juventude apareceu como depositária de valores novos, capazes de reavivar uma sociedade velha e esclerosada. Havia-se experimentado um sentimento semelhante no período romântico, mas sem uma referência tão precisa a uma classe de idade (ARIÉS, 1986: 47).

Após a Grande Guerra de 1914, o "sentimento de juventude" se consagraria, tornando o século XX no "século da adolescência" (Id, 1986: 48).

A consciência da juventude começou como um sentimento comum dos ex-combatentes, e esse sentimento podia ser encontrado em todos os países beligerantes, até mesmo na América de Dos Passos. Daí em diante, a adolescência se expandiria, empurrando a infância para trás e a idade adulta para a frente (ARIÉS, 1986: 47).

Coutinho (2005 e 2009) entende que esse movimento se intensifica em meados do século XX, em meio ao surgimento de movimentos libertários, e a propagação da contracultura estadunidense nos demais países. Esta autora identifica a noção de adolescência à uma intensa difusão de valores como autonomia, liberdade e individualismo. 


\section{Definições de adolescência}

Vimos que, com Ariés (1986), o advento da Modernidade consolida as tentativas de demarcações das "idades da vida" e sua passagem de um modo considerado mais popular ao saber científico. Coutinho (2009) ressalta que os estudos no âmbito acadêmico-científico das áreas da Psicologia e da Educação são fundamentais para o estabelecimento de um aparato teórico discursivo sobre a adolescência.

Em 1904, Stanley Hall publica Adolescência, um livro de caráter enciclopédico (dois volumes), marcado por uma leitura psicológica do fenômeno. Em 1905, Freud escreve os Três ensaios sobre a sexualidade infantil, nos quais se insere o escrito sobre "As transformações da puberdade" e, em 1919, a revista L'Education, dedica um número à, até então, inédita "crise da adolescência" (COUTINHO, 2009: 137).

A adolescência é descrita por essas áreas como uma etapa do desenvolvimento humano, com delimitadas especificidades. Pappalia e Feldman em sua obra Desenvolvimento Humano (2013) apresentam a adolescência como uma etapa onde os indicadores científicos apontam deflagrar a "busca por identidade", "determinação da orientação sexual", mudanças no relacionamento familiar, e a possível emergência de comportamentos antissociais. O psicanalista Erikson é um dos responsáveis por essa teorização da adolescência, segundo o qual o desenvolvimento dá-se por meio de "crises" psicossociais, de modo que a "confusão de identidade" é a crise própria da adolescência. Ainda de acordo com este autor, há uma moratória psicossocial que permite aos adolescentes buscarem compromissos e uma fidelização ideológica nesta etapa de suas vidas. Já, conforme o psicólogo James Marcia, ainda na adolescência é esperado o desenvolvimento de até quatro diferentes estágios da identidade (PAPPALIA e FELDMAN, 2013: 423).

Numa perspectiva mais organicista, Pappalia e Feldman (2013) defendem que as mudanças corporais que se desenvolvem na puberdade afetam os sujeitos também em 
termos psicológicos. As autoras relembram que as sociedades tradicionais costumam ter rituais de passagem para a comunidade adulta e, entre seus membros, tais mudanças geralmente se ligam à puberdade. As autoras, no entanto, concordam que a construção social da adolescência enquanto fenômeno que remete ao século XX. Porém, em seu entendimento, trata-se "hoje" de um "fenômeno global" (p. 386).

Na maior parte do mundo, a entrada na vida adulta leva mais tempo e é menos definida do que no passado. A puberdade começa mais cedo do que antes; e o início da vida profissional ocorre mais tarde, frequentemente requerendo períodos mais longos de educação ou treinamento profissional para que o indivíduo possa assumir as responsabilidades da vida adulta. $\mathrm{O}$ casamento com suas responsabilidades associadas tipicamente começa mais tarde também. Os adolescentes passam grande parte de seu tempo em seu próprio mundo, amplamente separado do mundo dos adultos (PAPPALIA e FELDMAN, 2013: 386).

Se Pappalia e Feldman argumentam haver uma "globalização da adolescência" em curso (p. 388), reproduzindo o fenômeno nos diferentes contextos de sociedades, de modo a inserir-se e alterar até mesmo as diversas tradições. Coutinho (2005 e 2009), por outro lado, destaca que a adolescência, enquanto um produto tão recente da sociedade ocidental, ligada, sobretudo, a propostas individualistas, onde "cada indivíduo é responsável pela sua trajetória de vida e pelo lugar que ocupará no socius" (COUTINHO, 2009: 138), enquanto fenômeno cuja origem é tão recente e contextualizada, incorremos no risco de chegar a definições "naturalizantes e universalizantes da teorização acerca da adolescência” (p. 139). Afirma a autora (2005) que o conceito de adolescência no Ocidente liga-se a um ideal cultural de "hiperindividualismo", de modo que remete à "pulverização dos grandes ideais sociais que dão consistência ao laço social". Argumenta Coutinho que a "errância" subjetiva, própria da adolescência ocorre na tentativa de fixação de um lugar de si diante do outro na cultura (COUTINHO, 2005; OLIVEIRA, 2010). 
Para a autora, o conceito de adolescência, apesar de sua difusão globalizante, só tem sentido em um contexto onde a cada indivíduo é delegada a responsabilidade de administrar seu próprio destino, ou seja, ligado a uma concepção ideológica de estratégias individualizantes (COUTINHO, 2005).

\section{As crianças negras e as crianças pobres têm uma História diferente?}

Rizzini e Bush (2006) destacam que os aspectos da globalização expõem as desigualdades culturais e econômicas entre os países (p. 79-80). No entanto, o Brasil é um caso de especificidades para além do cenário global, mas desigualdades intrínsecas decorrentes de seus processos históricos sociais e raciais de desenvolvimento assimétrico.

Embora se busque o registro historiográfico da infância e da juventude a partir de referenciais diversos, infância e juventude na Idade Antiga, infância e juventude na transição da Idade Média à Modernidade, registros eurocêntricos de infância e juventude, e mesmo no Brasil, cabe destacar a necessidade de se levar em conta especificidades diversas, relativas aos processos sociais estruturantes. No caso brasileiro, crianças de origens europeias, indígenas e negras vivenciaram e, ainda nos dias de hoje, vivenciam significantes e sentidos diferentes acerca das noções de infância, adolescência e juventude. Del Priore (2012) destaca o marco da educação jesuíta como uma das primeiras divisões da história da infância no Brasil Colônia. A educação cristã era destinada a parte dos indígenas nos processos de catequese e aldeamentos missionários. 
A instituição da educação pública, que ocorre em 1856, é um marco importante no registro da infância no país. Segundo Del Priore (2012), os filhos de uma pequena elite recebiam educação particular, já a escola pública reservava vagas aos jovens que demonstrassem "distinção e capacidade". Ao mesmo tempo, proibia o acesso de crianças escravizadas, apresentando pequeno número de negros libertos e pardos. Afirma Del Priore que "a desigualdade social e racial inscrevia-se, portanto, nas origens do ensino público que não era pra todos" (p. 237).

Na história da juventude negra no Brasil, entre as diversas instituições a que remete, a escravidão é, certamente, uma das de maior impacto. No século XIX, na transição entre os períodos de escravismo e pós-abolição, a proposta para a juventude pobre (e, principalmente a negra) não é a educação como finalidade per se, mas sim seu aproveitamento em sua produtividade ocupacional.

\section{Meninice e infância na história social do Brasil}

A obra de Gilberto Freyre tem uma perspectiva de destaque para a noção de "meninice" no Brasil, tal noção seria utilizada como perspectiva para compreensão da sociedade brasileira. Conforme sua análise, a sociedade escravocrata brasileira, além da distinção fundamental, marcada por Freyre, em suas principais obras, entre brancos e escravos, apresentava ainda outra oposição entre o mundo adulto e o infantil. Para Freyre, a vivência da infância era demasiadamente abreviada no Brasil, tendo como marcos a diminuição dos brinquedos. Ainda conforme o autor, vemos que as crianças brancas, mesmo que diferentemente do povo negro, sofriam também castigos físicos em excesso, sendo comum sua execução por todo seu circuito social, composto além de sua 
família, por padres, padrinhos e madrinhas e professores (OLIVEIRA, 2015: 215; FREYRE, 2003).

Ao desenvolver-se o conceito de infância, essa tendência ao exercício de violência física vai diminuindo ao longo dos anos. Esse "gosto de judiar" repercutia, porém, em um sadismo implícito como marca daquela sociedade, tendo direta observação na relação entre as crianças brancas e os negros de seu convívio, como escravos e empregados e os "moleques", que lhe serviam de "brinquedo" (FREYRE, 2003: 419). “Aquele mórbido deleite em ser mau [...] é de todo menino brasileiro atingido pelo sistema escravocrata" (FREYRE, 2003; OLIVEIRA, 2015).

\section{História dos moleques, dos pivetes e dos vagabundos}

O que se percebe na transição da juventude negra neste período é sua constituição, inicialmente, enquanto "moleque". A “condição" supostamente análoga à adolescência de um jovem branco, para um jovem negro no século XVIII era a chamada “molecagem”. Termo diretamente ligado à sua condição de escravizado.

O início de seu trabalho doméstico era em média aos 04 anos de idade, acompanhando seus pais; aos 12 já possuía ofícios e tarefas as quais atrelava-se funcionalmente, "roça", "mucama”, isto é, nesta idade já apresentavam redobrado “valor de mercado" (DEL PRIORE, 2012:245). "Trabalho ao longo da infância, sem tempo para a ideia que comumente associamos à infância, a da brincadeira e do riso, era o lema perverso da escravidão" (p. 246).

(Gilberto Freyre) refere-se a "meninos e adolescentes que sob os nomes técnicos de molequinhos, moleques, crias e molecões", encontram-se, tantas vezes nas faturas de carregamentos de escravos e nos anúncios de vendas e fugas (DEL PRIORE, 2012:246). 
Freyre em suas principais obras destaca a presença de "vultos" de pessoas negras que sucediam o convívio das relações cotidianas dos brasileiros brancos no sistema escravista. Entre estes, interessa-nos o "vulto do moleque companheiro de brinquedo". As crianças brancas, ao aprenderem a andar, "ganhavam" de companhia crianças escravizadas de seu mesmo gênero e idade: "moleques" ou "molecas". Muitas vezes, sua função, para além da companhia para brincadeiras, era a atualização das relações onde a violência física e o sadismo prosperavam seu legado. Sobre tais moleques, o autor dizia: "crescem juntos e o escravo torna-se o objeto sobre o qual o menino exerce os seus caprichos; empregam-no em tudo e além disso incorre sempre em censura e em punição" (FREYRE, 2003: 419).

Com o fim do período da escravização negra, no campo, o trabalho nas lavouras de canas empregou os adolescentes das senzalas nas fazendas. Nas cidades, o "jornal dos filhos", isto é, jovens que viviam em famílias monoparentais, (predominantemente, famílias negras), que trabalhavam fora para ajudar suas mães no sustento de suas casas, exercendo atividades como engraxar sapatos ou vender jornais.

Instituições de ensino profissionalizante privadas começam a surgir, muitas ligadas a frentes católicas, consistiam na oferta de oficinas de trabalhos manuais, e abrem acesso e/ou abrigo a crianças negras, além de atender meninos "desocupados" (isto é, crianças e jovens pobres que vagavam pelas ruas) e filhos libertos de escravizadas, servindo para "disciplinar os libertos". Nestes institutos, alguns chamados de Asilos, "as crianças negras aprendiam leitura, escrita, aritmética, mas aprendiam, sobretudo, o trabalho manual capaz de reproduzir, por si só, a desigualdade social na qual estavam mergulhadas" (DEL PRIORE, 2012: 237). 
Não havendo uma política educacional de Estado, Del Priore (2012) ressalta que o miserabilismo das famílias negras tende a se agravar na transição urbana após o período da instalação da República (p. 247).

Segundo a análise de Passetti (1999), a proclamação da República deu-se acompanhada de promessas nacionalistas de desenvolvimento, mas o que se viu foi um "século no qual muitas crianças e jovens experimentaram crueldades imagináveis", perpetradas, como descreve o autor, "no próprio núcleo familiar, nas escolas, nas fábricas e escritórios, nos confrontos entre gangues, nos internatos ou nas ruas entre traficantes e policiais" (p. 347). Indicando o autor que este cenário ainda traz consequências nas concepções de infância, adolescência e juventude da sociedade brasileira contemporânea. A passagem entre os séculos XIX e XX acompanhou uma crescente urbanização no Brasil, este processo, contudo, resultou nos diferentes estados e cidades a produção de subúrbios, "casas de aluguel, quartos de cortiços, barracos em favelas ou construções clandestinas" (PASSETTI, 1999).

O Estado brasileiro em transição urbana traz consigo correntes ideológicas que prescrevem administrar e regular sobre essas desigualdades que vão se tornando cada vez mais evidentes, de modo que se consolida um Estado de intervenção sobre os pobres, alegando prevenção e continência da violência, criminalidade ou da delinquência latente neste setor populacional.

A difusão da ideia de que a falta de família estruturada gestou os criminosos comuns e os ativistas políticos, também considerados criminosos, fez com que o Estado passasse a chamar para si as tarefas de educação, saúde e punição para crianças e adolescentes (PASSETTI, 1999: 348).

Até o século XIX no Brasil, houve um grande aumento do abandono de crianças, de acordo com Passetti, este fator se associava às dificuldades de muitas famílias em sua manutenção econômica. Nos centros urbanos, com o crescimento da industrialização, 
iniciaram-se em 1917 greves e reinvindicações de movimentos trabalhistas. O trabalho infantil era pauta desses movimentos, uma vez que era comum a participação de crianças e jovens nas fábricas para garantir o subsídio das famílias de trabalhadores.

Assim, nos primeiros anos da República, inicia-se um aprimoramento dos aparatos jurídicos, e iniciam-se as primeiras estatísticas criminais. Estas revelam que os chamados "pivettes", crianças e jovens que ocupavam as ruas em expedientes de trabalhos informais ou de esmolas, eram responsáveis por diversos delitos, principalmente furtos, e protagonizavam cenas de violência e vadiagem. Como sabemos, esses jovens, em sua maioria negros, recorriam ao "expediente da rua" para o auxílio de suas mães e sustento aos lares (DEL PRIORE, 2012: 248).

Na passagem entre os séculos XIX e XX, perspectivas teóricas higienistas acompanham o conhecimento científico no Brasil, destacam-se, sobretudo, os saberes médico e judiciário. À infância no Brasil em transição urbana cabe a "intervenção" e "amparo", de modo que surge a categoria "menor", compreendida com a finalidade interventiva e estabelecimento de condutas de institucionalização por ações sistematizadas do Estado.

As primeiras décadas do Brasil República se encerram com um investimento sobre a juventude pobre, vista como "potencialmente abandonada e perigosa, a ser atendida pelo Estado", conforme identifica Passetti (1999). De modo que os governos priorizam a partir daí nas políticas de educação de modo a: i) integrar jovens pobres ao mercado de trabalho em ofícios e profissões consideradas mais manuais e menos remuneradas; ii) evitar sua politização e associação ao pensamento anarquista e, posteriormente, socialista. Deste modo, a educação oferecida pelos órgãos do Estado aos pobres e abandonados tratava de assegurar o controle e a direção política 
centralizadora, além de assegurar sua manutenção no sistema econômico, sob pretexto de prevenir sua delinquência (supostamente, latente). Conforme o autor, "escola e internato", e as demais instituições, passam a ser fundamentais (PASSETTI, 1999: 355).

No Brasil, como observamos, a história da infância liga-se a suas instituições, o interesse em compreender a condição de "menoridade" esteve acompanhado, desde tempos, a uma perspectiva de controle e prevenção à vagabundagem e à delinquência, produzindo práticas de criminalização das infâncias e juventudes, e condutas de asilamento, aprisionamento e institucionalização, sobretudo, quando se tratam das pobres e pretas.

Moleques, menores, pivetes e vagabundos são sujeitos, em seus tempos, de processos políticos e econômicos que ocorrem violenta e desordenadamente e resultam em exploração e desigualdades. Processo ou projeto sócio-histórico de empobrecimento de uma categoria social específica e de determinados sujeitos de mesma origem racial, em nome da expansão excludente do país. Estes sujeitos, com o avanço das disciplinas jurídicas e políticas públicas, passam a ser denominados como os adolescentes e jovens, que circularão por outras instituições e serão atendidos por outras políticas, do reformatório, passando pelas FEBEM, até sua atual adscrição no sistema socioeducativo. 


\section{Políticas sociais de infância, adolescência e juventude no Brasil}

A literatura acerca do histórico das políticas públicas para adolescentes e jovens em conflito com a lei costuma separar seus períodos por "doutrinas", terminologia utilizada pelos saberes jurídicos. Isto aponta que, enquanto convenções sociais, infância, adolescência e juventude, terão diferentes perspectivas conforme os olhares da sociedade e do Estado se transformam; particularmente, a partir de seus mecanismos e institutos reguladores, com ênfase nos saberes e discursos acerca da temática, tendo o campo do Direito grande relevância na abordagem do tema.

Desse modo, dividem-se os períodos históricos referentes à condução das políticas sociais, e também a perspectiva e entendimento social sobre o tema, com principal destaque nesta leitura às Doutrinas da Irregularidade e a Doutrina da Proteção Integral, sendo que, nesta última, apresenta-se o modelo vigente do Estatuto da Criança e do Adolescente (1990) e do Sistema Nacional de Atendimento Socioeducativo (2012).

\section{Brasil Colônia e Império - dispositivos e instituições, as Rodas dos Expostos}

Durante o período colonial, crianças a partir dos 07 anos de idade respondiam penalmente, sendo eximidos das penas capitais e podendo receber redução de suas penas. Neste período, considerava-se "jovem adulto" a etapa geracional entre 17 a 21 anos, e a partir desta idade a imputabilidade penal era considerada plena (RIZZINI, 2006 ; SILVA, 2011). Com o estabelecimento do período imperial no Brasil, com o Código Criminal, a imputabilidade penal plena é reduzida e inicia aos 14 anos de idade.

Percebe-se aqui que a história das políticas para infância adolescência e juventude tem direta relação com suas instituições. Entre os períodos colonial e imperial 
no Brasil, há a implantação de equipamentos e serviços reguladores, como os institutos voltados à “correção" de jovens infratores e ao abrigamento de órfãos e abandonados.

"Enjeitados", "deserdados da sorte ou fortuna", "criança infeliz" foram denominações comuns, referindo-se a estas crianças. Para elas destinaram-se as Casas da Roda ou Casa dos Expostos. Criadas em 1726 (a da Bahia), em 1738 (a do Rio de Janeiro), em 1825 (a de São Paulo), em 1831 (a de Minas Gerais), só foram desativadas, como mecanismo de recolhimento de recém-nascidos articulado à antiga caridade, no início do nosso século. (ARANTES, 2008).

Dentre os dispositivos-instituições, um dos mais conhecidos são as chamadas Rodas dos Expostos. "A Roda dos Expostos visava orientar a população pobre no intuito de transformá-la em classe trabalhadora e afastá-la da camada considerada perigosa, geralmente envolvida com a prostituição e a vadiagem" (SILVA, 2011:35). As crianças abandonadas eram futuramente encaminhadas a trabalhos produtivos forçados. Venâncio (1999) fala de marcadores raciais que acompanhavam as crianças, majoritariamente, filhas de negros ou mestiços, consideradas de "raças degeneradas", eram acolhidas por essas "rodas".

A extinção desses dispositivos, pautada por movimentos médico-higienistas, acompanha marcos transicionais das técnicas assistenciais e mecanismos legislativos e judiciais. Infância e juventude passam "de objeto da caridade para objeto de políticas públicas" (ARANTES, 2008). A investida de diferentes saberes, mas especialmente da medicina e do direito, propõe uma maior racionalidade assistencial nas tecnologias de vida de crianças e adolescentes, porém, como observa Arantes (2008) "a pretendida racionalização da assistência, longe de concorrer para a mudança nas condições concretas de vida da criança, constituiu-se muito mais em uma estratégia de criminalização e medicalização da pobreza” (p. 152). 


\section{Situação Irregular e Direito do Menor}

Sousa (2015) destaca que os Códigos Penais de 1830 (Império) e 1890 (República) compartilhavam o entendimento sobre o discernimento do "menor" acerca de seus atos criminais. Este era apurado em juízo e orientava a condução da sentença. Se se entendesse que houve "discernimento" de suas ações, em contexto de prática infracional, supostamente receberia penalidade de acordo com tal delito; não havendo discernimento, penalidade reduzida.

O Estado assume em definitivo sua agência sobre a infância e juventude especialmente a partir de fins do século XIX, onde "prevenção, educação, recuperação e repressão" se tornam estratégias para lidar com a categoria "infância", remetida principalmente às crianças de estratos sociais mais baixos (SILVA, 2011).

Ainda conforme Sousa (2015), o processo de urbanização e modernização do Estado brasileiro produz deslocamento da atenção do Estado para além do controle e da disciplina dos trabalhadores, cabe ao poder público e à agência policialesca preocuparse com certos "perigos morais", então representados por prostitutas, ébrios, vagabundos, libertinos, mas também por "crianças, adolescentes e jovens desocupados pelas ruas" (p. 17).

Em 1899 fora criada a Escola Correcional XV de Novembro no Rio de Janeiro; em 1902, o Instituto Disciplinar em São Paulo; em 1909, o Instituto João Pinheiro em Belo Horizonte. Tais instituições demarcam uma lógica tutelar de condução da infância e adolescência nas camadas pobres da sociedade, sendo a internação institucional uma proposta de tratar o alegado desvio e preparar o jovem para uma futura "readequação" enquanto mão-de-obra (SOUSA, 2015). 
O Brasil passa a acompanhar a movimentação de diversos países nas políticas sobre a juventude. Em 1911, acontecia em Paris o Congresso Internacional de Menores e, em 1924, a Liga das Nações adotava a Declaração de Gênova dos Direitos das Crianças. Mas o país seguia principalmente a influência estadunidense, onde, em 1899 surgira a primeira instituição de Tribunal Juvenil. Conforme Sousa (2015), o Brasil fundamentava sua legislação em paradigmas então compartilhados por organismos internacionais do Ocidente, num "caráter tutelar decorrente do binômio carência/delinquência, criando a categoria jurídica denominada menores" (p. 19).

No ano de 1923, o sistema de Justiça brasileiro instituiu a figura do Juiz de Menores, tendo sido Mello Mattos o primeiro a ocupar a cadeira de juiz de infância e juventude. Em 1927, instituía-se o Código de Menores do Brasil, conhecido como Código Mello Mattos, cuja função era regular sobre as infrações praticadas por "menores", e ainda observar assistência e proteção aos menores considerados “abandonados" (SILVA, 2011).

Arantes (2008) chama a atenção para as categorias produzidas a partir de então. "Menor" e "criança" são sujeitos distintos para o direito nesta concepção. O primeiro é submetido a protocolos tutelares a partir das políticas chamadas de Doutrina da Situação Irregular ou Doutrina de Irregularidade. Por outro lado, “crianças” eram os sujeitos ligados às famílias de classe média e alta. Aos "menores" abandonados, deficientes, infratores, entre outros, cabia passivelmente a intervenção do Estado, em conformidade ao ordenamento jurídico vigente. Segundo Rodrigues (2015), enquanto as classes mais altas da sociedade estavam cooptadas pela lógica higienista, promovida em discursos médicos e pedagógicos, “os segmentos mais pobres da população receberão as intervenções e controles dos aparatos jurídicos e policiais” (p. 49). 
Destaca-se que essa produção jurídico-discursiva não conduzia à crítica de um sistema das desigualdades ali impostas, e, sobretudo, suas práticas resultaram num aprofundamento de estigmas por meio de soluções culpabilizantes / individualizantes, de modo a endereçar as irregularidades denunciadas às famílias, ou às próprias crianças e adolescentes.

Assim, através de um artifício que transformou pobreza em irregularidade jurídica, a criança pobre passou a ser definida como "menor carente" ou "menor infrator" (hipóteses de situação irregular) e, através de um conteúdo médico-psico-social atribuído a estes menores, as medidas (ou penas) para sanar tal situação, dita de irregularidade, foram deslocadas para os próprios menores, e não para a situação (ARANTES, 2008: 153).

No ano de 1940, no Brasil se consolidava uma Justiça de Menores, com os postos de Juiz e de Curador de Menores. E, a partir desta sistematização, instituições do Estado e instituições privadas tratariam do tema, cabendo ao Serviço Nacional de Assistência a Menores (SAM), fundado em 1941, ocupar-se da ordem social. Este sistema adota uma avaliação da periculosidade da personalidade do menor. E institui uma reorganização administrativa que comporta as Delegacias de Menores (SILVA, 2011). Chama a atenção que o tema da periculosidade é amplamente discutido na obra de Foucault $(2008,2010)$ a partir dos discursos das "classes perigosas" às quais se organizam sistemas para seu controle, entre estes, a prisão como instrumento de administração dos corpos.

Ao final dos anos 1940, uma nova discussão desponta no cenário internacional, são as teorias da chamada Proteção Integral, defendida pela Declaração Universal dos Diretos do Homem de 1948 e a Declaração dos Direitos da Criança de 1959. No Brasil, entretanto, essa discussão será descontinuada pela imposição do regime ditatorial militar. 
A Ditadura Militar brasileira leva a discussão acerca do Código de Menores para as pautas de segurança pública. O Serviço Nacional de Assistência a Menores (SAM) é substituído pela Fundação Nacional do Bem Estar do Menor (FUNABEM), criada em 1964. Tal órgão centralizava especialmente as infracionalidades e, subscritos a este foram implementadas nos estados as FEBEM, Fundações Estaduais do Bem Estar do Menor.

Em 1979, é promulgado um novo Código de Menores, que, segundo Sousa (2015), consagra a Doutrina da Irregularidade, apontando às crianças e aos adolescentes um estado de "patologia jurídico-social" e a "criminalização da pobreza" reificada (p. 27). Este Código legitima a internação do menor, ainda que não praticasse ato contrário à lei (p. 28).

Pela legislação que vigorou no Brasil de 1927 a 1990 - o Código de Menores, particularmente em sua segunda versão -, todas as crianças e jovens tidos como em perigo ou perigosos (por exemplo: abandonado, carente, infrator, apresentando conduta dita anti-social, deficiente ou doente, ocioso, perambulante) eram passíveis, em um momento ou outro, de serem enviados às instituições de recolhimento. $\mathrm{Na}$ prática isto significava que o Estado podia, através do Juiz de Menor, destituir determinados pais do pátrio poder através da decretação da sentença de "situação irregular do menor" (ARANTES, 2008: 152).

De acordo com Sousa (2015), em apuração, 80\% dos jovens institucionalizados no sistema FEBEM não eram autores de atos conflitantes com a lei.

A trajetória do sistema FEBEM-FUNABEM é marcada por um histórico de conflitos e denúncias de maus-tratos e rebeliões, em diversos Estados. 


\section{Proteção Integral e o Estatuto da Criança e do Adolescente}

Com a abertura política e a promulgação da Constituição em 1988, oficializavase no Brasil a Doutrina da Proteção Integral. Sendo o Brasil signatário na Convenção das Nações Unidas de Direito da Criança, realizada pela Organização das Nações Unidas (ONU), em 1989. Cabe, porém, destacar a participação de movimentos e organizações da sociedade civil que encaminharam à pauta a proteção integral de crianças e adolescentes, e desde o início dos anos 1980 se articulavam em encontros e fóruns, tendo papel decisivo sobre os dispositivos legais após a abertura democrática do Estado.

Em 1990, com a promulgação da Lei Federal 8.069, fica instituído o Estatuto da Criança e do Adolescente (ECA). O ECA consolida a prerrogativa da proteção integral e institui um sistema de garantia de direitos de crianças e adolescentes, compartilhando responsabilidades entre as famílias, órgãos da sociedade como um todo e o Estado.

Essa descentralização de responsabilidades é uma oposição direta ao modelo tutelar, predominante pelos órgãos do Estado até então. A Constituição de 1988 apresenta, por meio de seu artigo 227, o dever da família, da sociedade e do Estado assegurar à criança e ao adolescente, "com absoluta prioridade”, seus direitos: "o direito à vida, à saúde, à alimentação, à educação, ao lazer, à profissionalização, à cultura, à dignidade, ao respeito, à liberdade e à convivência familiar e comunitária”. Outro ponto de destaque é a compreensão da criança e do adolescente como humano em desenvolvimento, cuja imputabilidade inicia a partir dos 18 anos. Deste modo, preservase o desenvolvimento dos sujeitos e sua garantia de direitos humanos fundamentais, por meio das instituições do Estado e da sociedade, em detrimento de práticas de encarceramento e institucionalização. 
Os marcos da infância, adolescência e juventude no Brasil são representados por sua história institucional, ligada a campos jurídicos-discursivos, que refazem um percurso entre a caridade e o direito. Particularmente, a história dos jovens pobres representa uma preocupação que acompanha o desenvolvimento dos setores da assistência social, da saúde pública, e parte do sistema jurídico do país.

A princípio, instituições dedicadas aos cuidados de crianças e jovens abandonados. Posteriormente, instituições asilares de orientação ao mundo produtivoocupacional, com base num princípio de proteção que supostamente evitasse a vadiagem, e num saber popular que preconiza a institucionalização (reclusão) como recurso protetivo. Observemos como estes saberes se desenrolam, desenvolvendo uma racionalização da saúde e da assistência, na qual as instituições totais, as fechadas, em estilo prisional, têm grande importância (Foucault, 2008).

À pobreza administra-se, desde sua tenra idade, um sistema organizado de prevenção de riscos, "prevenção, educação, recuperação e repressão" deslocam os dispositivos do Poder Público num Brasil que passa por contextos de urbanização rápida e desigual. Objeto de tutela, a infância e juventude representavam risco iminente de "abandonos" material ou moralmente, requerendo do Estado uma intervenção institucionalizante (ARANTES, 2015). Autoridade policial e a letra jurídica aprisionavam os chamados "menores", como meio de tirar da vista as desigualdades, incorporadas por estas chamadas "situações irregulares".

Os sistemas FUNABEM-FEBEM não modificaram essas prerrogativas, detendo, até a proclamação do ECA, legitimidade de internar os "menores", mesmo que não houvesse infração à lei. Tal poder garantido às instituições do Estado produz, ainda nos dias de hoje, reverberações práticas e moralmente. 
A instituição do ECA objetiva não somente a reorganização dos dispositivos legislativos, como uma mudança na compreensão do entendimento sobre a infância e adolescência, aplicável, em teoria, a todas as classes sociais e etnias. Tratam-se de etapas de desenvolvimento humano, que requerem atenção e compreensão específicas. A noção de pessoa em desenvolvimento deve assegurar a proteção dos entes da sociedade e do Poder Público mediante esta peculiaridade.

A descentralização das responsabilidades implica que família, Estado e sociedade compartilhem na constituição e formação subjetiva e afetiva, biológica e social de crianças e adolescentes, através de proteção e garantia de seus direitos. Defende-se, portanto, que as vidas de crianças e adolescentes requerem uma integridade física, psicológica e social, cuja preservação constitui sua subjetividade até seu ingresso na vida adulta, reconhecendo-se desta maneira sua cidadania.

Finalmente, nesta concepção, o ato em conflito com a lei, praticado por adolescente, denota um desencontro num contrato coletivo, cuja resposta pelos mecanismos legais acionará os envolvidos (o jovem, a família, o Estado, a comunidade) tendo em vista a (res)socialização destes sujeitos-cidadãos.

\section{O fim do Sistema FEBEM-FUNABEM}

Tendo a premissa da proteção integral, impõe-se a revisão do sistema FEBEMFUNABEM, que então vinha sendo denunciado por diversos órgãos de defesa de direitos humanos por maus-tratos, violências e violações de direitos. Em 2006, é implementado o Sistema Nacional de Atendimento Socioeducativo - SINASE, regulamentado, posteriormente, em 2012. Entre suas principais medidas, descentraliza a 
gestão das medidas socioeducativas nos entes da federação, cabendo aos Municípios um papel de destaque na gestão das medidas socioeducativas em meio aberto. Já as unidades de medida socioeducativa em meio fechado, cuja gestão predominantemente cabe aos Estados, passam pela reformulação de seus protocolos para o modelo administrativo denominado de Gestão Compartilhada (LIMA, 2010:102), no qual deve haver participação conjunta entre o Poder Judiciário e órgãos do Poder Executivo municipais e estaduais, especialmente, ligados à Educação, Saúde e Assistência Social, além da participação de organizações da sociedade civil e dos Conselhos de Direitos da Criança e do Adolescente. O SINASE é resultado de discussões entre o poder público e organismos de participação social, especialmente o CONANDA, Conselho Nacional dos Direitos da Criança e do Adolescente. O objetivo primordial do SINASE é o “desenvolvimento de uma ação socioeducativa sustentada nos princípios dos direitos humanos", (BRASIL, 2006). A instituição do SINASE se dá por meio da Resolução no 119/2006, do CONANDA, e posterior promulgação da Lei Federal 12.594/2012.

\section{O Sistema Nacional de Atendimento Socioeducativo (SINASE) e as Medidas}

\section{Socioeducativas}

Neste sistema de proteção integral, quando criança e adolescente apresentam-se em conflito com a lei, em situação análoga a crime (conforme Código Penal), entendese que esta contravenção será tratada em juízo específico / especial (Vara Especial). Cabendo a crianças (até 12 anos de idade) receber Medida Protetiva (Artigo 101 do ECA), e aos adolescentes (entre 12 a 18 anos, podendo cumprir medida até os 21 anos de idade) receber Medida Socioeducativa (Artigo 112 do ECA). 
Constitui-se, a partir do ECA, uma perspectiva de atendimento que priorize socialização e educação. Portanto, a descrição das Medidas Socioeducativas já consta no ECA (1990), tendo sua execução regulamentada pela Lei do SINASE (2012).

Deste modo, conforme Artigo 112 da Lei 8.069/1990 são medidas socioeducativas:

I - advertência;

II - obrigação de reparar o dano;

III - prestação de serviços à comunidade;

IV - liberdade assistida;

V - inserção em regime de semiliberdade;

VI - internação em estabelecimento educacional;

VII - qualquer uma das medidas protetivas previstas no art. 101, do ECA.

A Lei do SINASE regulamenta que os programas de atendimento socioeducativo serão mantidos sob responsabilidade do Poder Executivo, nos diferentes níveis federativos, não podendo ser pelo Poder Judiciário.

As medidas socioeducativas restritivas de liberdade ou em meio aberto são de responsabilidade dos Municípios. As principais medidas socioeducativas em meio aberto são: Prestação de serviços à comunidade e Liberdade assistida.

- Prestação de serviços comunitários (Art. 117 do ECA) consiste na realização de tarefas gratuitas de interesse geral, por período não excedente a seis meses, junto a entidades assistenciais, hospitais, escolas e outros estabelecimentos congêneres, bem como em programas comunitários ou governamentais. O cumprimento deve obedecer uma jornada máxima de oito horas semanais, e em dias e horários de modo a não prejudicar a frequência escolar e de trabalho. 
- Liberdade assistida (art. 118 e 119 do ECA) consiste em ações sistematizadas de acompanhamento, auxílio e orientação do adolescente em conflito com a lei. O Poder Judiciário designará os técnicos para assistência ao jovem, sendo recomendados pelos programas de atendimento dos Municípios. Nesta medida, cumpre acompanhar e proporcionar a promoção social do jovem infrator, sua frequência escolar e seu sentido de profissionalização, e aos técnicos a apresentação de relatórios sobre o caso. O prazo mínimo de cumprimento desta medida é seis meses, podendo ser prorrogada, revogada ou substituída por outra medida, após audiência dos técnicos, do Ministério Público e do defensor.

As medidas socioeducativas que implicam privação de liberdade ou em meio fechado são de responsabilidade dos Estados. As principais medidas socioeducativas de privação de liberdade são: Semiliberdade e Internação.

- Semiliberdade (Artigo 120 do ECA) consiste na transição da medida para o meio aberto, possibilitando a utilização de recursos da comunidade e mantendo a obrigatoriedade da escolarização e profissionalização do jovem em conflito com a lei.

- A Internação (Art 121 do ECA) está sujeita a caráter de brevidade e excepcionalidade, conforme doutrina do ECA. Esta medida possui o prazo máximo de três anos de execução, e a liberação compulsória após completos 21 anos de idade pelos sujeitos. Também cabe à medida de internação reavaliação periódica, possibilitando sua substituição por semiliberdade ou liberdade assistida. Conforme Art. 122, a internação não deve em nenhuma hipótese ser recomendada, havendo outra medida mais adequada.

Sua aplicação se dá em casos de: 
I - Tratar-se de ato infracional cometido mediante grave ameaça ou violência a pessoa;

II - por reiteração no cometimento de outras infrações graves;

III - por descumprimento reiterado e injustificável da medida anteriormente imposta.

- A internação também poderá ocorrer de maneira provisória. Internação provisória, conforme Art. 108 do ECA, a internação pode ser determinada antes da sentença. Para que isto ocorra a decisão judicial deverá ser fundamentada e baseada em indícios suficientes de autoria. Demonstrando-se a necessidade desta medida, não poderá durar mais de 45 dias.

Schuch (2014) define que a reconstrução democrática brasileira ao situar jovens enquanto sujeitos de direitos enseja "novas formas de governo da infância e juventude", “a atual matriz dos direitos [...] investe na participação da comunidade nas políticas de atendimento e reconfigura crianças e adolescentes como "sujeitos de direitos" e de proteção integral do estado, família e comunidade". Estes últimos passam a ser o "meio" de aplicação das ações e das técnicas de governo, assim como se configuram "sujeitos políticos”, mobilizadores de práticas de governo, lutas e posições sociais.

\section{Cidadania e juventude}

Tomando como definição de cidadania o conceito de Fleury e Ouverney (2008), o da cidadania a partir da inclusão numa "comunidade política nacional", o pertencimento a essa comunidade política pressupõe também "um vínculo jurídico e político, o que requer a participação ativa dos indivíduos na coisa pública”. Nesta noção, deve estar disposta na configuração da "cidadania" a existência de um 
reconhecimento na esfera coletiva de sua necessidade, e sua pactuação por um conjunto que assegure a legitimidade desse reconhecimento, vinculando sujeitos, Estado e sociedade ao campo jurídico e político, e por fim, a garantia de participação política dos membros da comunidade e a possibilidade de repactuação dos acordos reclamando seu reconhecimento. Tentando adaptar o raciocínio, podemos pensar na Constituição Federal como o vínculo que ampara jurídica e politicamente a cidadania, o reconhecimento por meio de instrumentos, como o Estatuto da Criança e do Adolescente, por exemplo, enquanto instrumentos legitimadores e garantidores desse sistema. Numa instância posterior, essa noção tem a ver com "ter direitos" ou "o direito a ter direitos", direitos políticos, civis e sociais, num reconhecimento de um acordo coletivo entre Estado, sociedade e seus sujeitos, agora chamados "cidadãos".

De acordo com Monteiro e Castro (2008), essa noção "clássica" de cidadania, "baseada em direitos e no pertencimento a um Estado-nação tem enfrentado inúmeros questionamentos e passa por reconfigurações em função de mudanças no contemporâneo" (p. 271). E é nesse cenário que emerge a noção de crianças, adolescentes e jovens na posição de "sujeitos de direitos", no Brasil (fortemente em articulação ao movimento internacional), ao final dos anos 1980 e início dos 1990, é instituído o Estatuto da Criança e do Adolescente (ECA), afirmando uma posição de cidadania para crianças, adolescentes e jovens, especialmente, aqueles das camadas pobres da população, para quem era premente afirmar "terem direitos", já que nas classes média-alta e alta estes são tomados por óbvios.

A proteção integral é um conceito importante, que orienta nossas discussões e embasa muitos dos relatos na presente pesquisa. Trazido pelo ECA, propondo reordenamento do aparato institucional no amparo às crianças e adolescentes a partir de 
um compromisso entre famílias, sociedade e Estado. A proteção integral implica na oferta de direitos e proteção de garantias, como segurança, saúde, inclusão social, convívio familiar, nessa concepção da cidadania infanto-juvenil. Monteiro e Castro (2008) afirmam que as práticas de assistencialismo e institucionalização "deram lugar a discursos e práticas de afirmação de defesa, reconhecimento e respeito destes sujeitos" (p. 279). As autoras, porém, ressaltam que a noção de cidadania que se configura para adolescentes e jovens, após o ECA, reafirma direitos sociais, por outro lado, pouco trata da participação social e dos direitos políticos.

O ECA presume a cidadania como uma etapa "em desenvolvimento" durante a infância adolescência e juventude. "Cidadania plena" seria, para José Murilo de Carvalho (2005), um ideal de difícil alcance que envolveria o acesso e exercício da "liberdade, participação e igualdade para todos". Este autor faz uma definição pelos tipos de direitos pelos quais passa a noção de cidadania, sendo costume desdobrar essa noção a partir do uso desses direitos: civis, políticos e sociais.

Direitos civis são os direitos fundamentais à vida, à liberdade, à propriedade, à igualdade perante a lei. Eles se desdobram na garantia de ir e vir, de escolher o trabalho, de manifestar o pensamento, de organizar-se, de ter respeitada a inviolabilidade do lar e da correspondência, de não ser preso a não ser pela autoridade competente e de acordo com as leis, de não ser condenado sem processo legal regular. São direitos cuja garantia se baseia na existência de uma justiça independente, eficiente, barata e acessível a todos. São eles que garantem as relações civilizadas entre as pessoas e a própria existência da sociedade civil surgida com o desenvolvimento do capitalismo. Sua pedra de toque é a liberdade individual. [...] Direitos políticos [...] se referem à participação do cidadão no governo da sociedade. Seu exercício é limitado a parcela da população e consiste na capacidade de fazer demonstrações políticas, de organizar partidos, de votar, de ser votado. Em geral, quando se fala de direitos políticos, é do direito do voto que se está falando. [...] Finalmente, há os direitos sociais, [...] garantem a participação na riqueza coletiva. Eles incluem o direito à educação, ao trabalho, ao salário justo, à saúde, à aposentadoria. A garantia de sua vigência depende da existência de uma eficiente máquina administrativa do Poder Executivo (CARVALHO, 2005: 9-10). 
O acesso e exercício de um, mas não de todos os direitos define os "cidadãos incompletos", conforme o autor, enquanto aqueles que não têm acesso a nenhum desses conjuntos de direitos será definido como "não-cidadão".

As reivindicações acerca da participação social e exercício de direitos políticos pelos jovens se organizam em movimentos como as Conferências da Juventude, a primeira tendo ocorrido em 2008 (CRIVELARO, 2016). E em 2012, há a promulgação do Estatuto da Juventude, visando reafirmar uma série de direitos para jovens, além de estender a idade de definição de juventude, entre 14 a 29 anos de idade, havendo uma coincidência em determinada faixa etária com o ECA (que considera adolescentes sujeitos entre 12 a 18 anos de idade).

A noção de cidadania implica que na esfera social, em contínuas transformações, novas propostas constantemente se organizem, reivindicando legitimação de suas identidades e inserção no pacto coletivo, na "cultura política". Assim, a cidadania juvenil emerge no campo de interfaces (e às vezes, disputas) junto a outras pautas, como a racial, indígena, LGBT, de mulheres, os movimentos de moradia.

A cidadania acontece, em alguma medida, no reconhecimento ou em suas possibilidades de reinvindicação de condições e contextos específicos para a participação na esfera cidadã.

Considerando os sujeitos que interessam no presente estudo, entendemos algumas dessas especificidades, jovens, negros, pobres, moradores de periferias, como condições que os tornam inscritos nos discursos enquanto vulneráveis, no cenário das políticas sociais de cidadania. Este conceito é relevante à medida que surge nos relatos e nas discussões. O conceito de vulnerabilidade se relaciona com a noção apresentada por Ayres et.al. (2009), que o utiliza no contexto das políticas de prevenção à Aids, como 
estratégia de avaliação dos recursos e medida de planejamento interventivo dentro das políticas de saúde, sociais e econômicas.

O conceito de vulnerabilidade é, simultaneamente, construto e construtor dessa percepção ampliada e reflexiva, que identifica as razões últimas [...] e seus impactos em totalidades dinâmicas formadas por aspectos que vão de suscetibilidades orgânicas à forma de estruturação de programas de saúde, passando por aspectos comportamentais, culturais, econômicos e políticos (Ayres et. al., 2009: 121-122).

Além deste conceito, a noção de "violação de direitos" emerge nos discursos, relacionadas a condicionantes, como a pobreza, e os contextos da infracionalidade.

No tópico a seguir, tratamos da produção discursiva da temática da infância, adolescência e juventude, buscando sua origem a partir dos campos de produção de conhecimento históricos e das ciências sociais.

\section{Estado, Estados, agentes do Estado, Poder, poderes}

Retomando Foucault, este autor nos apresenta uma noção de Estado / poder que não passa por um corpo integralmente consolidado, coeso, homogêneo, o autor nos apresenta o conceito de "capilaridade", a partir do qual Estado / poder nem sempre será exercido irradiado de cima pra baixo, ou seja, imposto numa direção vertical, e confronta resistências e conformidades nesse percurso. "Para que haja um movimento de cima para baixo, é preciso que haja ao mesmo tempo uma capilaridade de baixo para cima" (FOUCAULT, 2010: 250).

O poder não existe. Quero dizer o seguinte: a ideia de que existe, em um determinado lugar, ou emanando de um determinado ponto, algo que é um poder, me parece baseada em uma análise enganosa e que, em todo caso, não dá conta de um número considerável de fenômenos. Na realidade, o poder é um feixe de relações mais ou menos organizado, mais ou menos piramidalizado, mais ou menos coordenado (FOUCAULT, 2010: 248). 
Ao tratar do poder, suas conformidades, irradiações e resistências, Foucault argumenta por uma capilaridade de poder(es), pela qual, para além do Estado, existem agentes e agências que exercem, disputam, ocupam, disputam, deslocam os usos do poder - jogos de poder. Assumindo essa premissa no contexto da pesquisa, encontramos ao longo do trabalho representações das relações de poder, - os relatos utilizam principalmente o termo "o Estado", que organizam sentidos muitas vezes divergentes sobre "o Estado" e o exercício de poder.

O poder aparece nos discursos da pesquisa denominado como Estado, e fala de seus possíveis agentes e agências que em alguma medida utilizam de possibilidades de poder. Nossos interlocutores, eles mesmos, são também trabalhadores que representam de alguma maneira essa ação do Estado - a que desenvolve o trabalho socioeducativo junto a jovens implicados em contextos de conflito com a lei. Os mesmos relatam outros agentes que circulam a representatividade do Estado (o poder policial ou o Poder Judiciário, por exemplo), além de outros discursos que concorrem com seu entendimento sobre condutas junto aos jovens, com os quais precisam tratar. Ainda, outras expressões do Estado se revelam pelo trabalho desenvolvido junto a outros serviços - também representativos do Estado, como a saúde, a educação, etc. Seja na expressão pela via da exclusão, é comum nos relatos a frase "a falta do Estado", para tratar de uma proposição do Estado que não se dá pela via da inclusão dos sujeitos e seu reconhecimento cidadão, mas em omissões e negligências, identificadas pelos nossos interlocutores como sistemáticas. São diversas, portanto, as faces de Estado que se apresentam aos jovens de que falam nossos interlocutores. 


\section{Estado e desdobramentos do poder, biopolítica e questão racial}

A noção de biopolítica advém da obra foucaultiana, Foucault (2005, 2008 e 2010) e trata do desenvolvimento de métodos de gestão, próprios à Modernidade, que remetem aos primórdios do pensamento liberal. Localiza-se historicamente a existência de um raciocínio próprio ao governar - a governamentalidade, que implica a soberania do Estado, e incorpora os conceitos biológicos enquanto processos políticos. Foucault trata da emergência de campos de produção de saberes-poderes nas tecnologias de gestão que darão origem à Medicina Preventiva, à Estatística, à Administração, entre outras conjuntos teóricos-científicos, que então operavam em favor da regulamentação dos corpos na sociedade capitalista.

O controle da sociedade sobre os indivíduos não se opera simplesmente pela consciência ou pela ideologia, mas começa no corpo, com o corpo. Foi no biológico, no somático, no corporal que, antes de tudo, investiu a sociedade capitalista. O corpo é uma realidade biopolítica. A medicina é uma estratégia biopolitica (FOUCAULT, 2010).

Posteriormente, o autor retoma o conceito de biopolítica para tratar de uma teoria da soberania, que se desenvolve na modernidade e cujas concepções serviram sobre as guerras e sobre a questão racial. Nesta teoria, destaca-se, "a vida e a morte não são desses fenômenos naturais, imediatos, de certo modo originais ou radicais, que se localizariam fora do campo do poder politico". Segundo essa perspectiva, na organização jurídica e teórica de uma soberania, "em relação ao poder", aqueles estabelecidos enquanto "súditos" não são "em pleno direito", "nem vivo(s) nem morto(s)". No controle biopolítico, "é simplesmente por causa do soberano que o súdito tem direito de estar vivo ou [...] de estar morto". "Em todo caso, a vida e a morte dos súditos só se tornam direitos pelo efeito da vontade soberana”. Foucault denomina uma dissimetria de direitos, uma vez que o poder soberano se exerce a partir "do direito de 
matar”. A relação de soberania estudada por Foucault verifica a emergência, entre os séculos XVIII e XIX, de tecnologias, disciplinas (os campos de saber) e instituições de controle direcionadas, tanto aos corpos dos indivíduos, como voltadas ao todo populacional, "a segurança do conjunto em relação aos seus perigos internos".

É importante destacar que Foucault insere o conceito de biopolítica no contexto do estudo da modernidade, pensando nas possibilidades de leituras sobre a sociedade contemporânea, sob a égide do capitalismo liberal. Entende que as tecnologias e técnicas de gestão de corpos também se aplicarão à gestão de populações. "Agora que o poder é cada vez menos o direito de fazer morrer e cada vez mais o direito de intervir para fazer viver" (FOUCAULT, 2005: 225). Esse movimento tende a gradualmente se converter numa relação soberana que aos poucos de desvencilha, embora não completamente, de sua função de "fazer morrer", e assume o "fazer viver" e o "deixar morrer" como estratégias.

No entanto, a soberania biopolítica não se desfaz completamente de seu potencial em "fazer morrer", assumindo para si propostas de suposto embasamento biológico como teorias de higienismo e racismo. "Em linhas gerais, o racismo, acho eu, assegura a função de morte na economia do biopoder" (FOUCAULT, 2005: 308).

Agamben (2007) retoma os conceitos de biopolítica a partir da leitura de Foucault, compreendendo os cenários da "morte" e da "vida" em disposição ao campo jurídico e à política. Percebe que essa noção produz vidas que somente se constituem “em exclusão" ou "em oposição", externas à legitimidade estabelecida juridicamente e pelo Estado, definidas pelo conceito extraído do direito romano de "homo sacer". A partir deste, o autor apresenta-nos o conceito de "vidas nuas", estas emergem do lado oposto às proteções políticas, facilmente configurando-se "vidas matáveis" pelo Estado. 
Conforme Ribeiro e Benelli (2017) o racismo surge, nesse contexto da modernidade, a partir de construções discursivas de povos "perigosos" ou "infiltrados" nas dinâmicas populacionais.

Surge, portanto, o racismo moderno ou, tal como compreendido por Foucault, o racismo biológico. O discurso da raça no singular, no qual se ancora o racismo, passa a ser assegurado por técnicas médico-normalizadoras devido à transferência da lei para a norma e do jurídico para o biológico, da transição da pluralidade de raças para o singular da raça (RIBEIRO e BENELLI, 2017: 248).

Ainda neste sentido, Foucault (2005) dirá:

Está ligado a isto que nos coloca, longe da guerra das raças e dessa inteligibilidade da história, num mecanismo que permite ao biopoder exercer-se. Portanto, o racismo é ligado ao funcionamento de um Estado que é obrigado a utilizar a raça, a eliminação das raças e a purificação das raças para exercer seu poder soberano. A justaposição, ou melhor, o funcionamento, através do biopoder, do velho poder soberano do direito de morte implica o funcionamento, a introdução e a ativação do racismo. E é aí, creio eu, que efetivamente ele se enraíza (FOUCAULT, 2005).

Pensando os contextos locais, nos processos históricos sociais produtivos e discursivos do Brasil, assim como, do Estado e Município de São Paulo, há uma grande literatura que trata de processos históricos de exclusão da população negra. Tomando por base os dados apresentados previamente, no que cabe à juventude negra de São Paulo, pensamos nos mecanismos que a inserem pelas margens na organização urbana, na produção dos "menores infratores" ou "delinquentes", jovens que, conforme esses mesmos dados, apresentam uma faixa etária coincidente, residem nas periferias de uma grande capital como São Paulo, e são também potencialmente controlados e identificados e regulados pela ação do Estado, por meio de seus agentes policiais e instituições, sendo ainda conforme os dados os mais atingidos pelas dimensões de violência e letalidade. 
Ribeiro e Benelli (2017) apontam que a questão racial se insere em articulações biopolíticas, numa relação de "fazer morrer / deixar morrer", que decorre, ora da ação, outrora da omissão do Estado no que tange à juventude negra (p. 249).

Wacquant (2003) é um autor que trata da desmobilização do Estado de bemestar social (welfare). Tendo este processo como referência, podemos pensar no contexto atual de São Paulo e do Brasil, onde, ao mesmo tempo em que há redução dos investimentos em políticas sociais, ocorre um acirramento de discursos e propostas punitivas de todas as ordens, na condução das políticas de inclusão / exclusão, acesso / restrição, o que certamente tem efeitos na geografia das desigualdades sociais de São Paulo e do Brasil. Wacquant (2012) denomina tais propostas enquanto "prisonfare", implicando no investimento em políticas públicas de fundo repressor e punitivo, e, assim como as políticas sociais, seu objetivo é intervir e regular sobre a população e os corpos dos pobres. No entanto, uma transição completa de um modelo de bem-estar social para um modelo penal não ocorre, produzindo as políticas de "dupla disciplina", pela vigência simultânea dessas propostas.

Na busca de uma associação aos contextos periféricos da cidade, as autoras Das e Poole $(2004 ; 2008)$ apontam que "a relação entre a violência e as funções ordenadoras do Estado é a chave para o problema das margens". Ainda que, para essas autoras, a legitimidade do Estado se dá como resultado da demarcação de seus limites em relação às suas margens. As práticas do Estado territorializam e localizam estratégias de controle, em lugares que não são "meramente territoriais", são também "lugares de prática onde a lei e outras práticas estatais são colonizadas mediante outras formas de regulação que emanam das necessidades prementes das populações”. A relação entre soberania e formas disciplinares de poder conformam, de acordo com Das e Poole 
(2008), as concepções acerca das margens do Estado. O conceito de "margens" para essas autoras deve ser compreendido a partir de três entendimentos: "margem como periferia", margem como "legitimidade e ilegitimidade" e, finalmente, a margem como “o espaço entre os corpos, a lei e a disciplina" (DAS e POOLE, 2008).

\section{Juventudes, crime, pobreza e violências: abordagens sociológicas}

Discorremos aqui a partir de autores das ciências sociais possíveis abordagens interpretativas sobre o tema da violência na juventude. Ora como "problema social", com características que remetem ao ethos do sujeito, ou em interpretações que demarcam a relação com o Estado ou as relações de classe como importantes sentidos a serem levados em conta neste entendimento.

Pais (1990) ao dividir as correntes interpretativas da sociologia da juventude, já nos apresenta modelos, oriundos destas correntes, que tratam a "delinquência juvenil". Numa dessas abordagens de interpretação, a "funcionalista", explica-se o comportamento "delinquente" como certa incapacidade de ajuste às normas de comportamento dominantes. Partindo de um raciocínio "geracional", esta incapacidade de adaptar-se é manifestação própria do jovem de modo a deliberadamente inverter "os valores das gerações mais velhas". Explicada a partir de um critério geracional, a "delinquência" relaciona-se a uma série de indeterminações, frustrações e tensões que surgem no seio intergeracional. Já, a partir de uma perspectiva classista, a "delinquência" surge como manifestação dos conflitos das classes sociais inferiores. Enquanto expressão de conflitos de classe, portanto, a delinquência juvenil poderia também surgir em forma de resistência aos valores e às contradições ideológicas do consumo. O controle e a repressão surgem como características da sociedade, nesta 
corrente, pautando que os estratos mais pobres sejam mais reprimidos pelas ações da polícia e pelo sistema de justiça.

Acompanhamos aqui a análise de Lyra (2013), segundo a qual, na sociologia brasileira, o tema da "adesão do jovem ao crime" é objeto percorrido por diferentes parâmetros, entre os quais, o autor destaca as abordagens da "compreensão material" e a "teoria do reconhecimento". A primeira perspectiva parte da precariedade material dos sujeitos, sua implicação ou adesão, nesta abordagem, relaciona-se ao desejo de consumir, tem como referência a autora Alba Zaluar e uma literatura referenciada às pesquisas da mesma. Já, no entendimento das teorias do reconhecimento, minoritária, tem como referência o autor brasileiro Luiz Eduardo Soares, caracteriza-se uma "fome simbólica de existência", pauta-se aqui a "invisibilidade social" e o desejo de existir (p. 72).

Lyra, ele mesmo, desenvolve também sua perspectiva analítica, que se soma às demais, na qual "independência e "realização" tornam-se sentidos que prosperam no desenvolvimento do jovem "do morro", Este transita, segundo o autor, pelas etapas: infância, individuação e autonomia, de modo que sua "adesão" explica-se no intervalo entre as duas últimas com fins de autonomia, mas também com efeitos subjetivos nos sentidos atribuídos às suas "vontades" "interesses", "necessidades" e "farras" (Lyra, 2013).

Em Zaluar, a autora busca articular por meio da literatura das ciências sociais as dimensões "objetivas, macrossociais ou estruturais com as dimensões subjetivas, microssociais ou do agir". Resgatando o "processo civilizador" do sociólogo Norbert Elias, Zaluar traz o conceito de "etos guerreiro", noção importante para seu

\footnotetext{
${ }^{5} \mathrm{O}$ autor trabalhou em sua pesquisa os jovens em conflito com a lei moradores de favelas do Rio de Janeiro.
} 
desenvolvimento teórico. Este etos guerreiro se refere ao modo como as lutas são empreendidas por meio da "violência física e à maneira como os conflitos ou rivalidades são resolvidos pela supressão física de uma das partes". A este "etos" se opõe outro, um "etos civilizatório", relacionado ao empenho sublimador da força do primeiro, sensível ao sofrimento alheio e maior controle emocional. Zaluar recorre ainda a Bourdieu, e encontra fundamento na teoria da dominação masculina, também chamada "etos da masculinidade". Para este autor, "toda forma de poder é simbolicamente violenta". A dominação se estabelece na assimetria de poder entre dominantes e dominados.

A autora aponta que as relações violentas têm constituição histórica no Brasil, entre os sentidos, a desigualdade da distribuição do uso da violência, sua legitimação e responsabilização perversa produzem efeitos como o surgimento "de grupos de extermínio e de justiceiros, de empresas de segurança privada”, entre outras associações que indicam a ineficácia da ação estatal sobre a violência. "Na verdade, o Estado brasileiro ainda não cumpriu satisfatoriamente a principal função de todo o estado: dar segurança a seus cidadãos” (ZALUAR, 2014: 37).

Em suas pesquisas, Zaluar (2014) aponta a disponibilidade de armas e seu fácil acesso aos jovens moradores das periferias, segundo a autora. "Jovens passaram a andar armados para se proteger de outros jovens armados” (p. 37). A resolução dos conflitos por meio das armas desponta como corriqueira no cotidiano dos sujeitos entrevistados pela autora. "Crianças e adolescentes cresciam vendo a exibição ostensiva das armas como símbolos de poder e o seu uso cruel para punir ou vingar quem atravessava o caminho dos traficantes armados e dos policiais corruptos" (p. 38). A autora aponta que a violência acontece na adoção de "códigos e práticas sociais não conscientes" 
pertencentes ao dia-a-dia de jovens envolvidos com o tráfico, desenvolvendo uma tendência à insensibilidade, ao sofrimento e a práticas brutais. O "etos guerreiro" do tráfico.

Agrava-se a este cenário a relação das práticas policiais com os territórios periféricos. Produzindo-se uma guerra entre grupos armados, "poderes paralelos".

O etos guerreiro, incorporado por homens jovens, se manifesta na utilização da violência tanto como recurso para obter ganhos comerciais no tráfico de drogas, no contrabando de armas e outras atividades ilegais, como também uma forma de expressão nas relações entre homens que se desafiam mutuamente "na defesa até a morte de um orgulho masculino construído sobre o controle do território assim obtido" (PIMENTA, 2014: 226).

Finalmente, Zaluar apresenta uma pista para abordar estes fenômenos: a necessidade de levar-se em conta “a dimensão da sociabilidade já construída”. A desigualdade social reflete nos modos de inclusão / participação na sociedade, e, portanto, produz respostas na aquisição dos sujeitos e disposição direcionada ao confronto ou à mediação. Somados a isto, existe um trabalho da indústria cultural, e a produção de desejos de consumo. O consumo se associa às desigualdades de participação, e está presente, portanto, nas dinâmicas da violência.

(Por meio da) rápida difusão na indústria cultural dos novos estilos de cultura jovem, transformou parcialmente os jovens em consumidores de produtos especialmente fabricados para eles, sejam vestimentas, sejam estilos musicais, sejam drogas ilegais (ZALUAR, 2004).

Uma das críticas a este modelo interpretativo se dá em resumir nas capacidades individuais (emocionais, impulsivas, autocontrole), enquanto medida social para o comportamento violento ou criminal, a "sociabilidade" violenta e perversa. "O fio condutor entre a desagregação familiar e a adesão ao tráfico de drogas seria explicado pela irrupção de uma nova identidade masculina, centrada na virilidade guerreira" (LYRA, 2013: 27). 
Na perspectiva de Soares (2004), a invisibilidade se destaca e atravessa os marcadores do tema. "Uma das formas mais eficientes de tornar alguém invisível é projetar sobre ele ou ela um estigma, um preconceito". Segundo o autor, é premente empreender um esforço para compreender o "drama da juventude brasileira", num cenário de desigualdades e dados alarmantes. Um cenário social que produz estereótipos e preconceitos - "estigmas", como denomina o autor, - produz ao mesmo tempo meios de "prevenção" que justificam o uso de violência contra os diferentes. O autor aponta ainda a indiferença e negligência perante os mais pobres como produtora de invisibilidade. "Também por conta de nossa negligência, muitos jovens pobres, especialmente os negros, transitam invisíveis pelas grandes cidades brasileiras" (SOARES, 2004).

Existe, conforme Soares, um mecanismo adaptativo, que muitas vezes opera inconscientemente na sociedade em geral, de modo a retirar sua sensibilidade frente a importantes questões da sociedade. Deste modo, a negligência e invisibilidade se produzem. O autor compreende que para um adolescente e jovem, em sua constituição identitária, "ser visto" é um processo importante em seu desenvolvimento. Soares sustenta seu argumento desenvolvendo uma teoria que passa quase da constituição subjetiva-identitária do adolescente vulnerável. Este adolescente, projetado por preconceitos ou pela indiferença da sociedade, tende à adesão à violência, de modo a provocar um sentimento negativo que lhe garantirá visibilidade. "Ao fazê-lo, saltará da sombra em que desaparecera e se tornará visível. A arma será o passaporte para a visibilidade" (Soares, 2004).

Para as vulnerabilidades da adolescência e juventude, Soares fala de uma fome "mais exigente e voraz que a física", "a fome de sentido e de valor; de reconhecimento e 
acolhimento; fome de ser - sabendo-se que só se alcança ser alguém pela mediação do olhar alheio que nos reconhece e valoriza". Sem excluir o entendimento explicativo materialista, pautado nas necessidades de consumo; porém, chamando atenção ao reconhecimento social, por meio da oferta de perspectivas, num sentido literal, e da participação em grupos, como estratégia identitária ("simbólica"), que o autor nos encaminha a desenvolver propostas de "recuperação" da violência.

Apresenta-se, a partir da cientista social Melissa Pimenta, a perspectiva explicativa que denominamos "transicional", que dialoga com as correntes explicativas funcionalistas e geracionais. Para Pimenta (2014), a juventude, enquanto fenômeno e construção social e cultural, tende a apresentar diferentes modelos de acordo com o contexto histórico e social que a define. Na contemporaneidade, a autora fala de uma grande expectativa para inserção no mercado de trabalho, que pode ser explicada nas perspectivas de transição "intergeracional"'. Ora, se a juventude carrega a expectativa de "geração" posterior, a autonomia, garantida por meio do trabalho e da renda, é um dos condicionantes da "transição" da juventude para a vida adulta, (e, posterior reprodução intergeracional).

Pimenta (2014) aponta a relevância de se compreender esta prospecção para o futuro relacionada à juventude, bem como seus efeitos. "Em um contexto social e econômico que comporta profundas mudanças, os jovens têm se defrontado com dificuldades crescentes tanto de projetar como de vivenciar suas perspectivas futuras" (p. 227). A possibilidade de "projetar o futuro", no entanto, pode ser intervista mediante circunstâncias da vida dos jovens. De modo que os sujeitos, nem sempre poderão ou

\footnotetext{
${ }^{6} \mathrm{O}$ debate sobre as gerações é bastante estabelecido no campo das ciências sociais, tendo grandes referências teóricas se dedicado ao tema (Mannheim (1982), Forachi (1972), Pais (1990), Weisheimer (2014)).
} 
sentirão capacidade de dispor de longitudinalidade de seus projetos, em função das desigualdades de oportunidades do cotidiano em que estão inseridos.

"Uma importante dimensão a ser considerada talvez seja o prolongamento do presente, vivenciado na sua dimensão de satisfação imediata dos desejos" (p. 228). Deste modo a violência e as práticas ilícitas, como o envolvimento criminal ou uso de substâncias, oferta rapidez e oportunidades de ganhos e conquistas.

Feltran (2008a e 2008b), a partir de suas pesquisas realizadas em bairros de periferia da Zona Leste de São Paulo, identifica nestas regiões a convivência entre duas categorias de sentidos que se opõem entre si, os "trabalhadores" e "bandidos". Estas noções tendem a perder o conteúdo semântico a que estão originalmente atreladas, um histórico desenvolvimentista urbano, portando promessas de integração social e acesso aos bens e direitos por meio do trabalho, o que não se cumpriu.

Estas categorias tendem a ser desatreladas de sua carga moral e potencial de coesão social iniciais. Os sentidos originais tendem a se desfazer com o passar dos anos. Esse descompasso, afirma o autor, conduz à uma "pressão por repartição da legitimidade".

Em meio aos conflitos pela legitimidade se organizam movimentos repressivos, como as ações policiais e os "ataques" comandados por grupos de crime organizado, disputando espaços nos territórios de direitos e de legitimidade.

Já para Adalton Marques (2017), a partir de uma racionalidade denominada pelo autor "tríptico segurança pública-democracia-direitos humanos", pela qual se desenvolvem formações discursivas que entendem o enfrentamento da criminalidade pela enunciação da marginalidade, questões como a pobreza, desemprego, desigualdade social permeiam esses discursos, que, por sua vez, têm repercutido em estratégias de 
gestão pública, na esfera federal e no Estado de São Paulo, em estratégias de policiamento e repressão. O autor retoma um debate iniciado entre os anos 1970 e 1980 , tratando da associação feita pela produção acadêmica entre "criminalidade" e "marginalidade", pelo campo da Sociologia da Violência no Brasil, e da "tese da associação entre crime e pobreza", que perpassa parte dessas produções, de modo que a noção de "crime" se associa à violência, embora a princípio não contenham uma relação de necessidade e associação. Para o autor, são essas narrativas de violência-crime que produzem os discursos que apontam à criminalização da pobreza.

Percebe-se a complexidade do tema, de modo que os modelos de leitura da juventude e suas muitas possíveis abordagens nem sempre se encontram e não dão conta de todas as dimensões necessárias ao tema:

Assistimos no Brasil à convivência entre representações dos "jovens como problema", "jovens como sujeitos de direitos", "jovens como sujeitos em transição para a vida adulta" ou ainda da ideia do jovem como sujeito da transformação, jovem como portador das novas tecnologias ou como portador da representação de força e vitalidade. Às vezes dentro de um mesmo governo ou ainda dentro de um mesmo grupo é possível identificar visões díspares sobre qual seria a referência que caracteriza e identifique o sujeito "jovem" (FREITAS, 2012).

Freitas (2012) aponta a importância de levar-se em conta tal diversidade explicativa acerca da juventude, de modo que é a partir das mesmas que se produzem uma multiplicidade de respostas do Estado, e de ações da sociedade civil, em diferentes e, muitas vezes, divergentes compreensões. As modalidades de compreensão podem inspirar o agravamento de produção de associação entre juventude e a violência.

Desta maneira, tal como Freitas (2012) propõe, entende-se a premência do estabelecimento de análises mais largas, multidimensionais, que contribuam à produção de justiça e acesso às políticas públicas nas narrativas e compreensões acerca da juventude. 


\section{Capítulo 3. CUIDADOS E ETAPAS DA CONSTRUÇÃO DA PESQUISA: DOS}

\section{SUJEITOS E DO PESQUISADOR}

Neste item, tratamos de descrever o trabalho realizado em campo frente aos objetivos inicialmente pensados, e como foram encaminhados.

É importante ainda destacar que a pesquisa, inicialmente, fora planejada para realizar-se no formato conhecido como "pesquisa-intervenção" ou "pesquisa-ação", estava prevista uma interação junto ao grupo que é destacadamente tema das discussões neste trabalho: os jovens implicados em atos infracionais, inscritos no sistema de medidas socioeducativas de São Paulo. Ainda que não tenha ocorrido a pesquisaintervenção, em contato com o campo tivemos os cuidados orientados e mais bem definidos por esta modalidade de pesquisa. Ou seja, ainda que não tenha sido possível o desenvolvimento da pesquisa enquanto pesquisa-intervenção, deve-se destacar que o ethos $^{7}$ em campo do pesquisador em sua interação com os colaboradores - os profissionais do sistema de medidas socioeducativas - foi motivado pelas leituras desta modalidade de fazer científico ${ }^{8}$. Mais do que isso, descrevemos neste item os cuidados que tivemos em nossa aproximação do campo e na relação com os interlocutores.

A saber, esses cuidados dizem que o pesquisador não vai a campo investido de seus saberes, e é quando se desveste deste papel de detentor dos arcanos de

\footnotetext{
7 Passos e Benevides (2009) falam a respeito de um ethos que precede à escolha metodológica nas intervenções em pesquisa ou na clínica, de modo que no campo narrativo o pesquisador se posicione, se politize nas relações de saberes e poderes. "A escolha desta posição narrativa (ethos da pesquisa/ethos da clínica) não pode ser encarada como desarticulada das políticas que estão em jogo: políticas de saúde, políticas de pesquisa, políticas da subjetividade, políticas cognitivas. Toda produção de conhecimento, precisamos dizer de saída, se dá a partir de uma tomada de posição que nos implica politicamente" (p. 150).

${ }^{8}$ Esta abordagem metodológica implica a participação dos sujeitos ativa e integral. O comprometimento do pesquisador é uma das características mais relevantes apontada por diversos pesquisadores de pesquisa intervenção. Monceau (2005) argumenta pela transformação das práticas para conhecê-las. Dadas às especificidades da temática abordada, compreendia-se a adequação desta orientação metodológica.
} 
conhecimento que encontra a possibilidade de "explorar dinâmicas sociais mais do que ações supostamente estáticas" (p. 467).

Menezes et. al. (2018) falam sobre o compromisso social e implicação pessoal com a justiça ético-política-científica no fazer da pesquisa. Scisleski et. al. (2008) destacam que uma dificuldade está imposta para os profissionais que lidam com as temáticas relacionadas à juventude a partir de uma lógica individualizante que subjetiva e produz subjetividades aos jovens. Existe, conforme as autoras, uma trama social que perpassa a temática da juventude. As autoras apresentam como possibilidade o posicionamento, na elaboração de pesquisas, de modo a analisar em que medida são tomadas como individuais questões que se referem à trama social, questionar o direcionamento exclusivo de argumentos e práticas para o indivíduo, e propondo um novo olhar, da perspectiva social (p. 343).

Compreendemos que esta dificuldade também pode se refletir nas estratégias tradicionais de pesquisa. Para ilustrar, podemos pensar que em determinado momento, pesquisador ou entrevistados formulem que "a família é responsável pela situação $X$ ". A proposta não-individualizante apresentada por Scisleski et. al (2008) tem a ver com problematizar essa responsabilização individual, e analisá-la do ponto de vista daquilo que é produzido socialmente, em tramas, isto é, em certa medida por relações complexas e, muitas vezes, conflituosas, da organização da sociedade e de seus discursos, ou nos atravessamentos dos fenômenos de saberes e poderes.

Deste modo, na presente pesquisa, pretendeu-se no que coube à inserção em campo, prioritariamente, o desempenho de atividades no coletivo, por meio de observação participante e encontros em grupo para entrevistas semiestruturadas, que se tornavam, ao longo de seu desenvolvimento, discussões sobre os temas trabalhados. 


\section{A pesquisa de campo}

A pesquisa realizada em campo partiu de considerações estabelecidas em etapa exploratória e levantamento de literaturas no tema estudado. A escolha pela Zona Sul como região pesquisada se relaciona a seus elevados índices de vulnerabilidades, entendeu-se da influência destes pensando o tema estudado. Carril (2006) afirma que:

A especificidade de certos fenômenos urbanos ao estudar como eles se relacionam com a sociedade em seu conjunto, com seus componentes sociais, econômicos e políticos, suas relações contraditórias presentes na vida cotidiana, que nada mais são do que o imediatos dos seres que habitam um espaço na cidade. $\mathrm{O}$ cotidiano encontra-se, assim, assentado nas relações próximas aos indivíduos: sentimentos, família, trabalho, sonhos, aspirações e frustrações; enfim, tudo aquilo que marca a existência humana na Terra" (CARRIL, 2006: 21).

De fato, a região Sul deu relevo a questões que implicam nos modos como se organizam as políticas, os sujeitos e as instituições, e garantiu relevância e especificidades - localidade - às discussões tratadas em campo e ora analisadas, pensando os altos índices de violência juvenil, mas também que as condições de vida dos sujeitos, em diferentes esferas, estão relacionadas aos fenômenos abordados.

A etapa exploratória da pesquisa consistiu na investigação preliminar, realizada através de estudos e pesquisas prévias ao campo acerca do tema da pesquisa, documentos, trabalhos acadêmicos e pesquisas relacionadas à juventude em conflito com a lei. Nesta etapa foram levantadas as principais questões a respeito do fenômeno, e a partir do entendimento dos diversos fatores que o envolvem, foi possível estabelecer de maneira mais objetiva os procedimentos a serem realizados em campo. A etapa exploratória serviu como base para a fundamentação teórica do trabalho.

A etapa de coleta de dados ocorreu de janeiro a agosto de 2018, nos distritos Capão Redondo e Jardim Ângela, (especificamente, nos bairros conhecidos como Fundão do Jardim Ângela), na região Sul do Município de São Paulo, junto a serviços 
de atendimento socioeducativo para cumprimento de medidas em meio aberto, conveniados à rede de proteção social especial da assistência social municipal. A escolha dos mesmos justifica-se de acordo com os indicadores sociais e disponibilidade dos serviços em colaborar com a pesquisa. O cronograma das visitas também seguiu, conforme disponibilidade da gestão e das equipes locais para atender ao pesquisador, sendo que a maioria das visitas aconteceu em dias da semana reservados pelos serviços para reuniões em equipe.

\section{Procedimentos e técnicas utilizadas em campo}

No primeiro momento, buscou-se agendamento de visita inicial às instituições, primeiro contato com objetivo de apresentação do pesquisador e do projeto, e a partir daí, havendo concordância dos gestores locais e dos participantes, organizaram-se as visitas posteriores. Nesta etapa, não houve utilização de gravador, recorrendo-se à observação semiestruturada ou observação participante.

Observação semiestruturada: dando conta, principalmente, dos territórios e do trajeto até os serviços, locais de parada, meios de transporte público, foi utilizada e registrada em todas as visitas. Minayo (2002) define a observação como "contato direto" do pesquisador com os fenômenos, com objetivo de obter informação diretamente em seus contextos (p. 59). A técnica utilizada em campo aqui é denominada por Laville e Dionne (2008) observação não-estruturada ou semiestruturada ou apenas observação participante, de modo que o pesquisador em campo não se baseia em guia ou protocolo do que deve focalizar sua atenção, podendo recorrer à tomada de notas 
descritivas e analíticas, como optamos, com vistas a não contar somente com o trabalho da memória (LAVILLE e DIONNE, 2008; BREAKWELL et. al., 2011).

Entrevistas Nas visitas posteriores, foram agendados encontros para realização de entrevistas. A maioria das entrevistas foi coletiva, dado o entendimento que questões comuns ligadas ao contexto institucional podem emergir, e tentando operar com lógicas não-individualizantes. As entrevistas coletivas duraram cerca de duas horas, e de fato tornavam a dinâmica do procedimento de entrevista em ricas discussões, por parte da interação entre os trabalhadores sobre os temas discutidos.

Há questões em torno do tema que não são vivenciadas ou percebidas por apenas este ou aquele trabalhador do sistema de medidas socioeducativas. Mas que estendem percursos compartilhados, tanto pelos jovens como pelos profissionais do sistema de medidas socioeducativas, "problemas", que despontam, são identificados e podem, no coletivo, ser discutidos e repensados.

Nesta pesquisa, foram utilizadas entrevistas semiestruturadas, individuais e em grupo, somente com os profissionais dos serviços de atendimento socioeducativo. Nesta modalidade, ainda que houvesse questões predeterminadas, é permitida abertura à espontaneidade dos sujeitos. Devido à configuração em grupos, houve maior liberdade dos diálogos. Nesse exercício de diálogo, também nos expomos por meio de apontamentos ou questionamentos, alguns destes apresentamos nos excertos dos diálogos transcritos.

Os temas das questões utilizadas no trabalho em campo foram:

1. Histórico da instituição e sua atuação no território. 
2. Experiência dos participantes de atuação com a juventude em atendimento socioeducativo (ou juventude, em geral). Há quanto tempo? Que mudanças percebe neste cenário?

3. Compartilhar algum caso que o participante tenha acompanhado e que the mobilizou.

4. Recomendações que o participante daria aos pesquisadores(as) que desejam compreender as dinâmicas do sistema socioeducativo.

Entrevista piloto: A entrevista piloto foi realizada em uma instituição que gere um projeto de arte-educação para jovens em cumprimento de medida em meio fechado (internação) nas unidades da Fundação Casa, órgão ligado à Secretaria de Justiça do Governo Estadual de São Paulo. Foram entrevistadas a gestora e uma das profissionais que atuam nesse projeto. As entrevistas foram feitas na sede da organização e não tivemos qualquer acesso aos jovens em cumprimento de medida em meio fechado, tampouco, em nenhum tempo houve qualquer atividade in loco na Fundação Casa.

A etapa "piloto" antecedeu a realização das entrevistas nos equipamentos nos demais territórios, e ofereceu um parâmetro sobre a qualidade das questões trabalhadas e do modo de interação com os participantes. 


\section{Sujeitos da pesquisa, territórios e organizações}

A pesquisa foi realizada com profissionais atuantes em 02 (duas) instituições da rede de atendimento de medidas socioeducativas em meio aberto (liberdade assistida e prestação de serviços comunitários) da Região Sul do Município de São Paulo.

Os entrevistados atenderam a encontros que ocorreram em seus próprios locais de trabalho. Foi priorizada a aplicação de entrevistas coletivas, sendo somente uma das entrevistas realizadas de forma individual, devido à necessidade de agenda com o profissional entrevistado, que foi o primeiro em seu setor acordando em participar, mas que estaria de férias quando da realização das entrevistas coletivas.

O único critério apresentado aos profissionais era sua participação por iniciativa própria, em um dos serviços, toda a equipe técnica esteve presente, no outro, alguns dos profissionais estavam realizando outras atividades e não puderam participar.

\section{O trabalho socioeducativo}

O trabalho desempenhado por essas equipes ocorre de acordo com o previsto nos instrumentos de proteção aos direitos dos adolescentes, principalmente no ECA e no SINASE, atende os jovens encaminhados principalmente pelo Poder Judiciário, nas faixas etárias de 12 a 21 anos (quando cumprem medida aplicada antes de completarem 18 anos de idade).

O sistema de medidas socioeducativas em meio fechado, no qual trabalham as duas profissionais que colaboraram na entrevista piloto, é desenvolvido pelo governo do Estado. Atende jovens encaminhados para cumprirem medidas privativas de liberdade de internação ou de internação provisória. Esse sistema é substitutivo ao modelo da 
FEBEM, busca em sua proposta realizar atividades educativas e formativas para os jovens internos, como frequência a cursos profissionalizantes e participação em oficinas de cidadania e arte-educação.

Já o sistema de medidas socioeducativas em meio aberto atende jovens em restrição de liberdades, encaminhados pelo Poder Judiciário com demandas específicas de "ressocialização". 14 dos profissionais entrevistados na pesquisa atuam neste sistema. A gestão desses serviços é municipalizada, conforme previsão do SINASE. Trata-se de serviço desempenhado, na cidade de São Paulo, por organizações da sociedade civil sem fins lucrativos, atuantes nos diversos territórios. A administração e o financiamento cabem à Prefeitura, por meio da Secretaria Municipal de Assistência e Desenvolvimento Social (SMADS), através de suas coordenadorias de Proteção Social Especial, e a supervisão da execução dos serviços é feita pelos Centros Especializados de Assistência Social (CREAS), junto aos distritos.

O trabalho envolve acolhimento dos jovens, quando egressos do sistema judiciário; a elaboração de um Plano Individualizado de Atendimento (PIA) em conformidade às medidas indicadas também pelo judiciário; o apoio e orientação ao jovem em atividades como retirada de documentos, busca de emprego, inscrição em cursos e matrícula escolar, inclusão em serviços de saúde e assistência social; atendimentos individuais para orientação e acompanhamento por um dos profissionais de nível superior referendados; atendimentos em grupo e realização de grupos de discussão temáticos e grupos de famílias; visitas domiciliares; atividades de lazer, entre outras. 


\section{Perfil dos participantes da pesquisa}

Foram entrevistados 16 profissionais (entre estes, 3 eram os gestores das respectivas equipes) que atuam em serviços de medida socioeducativa. A maioria dos participantes é do gênero feminino, embora 2 dos 3 gestores eram do gênero masculino. A média de idade entre os participantes é 34 anos de idade. A maior parte dos trabalhadores vive na Região Sul do Município, mesma região dos serviços em que atua.

As informações sobre o perfil foram colhidas a partir do questionário no instrumento assinado para consentimento à pesquisa (TCLE). Todos os participantes possuem nível superior completo, entretanto, no instrumento utilizado não foi perguntada sua área de formação, de modo que não dispomos da informação referente a todos os profissionais entrevistados, os que espontaneamente mencionaram o assunto são formados nas seguintes áreas: Ciências Sociais, Direito, Serviço Social, Pedagogia e Psicologia 9 . Outro critério importante que não constava no instrumento é a autodeclaração racial, embora consideremos esta informação de grande importância no contexto da pesquisa; ainda assim, cinco dos profissionais em seu discurso mencionaram sua autoidentificação enquanto negros, não tendo dados sobre os demais.

A tabela 3, a seguir, descreve os perfis dos entrevistados pelos seguintes critérios: sexo/gênero; autodeclaração de cor /raça; idade; região de residência; área de formação; e tempo de atuação no serviço de medidas socioeducativas de meio aberto:

\footnotetext{
9 Os serviços de medidas socioeducativas em meio aberto (SMSE/MA) seguem os parâmetros de composição de equipe técnica estabelecidos pela NOB/SUAS-RH indicados para o CREAS, e pelo Caderno de Orientações Técnicas de Serviço de Medidas Socioeducativas em Meio Aberto (MINISTÉRIO DO DESENVOLVIMENTO SOCIAL, 2009 e 2016). Nestes, consta a seguinte orientação de composição de equipe para CREAS (e seguida pelo SMSE/MA) em Municípios de grande porte, como é o caso de São Paulo, com capacidade de atendimento superior a 80 indivíduos e famílias, como os serviços visitados: 1 coordenador; 2 assistentes sociais; 2 psicólogos; 1 advogado; 4 profissionais de nível superior ou médio para abordagem; 2 auxiliares administrativos.
} 
Tabela 3: Perfil dos respondentes por sexo/ gênero; autodeclaração de cor/raça; idade; região de residência; área de formação; e tempo de atuação no serviço de medidas socioeducativas de meio aberto - São Paulo, 2018.

\begin{tabular}{|c|c|c|c|c|c|c|c|c|c|c|c|}
\hline $\begin{array}{l}\text { Por sexo/ } \\
\text { gênero }\end{array}$ & $(\%)$ & $\begin{array}{l}\text { Por } \\
\text { autodeclaração } \\
\text { cor /raça }\end{array}$ & $(\%)$ & $\begin{array}{l}\text { Por } \\
\text { idade }\end{array}$ & $\begin{array}{l}\text { (n) } \\
\text { (anos) }\end{array}$ & $\begin{array}{l}\text { Por região } \\
\text { de } \\
\text { residência }\end{array}$ & $(\%)$ & $\begin{array}{l}\text { Por área de } \\
\text { formação* }\end{array}$ & $(\%)$ & $\begin{array}{l}\text { Por tempo } \\
\text { de atuação } \\
\text { no atual } \\
\text { SMSE/MA }\end{array}$ & $(\%)$ \\
\hline Feminino & 56,2 & Negra & 31,2 & $\begin{array}{l}\text { Maior } \\
\text { idade }\end{array}$ & 44 & $\begin{array}{l}\text { Mesma } \\
\text { região do } \\
\text { trabalho }\end{array}$ & 50 & $\begin{array}{l}\text { Ciências } \\
\text { sociais }\end{array}$ & 12,5 & $\begin{array}{l}\text { Menos de } 1 \\
\text { ano }\end{array}$ & 31,2 \\
\hline \multirow[t]{6}{*}{ Masculino } & \multirow[t]{6}{*}{43,8} & \multirow[t]{6}{*}{ Não informado } & \multirow[t]{6}{*}{68,8} & $\begin{array}{l}\text { Menor } \\
\text { idade }\end{array}$ & 24 & $\begin{array}{l}\text { Outra } \\
\text { região }\end{array}$ & 37,5 & Comunicação & 6,2 & $\begin{array}{l}\text { De } 1 \text { a } 2 \\
\text { anos }\end{array}$ & 31,2 \\
\hline & & & & $\begin{array}{l}\text { Média } \\
\text { idade }\end{array}$ & 34,7 & $\begin{array}{l}\text { Outro } \\
\text { município }\end{array}$ & 12,5 & Direito & 6,2 & $\begin{array}{l}\text { De } 2 \text { a } 4 \\
\text { anos }\end{array}$ & 6,2 \\
\hline & & & & & & & & Pedagogia & 12,5 & $\begin{array}{l}\text { De } 4 \text { a } 6 \\
\text { anos }\end{array}$ & 12,5 \\
\hline & & & & & & & & Psicologia & 12,5 & $\begin{array}{l}\text { De } 6 \text { a } 9 \\
\text { anos }\end{array}$ & 18,8 \\
\hline & & & & & & & & Serviço social & 12,5 & & \\
\hline & & & & & & & & $\begin{array}{l}\text { Não } \\
\text { informado }\end{array}$ & 37,5 & & \\
\hline
\end{tabular}

* A composição das equipes técnicas dos serviços SMSE/MA, no Município de São Paulo, quanto aos profissionais de nível superior, estes são contratados como "Técnicos sociais" ou "Técnicos socioeducativos", independentemente de sua área de formação.

\section{Organizações e territórios de abrangência}

Em respeito a preocupações que surgiram durante as entrevistas, optou-se por não revelar os nomes das organizações que colaboraram nesta pesquisa. Dessa forma, para efeitos de distinção, serão descritas pelas siglas "OSC" 1, 2 e 3, seguida de uma breve descrição de suas atuações e territórios de abrangência.

- OSC-1 - A organização da sociedade civil (OSC) 1 desenvolve importantes projetos educativos e arte-educativos. Colaborou com esta pesquisa na entrevista-piloto, o motivo de sua participação é o desenvolvimento de projetos junto ao sistema estadual 
de medida socioeducativa em meio fechado (internação). Foram feitas duas visitas à OSC1, no primeiro semestre de 2018.

Desde o ano de 2008, a Fundação Casa realiza parcerias com entidades da sociedade civil para o desenvolvimento de projetos de arte e cultura para os jovens em cumprimento de medidas socioeducativas de internação e semiliberdade. Neste âmbito, a OSC1, em um de seus principais projetos, atua em 19 unidades da Fundação Casa em todo o Estado de São Paulo, promovendo oficinas de arte-educação para adolescentes, além de formação e acompanhamento dos arte-educadores. Duas profissionais (uma educadora e a gestora) foram entrevistadas em março de 2018.

- OSC2 - Região Capão Redondo - esta organização tem grande atuação junto aos movimentos sociais de moradia na região Sul do Município de São Paulo. Atua também, em parceria com a SMADS, junto à gestão de diferentes modalidades de serviços socioassistenciais municipais. Foram realizadas quatro visitas à OSC2, no período de janeiro a agosto de 2018, e oito dos colaboradores desta entrevista são desta OSC2. No território selecionado, o serviço é gerido pela OSC2, que atua há cerca de 10 anos no serviço. À época das visitas, atendia aproximadamente 80 jovens inscritos e suas famílias, residentes dos bairros e comunidades do Capão Redondo e adjacências.

Território abrangente ao serviço: Estância Pirajussara; Jardim Alvorada; Jardim Amália; Jardim Ana; Jardim Comercial; Jardim das Rosas; Jardim Dinah; Jardim Dom José; Jardim Eledy; Jardim Emilia; Jardim Iae; Jardim Irapiranga; Jardim Irene; Jardim Jerivá; Jardim Lilah; Jardim Macedonia; Jardim Magdalena; Jardim Marciano; Jardim Mirante; Jardim Soraya; Jardim Valquíria; Parque Aliança; Parque do Engenho; Parque 
Fernanda; Parque Rondon; Parque Sonia; São Bento Novo; Valo Velho; Vila Clélia; Chácara Santa Maria; Cohab Adventista; Conjunto Habitacional Chico Mendes.

- OSC3 - Região Fundão do Jardim Ângela - assim como o serviço anterior, este equipamento presta serviços em conformidade às políticas de assistência social, e é referência a aproximadamente 120 jovens inscritos e suas famílias, residentes nas comunidades e bairros da região conhecida como "Fundão do Jardim Ângela", localizada numa das extremidades ao sul em área de preservação de mananciais próximas à Represa Guarapiranga. O serviço é gerido pela OSC3, entidade católica, que atua em projetos sociais e em parceria com serviços da SMADS, em distritos periféricos na região Sul do Município. Foram feitas três visitas à OSC3, período de janeiro a junho de 2018 e entrevistados seis de seus profissionais.

Território abrangente ao serviço (divisão oficial): Alto do Riviera; Chácara Santa Maria; Conjunto Habitacional Paranapanema; Estância Mirim; Jardim Aracati; Jardim Capela; Jardim Guaruja; Jardim Horizonte Azul; Jardim Nakamura; Jardim Ranieri; Jardim São Lourenço; Jardim Solange; Jardim Turquesa; Jardim Vera Cruz; Morro do Índio; Parque Bologne; Parque das Cerejeiras; Parque do Lago; Parque Independência; Vila Calú; Vila Gilda; Vila Santo Amaro.

\section{Análise dos dados}

Laville e Dione (2008) apontam que o trabalho de análise se inicia nas etapas de pesquisa anteriores e inicia sua consolidação a partir da organização do material empírico colhido. "À medida que colhe informações, o pesquisador elabora sua 
percepção do fenômeno e se deixa guiar pelas especificidades do material selecionado" (p. 215). Este trajeto que perfaz a consolidação de material e inicia o processo de análise ainda em campo é acompanhado pela distinção em categorias significativas para classificar os conteúdos.

A análise de conteúdo não é, contudo, um método rígido, no sentido de uma receita com etapas bem circunscritas que basta transpor em uma ordem determinada para ver surgirem belas conclusões. Ela constitui, antes, um conjunto de vias possíveis nem sempre claramente balizadas, para a revelação - alguns diriam reconstrução - do sentido de um conteúdo" (LAVILLE e DIONE, 2008: 216).

Oscar Jara Holiday (2006) trata de uma "concepção metodológica dialética" aquela em que se aproxima da realidade para conhecê-la e transformá-la. A concepção de dialética entre prática e teoria que este autor busca para promover a técnica que denomina "sistematização", sendo definida como um exercício de aprendizagem que permite "interpretação crítica dos processos vividos" a partir da reflexão sobre as experiências (HOLLIDAY, 2006: 49).

Assim, cada retorno das visitas em campo potencialmente mobiliza diversos conceitos. Os conceitos, ainda que elaborados em todas as etapas do ordenamento do ciclo de pesquisa, antes, durante e após a inserção empírica. O acontecimento em campo, contudo, produz a mudança no pesquisador e nos sujeitos, pois se constatam diante da situação discutida, e podem se questionar os possíveis sentidos desta, o que esperar ou como atuar sobre a mesma. Questões que emergem a partir do diálogo entre pesquisador e interlocutores, e dinamizam os dados e termos teóricos, impulsionando-os com os sentidos da realidade social. 


\section{Instrumentos de análise}

Na elaboração deste trabalho, recorremos a excertos dos registros de atividade de campo e das transcrições das entrevistas.

Registros de atividades de campo: Como ferramenta para análise do material, realizávamos, a cada visita a campo, independentemente da finalidade, registros de atividade de campo em formato de relatório, de modo a dar suporte qualitativo à análise dos eventos ocorridos.

Nos registros realizados, eram anotados os seguintes itens: i) Data; ii) Tipo de atividade (isto é, a finalidade daquela visita: apresentação, entrevistas); iii) Local da atividade; iv) Relatório descritivo e impressões do pesquisador, e v) Palavras-chave. A separação por palavras-chave foi importante, de modo a criar "marcadores" temáticos, que facilitavam quando postos em comparação com as transcrições. Na etapa de análise de todo material colhido, auxiliam na emergência das categorias de campo.

Além disso, buscávamos incrementar os registros com pesquisas sobre temas anunciados, como matérias jornalísticas e textos pesquisados na Internet a partir de elementos mencionados, extraídos em campo. Por exemplo: soubemos, em campo, a respeito do Centro Integrado de Educação de Jovens e Adultos - CIEJA Campo Limpo. Posteriormente, no momento de escrita dos Registros, buscamos mais informações a respeito deste serviço, complementando o banco de dados acerca do território.

Transcrição: $\mathrm{O}$ trabalho de transcrição foi feito em duas etapas. Na etapa preliminar, foram demarcados os assuntos (temas) abordados, que por fim orientariam as categorias mais relevantes, ou seja, aquelas mais abordadas pelos participantes nas entrevistas. A segunda etapa consistiu na transcrição ipsis litteris das entrevistas e diálogos realizados. Por exemplo: retomando os áudios, em dado momento, o 
profissional fala sobre o trabalho para os jovens, e os demais profissionais passam também a discorrer sobre este tema, ampliando-o. Na transcrição, em um primeiro momento, destacamos "Trabalho", enquanto categoria de relevância para análise. No momento posterior, transcrevemos o diálogo literalmente como ocorreu.

Os registros de campo somados às transcrições resultaram em 122 páginas.

\section{Categorias de análise}

A partir dos dados recolhidos em campo, pensamos nas categorias de análise, apresentadas conforme Quadro 1 a seguir, para organizar as discussões:

\begin{tabular}{|c|c|c|c|c|}
\hline \multicolumn{5}{|c|}{ Quadro 1: Categorias e subcategorias de análise } \\
\hline Categorias & Territórios & $\begin{array}{c}\text { Trabalho } \\
\text { (mercado), } \\
\text { sociedade e } \\
\text { Estado na MSE }\end{array}$ & $\begin{array}{c}\text { O trabalho } \\
\text { socioeducativo, } \\
\text { seus sujeitos, } \\
\text { políticas e } \\
\text { serviços }\end{array}$ & $\begin{array}{l}\text { Políticas sociais, } \\
\text { famílias e } \\
\text { afetividade }\end{array}$ \\
\hline Subcategorias & $\begin{array}{l}\text { - O conceito de } \\
\text { hiperperiferia; } \\
\text { - Capão Redondo; } \\
\text { - Fundão do } \\
\text { Jardim Ângela }\end{array}$ & $\begin{array}{l}\text { - As drogas na } \\
\text { periferia; } \\
\text { - As dimensões } \\
\text { de trabalho no } \\
\text { território; } \\
\text { - A ação } \\
\text { policial; } \\
\text { - A morte na } \\
\text { periferia e a } \\
\text { "vida nua"; } \\
\text { - Valores do } \\
\text { ECA e os } \\
\text { valores da } \\
\text { sociedade; } \\
\text { - Precarização } \\
\text { das políticas } \\
\text { sociais }\end{array}$ & $\begin{array}{l}\text { - Os } \\
\text { trabalhadores; } \\
\text { - As instituições } \\
\text { e o trabalho "em } \\
\text { rede"; } \\
\text { - O papel } \\
\text { privativo de } \\
\text { liberdade da } \\
\text { MSE/MA; } \\
\text { - As relações } \\
\text { semânticas entre } \\
\text { "menino" } \\
\text { "bandido"; } \\
\text { - O "envolvido"; } \\
\text { - Discursos e } \\
\text { abordagens } \\
\text { sobre a questão } \\
\text { racial na MSE }\end{array}$ & $\begin{array}{l}\text { - A MSE como } \\
\text { possibilidade } \\
\text { afetiva; } \\
\text { - Conceitos de } \\
\text { trabalho } \\
\text { socioeducativo e } \\
\text { vínculos sociais; } \\
\text { - Infracionar } \\
\text { para incluir; } \\
\text { - Histórias de } \\
\text { mães, pais, } \\
\text { famílias, do } \\
\text { Estado e seus } \\
\text { agentes }\end{array}$ \\
\hline
\end{tabular}

Do autor, 2019. 


\section{Histórias em vez de casos, narrativas e devires}

[Entrevistada 9] - Eu acho que todos (os casos) afetam. Acho que, de uma maneira geral, a gente se sente afetada sempre. Cada história, a gente fala caso, mas tem uma história, são pessoas, né?

A fala extraída do relato da entrevistada aponta-nos um caminho para a compreensão que, para além do diálogo acadêmico-científico, não se tratam somente de questões sociais narradas, mas, em primeiro lugar, da vida de pessoas. A técnica entende que, sendo mais histórias que casos, como tendemos a tratar nas discussões acadêmicas e científicas, é possível destacar, "lembrar" que ali, detrás da discussão, há pessoas.

Dito isto, seguem nesta pesquisa sob a nomenclatura de "histórias", narrações de episódios de vidas. Sujeitas e sujeitos que vivenciam as vulnerabilidades e violações de direitos tratadas aqui, mas que são mais do que poderíamos falar a respeito de si. Que estabelecem contratos, têm desejos, virtudes, cometem erros e infrações à lei, que se articulam, lutam, amam, resistem, têm objetivos que são alcançados ou frustrados. Que dispõem de dimensões que estão para além do conflito com a lei e sua relação com o Estado e seus agentes, de uma ordem dinâmica que é própria da vida, portanto, mais profunda, mais legítima e menos breves do que propõe nossa abordagem.

Mais que isso, os personagens que protagonizam tais histórias não são tampouco tais histórias. Estão sendo "contados" pelos profissionais e ora recontados neste trabalho.

Foucault (1996) fala sobre a "vontade de verdade" que emerge nos discursos na produção de saberes e conhecimentos. Por meio desta, busca-se o "discurso verdadeiro", que se insira e se desloque nas relações de poder (p. 20). Esse deslocamento de poder que circula na produção de saberes é um dos grandes interesses da obra foucaultiana, o 
autor dirá que essa vontade de verdade constitui um sistema historicamente localizado, produtor de exclusões. Sutilmente, as tecnologias discursivas produtoras de verdades e "não-verdades" é capaz de mascarar essa vontade de verdade que as engendram, as mesmas que perfazem o saber acadêmico. "O discurso verdadeiro, que a necessidade de sua forma liberta do desejo e libera do poder, não pode reconhecer a vontade de verdade que o atravessa; e a vontade de verdade, essa que se impõe a nós há bastante tempo, é tal que a verdade que ela quer não pode deixar de mascará-la" (FOUCAULT, 1996: 18).

Cada sociedade tem seu regime de verdade, sua "política geral" de verdade: isto é, os tipos de discurso que ela acolhe e faz funcionar como verdadeiros; os mecanismos e as instâncias que permitem distinguir os enunciados verdadeiros dos falsos, a maneira como se sanciona uns e outros; as técnicas e os procedimentos que são valorizados para a obtenção da verdade; o estatuto daqueles que têm o encargo de dizer o que funciona como verdadeiro (FOUCAULT, 2010:12).

Por outro lado, Passos e Benevides (2009) tratam de uma escolha metodológica a partir de um ethos na pesquisa em saúde, "os dados coletados a partir de diferentes técnicas $[. .$.$] indicam maneiras de narrar - seja dos participantes ou sujeitos da pesquisa,$ seja do pesquisador ele mesmo - que apresentam os dados, sua análise e suas conclusões segundo certa posição narrativa" (p. 150).

Esses autores propõem o investimento numa política de narratividade, definida a seguir:

Podemos pensar a política da narratividade como uma posição que tomamos quando, em relação ao mundo e a si mesmo, definimos uma forma de expressão do que se passa, do que acontece. Sendo assim, o conhecimento que exprimimos acerca de nós mesmos e do mundo não é apenas um problema teórico, mas um problema político.

Barbosa (2004) nos apresenta uma definição para o uso da narrativa por meio da noção de experiência de acontecimento: "Acontecimento seria algo que emerge na duração, irrompendo a cena e estabelecendo uma distinção entre aquele instante e o imediatamente anterior" (p. 7). Esta autora, de fato discorre sobre o uso da narrativa em 
um "regime de visualidade", que é instaurado pela modernidade com a emergência da televisão. Prado et.al. (2014) falam do sentido teórico-metodológico das narrativas nas pesquisas: "a narrativa como fonte de dados, como método de análise e/ou registro do trabalho de pesquisa". Ou seja, as pesquisas podem utilizar a narrativa como fontes dos dados, como meio de registro do percurso ou no modo de produção de conhecimento. Ainda em Barbosa (2004), é importante destacar que a construção de uma narrativa passa pela "renarrativação do mundo, inscrita no tempo por obedecer a uma temporalidade construída, em que ordem, duração e frequência são constantes” (p. 19). Nessa concepção, as narrativas remetem, ao mesmo tempo, à experiência do narrador e do ouvinte / leitor e aos acontecimentos narrados situados espacial e temporalmente. $\mathrm{O}$ conceito de narrativa é descrito, a princípio pelo pensador Walter Benjamin (1987), que afirma que a narrativa "não está interessada em transmitir o 'puro em si' da coisa narrada como uma informação ou um relatório. Ela mergulha a coisa na vida do narrador para em seguida retirá-la dele" (p. 205).

Na presente análise, evidencia-se a opção pela narrativa como método de análise e fonte de dados, de forma que, longe de pensar a "vontade de verdade" a qual denuncia Foucault, propõe-se captar algo que se apresenta no devir, conceito que o antropólogo João Biehl extrai do pensador Gilles Deleuze, e implica na metodologia das pesquisas sociais, afirmando que a atenção "aos devires humanos nos ajuda a ver o que está emergindo no campo: as microdinâmicas das vidas humanas que iluminam novas configurações de pensamento, estados afetivos e solidariedades que podem criar rasgos e aberturas, mesmo que pequenos, nas macrorrealidades sociais e políticas" (SCHUCH, 2016: 396; BIEHL, 2008). 
Esses casos-narrativas-devires-histórias, aqui recontados, têm o nome de seus sujeitos preservados por questões éticas. Buscamos associar os nomes dados a elementos, entidades e divindades das culturas e tradições afro-brasileiras, no intento de aludir que se tratam de jovens e famílias negras seus correlatos da vida real.

A princípio os profissionais entrevistados são identificados por número de organização de suas falas, preservando suas identidades. Sendo anunciados como [Entrevistado] ou [Entrevistada] mais um numeral indicando essa ordem criada pelo entrevistador, por vezes a transcrição de suas falas aponta um diálogo, sendo posicionadas como tal.

Quando se trata de um diálogo narrado, um diálogo "de si”, ou seja, o entrevistado anuncia as falas de um interlocutor distante, essas falas são marcadas em itálico e entre aspas.

Por exemplo: [Entrevistado] O jovem me falou: "amanhã retorno ao meio dia”. Porém não retornou.

Os apontamentos e intervenções do pesquisador nos diálogos são apresentados entre colchetes.

Por exemplo: [Entrevistado] - O jovem me falou: "amanha retorno ao meio dia". Porém não retornou.

[E você ligou pra ele?]

[Entrevistado] - Liguei, mas ninguém atendeu.

Os excertos que remetem aos registros de campo são apresentados iniciados por "[Registro]", precedendo a descrição do registro de campo, geralmente escritos na primeira pessoa do singular. 


\section{Aspectos éticos}

A presente pesquisa foi submetida ao Comitê de Ética da Faculdade de Saúde Pública, (CAAE: 91030218.0.0000.5421), e aprovada por meio do Parecer 2.728.264.

Foram utilizados como instrumentais Termos de Consentimento Livre e Esclarecido (TCLE), apresentados em duas vias, sendo uma via disponibilizada para os entrevistados e a outra para o entrevistador, e a coleta de dados ocorreu com a ciência e anuência das instituições que colaboraram, subscrito pelos gestores em instrumental de anuência. Estes instrumentais se encontram nos Anexos do presente trabalho.

A pesquisa apresentou risco mínimo aos sujeitos, como possíveis desconfortos durante realização de entrevistas, tendo sido evitados pelo pesquisador.

Ressalta-se a preservação dos nomes dos sujeitos, em respeito ao sigilo das informações colhidas em campo. 


\section{Capítulo 4. TERRITÓRIOS: CAPÃO PECADO, ÂNGELA VERTIGEM}

Neste tópico serão discutidos, tendo anotações dos Registros de Campo aliados à bibliografia: os processos de constituição das periferias na Zona Sul de São Paulo. Dada à relevância dos territórios na vida dos sujeitos, estes se tornam, a partir da leitura que faremos, também sujeitos. Sujeitos de história, sujeitos que se relacionam, desejam, ocupam. Também vivos. Fazendo o que podem e o que não pode. Trajetos que descrevem corpos, que acompanham sentenças, que produzem morais distintas e muitas vezes concorrentes, limites, transgressões e infrações. E afetos.

Carril (2006) afirma que "a especificidade de certos fenômenos urbanos" nada mais é que suas relações contraditórias, presentes no cotidiano dos seres que habitam um espaço na cidade. Cotidiano "assentado nas relações próximas aos indivíduos: sentimentos, família, trabalho, sonhos, aspirações e frustrações; enfim, tudo aquilo que marca a existência humana na Terra" (p. 21). Aproximando-nos da proposta apresentada por Biehl de um fazer científico que atenta ao devir, que entende que "a atenção somente aos sistemas esquece ou não dá conta de alguma coisa crucial, que é o afeto, o sentimento, o relacional" (SCHUCH, 2016: 419; BIEHL, 2008); aproveitamos na composição deste tópico de duas referências literárias: os romances "Capão Pecado" (Ferrez, 2005) e "Um Sopro de Vida: Pulsações" (Lispector, 1999) ${ }^{10}$, estes aliados à literatura acadêmica acerca da Região Sul de São Paulo, e em diálogo com produções culturais regionais, como o rap, hip hop e o funk, tomamos também a licença, não pra "poetizar", "romancear" a descrição, de modo que a descaracterizaria, revestindo de

\footnotetext{
${ }^{10}$ Cabe pontuar que Ferrez (2005) escreve especificamente sobre o Capão Redondo, região onde viveu e participa de um movimento literário considerado "literatura marginal", por tratar da vida em regiões periféricas. Não se pode dizer o mesmo sobre Lispector (1999) que, provavelmente, não conhecia o Jardim Ângela e o nome de sua personagem não tem, a princípio, qualquer ligação regional. E a aproximação entre esses romancistas acontece aqui somente pela opção do pesquisador.
} 
fantasia suas especificidades; mas para demonstrar seu potencial mobilizador no que há de vivo e afetivo.

Os sujeitos do Ângela e do Capão. Os sujeitos Ângela e Capão, como se fossem nomes próprios, substantivos adjetiváveis, Pecado, "lugar esquecido por Deus e abençoado pelo diabo" (Ferrez, 2005), “o lugar mais perigoso do mundo”, Vertigem, "fundo do mundo", "Fundão", Vertigem, "povoamento e ermo" (Lispector, 1999). Capão Redondo e Fundão do Jardim Ângela. Pecado e Vertigem. Forças da Natureza.

Stürmer e Costa (2017) destacam que o conceito de território é original da Geografia, sendo utilizado por diversas outras áreas, muitas vezes em diferentes sentidos. O geógrafo Milton Santos (2007) define território como “o lugar em que desembocam todas as ações, todas as paixões, todos os poderes, todas as forças, todas as fraquezas, isto é, onde a história do homem plenamente se realiza”. Milton Santos compreende que a relevância da noção de território confere também à geografia sua "era de ouro", "porque a geograficidade se impõe como condição histórica (...) a partir do conhecimento do que é território" (p. 13). Este autor estabelece ainda duas formas de compreensão desenroladas a partir do conceito, que resultam num hibridismo conceitual próprio da Modernidade, o "território em uso" e o "território em si", explica que "o território são formas, mas o território usado são objetos e ações” (Santos, 1998: 16), "usado o território é humano" (p. 18). Santos é responsável por oferecer uma “conotação social” ao conceito de território, "o território de que se fala já não diz respeito somente àquele dos documentos oficiais", como mapas e medidas, torna-se expressão de fenômenos sociais (STÜRMER E COSTA, 2017).

No Brasil, o conceito de território figura nas políticas dos Sistemas Únicos de Saúde (SUS) e Sistema Único de Assistência Social (SUAS), distingue estratégias de 
gestão regionais e direciona ações e recursos num sentido localizado. Compreende-se que o território emerge como sujeito político, conforme a definição de Schuch (2014), pela qual "um sujeito político" torna-se "fundamental para a mobilização de práticas de governo, mas também de luta por recursos, reputações e novas posições sociais".

Borelli (2012) trata dos movimentos organizacionais periféricos da Zona Sul de São Paulo, decorrentes, em partes, de tendências migratórias entre os anos 1970 e 1980, com vistas à ocupação dessas regiões, consideradas zonas de preservação ambiental e proteção de mananciais. No entanto, essas regiões são ainda mais antigas, sendo observáveis ondas de migração que constituem as periferias da cidade como ora as conhecemos. Um dos motivos que impulsionaram e impulsionam esses movimentos ocupacionais é o valor demandado para acesso à moradia, isto é, diretamente, relacionado à especulação imobiliária no Município. Desta forma, a procura "por habitação em áreas com baixo preço da terra" leva a um "aumento de ocupações precárias, como favelas e loteamentos irregulares em áreas sem infraestrutura e expostas a risco e à degradação ambiental". Este movimento seria duplo, uma vez que produz e/ ou agrava mutuamente riscos à população ocupante e ao ambiente. De modo que a dinâmica da ocupação ilegal dessas regiões "faz com que grande parte das áreas de risco e proteção ambiental, tais como as margens dos cursos d'água, esteja ameaçada pelas ocupações precárias de uso habitacional de baixa renda, por absoluta falta de alternativas habitacionais" (BORELLI, 2012).

Esta transição incompleta urbano-manancial chama atenção para quem perfaz os trajetos das regiões centrais até o Capão Redondo, seguindo até a região conhecida como Fundão do Jardim Ângela. Nesta última, principalmente, observa-se constantemente, mesmo de nosso olhar leigo, o "risco" de eventuais desabamentos, uma 
constante ameaça de desorganização do cenário urbano feito num arranjo entre as regiões que margeiam a represa. Somam-se a esse "risco" os demais que muitas vezes são mais imaginários que presentes, mas que cartografam as periferias da Zona Sul moralmente nos registros do pânico. Nas incursões de campo, ao voltar do Fundão do Jardim Ângela, nos indagávamos "como pode se viver o tempo todo em risco"?

Spink (2014) pesquisa "os sentidos do risco no cotidiano", percebidos pelos moradores da região do Jardim Ângela. E destaca, a partir de conceitos das geociências, os seguintes fatores a respeito das áreas de risco: a suscetibilidade, definida pela propensão do solo à instabilidade, decorrente de características geomórficas e geológicas; e a vulnerabilidade, definida pela predisposição das pessoas e construções a serem afetadas na ocorrência de acidentes.

\section{Hiperperiferia - Afinal, periferia é periferia em qualquer lugar?}

Borelli (2012) argumenta ainda sobre a homogeneidade distributiva de determinados marcadores socioeconômicos e ambientais que, segundo a autora, "são exatamente as populações menos favorecidas, por características de renda, escolaridade, cor, gênero, que residem ou utilizam os territórios de maior vulnerabilidade ambiental que se superpõem à vulnerabilidade social” (p. 66).

As regiões Leste e Sul do Município de São Paulo concentram o maior número de favelas e ocupações. Borelli (2012) se vale do conceito de "hiperperiferia" para tratálas, uma vez que, não somente possuem disposição geográfica de relevância em comparação com o tamanho do Município, apresentam ainda zonas de "segregação da segregação" (p. 64), ou seja, no interior das comunidades observam-se camadas de mais alta vulnerabilidade, falta de acesso a equipamentos, e menores condições 
socioeconômicas. É o que se pode observar no território conhecido como "Fundão do Jardim Ângela", extremidades que se estendem até as margens da Represa Guarapiranga.

Carril (2006) define a concepção de hiperperiferia como um processo de formação de regiões, no interior de territórios de vulnerabilidade e de pobreza, ocupados por sujeitos e famílias que não puderam acessar as habitações e terrenos nos espaços considerados pela "valorização do bairro urbanizado".

A concepção de hiperperiferia, nesse sentido, significa a formação de bolsões de pobreza compostos por famílias que não puderam pagar pela valorização do bairro urbanizado. Na prática, denota que a população foi sendo empurrada cada vez mais para espaços de miséria, levada à imobilidade espacial devido à falta de recursos financeiros até para pagar o transporte, numa tendência de confinamento territorial (CARRIL: 2006:144).

Ainda no interior dos territórios periféricos, ocorrem declívios de acesso aos processos de urbanização e acesso, distribuídos seguindo condições de aquisição, principalmente. Ou seja, apesar de existirem homogeneidades nas desigualdades e similaridades socioeconômicas; existem ainda processos que agravam estas, produzindo camadas "hiperperiféricas" em regiões focais e extremos dos territórios periféricos, estes terrenos, agrupamentos e habitações são encontrados tanto no Capão Redondo, como no Jardim Ângela, sobretudo nas regiões de "aprofundamento das favelas", “fundão", como são chamados pelos moradores.

Apesar de Borelli (2012) propor uma “caracterização das periferias urbanas como locais relativamente homogêneos, em termos de falta de investimentos públicos, de acesso a bens e serviços essenciais, além de indicadores socioeconômicos com maus resultados" (p. 65); foi possível, a despeito disto, observar que "periferia" não é igual em "qualquer lugar", ainda que este seja o título de uma das músicas dos Racionais $M C$ 's, mais popular grupo musical de rap paulistano, originado no Capão Redondo. 
Capão e Ângela possuem diferenças estruturais, que, provavelmente, estão relacionadas aos seguintes fatores: i) o histórico de sua ocupação; ii) a mobilização dos agentes políticos locais; iii) distância geográfica e de meios de acesso com relação ao centro do Município; iv) forma de exploração dos recursos ambientais locais; e, v) a visibilidade adquirida pela região e as respostas em termos de investimentos políticos estatais, diretamente relacionadas aos fatores precedentes.

Carril (2006) descreve em sua obra que um novo padrão de organização espacial se torna presente em São Paulo a partir das consequências de "mudanças no padrão tecnológico, com base na reestruturação produtiva e na flexibilização industrial". Desse modo, São Paulo se expande enquanto cidade pela constituição de novos centros, e a consequente constituição de bairros periféricos, num "processo de favelização contínuo" (p. 107). De modo que os modelos centro-periferia que marcam a ocupação da cidade passam por transformações.

Desde os anos 1970, São Paulo atravessa uma dispersão e desconcentração de atividades industriais em favor de centros urbanos em cidades menores e mais interioranas. Dessa forma, uma "nova centralidade urbana" ocorre, entre os anos 1980 e 1990, um processo que parece ainda estar se desenvolvendo, o estabelecimento de empresas e corporações, muitas delas de operações internacionais, para a Região Sul da cidade, "compondo uma paisagem de contraste entre a moderna face do capitalismo globalizado e bolsões de pobreza e de riqueza, escassez e prosperidade" (CARRIL, 2006: 108).

Entende-se que regiões específicas da periferia, enquanto compartilham resistem e/ou persistem em espaços estratégicos de desenvolvimento, passam a dispor de meios de acesso outrora restritos, como asfaltamento, serviços de água e esgoto e instalações 
elétricas, serviços de comunicação e transporte, entre outros. O fenômeno não é necessariamente novo, conforme ressalta Carril (2006), mas sim uma transformação ou adaptação de processos de desigualdades urbanas inerentes às dinâmicas exigências do capital global, "os lugares demarcam relações intrínsecas às estruturas e forças econômicas capitalistas que tornaram viável o processo de valorização do espaço, ou seja, a apropriação do espaço público pelo privado" (p. 108). No entanto, essa distribuição de meios de acesso não ocorre de maneira total, abrangendo a espacialidade periférica por completo. Produzem-se descontinuidades significativas do desenvolvimento, de modo que uma ou duas ruas acima ou abaixo podem não contar com os mesmos serviços que casas ou prédios da vizinhança.

Carril pontua que os padrões de segregação espacial urbana no Município de São Paulo são ainda mais sintomáticos quando se levam em conta os processos históricos de ocupação das regiões periféricas, como é o caso do Capão Redondo e do Jardim Ângela, abordando ainda particularidades étnicos-raciais associadas ${ }^{11}$. Os mapas da ocupação da cidade como um todo confirmam a tendência apontada pela autora de um processo de segregação racial onde a ocupação das periferias do Município é predominantemente negra.

\footnotetext{
${ }^{11}$ Carril utiliza o conceito de "quilombo urbano", extraído da cultura musical rapper / hip hop brasileira, a autora afirma que "a identificação da periferia com o quilombo", apresentada em suas pesquisas pelas manifestações culturais das cenas periféricas na Zona Sul de São Paulo, traça um movimento que leva a população negra em São Paulo "da Senzala à periferia", tratando das "muitas semelhanças [...] entre a escravidão e a vida contemporânea da população negra na metrópole. Daí delineia-se o caráter de unidade dos processos sociais e econômicos que a cidade apresenta" (CARRIL, 2006: 22).
} 
Figura 3: Mapa da população do Município de São Paulo por raça e cor - São Paulo, 2010

Escala:

$>1 \%$ a $19,9 \%$ de população

residente preta e parda;

$>20 \%$ a $39,9 \%$ de população

residente preta e parda;

$>40 \%$ a $49,9 \%$ de população

residente preta e parda;

$>$ mais de $50 \%$ de população

residente preta e parda;

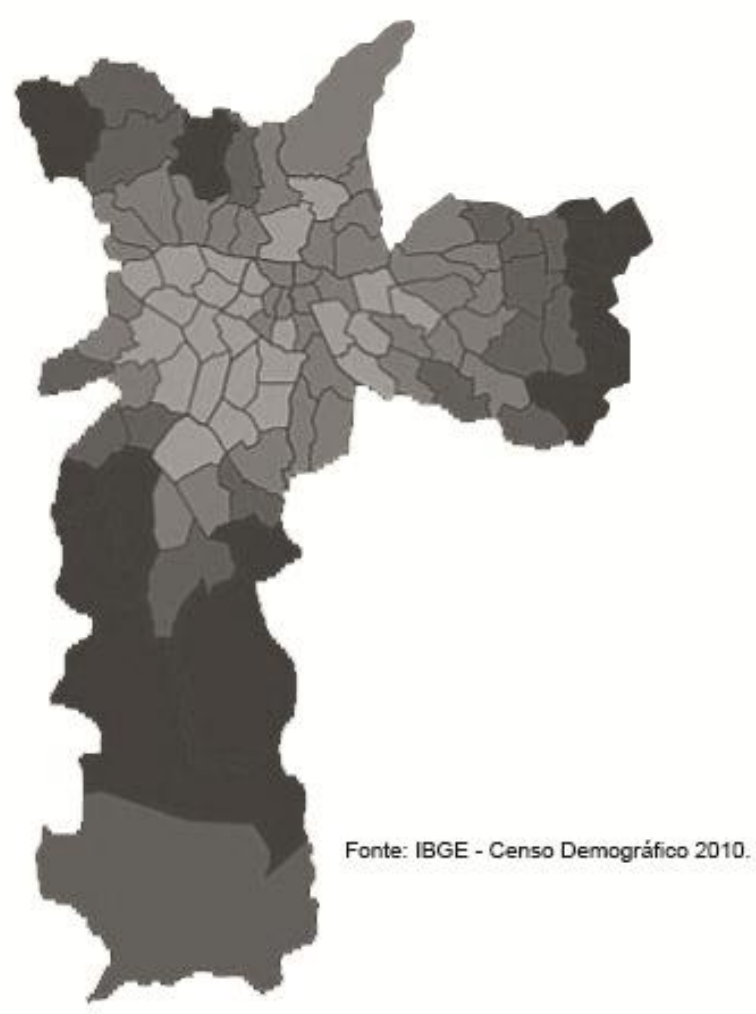

Fonte: REDE NOSSA SÃO PAULO, 2017.

A região da Zona Sul de São Paulo é equivalente às prefeituras regionais de Capela do Socorro, de Campo Limpo, de Cidade Ademar, de Parelheiros, e do M'Boi Mirim. É a maior do Município, contando com uma área de $687 \mathrm{~km}^{2}$, que equivale a 45,5\% do território municipal. Seus distritos figuram também nas estatísticas de desigualdade e altos índices de violência, além disso, possui grandes números de famílias residentes em favelas. A vulnerabilidade territorial é, portanto, um dos aspectos iniciais a serem levados em conta, quando as regiões são abordadas em pesquisas. 
Borelli (2012) define vulnerabilidade ambiental (territorial) e social como processos superpostos na Zona Sul de São Paulo, já que as populações expostas a esses processos têm características em comum de renda, escolaridade, cor, gênero, além de residirem em territórios, nos quais a segregação é marcada por: menor acesso a serviços essenciais, maior exposição a determinados agravos à saúde, efeitos sobre a escolaridade, menores oportunidades de mobilidade social, etc (BORELLI, 2012: 66).

Os distritos da Zona Sul, apesar de similaridades históricas de ocupação, possuem também diferenças de organização social e mobilização política. Interessa-nos as regiões do Campo Limpo, no seu distrito de Capão Redondo, e M'Boi Mirim, em seu distrito Jardim Ângela (especificamente no arranjo de bairros denominado localmente como Fundão do Jardim Ângela, que no nosso entendimento, a partir de pesquisa em campo, caberia uma compreensão ainda para além da região do Jardim Ângela).

Entre as semelhanças, os bairros de periferia da Zona Sul compartilham, em grande parte, sua distribuição, que divide espaço com regiões de grande concentração de riquezas, seguindo às margens dos Rios Pinheiros, Jurubatuba e Guarapiranga, no trajeto, que parte dos limites do município pela Zona Oeste em direção à Represa do Guarapiranga, e segue ao sul em direção aos limites do Município, sendo o maior ponto dessa extremidade em Parelheiros.

A ocupação da região é registrada oficialmente a partir de Santo Amaro, tendo sido uma demarcação distrital distinta de São Paulo, cuja ocupação se consolida enquanto Vila, com seu povoamento por colonos alemães. A região fora considerada um trajeto estratégico de travessia e deslocamento utilizado pelos povos indígenas e possivelmente também por agrupamentos quilombolas entre o litoral e o planalto. Seu povoamento se organizara em 1560 por portugueses. Dada sua característica enquanto 
zona de passagem, logo também serviria enquanto zona de abrigo e refúgio, principalmente por escravizados foragidos (CARRIL, 2006). Passando, com o tempo, de Freguesia, Vila a Município. No final do século XIX, mais populações imigrantes, em sua maioria europeus, passaram a ocupar aquela região, que mudaria seu nome de Colônia Alemã para Colônia Paulista ${ }^{12}$, sendo, posteriormente incorporada ao território da capital do Estado, transformando-se em sub-prefeitura do Município de São Paulo em 1935 (MARTINS, 2003).

Pelo início dos anos 1900, empresas de capital estrangeiro passaram a investir em infraestrutura para a região paulistana, implementando malhas ferroviárias, e a construção das Represas Guarapiranga e Billings. Enquanto a Represa Billings encarregava-se pelo suprimento de energia elétrica; além das funções de controle de vazão hidrográfica e abastecimento de sistema hídrico, a Represa Guarapiranga ficou conhecida como "primeiro passeio paulistano" no início do século $\mathrm{XX}$, tendo ao seu redor construções de sítios e chácaras residenciais ou de recreio, assim como, balneários e clubes recreativos e esportivos náuticos. O sul do Município atravessa então um período de bastante investimento estrutural, surgindo grandes residências próximas às “estradas de rodagem” recém construídas ali. O planejamento da industrialização na Capital do Estado de São Paulo compreendia na região, então conhecida como Santo Amaro, uma "ótima possibilidade de abrigar indústrias e residências operárias, além de bairros de alta classe" (MARTINS, 2003).

A participação da iniciativa privada na expansão urbana ao Sul de São Paulo define um esquema de crescimento em que as demandas precedem de planejamento. Expande-se primeiro para depois se buscarem estratégias de conter os efeitos do

12 "Ao final do século XIX, havia em Santo Amaro, 6249 habitantes. Contavam-se 23 italianos, 11 portugueses, 32 alemães e 15 africanos. Havia (...) 75 filhos de mulheres escravas e 57 escravos (...). Posteriormente chegaram sírios, turcos, espanhóis, russos e japoneses” (CARRIL, 2006: 113). 
desordenamento desenvolvimentista. Empresas e indústrias, especialmente no ramo da infraestrutura, muitas delas de capital estrangeiro, apropriavam-se de loteamentos e, de acordo com sua necessidade de mão de obra, incluíam as "vilas operárias", negociando e comercializando opções de moradias para seus trabalhadores nas regiões onde estes se estabeleciam. Acontece que, conforme foram se dando os processos de expansão urbana e populacional, essas opções já não davam conta do grande número de trabalhadores que deveria fixar-se em São Paulo. Nos anos 1960, houve grande aporte de mão-de-obra oriunda principalmente de Minas Gerais e dos Estados do Nordeste. Já não havia mais como renovar essas estratégias, as empresas e indústrias deixam à mercê do Estado a intervenção diante dessa grande demanda por moradia para a classe trabalhadora. Assim, a Região Sul passa de berço do lazer e do progresso paulistano, tornando-se mais um de seus problemas urbanísticos, num cenário conflitante entre as demandas das classes populares e os interesses por lucro e benefícios do capital, intermediados por ações e políticas pouco efetivas na esfera pública.

A migração mineira e nordestina é um dos eventos mais significativos para a região, havendo ainda nos dias de hoje marcos de sua chegada, por exemplo, em nomes de bairros e vilas, que remetem a esse processo histórico. Neste interim, destacam-se aspectos de transição étnicos e raciais. Uma vez que a região de Santo Amaro, enquanto projeto de estabelecimento de herdeiros de colonos e migrantes europeus, em algum momento atendera a interesses eugenistas, que já não se sustentavam após um período de grande expansão populacional. Produz-se uma periferia negra, migrante, mineira e nordestina, e uma classe média e alta embranquecida nos espaços de maior acesso, mais próximos dos centros empresariais. 
Se adaptando às transições e interesses de mercado, primeiro à agricultura e ao pequeno comércio, depois às grandes corporações industriais, e, recentemente, às tecnologias de informação e comunicação, a região Sul mobiliza grandes injeções de recursos econômicos. O mesmo não se pode dizer do total de sua população de moradores, os quais atravessaram grande desalinhamento entre as movimentações socioeconômicas, na busca por terra, reconhecimento do Estado, acesso a serviços básicos de educação, saúde, trabalho, transporte público, entre outros.

A diversidade da luta pela terra e pela cidadania no Brasil sugere uma reflexão sobre as categorias presentes no quadro de uma exclusão social histórica com implicações etnorraciais. A marginalização urbana não se apresenta somente como recorte de classe social; as próprias formas de acesso à propriedade apontam para uma linha de exclusão racial (BORELLI, 2012: 64).

Entre os anos de 1975 e 1976, são promulgadas as chamadas "Leis dos Mananciais" no Estado de São Paulo ${ }^{13}$, tratam-se das primeiras ferramentas legais no Brasil a tratar do controle sobre os recursos hídricos a partir da ocupação do solo. Visavam, entre outras questões, conter a ocupação do solo à cabeceira das Represas, especialmente a Guarapiranga. Entretanto, a fiscalização sobre o assunto caberia, principalmente, ao Município.

Devido às lacunas do sistema de fiscalização, há um grande aumento da constituição dos loteamentos clandestinos em áreas de preservação. Estes terrenos em específico eram também alvo de especuladores, que os adquiriam para revenda por valores mais acessíveis às classes populares. Formam-se dessa maneira bairros e vilas periféricos conhecidos popularmente como "terra de ninguém" (Laboratório de Habitação e Assentamentos Humanos da FAU/USP, 2003). .

\footnotetext{
${ }^{13}$ Leis Estaduais 898/1975, e 1172/1976
} 
Ao mesmo tempo em que se adensam as ocupações irregulares e as formações de favelas cada vez mais ao Sul e nas extremidades de mananciais; há, por outro lado, a partir da década de 1970 e, principalmente, nos anos 1980, projetos de construção de grandes centros e complexos empresariais naquela região, escritórios e edifícios multinacionais - os "arranha-céus", bancos e prestadores de serviços, hipermercados, hotéis, casas noturnas...

Desde a década de 1980 ocorrem lançamentos de projetos imobiliários, de prédios de apartamentos com quatro dormitórios no Morumbi, no Campo Belo, na Vila Olímpia, no Itaim, em Moema e na Vila Nova Conceição. Novas valorizações e revalorizações de zonas residenciais destinadas às classes médias e alta da cidade, e o consequente processo de verticalização (CARRIL, 2006: 120).

Figura 4: Fluxograma do histórico de ocupação da Zona Sul de São Paulo: do Capão Redondo ao Fundão do Jardim Ângela

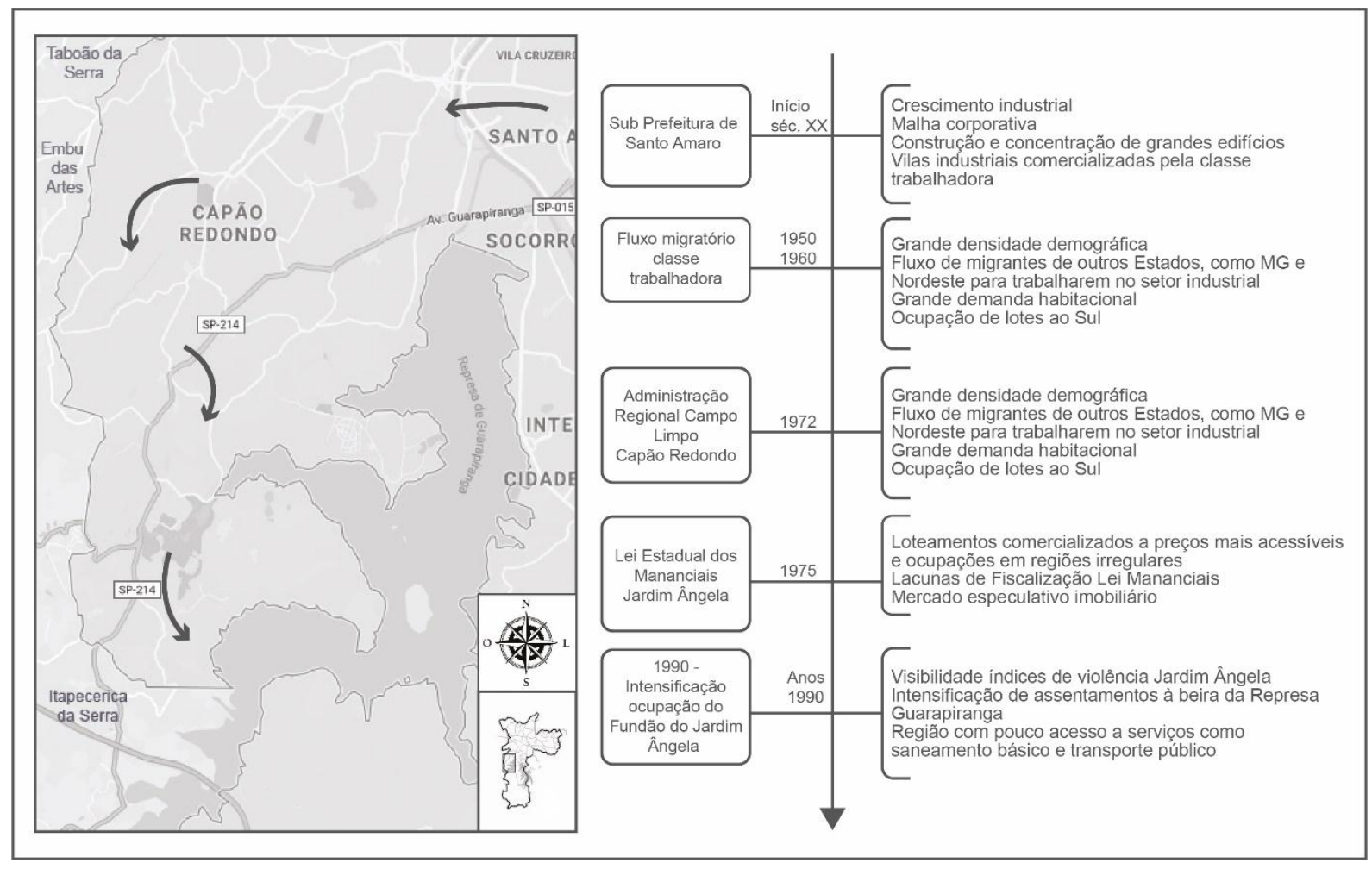

Do autor, 2019. ${ }^{14}$

\footnotetext{
${ }^{14}$ Agradecimentos à Jockastha Guimarães, que contribuiu com o desenvolvimento do presente mapa.
} 
Especialmente após o período de redemocratização brasileiro, constantes negociações entre os "movimentos (sociais) de moradias", implicados pela organização popular de habitantes de regiões ocupadas, regiões de preservação e zonas irregulares em geral, junto a diferentes prefeitos e prefeitas do Município, ocorre um aporte de investimentos do fenômeno que Cavalcanti (2009) denomina pela transição "favelaasfalto".

Palafita, compensado ou MDF, alvenaria, chapisco, sem acabamento. Gradativamente, são estágios de produção de moradia e condições de habitação na favela. "Casa na favela nunca fica pronta", dirá um dos entrevistados de Cavalcanti (2009), a autora, com a ressalva de tratar dos processos urbanísticos do Rio de Janeiro, - portanto, num contexto diferente do estudado aqui, - é pertinente seu posicionamento quando tensiona a noção de "favela consolidada". Por este conceito que serviria para “distinguir, do ponto de vista do planejamento e da governança urbanos, favelas já estabelecidas e bem equipadas em termos de infraestrutura de favelas mais recentes e outros modos de produção de moradia de baixa renda" (p. 70). Para a autora, entretanto, as favelas e regiões periféricas estão constantemente em processos que reconfiguram "relações historicamente constituídas" entre pobreza, ilegalidade e espaço urbano (p. 71). Deste modo, há uma difícil consolidação, uma vez que a favela deve responder a constantes e dinâmicas intervenções, que a posicionam geopoliticamente enquanto região da margem, que a localizam dentro dos trânsitos do capital e de seus comandos acenados ora pelo poder público e pelas políticas públicas, ora pela iniciativa privada, esta última com quem pode comungar muitas vezes e até dividir o espaço, ou, frequentemente, entrar em disputa. 
Diferentes programas habitacionais se estendem às regiões periféricas ao Sul de Santo Amaro, e gradativamente as favelas se tornam, não consolidadas, mas processos de continuidade e descontinuidade urbanística, de natureza transitiva entre regularização / regulamentação e pobreza.

Até os anos 1970, a administração de Santo Amaro e de todas as comunidades ao Sul se organizava enquanto Sub-prefeitura. Em 1972, por meio do Decreto 10.137, é criada a Administração Regional do Campo Limpo (AR CL), reorganizando as estratégias de gestão locais, centradas doravante no Campo Limpo, porém ainda atuando sobre uma imensa área territorial. Em 1990, são propostas as criações de novas subprefeituras, considerando critérios de extensão territorial, renda da população e acesso a serviços e equipamentos públicos. Porém, somente no início dos anos 2000 será criada a Prefeitura Regional de M'Boi Mirim. Discussões e reivindicações sobre reformulações de propostas de gestão considerando os aspectos específicos regionais seguem até o presente.

\section{Capão Redondo: Capão Pecado, Capão Afeto}

"Às vezes eu fico chapado aqui no campão, vendo os pivetes jogar bola, e vira e mexe um corre atrás de um pipa, na real eles tão atrás é de um sonho, tão no fundo de tudo, querendo ter uma vida pelo menos mais digna, com menos baixas e mais amor nesse campo de guerra da nova era" (FERREZ, 2005: 134).

Carril (2006) descreve que Campo Limpo e Capão Redondo faziam parte de bifurcação das grandes estradas de rodagem, como as estradas de Itapecerica e estrada do M’Boi Mirim, que ainda hoje são rotinas de acesso à região. O Capão Redondo se desenvolve a partir de um bairro rural de Santo Amaro, e o sentido de seu nome alude a essa origem: "capão" pode significar uma grande área campestre coberta por mato, ou 
até mesmo uma ave "capada", isto é, castrada para engorda e futuro abate. Essa etimologia é também contestada, sendo ainda atribuída possível semântica indígena no termo. Originalmente, parte da área atual que constitui o bairro eram propriedades, sítios e chácaras de famílias de classe alta que investiam naquela crescente região, propriedades que foram (re)apropriadas, boa parte destas, de maneira irregular, no período de intenso aumento demográfico e migratório, entre os anos 1960 e 1970, destacadamente.

"O lugar mais perigoso do mundo", títulos como esse foram frequentes em matérias de diversas mídias, principalmente ao longo dos anos 1990, disputando anualmente as estatísticas junto ao Jardim Ângela e outros bairros da Região Sul, como Jardim Herculano (bairro pertencente ao distrito do Jardim Ângela) e o Jardim São Luís (na mesma região administrativa do Jardim Ângela, mais próximo a Santo Amaro), ${ }^{15}$ entre outros. A banda Racionais $M C$ 's, originária desta região, narrava em suas canções esse cotidiano de violências, pobreza, racismo, e descaso institucional, que datam também do final dos anos 1980 e início dos $1990^{16}$. Além destes, o Capão é cenário literário para o romance Capão Pecado (Ferrez, 2005). As produções e narrativas em torno da região compõe uma epopeica e violenta distopia, e sugerem uma relação de

\footnotetext{
${ }^{15}$ Cabe dimensionar que os instrumentos de estatísticas, assim como o acesso a equipamentos e serviços públicos próprios de estratégias de gestão geoterritorial vão também "nomeando" as diferentes regiões. Isto é, se em algum momento se tinha somente uma Delegacia no Capão Redondo, as estatísticas criminológicas incidem somente nesta nomenclatura. É particular que as técnicas de georreferenciamento tenham aos poucos se deslocado ao Sul, onde antes era somente "Santo Amaro", depois "Campo Limpo", "Capão Redondo", finalmente, distinguindo "Jardim São Luís" e "Jardim Ângela".

16 "Nesse Capão Redondo, frio sem sentimento / os manos é sofrido e fuma um sem dar guela / É o estilo favela e o respeito por ela (...) O mundo é diferente da ponte pra cá". (Racionais MC's. Da ponte pra cá. Álbum "Nada como um dia após o outro dia" Composição de Mano Brown, 2002). A Ponte João Dias é a paisagem cenário da música, sobrepuja o Rio Pinheiros, estabelecendo os limites da desigualdade social interdistrital, através da Avenida que dá nome à esta ponte, se estabelece um trajeto entre a região corporativa-empresarial de Santo Amaro e Morumbi e os distritos limítrofes, as periferias de Campo Limpo, Capão Redondo e Jardim São Luís.
} 
afetividade de seus moradores com a região, repercutindo em diversas outras manifestações artísticas e culturais, como saraus, bibliotecas e rádios comunitárias.

Velloso (2007) trata de parte desse movimento artístico, político e identitário (os "manos" do Capão Redondo), organizado por escritores e artistas da região, que se uniram pela produção de uma "cultura marginal" ("a marginália paulistana que 'quer tomar de periferia o asfalto' e dizer a que veio") (p.17), assim como em prol das lutas populares de desenvolvimento do Capão Redondo. "No caso da comunidade de Capão Redondo, o hip-hop detonou um processo de ressignificação de valores como a autoestima e o sentimento de capacidade. Os manos, assim, foram se estruturando enquanto comunidade e reorientando modos de agir e pensar sobre a realidade que os cerceia" (p. 40).

O trabalho de coletivos, movimentos e organizações sociais locais é um dos seus atributos de maior reconhecimento popular. "O Capão se organiza" - dirão nossos entrevistados. Especialmente, destaca-se a organização dos movimentos de moradias populares. É importante perceber que devido às mobilizações intensas de órgãos da sociedade civil, o Capão obteve, junto à prefeitura, pacotes estruturais com vistas à urbanização. Além do acesso a asfalto e iluminação pública, e a serviços públicos, diversas gestões implementaram conjuntos habitacionais - as COHAB's, algumas bastante conhecidas na região, como a Cohab Adventista, além de incentivarem construções populares, mutirões onde os moradores se organizaram para a construção coletiva de moradias, havendo algum subsídio do Município para os materiais utilizados, restando a mão-de-obra por conta da organização das comunidades.

[Registro] Outro tema abordado foi a comparação com o distrito do Jardim Ângela, segundo nossa conversa, o Capão tem movimentos politizados mais articulados ligados, principalmente, à demanda por moradia. Conforme um dos profissionais, no Jd. Ângela, 
os movimentos sociais são menos articulados ou mais dispersos e muitas vezes têm ligações partidárias.

A anotação trata da fala de um dos profissionais entrevistados na pesquisa, que demarca sua posição enquanto morador e trabalhador da Zona Sul, e estabelece uma comparação entre as organizações populares de ambas as regiões, Jardim Ângela e Capão Redondo.

[Entrevistado 12] - Hoje moro em Santo Amaro, mas morei bastante tempo na região do Jardim Ângela, que é uma região igualmente parecida com a periferia do Capão, mas me identifico muito mais com a região do Capão Redondo do que onde eu morava.

\section{[Por que? ]}

[Entrevistado 12] - Acho que porque quando cheguei aqui, eu não tinha essa visão de movimento de luta de garantia de direito, hoje eu vejo isso com mais clareza, hoje me sinto mais pertencente à essa quebrada aqui, que é a quebrada [onde] a galera precisa mesmo dessa pegada de garantia de direitos, sabe? [...] Por exemplo, no Jardim Ângela, - eu trabalhava lá como oficineiro, - e lá o pessoal não tem esse movimento de luta como é aqui, é muito raso, muito alienado por parceria de partido. É bem por ai a "parada", é diferente daqui. Porque aqui também tem serviços e pessoas que são alinhadas com parcerias políticas, mas meu norte não é esse tipo de parceria, não é esse tipo de trabalho, aliado com político e muito menos com polícia.

O relato reforça o caráter do Capão Afeto, espaço que mobiliza em seus

habitantes e trabalhadores um sentido transformador, Capão que organiza e sensibiliza.

Capão onde as violências e vulnerabilidades não parecem acontecer sem que aqueles que as acompanhem não se ressintam, e alguns destes anseiem reivindicar um sentido de mudança, Capão que percorre o caminho do pecado de Ferrez à sublimação dos movimentos e organizações sociais. 


\section{Fundão do Jardim Ângela e a vertigem que se tem}

Eu tenho medo de quando a terra se formou. Que tremendo estrondo cósmico.

[...] Lembro-me desse infinito e impessoal passado que é sem inteligência: é orgânico e é o que me inquieta. Eu não comecei comigo ao nascer. Comecei quando dinossauros lentos tinham começado. $\mathrm{Ou}$ melhor: nada se começa. É isso: só quando o homem toma conhecimento através do seu rude olhar é que lhe parece um começo. Ao mesmo tempo - aparento contradição - eu já comecei muitas vezes. [...] Só que eu sou marginalizado apesar de ter mulher e filhos - marginalizado porque escrevo. Pois em vez de seguir pela estrada já aberta enveredei por um atalho. Os atalhos são perigosos. Enquanto Ângela é enquadrada e social.

Ângela tem em si água e deserto, povoamento e ermo, fartura e carência, medo e desafio. Tem em si a eloquência e a absurda mudez, a surpresa e a antiguidade, o requinte e a rudeza. Ela é barroca (LISPECTOR, 1999:32).

Conforme exposto, com a explosão demográfica promovida pela grande onda migratória de trabalhadores de outros Estados e do interior, a busca por moradia impulsionou a dinâmica de ocupação populacional cada vez mais em direção às extremidades ao Sul do Município de São Paulo. Conforme a promulgação da Lei de Mananciais, e ao mesmo tempo em conformidade com incongruências que afrouxavam sua fiscalização, a população passa a se estabelecer às margens das Represas e em outras áreas preservadas, - esse processo se reproduziria em diversas regiões ao Sul, formando comunidades e favelas que dividem o espaço com recursos de água, vegetação e solo preservados, erguendo-se em moradias precárias e de risco, como na região de Parelheiros e Marsilac, nos bairros mais remotos na região do Grajaú, na região chamada Pedreira, e nos bairros que se formaram na região popularmente conhecida por Fundão do Jardim Ângela.

O próprio Jardim Ângela é resultado de um processo de favelização intenso. Região conhecida por suas favelas verticais, cuja visão panorâmica remete a edifícios ou labirintos que emergem tridimensionalmente. Na contramão dos arranha-céus das 
multinacionais de Santo Amaro e do Jardim São Luís, aqui quem se lança ameaçando recobrir os céus são as favelas que se formaram num longo processo cumulativo e sobrepositivo. “Ângela é a minha vertigem.”, disse Lispector (1999) em seu Sopro de Vida, certamente a autora não tratava a respeito do Jardim Ângela, embora essa "vertigem" nos ocorreria, buscando dimensionar, apenas pelo olhar, as diversas vulnerabilidades territoriais do Jardim Ângela, e, sobretudo, do Fundão.

"Triângulo da morte" era a descrição dada para os bairros Jardim Ângela, Capão Redondo e Jardim São Luís, dados seus altos índices de homicídios. Assim como o Capão Redondo, o Jardim Ângela também protagonizou e protagoniza diversas matérias jornalísticas, tendo ganhado grande repercussão a partir de $1996,{ }^{17}$ num documento da Organização das Nações Unidas, que chamava atenção quanto à violência na América Latina (DASSOLER, 2012). A alcunha de "bairro mais perigoso do mundo" é, portanto, um estigma comum às regiões estudadas.

Chama atenção na região sua densidade populacional e seu lento processo de acesso a bens e serviços públicos. Processo que parece ainda estar em curso, especialmente para as zonas de mananciais na região de nosso interesse. Os bairros que compõem o Fundão do Jardim Ângela, carecendo, especialmente, de serviços de transporte público ${ }^{18}$, uma vez que a maioria dos ônibus que circula nesta área sai do Terminal de ônibus do Jardim Ângela, havendo poucas alternativas que acessam outras regiões, como da estação de metrô do Capão Redondo.

\footnotetext{
${ }^{17}$ Buscamos as publicações do Escritório das Nações Unidas sobre Drogas e Crime (UNODC) em seu site oficial, no entanto, a maioria das publicações disponíveis para consulta e download são as realizadas a partir do início dos anos 2000.

18 Em 25 de maio de 2018, tínhamos uma visita agendada com o gestor do serviço de medida socioeducativa na região. No entanto nenhuma das duas linhas de ônibus estava operando na data, devido à uma paralisação. Conseguimos remarcar a reunião com o gestor, porém, para quem não possui carro, neste caso, teria dificuldades para acessar a região, devido à escassez de alternativas de transporte.
} 
O Jardim Vera Cruz foi o ponto focal desta região, onde realizamos a pesquisa de campo. Atendido por duas linhas de ônibus apenas, num trajeto que leva mais de duas horas, em alguns horários, partindo desde o Capão Redondo. Dessa forma, é como se o distrito do Jardim Ângela formasse uma espécie de novo "centro", que abastece a região, e outros bairros e comunidades mais distantes formassem sua periferia. A região do Fundão teria como marco de sua ocupação, a partir dos anos 1990, a (re)apropriação de uma das chácaras desta região, dividia então em 240 lotes (SARDERBERG, 2015), embora a ocupação das áreas seja anterior, provavelmente à época do estabelecimento da Lei Estadual de Mananciais.

O perfil ocupacional deste território foi traçado pela expectativa pela posse de casa própria, apropriada pelos interesses especulativos do mercado imobiliário. Conforme pesquisa da organização social Cidade Escola Aprendiz (2012), 83,8\% dos pais e $78,4 \%$ das mães das crianças matriculadas em escolas locais vieram de outros Estados, o que remete à explosão demográfica dos anos 1950 e à história ocupacional da Região Sul de São Paulo.

Em comparação com o próprio Jardim Ângela, cujos índices de vulnerabilidades ainda guardam elevados parâmetros, o Fundão supera suas estatísticas. Em 2003, na região, havia dados de que o desemprego familiar atingia até $30 \%$ das famílias do Jardim Ângela, enquanto no Fundão esse valor chegava a 50\% das famílias. "Em 2010, dados da Unidade Básica de Saúde da Vila Calu, localizada na região, demostravam que 67,65\% das famílias ainda não possuíam rede de esgoto, 41,34\% faziam uso de fossas, e $25,71 \%$ ainda viviam com o esgoto a céu aberto" (SARDERBERG, 2015). De modo que, pensando técnicas e estratégias georreferenciais de gestão pública, diferenciar essas regiões (entre si, e também diferenciá-las do Jardim Ângela) pode dispor de dados mais 
específicos, bem como de mecanismos para planejamento de intervenções, bem como para monitoramento e avaliação mais fidedignos ${ }^{19}$.

[Entrevistado 1] - No caso do Jardim Ângela, especificamente do Fundão, onde a gente tá, parece que acontece pouco movimento organizado nesse sentido. Você vai em Paraisópolis, você vê ONGs, você vê movimento social, você vê parceria público-privada, sabe? As coisas acontecendo. Até tem de certa forma no Jardim Ângela alguns desses movimentos. Mas aqui (no Fundão) eu vejo muito pouco isso. Muito pouco... Até associações, eventos nesse sentido são bem tímidas.

[No Capão tem mais?]

[Entrevistado 1] - Capão lotado (risos). Até tem no Ângela, mas do Ângela pra lá.

$$
\text { [Mais "centro" de Ângela (risos)] }
$$

Seguindo pela longa Estrada do M'Boi Mirim, ultrapassando o Terminal do Jardim Ângela, ainda perfaz-se grande percurso até a chegada no Parque Guarapiranga, e finalmente, ao subir a Avenida dos Funcionários Públicos, esta que seria a principal via de alguns dos bairros do Fundão; no sentido Represa Guarapiranga, tem-se acesso ao Jardim Vera Cruz e à Vila do Sol, que dá nome ao CEU, e onde se encontram alguns equipamentos públicos de histórico recente, como a AMA; seguindo até os limites do Município, no sentido Itapecerica da Serra, encontramos o Jardim Horizonte Azul.

Esses limites e fronteiras, entretanto, para o observador de primeira viagem podem muitas vezes se confundir, os limites entre assentamentos e ocupações humanas e áreas de preservação natural, notadamente. O Jardim Vera Cruz segue o padrão vertical do Jardim Ângela em alguns trechos, erguendo suas construções de modo cumulativo, numa paisagem vertiginosa. As ruas por nós visitadas contavam com

\footnotetext{
${ }^{19}$ A região do Fundão do Jardim Ângela ainda é incipientemente mencionada em pesquisas, é escopo dos projetos da Organização Social Cidade Escola Aprendiz (CIDADE ESCOLA APRENDIZ, 2012; SINGER, 2015; LABORATÓRIO DE HABITAÇÃO E ASSENTAMENTOS HUMANOS DA

FAU/USP, 2003), além de ser mencionada na Dissertação de Mestrado de Milena Mateuzi Carmo (2017). Há uma tendência em alguns estudos de abordar o Jardim Ângela, tratando também de regiões de assentamentos em áreas de preservação ambiental, não especificando, porém, se são localizados no Fundão do Jardim Ângela.
} 
asfalto, porém as calçadas eram irregulares, seguindo o padrão das construções. Com o tempo, fomos informados que havia regiões com assentamentos e tendências de urbanização ainda mais precários, no Fundão do Jardim Ângela nem todas as residências contam com serviços básicos (CIDADE ESCOLA APRENDIZ, 2012).

Uma das entrevistadas fala a respeito do local de moradia de um dos jovens em cumprimento de medida socioeducativa, morador desta região:

[Entrevistada 14] - Eu já tentei visitá-lo, mas não consigo. Chega num determinado momento, é uma estrada de barro, a gente não sabe onde vai dar. Na beira da Represa.

O jovem é morador do outro lado da Ponte do Jardim Aracati.

"Da ponte pra cá", canção dos Racionais, poderia tratar também do Fundão do Ângela. Ora, se a Ponte João Dias, que inspira a canção, dividia o acesso entre o lado corporativo que ostenta a riqueza da Zona Sul com os bairros pobres e periféricos; a Ponte do Jardim Aracati, no Fundão do Ângela, ligando a Estrada da Baronesa (via que chega a bairros mais "centrais" no Jardim Ângela à Estrada da Cumbica, numa região conhecida por Cidade Ipava), demarca uma divisão entre comunidades vulneráveis e comunidades de vulnerabilidades extremas. A conversa a seguir entre os profissionais exemplifica esta situação a partir deste marco local:

[Entrevistado 1]: - É que assim, a gente tá...

[Entrevistada 13]: - Numa ilha!

[Entrevistado 1]: - Tem represa por todo canto aqui, a gente tá na beira da represa, só que ela faz um contorno, entendeu? Então, por exemplo, tem lugares como o Aracati e Vila Gilda, que são realmente uma ilha. É acessado por uma ponte, inclusive.

[Entrevistada 13]: - Que tá caindo... Mostra os ferros, quando chove, chove mais encima do que embaixo. 
A Ponte do Jardim Aracati foi reformada, porém levou um longo período para que a Prefeitura reabrisse parte de seu trajeto ${ }^{20}$, uma vez que houve mudança de gestão municipal e troca de prefeitos, entre os anos de 2016 e 2017. Neste interim da Administração Pública, na região da ponte, ocorria, frequentemente, grande trânsito de carros e ônibus na região, além de acidentes no trecho, reforçando as dificuldades de mobilidade local. Quando ocorrem intercorrências da ordem de tráfego, como acidentes, ou eventos climáticos, como alagamentos, bloqueando a Ponte, de fato os bairros atendidos por ela perdem a principal via de ligação com os demais bairros até que se restabeleça sua operação.

[Entrevistada 14] - A gente não consegue chegar! Tem lugar que a gente não consegue ir visitar. Você imagina quais as condições desses meninos. Que a maioria deles vive. Então é muito isso. Que condições eu tô dando pra esse jovem pra ele sair dessa zona também de criminalidade, de violência? Que oportunidades o Governo tá dando pra esses jovens, sabe? Então não tem.

Os dois lados da ponte estabelecem fronteiras. De um lado, a Ponte João Dias, cantada pelos Racionais, entre Santo Amaro e Capão Redondo, demarca os limites da expansão urbana em suas contradições. Por outro lado, a Ponte do Jardim Aracati ao Fundão do Jardim Ângela faz uma ligação entre as favelas mais ou menos "acessíveis", aprofundando relações de desigualdades mesmo em regiões onde já são identificadas vulnerabilidades sociais e ambientais - as chamadas hiperperiferias, - processo constitutivo de favelas que são "mais" favelas, zonas excluídas até mesmo das medidas de inclusão, tangentes que seguem persistindo em relação aos "novos centros" nas periferias. O Estado se insere com relação a suas margens (Das e Poole, 2008) numa dimensão, não somente de centro-periferia, como de "espaço entre os corpos, a lei e a

\footnotetext{
${ }^{20}$ A reforma previa duplicar a capacidade da Ponte, uma vez que os veículos, em algumas partes do percurso, paravam para aguardar a circulação dos veículos no sentido contrário. A demora para inauguração da mão dupla se devia à necessidade de conclusão da sinalização, a duplicação foi entregue e inaugurada em 31 de maio de 2017.
} 
disciplina", estabelecendo limites de onde começa e acaba o Estado, pelos critérios do que prioriza em sua distribuição de incentivos. Ou, ao contrário, pelo que negligencia, relegando conflitos de "legitimidade e ilegitimidade" a permanecerem em suspenso. São regiões de fronteiras (OLIVAR, 2015), isto é, dispõem de politicas de fronteira apresentadas na "tensa relação local com as formas institucionalizadas de poder", "o desejo governamental, a experiência da violência e a desconfiança moral” (p. 177), regiões situadas pelo pânico moral das terras de ninguém, dos lugares mais perigosos do mundo, que tipificam comunidades e moradores para além desses trajetos. Havendo, portanto, violações de direitos que são, não somente de indivíduos, como coletivas e regionais.

Diante de cenários como este, que dispõem, no campo das políticas públicas, de repertório limitado de soluções simples ou imediatas, em dado momento durante a realização da pesquisa empírica, nos vimos diante de uma constatação e uma pergunta, as quais cabe sua exposição pela transcrição do registro a seguir.

[Registro] Eu sou um ignorante completo da realidade de São Paulo. É com esta constatação que inicio meu registro, lembro da sensação de "abismado" após a primeira visita ao Jd. Vera Cruz, e acho que ela continua, e continuará em todas minhas visitas em campo. Mas hoje descobri que o MSE Jd. Ângela atende toda uma região conhecida por Fundão do Ângela, formada por bairros adjacentes à represa que constituem uma espécie de "ilha".

Previamente à primeira visita realizada ao território, ocorrida ao final de março de 2018, dispúnhamos de dados e informações acerca do Jardim Ângela, sobre seus elevados índices de violência, sobre as vulnerabilidades juvenil e territorial ali encontradas. No entanto, não tínhamos conhecimento sobre o "Fundão do Jardim Ângela" ou sobre seu histórico de ocupação. Não compreendíamos que o processo de favelização da região advinha de um movimento urbanístico que empurrava cada vez mais pretos e pobres ao Sul, como se tentasse expulsá-los do território, impedi-los de 
acessar direitos básicos, numa relação perversa da especulação capitalista, em conivência com o Estado. O Fundão do Jardim Ângela não é visível pela ferramenta online de rotas, Google Maps, em sua função de visualização de ruas, e, ainda que o fosse, o pesquisador não saberia de seus desníveis, das casas que se abarrancam, algumas vezes beirando as estradas de rodagem, outras vezes, para dentro da Represa, sob risco de deslizamento. Não se recordaria do padrão vertical das favelas do Jardim Ângela, da paisagem que provoca vertigens "clariceanas". Chegando ao Fundão do Jardim Ângela, no Jardim Vera Cruz, seria alertado que ali ainda não era a extremidade - a fronteira da vulnerabilidade dessa região, que ainda há mais bairros, comunidades, aglomerados, de casas e de pessoas que vivem à guisa. Talvez ouvíssemos a respeito da escassez da malha de transporte ou do acesso dificultoso e longínquo, sem vivenciá-lo ${ }^{21}$. A práxis em campo, a amostra de realidade empírica, neste caso, guiaria os dados, as informações e a teoria, direcionando o sentido.

Na última visita de campo ao Jardim Ângela, no mês de junho de 2018, a sensação de "abismado" ainda persistia. Era um início de tarde comum, enquanto aguardávamos no ponto de ônibus junto a adolescentes saídos da escola, idosos e adultos, tivemos mais algumas constatações ante a despedida do campo. Que descrever os cenários e a vida nas favelas deve ser feito a partir de um compromisso social $^{22}$, despojado do "romantismo" que algumas vezes pode percorrer a descrição de pesquisadores e teóricos numa inspiração literária. E que, mesmo sem "romancear", as pessoas ali estão vivendo suas vidas, buscando no que está em seu alcance e

\footnotetext{
${ }^{21}$ Alguns agendamentos em campo, junto à OSC3, tiveram de ser desmarcados devido à uma paralisação ocorrida em maio de 2018, que afetou o abastecimento e reduziu a circulação de ônibus no Município.

${ }^{22}$ Monceau (2005) defende o "comprometimento do pesquisador" (p. 472). Menezes et. al. (2018) falam sobre o compromisso social e implicação pessoal com a justiça ético-política-científica no fazer da pesquisa. Bader-Sawaia (2008) também trata do comprometimento com os sujeitos e com as esferas sociais, subjetivas e políticas da vida na pesquisa.
} 
possibilidades. "Mas como pode alguém viver correndo tantos riscos"? - Foi a pergunta que deixamos em nossos registros de campo, enquanto admirávamos a hipnótica vista das favelas, paisagem que inspira noções de risco de desabamentos, riscos ambientais, riscos pela violência, riscos...

"Viver em áreas de risco" é o título do trabalho de Spink (2014), no qual aborda o cotidiano das populações residentes em áreas de mananciais no distrito do Jardim Ângela. A autora aponta a importância de definição da noção de risco (Spink, 2001), a partir de um levantamento dos usos desse conceito: num primeiro momento "risco emerge como conceito quando se torna possível pensar o futuro como passível de controle", em seguida, se desenvolve como "mecanismos de controle distintos" por meio da "gestão dos riscos". No terceiro, um processo de transição para uma "sociedade de risco", na qual serão produzidos mecanismos de exclusão social a partir de tecnologias de vigilância, em que a "norma cede lugar à probabilidade" do risco. Este parece-nos se aproximar mais da relação entre o Fundão do Jardim Ângela e os mecanismos e perspectivas de gestão territorial pelos quais o bairro é comumente compreendido / compreensível. Posteriormente, teorias mais recentes que operam num cenário dos "jogos", a "partir da contraposição de explicações alternativas", como risco e aventura (p. 1287).

Spink (2014) também constata que há pouca interlocução das ciências humanas sobre questões ambientais, tal conclusão se daria por um "estranhamento", "tendo em vista que [...] correntes mais atuais de análise de desastres incorporaram noções como vulnerabilidade e resiliência, que necessariamente impõem um olhar sobre as dimensões históricas, sociais e culturais que se fazem presentes na vivência cotidiana de riscos ambientais" (SPINK, 2014: 3753). Cabe, para compreender tais questões, - 
conforme indica a autora -, a mobilização de uma rede heterogênea de atores e de autores. 


\section{Capítulo 5. TRABALHO, SOCIEDADE, ESTADO E VIDA NUA}

Neste tópico, estabelecido a partir dos relatos dos profissionais e dos registros feitos na pesquisa de campo, tratamos dos atravessamentos de mercado sobre os territórios, em termos de acesso e agravamento de exclusões, como trabalho e renda. Tratamos ainda da ação regulatória feita pelo Estado, impondo sua legitimidade em medidas de intervenção controladora e punitiva. Também falamos sobre as possibilidades que se aventam na esfera social da concorrência de discursos de proteção social de direitos de adolescentes e jovens junto a discursos que reclamam por mecanismos repressivos mais severos, concebendo legítimas as ações de violência e controle por determinados agentes do Estado, no que tange a sujeitos "matáveis" ou “execráveis" da esfera política, discutidos, a partir do conceito de vida nua, do pensador Agambem (2007).

\section{[Registro sobre] as drogas na periferia}

[Registro] Acabei me intrometendo na conversa e Dona Aiocá me mostrou os medicamentos que seu filho fazia uso. Sete comprimidos ao dia, a mesma disse que a dosagem já foi até maior, esse número e está sendo reduzido. Depois explicou que ele havia sido internado devido a seu uso de drogas recentemente. O jovem apresentava sintomas psicóticos, segundo o relato de Dona Aiocá, ouvia vozes e em alguns momentos sua interação interpessoal era afetada por esses sintomas. Desde muito tempo, tem uma "implicância" com o irmão menor, afirmando que o mesmo o "persegue". Afirma ver e conversar com divindades, como Jah e Exu. Seu uso de drogas iniciou aos 16 anos, após seu primeiro emprego. Ganhava o mesmo que sua mãe e juntos sustentavam a casa, mas logo estava gastando no consumo de drogas. Começou com maconha, o que, pelo relato da mãe, supõe-se ter contribuído no desencadear dos sintomas psicóticos. Logo, estava usando diversas outras substâncias, cocaína, ecstasy, e lança-perfume. "Graças a Deus, ele se livrou do lança", disse a mãe. E me lembrei de algumas conversas informais 
sobre a região do Campo Limpo e Capão Redondo, e a informação que o lança-perfume é uma das drogas mais usadas e que mais têm afetado a juventude ali $^{23}$. Duas das técnicas, moradoras da região, e a cozinheira, que trabalha no MSE, me contam que lá "é muito fácil conseguir drogas". A cozinheira conta que, no quintal de sua casa, caem muitos pinos de cocaína deixados. Em tom jocoso, conta que brincou com seu marido que quem chega lá pode até confundir e achar que são usuários.

Dona Aiocá segue o relato dizendo que logo seu filho entrou para o tráfico e foi detido. Como não a estava entrevistando formalmente, não perguntei se havia sido detido ou internado na Fundação Casa.

Seu filho tinha uma significativa relação com o trabalho, segundo a mãe, "para sustentar seu vício". Prometera que iria trabalhar novamente e "parar com essas coisas", mas logo estava novamente envolvido ${ }^{24}$. Logo mais, estava no tráfico para "pagar suas drogas". Enfim, fora detido... O sentido de trabalho, no discurso desta mãe, era ampliado, de modo que não fazia acepção que excluísse o tráfico.

Agora estava em tratamento psiquiátrico nos CAPS da região, mas em um deles, o CAPS AD, conheceu um amigo, que o está levando novamente a buscar drogas. Tem até vendido balas no farol, para pagar por suas drogas. A técnica me chamou para subir novamente e aguardar os demais técnicos que ainda não haviam assinado o TCLE. Acho que na intenção de evitar maior contato com Dona Aiocá. Subindo as escadas, falei pra ela que "lança" era muito comum na região (conforme informação que tinha informalmente). A mesma respondeu que sim, mas que o lança usado ali não era o mesmo que os "boys" usam, era misturado com querosene, um monte de coisa, portanto, mais prejudicial em seus efeitos ao organismo.

As drogas, ora como mercadoria ora como objeto de desejo ou necessidade, outrora como ferramenta de socialização (a figura do amigo) e de trabalho (vender para comprar), aparecem nos discursos como uma presença constante do cotidiano (no quintal de casa), não só para os jovens em atendimento socioeducativo, mas para os demais moradores de periferia. Em alguns momentos, droga e alegria, em outros, drogas e morte se associam nas narrativas periféricas, conforme o registro. Droga e trabalho, produtividade. Droga e loucura, "vício". Drogas lícitas (sete comprimidos ao

\footnotetext{
${ }^{23}$ Não tivemos acesso a dados epidemiológicos sobre drogas específicos da região, no entanto, Santos (2016), em sua pesquisa, cuja temática é a participação social na saúde na região Sul (os encontros se davam no Jardim Ângela), também se depara com relatos de mortes de jovens por uso de lança perfume.

${ }^{24}$ Categoria êmica, que será discutida em tópicos posteriores.
} 
dia) para continência das ilícitas. Para Dona Aiocá e seu filho existem esses paradoxos entre vida e morte, produtividade e loucura, que parecem se estender, não só, como o paradoxo das drogas, como, nessa conversa, a um itinerário de vida (e morte) na periferia.

Scisleski (2010) apresenta em sua pesquisa as diversas, simultâneas e ambíguas possibilidades de inserção e exclusão social, produzidas pelas drogas, especificamente, para a juventude em conflito com a lei.

$\mathrm{O}$ que vemos até aqui? $\mathrm{O}$ envolvimento de adolescentes em conflito com a lei com o tráfico de drogas [...], mas também vemos que a droga tem uma função socializadora, não apenas por lhes permitir acesso a bens de consumo e a uma inserção no mercado (ilegal) de trabalho (SCISLESKI, 2010: 72).

Tendo em vista a complexidade da discussão e o limite que tivemos pela obtenção dos dados, optamos por segui-la a partir do que mais nos chamou atenção neste e em outros registros, a partir das drogas: as dimensões do trabalho.

\section{Os meninos que assobiam: dimensões do trabalho no território}

[Entrevistada 14] - E a gente aqui no serviço, a gente vê isso o tempo todo. A gente vê adolescente que ele não quer mais o mundo do crime, ele não quer mais traficar; mas, ao mesmo tempo, ele vai, tenta se encaixar no sistema formal de trabalho, não tem vaga. Aí ele fica sem ter perspectiva. E ainda muito pouco o trabalho, as oportunidades que dão pra esse jovem de engajamento, primeiro emprego, sabe? São escassas.

[Entrevistada 6] - E mesmo quando ele consegue, são coisas em áreas centrais. E, pelo menos eu, tem visitas que eu vou fazer, lugares, eu penso "como que eu saio daqui todos os dias pra fazer alguma coisa"? Tem lugares mais ou menos, mas tem alguns específicos que me causa desespero pensar de sair de lá todo dia num determinado horário.

A disposição territorial das ofertas de inclusão profissional parece um desafio para o cotidiano em regiões periféricas. Quando analisado, o marcador geracional tende a aprofundar os aspectos dessa questão. A Organização Internacional do Trabalho 
(OIT), no ano de 2012, aprovou o documento "A crise do emprego jovem", no qual aponta que "o desemprego e o subemprego jovem persistentes trazem consigo elevados custos económicos e sociais e ameaçam o tecido social das nossas sociedades”.

"Tecido social” que passa pela garantia de direitos cosida na contratualização entre a sociedade e o Estado no sistema que investirá de direitos adolescentes e jovens. Não havendo opções de sustento e renda aos jovens e suas famílias, as demais estratégias passam a ser aceitáveis, para além do terreno do que é formal ou lícito, de modo a contornar as possibilidades e necessidades dispostas pelo mercado.

Lyra (2013) discorre sobre as "estratégias de adesão" do jovem implicado em situação infracional, a partir de sua pesquisa feita no Rio de Janeiro. Para o autor, o tráfico de drogas e o roubo despontam como atividade de sustento, os jovens então são compreendidos e entendem a si mesmos como trabalhadores num "mercado informal ilegal" (p.73). Malvasi (2012) identifica o caráter das relações trabalhistas que o tráfico mobiliza, pontuando os atravessamentos macro e microeconômicos e seus impactos nos territórios periféricos e na "socialização" jovem: "Os jovens moradores das quebradas se socializam em contato com o comércio de drogas realizado por vizinhos, amigos e parentes. O tráfico de drogas, parte da economia global, chega aos territórios como um importante componente da economia local" (p. 79).

Em pesquisa apresentada pelo Centro Brasileiro de Análise e Planejamento CEBRAP (2018), o tráfico de drogas, no que tange ao recrutamento e à atuação de adolescentes e jovens, é apresentado em suas ambiguidades, uma vez que é oficialmente reconhecido enquanto modalidade do trabalho infantil pelo poder público, como evidenciado por meio do Decreto $n^{\circ} 6.481 / 2008$ da Presidência da República, que ressalta que: "a utilização, recrutamento e oferta de adolescente para outras atividades 
ilícitas, particularmente para a produção e tráfico de drogas" consta entre as piores formas de trabalho infantil (BRASIL, 2008; Galdeano e Almeida, 2018). Entretanto, conforme identificam Galdeano e Almeida (2018), do CEBRAP, há uma ambivalência que prospera na condução jurídica dos casos de adolescentes implicados ou acusados de infrações relativas ao tráfico de drogas. Nesse sentido, o sistema de medidas socioeducativas encaminha o jovem a um sistema infracional, que se direciona à correção do "desvio", não reconhecendo a situação de trabalho infantil e violação de direitos a que o jovem está subordinado.

No atendimento socioeducativo em meio aberto, os profissionais têm de lidar com essas contradições, coordenadas por outras pontas da gestão institucional dos jovens em cumprimento de medidas, como o Poder Judiciário.

[Entrevistado 12] - Muitas vezes, eles [os juízes] impõem essas condicionantes pra encerrar a medida [em meio aberto], coisas que tá meio que, não tá previsto ali. Por exemplo: [o juiz fala] [...]"Só vou encerrar a medida se ele tiver trabalhando". Mas com 15 anos [de idade]?! Não faz sentido! Mais um pouco, o Poder Judiciário tá reforçando o trabalho infantil. Então é muito louco isso.

Telles (2010) dirá que para além da constatação da "exclusão social”, a compreensão dos percursos de desemprego ou trabalhos precários exige uma leitura atenta de "como esses dramas se configuram em mundos sociais e tramas de relações que escapam dos dados e indicadores que medem as transformações recentes no mercado de trabalho" (p. 93). Em campo, é possível observar algumas das esferas dinâmicas que abrangem o tema do trabalho, e como estas se dimensionam no território, embora ocorram também em quase todas as regiões da cidade. São elas, (i) a mendicância e o expediente religioso, (ii) o comércio formal e (iii) informal, (iv) o tráfico de diversas naturezas, sendo o de substâncias o mais relevante, e sua relação com a ação fiscalizadora policial. 
A mendicância é uma das estratégias territoriais de sustento ou complemento econômico, é observada, principalmente, nos meios de transporte público, como ônibus, trens e metrôs. Na região Sul do Município, observamos em todas as ocasiões de ida ao campo a ocorrência da mendicância ou de uma modalidade similar, as "orações" nos transportes coletivos, são os expedientes religiosos, que ora diferem, outrora se confundem com o expediente da mendicância.

O trabalho formal, principalmente o comércio, atinge grande faixa das regiões periféricas estudadas, movimentando pequenos centros econômicos de circulação de mercadorias. A informalidade atravessa ainda as redes formais, por exemplo, pela venda de produtos como filmes e jogos "pirateados" (outra forma de tráfico), em lojas, pequenos mercados e hortifrútis. Há, conforme descreve Feltran (2008a e 2008b), em muitos contextos, a sobreposição dos mercados ilegais, que disputam legitimidade social.

A rede informal ${ }^{25}$ tem um caráter de organização, concorre com a rede de mendicância e orações pelos espaços nos meios de transportes coletivos. Chama atenção pelas formas de comunicação não-verbal estabelecidas entre os comerciantes de trens, ônibus e metrôs, assobiam uns aos outros, se denunciam por olhares e às vezes gritos e vocalizações, indicando o momento ideal para a entrada e retirada do vagão ou a presença de agentes de segurança das concessionárias de transporte, que combatem ${ }^{26}$ a

\footnotetext{
${ }^{25}$ Talvez a definição estrito senso de "tráfico", como comércio ou mercado ilícito, poderia absorver a noção de "trabalho informal" aqui apresentada. Entendemos sua diferenciação, pois, a partir dos relatos, surge o "tráfico de cargas" e o "tráfico de substâncias", como diferentes formas de organizações. Haveria uma noção popular que distingue aquilo que é mais ou menos lícito de acordo com sua aceitabilidade social. Sobre o tema da disputa por legitimidades sociais trata Feltran (2008 a e 2008b).

${ }^{26}$ Entendemos pelas nossas observações que a repressão ao comércio informal pode variar por critérios pouco objetivos, dependendo da concessionária do transporte público e até mesmo da gestão estadual. Embora este não seja o tema para esta pesquisa, temos a hipótese que a gestão estadual e suas políticas, quando de um partido mais conservador, tende a aumentar a proibição do comércio nos meios de transporte públicos. Ainda que a administração dos transportes por empresas estatais, como o Metrô e a CPTM, tende a ser menos repressiva às práticas que a concessão por companhias privatizadas, como a
} 
prática comercial. Em uma das voltas do campo, na Linha 9-Esmeralda da CPTM (Companhia Paulista de Trens Metropolitanos), presenciamos um grupo de jovens que entram falando em tom ameaçador na estação, o que gera certa comoção entre os passageiros, estes logo compreenderão que a razão para o nervosismo ${ }^{27}$ do jovem era a prática de inibição usada por seguranças e funcionários da CPTM. O grupo unido prometia vingança, desceu algumas estações depois e não foi possível saber o que ocorrera em seguida...

[Registro] Vários jovens que trabalham no comércio informal dentro dos trens estavam agitados dizendo que iam se reunir pra pegar um "ganso" (termo que depois descobriria um significado que passa entre "delator" e "intrometido"). Desceram algumas estações à frente e se dirigiram a um segurança da CPTM com gritos, e tentando cercálo. O trem ficou parado um pouco, com os passageiros alarmados, depois seguiu viagem sem que soubéssemos o que aconteceu. Provavelmente nada. Mas a aparente pouca idade daqueles jovens comerciantes me fez pensar que poderiam ter alguma relação com os jovens que figuram os discursos de minha pesquisa. Buscando se adaptar à competitividade do mercado de trabalho, e inseridos na informalidade das dinâmicas do capital, muitas vezes em uma atuação em grupo, associada a amigos, parentes e conhecidos, e com diversas razões e desejos para bancar seus sustentos, seja o consumo de drogas, seja os relacionamentos, o status, ou o provento e a subsistência. Esses também são os diversos "motivos" da chamada "adesão", termo utilizado por Lyra (2013).

A primeira visita ao Fundão do Jardim Ângela, enquanto buscávamos o endereço informado pelos interlocutores, passávamos por uma das principais vias do território, onde havia jovens em posições estratégicas, agrupados em frente a alguns pontos comerciais e em esquinas. Começaram os assobios. A princípio, esta movimentação nos produz certa apreensão. Até percebermos a similaridade desse meio de comunicação (e da comoção pelo "nervoso") com o que ocorre no comércio dos trens da CPTM.

Via4 e Via Mobilidade, que passaria a administrar a linha 5 (lilás), atendendo a região do Capão Redondo.

${ }^{27}$ O nervoso na vida na cidade é uma categoria trabalhada por autores das ciências sociais, como Duarte (1986) e Pelúcio (2009), que entendem o "nervoso" como noção que intermedia os valores orgânicos e morais, compreendida em conformidade a critérios sociais. 
Constataríamos, elaborando os discursos dos profissionais do sistema de medidas socioeducativas, o papel econômico do tráfico e sua relevância para o sustento familiar. Naquela região, despontam outras variadas opções de trabalho informal e desprotegido, até mesmo profissões que não concentram mais muitos trabalhadores, como as "lavadeiras", ainda engajam aquelas que vivem próximas às margens da represa.

Mas afinal o Estado determina suas margens ou as margens determinam o Estado? Essa questão, que remete às teorias de Das e Poole (2004 e 2008) se interpõe à compreensão das dinâmicas territoriais periféricas. Quem estabelece onde está o centro, num cenário com inúmeras tangentes? Com a noção de hiperperiferia, Carril (2006) nos aponta uma assimetria na distribuição desenvolvimentista, cabe, contudo, destacar que as dinâmicas locais são constantes e indicam estratégias que são contínuas na busca por inclusões nos espaços de segregação e exclusão, que poderão ou não engendrar novas centralidades nos territórios periféricos, pela formação comercial de ruas ou calçadas ou vielas, nos meios de transporte coletivos, nas beiras de represa no trabalho de lavanderia, ou ainda nas "biqueiras", como são conhecidos os pontos de vendas de drogas, espaços permanentes ou móveis por onde se desloca o capital formal ou informalmente.

Desse modo, essa perspectiva abre uma interessante possibilidade de análise do Estado, não porque registre ou capte formas "exóticas" presentes nas margens, mas porque insinua que as margens são implicações necessárias do Estado e, portanto, não podem ser lidas no registro de conceitos que apresentam as margens como anômicas, caóticas ou desordenadas, e sim como móveis e dinâmicas. O que é aplicável às margens pode generalizar-se e normalizar-se para todas as populações, do mesmo modo que a regra é parte constitutiva da exceção (MIAGUSKO, 2016).

O trabalho de Miagusko (2016) retoma o conceito de "margens", estabelecido por Das e Poole (2004; 2008): a partir das descrições de territórios periféricos enquanto 
lugares violentos e precários, o Estado legitima estratégias de regulamentação e retomada desses territórios. Cabendo analisar o Estado a partir de suas práticas pelas margens. Reconhece-se, então, o importante papel das margens na constituição do Estado. Retomamos a leitura de Das e Poole (2004 e 2008) no entendimento das funções ordenadoras do Estado por meio da violência sobre suas margens, e também na definição do conceito de margens enquanto "periferia", como "legitimidade e ilegitimidade" e como "espaço entre os corpos, a lei e a disciplina".

Pode-se pensar ainda que há fronteiras, interpostas por questões menos concretas que abstratas, que regulamentam esses câmbios de mercado trabalhista na região, porém, mais visível e notadamente, há também agentes em função do Estado que serão permissivos, reguladores ou coercivos, na disposição dessas dinâmicas econômicas locais, cumprindo o papel fiscalizador e mantenedor de tais fronteiras. A ação policial emerge fazendo um contraponto, e também participa desses fluxos de capital pela via da regulação. Desempenha papel de grande importância para a compreensão de muitas das organizações locais, pensando naquilo que ofertarão para resistência ou assimilação.

Para Miagusko (2016) o “microcosmo do tráfico", para além de mobilizar os mercados ilegais, trata de "mercados políticos" (Miagusko, 2016; Misse, 2011); dizendo respeito a códigos que, ainda que não estejam decretados em lei, se apresentam em conjuntos informais de regras, as quais, pelo descumprimento ou incompreensão, podem levar a “decisões de vida ou morte" (p. 07).

As trocas nesse mercado informal combinam dimensões econômicas e políticas, no sentido de maior controle ou flexibilidade do Estado na repressão da distribuição e na própria ação dos agentes encarregados em reprimir a circulação dessa mercadoria. (MIAGUSKO, 2016: 06). 


\section{[Relatos sobre] a ação policial na periferia}

Em posterior visita ao Fundão do Jardim Ângela, perceberíamos uma nova dinâmica já na chegada ao bairro. Ao descer do ônibus, nos deparamos com um bairro mais silencioso, menor circulação de pessoas pelas ruas, praticamente apenas os comerciantes locais funcionavam normalmente.

[Registro] A princípio, entendi que era por ser de manhã, por volta das $10 \mathrm{~h}$. Porém, ao chegar no MSE, e ser recebido pelo técnico, o mesmo explicou que, àquele dia, haviam muitas viaturas circulando o bairro. Este mesmo técnico e o gerente fariam uma visita domiciliar agendada, porém, precisaram cancelar, pois, ao saírem, viram a movimentação do bairro. Seis viaturas "Blazer" (modelo do carro), com policiais armados, faziam ronda ostensiva na região. Na noite anterior, acontecera uma tentativa de roubo de carga na região, aparentemente frustrada. Numa troca de tiros, um segurança do local foi morto, e segundo os boatos, tratava-se de PM (policial militar), que trabalhava num "bico" de segurança ${ }^{28}$. Também, segundo os boatos que circulam, entre os envolvidos no roubo, havia adolescente(s)... Os técnicos precisaram alterar sua programação no MSE. E ao longo daquele dia, enquanto os entrevistava, pude assistir como este acontecimento reverberou em sua dinâmica. Os telefones tocavam sem parar. Um dos jovens, que chegou pouco antes de minha saída, ligou pra avisar que sofreu um "enquadro", e lhe foi recomendado ir ao MSE para atendimento / acolhimento. O professor (da oficina) de grafitte chegou no período da tarde, mas a aula, provavelmente, seria cancelada, devido à movimentação no bairro. No dia seguinte, sábado, haveria uma prática de grupo, para discutir o tema "Saúde Mental", porém também seria remarcada, como soube posteriormente.

Dessa forma, todo o planejamento do serviço de medida socioeducativa em meio aberto sofre alterações, dados os acontecimentos regionais, e a movimentação policial característica de situações excepcionais. As chamadas rondas ostensivas, prática que consiste na circulação de agentes policiais pelos territórios exibindo armamento, um “apelo às armas" utilizando veículos terrestres e, em algumas situações, sobrevoando em helicópteros. Presume-se que não somente este serviço seja afetado em

\footnotetext{
${ }^{28}$ Zaluar (2014) relaciona a emergência da segurança privatizada à insuficiência do Estado em dar conta da questão da segurança pública.
} 
circunstâncias como essa, mas que reverbere tal excepcionalidade afetando as atividades de todo o cotidiano do bairro e arredores.

Ainda seguindo Miagusko (2016), este autor dirá que “diferentes regimes territoriais também influenciam a dinâmica desses mercados", sendo comum nas áreas pobres da cidade, junto a reivindicações constantes pela presença do Estado - por meio da promoção de políticas de inclusão -, haver também a mobilização de iniciativas individuais e coletivas de resolução dos problemas, de modo a buscar prescindir do Estado. "Esse mesmo Estado, no entanto, está lá presente no modo como estruturou uma espécie de mercado político" (p. 10). A presumidamente frustrada tentativa de roubo de carga, ocorrida na noite anterior, parece representar essa dinâmica de busca por acesso a "mercadorias" ilícitas e políticas. Os agentes do Estado, aqui são representados pela polícia militar: se apresentam, nas narrativas, em função, como nas rondas, no dia, ou ainda desvestido (à paisana), na noite, atuando em posições de complemento de renda, no mercado da segurança privatizada. A quebra dos códigos: o ataque à carga pelo ou pelos adolescentes (a informação era incerta) que figuravam a tentativa de roubo, e a revanche policial contra toda a região, reiterando a complexidade de um sistema de normas e punição que vigora extraoficialmente.

A ação policial se destaca na fala dos entrevistados, principalmente, como uma agência que transita e se desloca no território e com intenção e poder desmobilizador e, por vezes, contraposto ao trabalho socioeducativo.

[Entrevistado 8] Recentemente, teve um serviço de medida que os policiais invadiram o serviço.

A entrada da ação policial no serviço de medidas socioeducativas em meio aberto promove um contrassenso a seu projeto, pensado para promover o direito à convivência no território e garantindo a liberdade, ainda que restrita. Essas ações são 
entendidas pelos profissionais como possibilidade de ruptura dos vínculos desenvolvidos junto aos jovens e, possivelmente, evasão ou baixa efetividade das ações.

[Entrevistado 8] - E essa é uma das crises que a gente passa, a gente quer um espaço de convivência, mas já teve um dia do menino sair, chegar, e depois ir um policial lá. Falando que ele tinha feito um ato [de infração à lei] e tava fugindo. [...] A gente conseguiu articular, e depois resolveu a situação. Teve um dia que um policial tava procurando, bateu lá e falou, "tal pessoa tá aqui"? - O serviço não é identificado [com placas] e tal. Ele falou, "porque eu tava na casa dele, a mãe dele falou que ele tava no L.A.”. Só que mãe, a gente ligou pra mãe, a mãe falou que nem falou onde era. E o policial sabia onde era o serviço. Então a gente tem muito medo.

Os profissionais parecem comentar entre si com certa frequência sobre as ações policiais, dada à dimensão destas nos territórios periféricos, e suas influências no desenvolvimento do serviço. Nas entrevistas, porém, tratam com cautela o assunto.

[Entrevistado 8] - Tem uma perspectiva do Estado que tá tudo bem, a polícia não mata e tal. E a gente vem discutindo, "mano, não, a gente tá na ponta, a gente sabe que isso não é realidade". Como a gente vai lidar com isso?

Cautela que os discursos de outros agentes do Estado parece produzir, de modo que se evite falar a respeito do tema. "Estar na ponta" é atuar nos processos de execução, nos serviços de atendimento direto à população, denota oposição a quem está "na gestão", isto é, nas posições da administração, monitoramento e planejamento das politicas, ou em posições técnicas intermediadas pela "ponta", como no Poder Judiciário. O profissional fala de uma possível incompreensão, descrença ou silenciamento imposto pelos profissionais de outras esferas.

Os entrevistados falam de um Estado que se apresenta em capilaridades, nas diversidades, que encena diferentes faces e naturezas distintas orientando a condução de casos semelhantes. Tal qual proposto por Foucault (2010), esses arranjos do poder nada mais são que feixes de relações (p. 248).

Já perto da conclusão da entrevista, um dos entrevistados menciona: 
[Entrevistado 12] - E ali é aquela coisa, o cara é mais considerado por matar mais gente. No meio deles lá, quanto mais se mata, e da maneira que se mata, é mais considerado, é mais respeitado. É produção.

[Produção de morte]...

Produção de morte, tema que trataremos a seguir.

\section{[Relatos sobre] a morte na periferia}

[Entrevistado 1] - Eu não moro mais, hoje, em área periférica, mas a morte na periferia ela tá muito mais evidente. Você tem acesso à morte muito mais que em outros locais, que você assiste pela TV.

[E na TV também a gente só assiste morte].

- Então, mas ainda na TV, não é algo palpável. Por exemplo, se eu tô assistindo na TV, eu vou criar uma raiva encima do acontecimento, mas eu não tenho acesso à pessoa. Na periferia, esse acesso tá muito evidente. Tanto que o SINASE mesmo fala de um índice, acho que é $18 \%$ de morte de adolescente em medida socioeducativa de meio aberto. É um número abismal, absurdo. Então acontece muito isso no conflito, na questão dos conflitos, como eu vou resolver esse problema. Na questão da morte mesmo, e isso é complicado.

O profissional fala a respeito de um terreno onde a morte se apresenta, se materializa, se estendo ao chão, deixa de ser corpo e sangue e passa a compor o cenário.

Inicia seu relato destacando sua posição narrativa, a de alguém que já viveu na periferia, não nos revela os motivos de ter deixado a região, mas se apresenta como alguém que comungou de um cotidiano em que a morte não é somente possibilidade discursiva, não somente compõe a travessia do imaginário (Gomes e Ramos, 2016) ao "nervoso" $\left(\right.$ Duarte, 1986; Pelúcio, 2009) ${ }^{29}$; o presentifica. Em pesquisa feita pela Secretaria Nacional de Juventude (2013), 51\% dos jovens declararam ter perdido parente ou amigo

\footnotetext{
${ }^{29}$ Enquanto Duarte (1986) apresenta a noção de nervoso como uma concepção entre o físico e o moral, pensando os contextos de vida urbana e a classe trabalhadora, Pelúcio (2009) entende que os critérios onde o "nervoso" se apresenta são dispostos cultural e socialmente, (em sua pesquisa, se articulam à questão de gênero, nas trabalhadoras do sexo travestis e trabalhadoras de prevenção). Gomes e Ramos (2016) tratam do "imaginário", produzido pelos discursos da mídia, de modo a construir o espaço urbano como espaço dos transtornos mentais, pelos discursos do trágico, da vida acelerada, "cidade nervosa".
} 
em decorrência de violência ou acidentes, sendo $21 \%$ destes decorrentes de homicídios. A pesquisa destaca que a relação entre violência e juventude indica "uma experiência geracional de alta dramaticidade". Deve-se ressaltar que a pesquisa não foi realizada especificamente junto a jovens moradores de regiões periféricas, onde se apresentaria provável tendência de aumento dos dados.

A esse respeito, Feltran (2008a) trata de uma legitimação social ao uso de violência, repressão e mortes quando ocorrem em sujeitos inscritos nos sistemas judiciários e penais, "o noticiário sempre faz questão de dizer, na contabilidade dos mortos em chacinas e ações policiais, quantos entre eles tinham antecedentes criminais, o que aparece como argumento de legitimação" (p. 324).

Agamben (2007) afirma que Foucault não teve tempo de desenvolver as implicações do conceito de biopolítica. $\mathrm{O}$ autor afirma ainda que o aprofundamento da modernidade produzira transformações das categorias políticas e filosóficas gestando a "politização da vida nua". A vida nua, para Agamben, é um conceito que se inclui pela exclusão, porque está em oposição à existência política, e somente existe porque se mantém quanto à política "numa exclusão inclusiva". O conceito se desenvolve a partir de uma noção do direito romano, o "homo sacer", categoria que se excluía da proteção jurídica. A vida nua é a "vida matável”, "incluída no ordenamento unicamente sob a forma de sua exclusão", sua "matabilidade" (p. 16).

[Entrevistado 12] - O inimigo do Estado é o negro, periferia.

- Dirá um de nossos entrevistados. Sua fala pode facilmente ser colocada de frente com o que afirma Agamben:

O fundamento oculto sobre o qual repousava o inteiro sistema político; quando as suas fronteiras se esfumam e se indeterminam, a vida nua que o habitava libera-se na cidade $e$ torna-se simultaneamente o sujeito e o objeto do ordenamento político e de 
seus conflitos, o ponto comum tanto da organização do poder estatal quanto da emancipação dele (AGAMBEN, 2007: 17).

A vida na periferia parece apresentar as contradições próprias do que Agamben nos apresenta enquanto vida пиa, a vida que passa por ordenamentos jurídicos e do Estado de modo a conformar sua exclusão em relação aos mesmos, reafirmando com frequência uma agenda de matabilidade, tornando banais ou frágeis os pactos políticos civilizatórios que nos sustentam.

[Entrevistada 14] - Eu acho que a gente não pode nem dizer que no Brasil não tem pena de morte. Ela não é legalizada, mas ela existe. Aqui, muito se resolve matando. Tem crime, mata. Ela não é julgada, ela não tá lá dentro da lei, mas ela acontece. Fora da lei, mas acontece... Inclusive nos linchamentos, sabe? [Políticas de higiene] De higiene, de extermínio, que tudo mata. Eu não vou dizer pra você que os meninos não chegam aqui também com esse discurso. Às vezes na menor briga que ele têm.

Quando a vida se desnuda, se irradia também nas relações e nos valores, de acordo com a fala da profissional, outros trânsitos entre a legalidade e a ilegalidade emergem pela narrativa da morte, do fazer morrer e do deixar morrer. Outras relações se estabelecem, de modo que o repertório de solução de conflitos se estreita.

[Entrevistada 4] - E eu fiquei pensando nisso, o quanto o Estado é programado pra fazer isso com a gente, né? Se ele não adoece, ele mata ou encarcera.

A partir deste entendimento, há todo um repertório institucional ou letal para encaminhamentos dos pobres: pela via da doença, hospitalização ou internação, pela via da "prevenção" criminal, a internação socioeducativa ou o cárcere, e finalmente pela morte, como possibilidade frequente predisposta nos territórios de desnudamento da vida.

Mbembe (2016), ao oferecer a definição sobre o conceito de necropoder, afirma que este se trata de uma formação específica do terror, isto é, de um fracasso de projeto civilizatório moderno. Utilizando, como exemplos, o apartheid e os conflitos territoriais 
palestinos, o autor fala da divisão territorial como estratégia do que denomina necropolítica, noção-chave, que utiliza para apresentar a discussão sobre configurações do poder na contemporaneidade que subjugam a vida ao poder da morte, dentre elas a produção de "mundos de morte", territórios onde, partindo de uma colonização pela violência, são implantadas estrategicamente tecnologias de "destruição máxima de pessoas". A formação de regiões de "ocupação colonial", sobre as quais o Estado, num exercício de soberania e violência, se impõe não somente pela produção do apartamento, controle e vigilância, como pela reclusão, “uma concatenação de vários poderes: disciplinar, biopolítico e necropolítico" (MBEMBE, 2016: 137). De maneira que estabelecem-se "duas geografias distintas que habitam a mesma paisagem" (p. 137), sobre uma delas pesam formas de poder que se manifestam pela violência e morte, em conformidade à lógica de produção, num sentido capital, de produto (p. 139). O autor conclui que, nestas topografias específicas, habitam "formas novas e únicas da existência social, nas quais vastas populações são submetidas a condições de vida que lhes conferem o status de mortos-vivos" (MBEMBE, 2016: 146).

\section{Matar e execrar}

[Entrevistado 12] - É o Estado matando de maneira súbita e de maneira programada.

A relação com a morte na periferia, pautada nos relatos a partir da "ausência" do Estado, ou de seus encaminhamentos institucionais, constitui, a partir de nossa leitura de Agamben numa presentificação pela via da matabilidade.

[Entrevistado 1] - E a questão do Estado, o Estado mata diretamente, mas ele mata indiretamente toda hora. Isso que é a questão, como você vai privando a pessoa de certos direitos e como isso vai custando a vida da pessoa. 
[Entrevistado 3] - Acaba matando mais por omissão que diretamente.

[Entrevistado 1] - Mais indiretamente, porque o indireto ele vai levar pro direto uma hora. A partir do momento que eu não tenho dinheiro, eu não tenho acesso à educação, eu vou traficar. Eu traficando, eu tô numa área de risco muito maior que na minha casa. Então, eu acho que o indireto leva ao direto, sabe?

Essas estratégias diretas e indiretas de matabilidade e exposição da vida nua, dialogando com o conceito de Agamben passam por um abandono sistêmico pelo Estado de suas funções no que cabe promover inclusão da população pobre, negra e periférica. Na sequência do diálogo, o profissional fala sobre a transposição desses valores nos discursos, não somente da periferia, mas da sociedade como um todo.

[Entrevistado 1] - Mas eu acho, dentro desse sentido do papo, como você vê a falta de Estado realmente em todo lugar de SP, só que como essa falta de Estado é vista do nosso umbigo. Por exemplo, eu tô vendo a criminalidade no meu bairro da Zona Central aumentar, o que eu quero que aconteça? Eu quero que esses índices diminuam, me sentindo seguro, independente do que aconteça com o resto da cidade. Então aumenta o número de policial aqui, se precisar matar alguém de fora, mata. Eu quero que a criminalidade diminua aqui, só que não entende que essa falta de Estado é aumentada três vezes em lugares afastados. Então como esse Estado ele atua menor pra mim, só que pro outro, atua muito menos. Então pra pensar uma política que diminua a criminalidade no lugar afastado, eu não quero pensar nisso, quero pensar em mim. Então isso dificulta muito.

Compreendemos que a "falta de Estado", nesta fala, se refira ao afrouxamento de valores de um pacto cidadão, no qual, conforme as expectativas de nosso entrevistado, haveria uma reivindicação por soluções na esfera coletiva para as decisões sobre questões sociais, a da segurança pública, especificamente neste recorte. Ao contrário, tais questões são tomadas “do próprio umbigo".

"Se precisar matar alguém de fora, mata". Chama atenção no trecho de sua fala, o caráter "estrangeiro na cidade" que assume a população moradora da periferia. Há, não somente vidas matáveis, como são vidas já anunciadas como estrangeiras, perigosas, execráveis. 
Foucault discorre em sua obra (2001 e 2010) sobre a constituição discursiva de classes consideradas perigosas à sociedade, ao Estado ou aos governantes, e da necessidade dos mecanismos de poder e da imposição de tecnologias de gestão e controle sobre seus corpos, em última instância o isolamento e o aprisionamento é o destino que se administra a esses sujeitos perigosos, desse modo é que se origina o sistema penal, e assim se justifica seu legado.

Queremos aqui apresentar duas possibilidades para a fala dos entrevistados nesse sentido: a primeira, que ao lidarem com esses sujeitos "perigosos", marcados pelo sistema judiciário e ainda vagantes numa zona de periculosidade e desnudamento da vida, que são as periferias, justificam-se discursos e narrativas que legitimam suas mortes dado a seu caráter execrável.

Nogueira (1998), em sua pesquisa Significações do corpo negro, afirma que existe como marca da questão racial um repertório do execrável constituído socialmente, a partir do qual, modelos do que é "desejável” se impõem sobre os corpos negros, afirmando seu caráter inaceitável, indesejável, aversivo, de recusa, negatividade, odiável. Os jovens em cumprimento de medidas socioeducativas são introduzidos nesse repertório social. Corpos em conflito com a lei, corpos negros, de periferia, execráveis.

A autora Andrea Scisleski, em seus trabalhos (2008, 2010, 2011 e 2016), convoca a teoria de Agamben a dialogar com a temática da juventude, em grande destaque à juventude em cumprimento de medidas socioeducativas. A autora afirma que o Brasil produz políticas de vida concomitantemente a políticas de extermínio, miséria, exclusão, vida e morte são "categorias políticas que se dirigem a formas de governar a vida" (p. 97). 
Santibanez et al (2015) realizaram um estudo comparativo entre entrevistas de representantes da sociedade e suas concepções sobre violência e juventude, com projetos de lei organizados nos entes federativos. Em sua pesquisa, constataram, em tramite, na Câmara dos Deputados e no Senado, 60 projetos e propostas com objetivo de reduzir a idade de imputabilidade penal (p. 319). As autoras observam que nas narrativas estudadas, os adolescentes são responsabilizados pelas situações de violência cotidiana, tanto para a população comum, como para legisladores. Nosso país não superou difíceis barreiras de desigualdades de acesso pela pobreza e pela cor da pele, e estas permanecem atreladas à história da juventude (e de sua criminalização).

[Entrevistada 14] - A gente vê que sempre tá em pauta a redução da maioridade penal, a gente não consegue descansar. É todo tempo, todo tempo, as pessoas pensando em reduzir, como se fosse a solução de todos os problemas. Fora também, falar de redução, falam também do recrudescimento das penas. Das medidas. Falam do recrudescimento, tornar tudo mais cruel, mais severo. Tem pesquisas que dizem que 3 anos que o adolescente passa privado de liberdade, corresponde a 10 anos da vida dele. E ainda se fala em se tornar 6 anos, que ele fique privado 6 anos. Então são questões muito profundas pelo menos é o que eu percebo.

Pelo período de conclusão desta pesquisa, em março de 2019, havia novas propostas sendo pautadas, dessa vez pelo Poder Executivo federal, incluindo, entre outras medidas, o aumento do rigor penitenciário e a redução da idade penal. Pensamos que a constituição dessas medidas e mecanismos de Estado mais punitivos e institucionalizantes remetem ao que o pensador Wacquant (2003) considera de "Estado penal", o qual é somente viabilizado com a redução do investimento em políticas sociais (estado de welfare ou bem-estar), em estratégias de resultados punitivos à pobreza.

Eu desenvolvi o conceito de prisonfare por analogia com bem-estar social (welfare) para designar um fluxo das políticas públicas - que abrange categorias, programas e discursos - que enfrenta as doenças urbanas, lançando mão da polícia, dos tribunais, das cadeias, das prisões e de suas extensões (WACQUANT, 2012). 
Este autor trata que estes modelos (welfare e prisonfare), ainda que opostos, tenham a mesma origem, e tendem à vigência simultaneamente, num processo transitivo constituindo uma "nova política da dupla disciplina". Até aqui, percebemos que há em circulação discursos em direções opostas, pela proteção de crianças e adolescentes; e discursos em prol de imposição de penas mais severas e maior e mais rígido controle institucional, impondo o cárcere como solução. Embora dissonantes e divergentes, os discursos, em ambas as direções, perpassam as mesmas esferas, social, política, institucional, e no sistema socioeducativo.

Há ainda outra possibilidade do entendimento acerca da gestão aos "matáveis" e "execráveis", de que nossos entrevistados, apropriados de um repertório de proteção e garantia aos direitos dos adolescentes e jovens implicados em medidas socioeducativas, se tornem, eles também, acusados pelo repertório do execrável.

[Entrevistado 1] - É uma dificuldade que a gente tem no nosso trabalho, no sentido de visão social. Porque a gente sabe que São Paulo é uma cidade bem conservadora no sentido político, e como a gente tem certa resistência, por exemplo, você vai explicar pra sua família onde você trabalha, "você defende bandido".

Alguns dos profissionais contam que não revelam para suas famílias onde trabalham, na intenção de evitar discussões ou serem taxados como "defensores de bandidos".

O profissional segue explicando, no diálogo abaixo, esse movimento que o implica num repertório do execrável enquanto atua nas políticas protetivas de direitos de adolescentes e jovens, e passa pela revisão do papel de seu trabalho pela sociedade e pelo Estado.

[Entrevistado 1] - Pra você explicar como esse trabalho socioeducativo é feito, muitas vezes ele é pegado de um jeito mais "pô, por que você tá fazendo isso"? E questionamentos, "se o cara matou, você vai defender"? Como se eu fosse um defensor. Na verdade eu tô querendo fazer justamente o contrário, tô fazendo um 
trabalho de ressocialização pra que isso não seja a recorrência. Pra que isso, se já chegou a acontecer, não aconteça novamente. É justamente o contrário do trabalho de defender bandido que você tá fazendo teoricamente.

[Você tá fazendo um trabalho que é preventivo?]. visando a...

[Entrevistado 1] - Ele não é preventivo, ele é posterior, mas...

[Entrevistado 14] - A não acontecer mais.

O diálogo pode ser lido a partir de alguns aspectos: os questionamentos feitos pela sociedade acerca do trabalho socioeducativo. Quando perguntado "por que faz isso", implica uma confrontação com a legitimidade deste trabalho, como se participasse de algo absurdo ou moralmente incorreto do ponto de vista de seu interlocutor. Em última instância, são os valores do ECA e até mesmo Constitucionais sendo confrontados nesses discursos. Ainda, quando perguntamos, a partir de sua construção argumentativa, se o trabalho é preventivo, o profissional se reinsere no papel de agente em função do Estado, ressaltando que seu trabalho não é preventivo, uma vez que a intervenção do Estado sobre o jovem implicado em situações de infracionalidade é tardia.

\section{Precarizar}

Neste cenário, onde o trabalho tem questionada sua legitimidade, inserido em transformações da sociedade que implicam a redução do investimento socioassistencial e a retomada de propostas institucionais repressivas, acontece um processo conhecido e comentado pelos trabalhadores como a "precarização" das políticas sociais, isto é, o desinvestimento pelo Estado que pode ocorrer de maneira definitiva ou gradual. 
Wacquant (2012) aponta a contiguidade das políticas do welfare e prisonfaire como um processo característico da sociedade penal, de modo que modelos distintos tendem a conviver paralelamente na organização das políticas.

Ao final do ano de 2016, o Governo Federal promulga, por meio da Proposta de Emenda Complementar (PEC) 241, um reordenamento dos investimentos em programas sociais, conhecido como "Novo Regime Fiscal", com vigência prevista longitudinalmente. Nesse mesmo período, o Instituto de Pesquisas Econômicas Aplicadas (IPEA) divulga por meio de notas técnicas alertando para o impacto e consequências desta medida na redução dos direitos à saúde e à assistência social no (PAIVA et. al, 2016; VIEIRA e BENEVIDES, 2016).

Era esperado que, com a redução de incentivos federais, os municípios, principais responsáveis no pacto federativo pelo desenvolvimento das políticas a nível regional, acompanhassem também a tendência e os efeitos desse desinvestimento. Já no período de realização da pesquisa de campo, um dos gestores informou que a execução das atividades do serviço passava por comprometimentos financeiros. Os trabalhadores mencionam, muitas vezes, indisponibilidade de recursos para algumas atividades, e para a efetivação do local como um espaço de convivência juvenil, projeto que gostariam de realizar junto ao SMSE/MA. Interpretamos que estava em curso uma proposta de redução dos serviços socioassistenciais, e, por fim, tivemos conhecimento, posteriormente, que esse movimento tendia a um agravamento com o passar do tempo. ${ }^{30}$

\footnotetext{
${ }^{30}$ Ao período da conclusão do presente trabalho, soubemos da publicação do Decreto Municipal 58.636, de 22 de fevereiro de 2019, que autoriza a redução dos valores e/ou quantidades contratados por meio dos "contratos de gestão, convênios, termos de colaboração, termos de fomento e instrumentos congêneres referentes aos serviços de ações de saúde e assistência social”.
} 


\section{Capítulo 6. CARACTERIZAÇÃO DO TRABALHO SOCIOEDUCATIVO: DOS SUJEITOS, DAS POLÍTICAS E DOS SERVIÇOS}

Neste tópico, tratamos dos conceitos que emergem a partir dos diálogos junto aos profissionais naquilo que concebem sobre as dinâmicas do trabalho, o trânsito das políticas socioeducativas junto às demais políticas, e sua relação com os jovens em atendimento nos serviços.

\section{Os trabalhadores das medidas}

Embora existam normativas tratando das áreas e funções que podem atuar junto ao Sistema Único de Assistência Social ${ }^{31}$, uma questão apontada pelos profissionais é a falta de preparo e discussões durante seus cursos de graduação.

[Entrevistada 4] Eu não conhecia medida (socioeducativa), não conheci na faculdade, nunca ouvi falar, e uma pessoa que trabalhava aqui (no serviço) na época, foi fazer uma apresentação na sala e falou superficialmente, mas na época dela nem existia os técnicos, era uma orientadora e uma coordenadora, meio que nessa mudança ai que aconteceu (transição de outros modelos para o SINASE).

O ECA e o SINASE são apontados como instrumentos de fundamental importância, porém pouco defendidos nas matrizes curriculares, mesmo em cursos nas áreas de ciências humanas e sociais aplicadas:

[Entrevistado 8] Me inscrevi, participei do processo seletivo sem muito bem saber o que era medida. Quando eu fui selecionado pra entrevista, dei aquela "revisada", fui ler o ECA, fui ler o SINASE pra entrevista em si.

Os excertos são de profissionais formados, respectivamente, em Pedagogia e em Ciências Sociais. Porém, a queixa que apresentam é comum para os egressos de outras

${ }^{31}$ NOB-RH/SUAS (Resolução 269/2006 do Ministério do Desenvolvimento Social). 
formações no sistema de medidas socioeducativas, como Psicologia e até mesmo Serviço Social. Cruz (2015) propõe que a formação profissional estimule não somente a formação acadêmica, como discussões sobre a prática e a dimensão afetiva suscitada no trabalho junto a crianças, adolescentes e jovens.

Incluir a dimensão afetiva, pois vínculos são criados, existem múltiplos sentimentos que emergem do cuidado com as crianças, os jovens, as famílias e com situações que envolvem vulnerabilidades, desamparo, fragilidades de alternativas. Em síntese, a formação precisa ser continuada e contemplar dimensões teóricas, práticas, éticas, políticas, afetivas (CRUZ, 2015: 28).

O pouco preparo nas universidades para atuação nas políticas sociais com a juventude, e especificamente, a juventude em medidas socioeducativas, demonstra, não somente pouco apreço ou valorização a este conteúdo em prol de outras questões importantes às formações, mas repercute diretamente no pronunciamento ou silenciamento de um sistema de valores que tais políticas representam. Aparentemente, os profissionais identificam, em alguma medida, a desvalorização sobre a produção de conhecimentos sobre as políticas sociais para atuação junto à juventude e ao sistema socioeducativo.

O sentimento de desvalorização é ainda apresentado em outro contexto. Um dos entrevistados afirma que o trabalhador socioeducativo tem curto tempo de "vida útil".

[Entrevistado 3] Eu não sei se pega nesse sentido, mas querendo ou não, técnico em serviço socioeducativo é um cargo muito rotativo. Talvez envolva fatores emocionais... A vida útil de um técnico é seis meses a um ano, aí quem passa disso, beleza. Mas é rotatividade nesse nível mesmo.

O profissional fala a respeito de uma desvalorização que torna sua categoria próxima a um objeto, de seu sentido como uma bateria com breve prazo de expirar. Questionado pelo entrevistador, explica que há fatores como a rotatividade que interferem, e, possivelmente, fatores emocionais. Estes últimos principalmente foram 
expressos por muitos dos técnicos do sistema socioeducativos, agravados, não somente pelo convívio com situações de violações de direitos e vulnerabilidades, mas pela escassez de recursos institucionais para atuar sobre as mesmas, de modo a perceberem menor efetividade do trabalho executado.

Compreendemos que existam dinâmicas de micro e macrogestão que possam talvez interferir no sentimento de desvalorização. Na época da pesquisa de campo, já havia resoluções municipais de congelamento e redução de investimentos nas políticas da SMADS. Posteriormente, essa situação se acirraria, provocando políticas de redução salarial, demissões, descredenciamento de organizações e fechamento de serviços ${ }^{32}$.

$\mathrm{Na}$ interação entre o entrevistador e os profissionais, foram discutidas também propostas de fortalecimento para lidar com a complexidade das questões identificadas. Além das estratégias de gestão das equipes, dos espaços para compartilharem e discutirem abertamente essas questões, apresenta-se como opção também a articulação das questões do trabalho com a militância em coletivos e movimentos de participação social.

[Entrevistado 8] De fato eu considero que é uma sorte do mundo de ter ido trabalhar num espaço muito aberto à articulação, a pensar a relação do trabalho junto à relação da militância. Tanto que a própria equipe falou: "pra trabalhar aqui tem que ser militante". Eu acho que de algum modo isso contribuiu na minha trajetória, porque eu já vinha de uma trajetória de movimento social, de movimento negro, de participar de movimento de moradia.

Se comparadas as falas dos dois profissionais, vindos de diferentes equipes e contextos, poderia se pensar que o trabalho articulado à militância é a "sobrevida" em resistência à objetificação.

\footnotetext{
${ }^{32}$ Após a realização do campo, já no período de conclusão do presente trabalho, no início de 2019, falavase em políticas de redução salarial para os prestadores de serviços que trabalham em organizações ligadas à esta Secretaria. Ainda, como consequências ao Decreto 58636/2019, anteriormente citado, ocorreram reduções de equipes e demissão de trabalhadores, descredenciamento de organizações (entre elas, uma das que colaboraram nesta pesquisa), e fechamento de serviços da rede socioassistencial, incluindo parte dos SMSE/MA.
} 
A equipe destaca ao profissional a necessidade de articular as questões do cotidiano profissional a discussões da esfera sócio-política, não haveria, na proposta apresentada por esta equipe, um descolamento da realidade profissional com a bagagem pessoal, sendo que a atuação em movimentos sociais surge como demanda.

[Entrevistada 14] - É meio que a gente não tem muito descanso na verdade no quesito luta. Você tem que tá lutando o tempo todo. Fora uma luta contra a sociedade que é altamente punitiva. A sociedade quer punir, punir, punir, e não percebe os problemas estruturais. Não percebe que nessa sociedade a gente tem problemas de sistema mesmo. A gente no movimento [social] escuta muito dizer "eu não sou pobre, tem um sistema que me empobrece".

Nesse regime de "dupla disciplina" (Wacquant, 2012), entre as propostas de proteção e sob as restrições da ascensão de propostas punitivas, o trabalho assume a dimensão da "luta", não somente institucional, luta pela mudança social, para que a sociedade compreenda de modo mais crítico questões sociais complexas.

A necessidade de fazer um trabalho para além do burocrático é identificada nas equipes que colaboraram com esta pesquisa. Embora, pelo apontamento desse caráter excepcional. Nem todas as organizações sociais atuantes em medidas socioeducativas, tanto no meio aberto como na Fundação Casa, assumem essa mesma perspectiva, concorrendo com outras práticas e propostas mais conservadoras, há relatos de profissionais e gestores com ligações policialescas ou religiosas.

[Entrevistado 8] Você tinha me perguntado se seria diferente a minha fala em outro contexto. De fato, seria. Porque são 60 serviços, e tem serviços que o gerente do serviço é ex-delegado, sabe? Tem serviços com pessoas extremamente conservadoras, que pensa dentro de uma lógica de punição, sabe?

A gestão local tem, dessa forma, um papel importante na condução da perspectiva do trabalho, se por um lado, a medida em meio aberto poderá ser burocrática, ou ter um sentido mais conservador, reforçando a moral e a "culpa", reafirmando discursos penalistas; também poderá ser mais militante e apresentar 
discursos em defesa dos direitos humanos e sociais, como as equipes e profissionais que dialogaram nesta pesquisa.

Comentamos essa observação a uma das equipes, e recebemos como resposta que: “É a gestão! É muito particular". É quando o gerente desta mesma equipe, que participava do grupo responde: "E também vem de um movimento de equipe, não adiantaria nada eu tá falando, falando, falando, se a equipe não abraça”.

Carmo (2017), em sua pesquisa junto a um dos SMSE/MA na Zona Sul, indica que muitas das diretrizes do SINASE, enquanto política, instrumentalizam as práticas para a individualização da responsabilização e das estratégias junto ao jovem em cumprimento de medida. A pesquisadora destaca que são as equipes que buscam estratégias que admitam fugas à burocratização, imposta, não somente pelos instrumentos do SINASE, como para certa dinâmica conservadora na esfera da sociedade. "Nas tentativas de aproximação entre coletivos, jovens atendidos e técnicos, parece acontecer certa flexibilidade na relação técnico e atendido, surgindo outra figura, que é a do ativista" (CARMO, 2017: 103).

\section{As instituições das medidas}

Os serviços de atendimento de medidas socioeducativas em meio aberto visam implementar modelos alternativos ao histórico de aprisionamento juvenil que percorre as instituições brasileiras. Essa nova configuração pretende ofertar inclusão em programas de assistência social, promoção de direitos humanos dos jovens, e integração junto a políticas públicas sociais (SINASE, 2012). 
Ainda que hajam as políticas e resoluções federais e municipais, em seus discursos, os trabalhadores do sistema de medidas socioeducativas identificam a falta de uma caracterização nas práticas:

[Entrevistado 8] De fato não existe um modelo de orientação do que você vai fazer na medida. Apesar de ter Plano Nacional, apesar da tipificação, apesar de haver documentos explicando, ele não esclarece, não define muito bem como deve ser a prática a partir de uma perspectiva burocrática. Então de algum modo você vai aprendendo a trabalhar ali enquanto vai vivenciando. Você vai aos poucos aprendendo o que é a medida, o que compreende o trabalho da socioeducação. Tanto que a gente faz curso de capacitação, supervisão. E faz parte da política ser acompanhado, ter capacitação, supervisão, formação técnica, pra entender de algum modo como são as orientações da política. Foi assim que fui começando a ter esse manejo.

Ficaria a cargo da gestão dos serviços um trabalho contínuo de formação dos profissionais do sistema socioeducativo, de modo ao desenvolvimento de perspectivas que direcionem aos valores do ECA e do SINASE e à defesa da proteção integral. Ainda assim, o mesmo entrevistado identifica que este alinhamento não se dá na prática com todos os serviços e trabalhadores da medida.

[Entrevistado 8] Você tem serviço [de MSE] [...] que tá ali dentro de uma relação burocrática. A gente senta ali, trabalha 8 horas por dia, trabalha das 08 às $17 \mathrm{~h}$, e faz os atendimentos individuais, e escreve o relatório enfim. Por exemplo, menino que vem de outro serviço, porque vai morar lá no território, a gente pega, você vai ter acesso ao relatório anterior é tipo, sei lá, o menino fuma maconha e fala: "o menino é usuário". E pensa no PIA [Plano Individual de Atendimento], faz encaminhamento para o CAPS porque o menino fuma maconha, sabe? Tem essa perspectiva de olhar a droga a partir de um problema de segurança pública, enfim. Olhar pro uso de droga dentro dessa lógica moralista.

O PIA é o mecanismo que intermedia a relação entre o serviço de medida em meio aberto, ligando a rede municipal socioassistencial com o sistema estadual de justiça. Carmo (2017) aponta o caráter burocratizante que o instrumento pode assumir na condução das estratégias do trabalho e, portanto, na vida dos jovens atendidos nos serviços. "Normatização dos adolescentes que cometeram ato infracional: escolarização, 
inserção no mercado de trabalho, reforço dos vínculos familiares, arrependimento pelo ato cometido" (p. 95). A autora critica, sobretudo, a redução das práticas ao teor documental e o potencial em converter-se numa ferramenta livre de crítica, esgotando a questão da medida socioeducativa no jovem que está sob seu peso.

Ao mesmo tempo, muitas equipes e profissionais assumem esse instrumento também como "espaço de luta, em que é possível fazer denúncias e tornar explícitas as contradições" (Carmo, 2017: 95).

Deste modo, entendemos que a condução de uma mesma política, salvo as necessidades contextuais locais, pode ser direcionada de modos bastante diversos e até contraditórios, pensando aspectos como conservadorismo e resistência, punitivismo e proteção social, preconceitos e afetividades, defesa e violação dos direitos. Isto fica evidenciado nesta outra fala:

[Entrevistada 14] Pensando no quesito juventude, medidas (socioeducativas), é bem delicado. Porque, ao mesmo tempo em que algumas coisas são avanço, como o SINASE... SINASE regulamenta muita coisa que antes era muito solto, cada um fazia do jeito que queria. Mas aí também, colocar isso em prática a gente sabe que é outro processo. E ao mesmo tempo a gente vê algumas coisas acontecendo que, pra quem é defensor dos direitos humanos, defensora, são retrocessos.

A regulamentação dos serviços é vista de maneira quase contraditória, é necessária, pois representa avanços em termos de distribuição de direitos sociais, mas é também uma possibilidade de burocratização das medidas e individualização das responsabilidades. Ainda, o SINASE apresenta um paradigma, defende abertamente direitos e valores em torno do entendimento do adolescente implicado em medida socioeducativa; na prática, ainda há agentes que, movidos por concepções mais conservadoras ou seguindo questões institucionais, duvidam desses princípios, 
produzindo o que os entrevistados identificam por retrocessos, de ordem moral ou burocrática.

[Entrevistado 16] Pensando questão de rede, quando a gente pensa sempre em fluxo. "Qual é o fluxo? O Fluxo"? ... Mas pra mim, cada vez mais, a gente fala de pessoas, se a gente aqui tem um contato, facilita a vida, ajuda bastante.

Neste ponto, percebe-se que o Estado e suas políticas tem uma unidade fundamentalmente fragmentada, uma vez que seus agentes se tornam seus representantes. A articulação entre as diferentes políticas se torna mais complexa. Assim como proposto por Foucault (2010), em sua definição acerca da capilaridade do poder, os arranjos de poder, que neste caso representam o Estado, tratam-se fundamentalmente de relações mais ou menos coordenadas (p. 248). O "trabalho em rede", preconizado pelas políticas sociais, e fundamental, conforme a integralidade protetiva prevista nos dispositivos legais, como o ECA e as políticas de assistência social, é apontado como um trabalho com pessoas, de pessoas.

[Entrevistado 3] - Como você falou né, de articulação de rede, parceria. É mais ou menos o que acontece na saúde também. Aquela parceria que existe, a rede existe...

[Mas é quase informal?]

[Entrevistado 3]- Mas é informal.

Desse modo, o trabalho articulado entre serviços de saúde, educação e mesmo com outros serviços socioassistenciais perpassa atravessamentos morais e burocráticos de pessoas e equipes.

[Entrevistada 14] - E ainda seriam criminalizados se soubessem de onde eles vêm. Ainda tem isso. A gente tem que trabalhar, não podem saber que os meninos são daqui porque senão já vem problema. Escola, a gente tem um impasse aqui, se a gente não encaminha, às vezes o menino não consegue vaga. Se a gente encaminha, ele é daqui, ele é criminalizado porque é daqui. São bem tensas as relações, sabe, nesse sentido, bem conflitantes. 
Acontece uma produção de identidade perigosa nos discursos institucionais, essa suposição da periculosidade dos sujeitos (FOUCAULT, 2001, 2010; MATSUDA, 2009) tende a estabelecer mais barreiras.

[Entrevistado 1] Você vai na escola. Vamos fazer a matrícula do menino. "Ah ele é L.A."? Então você ainda tem essas figuras nos espaços públicos, e nos espaços privados também. Acaba acontecendo em outros serviços da Assistência [Social] mesmo.

O trabalho junto ao Poder Judiciário é um dos mais tensionados nos discursos.

[Entrevistado 12] A juíza tá numa audiência com o menino e fala, "estudar é bom, olha onde eu tô". Quem é a juíza, quem é o menino?

Agentes do Poder Judiciário aparecem nos discursos com pouca disposição de contextualização, reforçadores de aparatos burocratizantes e moralizantes, que desconsideram as origens sociais e territoriais dos jovens. Após esta fala, os entrevistados reforçam que os suportes econômico e social, que acompanham a trajetória de vida que a levou a ocupar sua atual posição enquanto juíza, certamente diferem e se distanciam da realidade dos jovens atendidos na Zona Sul de São Paulo.

[Entrevistada 14] - A gente não consegue ter uma ação conjunta com [Poder] Judiciário, que o Judiciário encaminhe também pra profissionalização. A gente tem que fazer tudo, basicamente. Eles só querem que a gente faça, mas não querem saber como vai fazer. Ou o que a gente vai fazer.

[Entrevistado 3] - Mas talvez, até se encaminhasse pra profissionalização. Não seria na região, porque não tem.

A fala aponta resíduos de uma compreensão, da parte de agentes do Poder Judiciário, das estratégias de inserções produtivas-ocupacionais como supostas soluções à infração à lei, o trabalho como suposta correção à "vadiagem”. Os profissionais do sistema de medidas socioeducativas acabam por responder a esta lógica, ainda que identifiquem sua limitação. 
[Entrevistado 16] - O judiciário, ele precisa de uma condição pra liberdade, e tem o tripé: A escola, o trabalho e curso profissionalizante. Se não tem nenhum desses três, o trabalho socioeducativo não aconteceu. E tem outras necessidades, mas que para o Poder Judiciário não são levados em conta. A nossa posição, como serviço, o que a gente sente, o que a gente percebe é que o que a gente fala não é levado em consideração. Então, essa é a nossa querida rede.

A fala a seguir trata de um trabalho de insistente comprovação de conhecimentos técnicos, e da necessidade de compreensão do Estado a partir de seus agentes, isto é, o trabalho "em rede" só acontece enquanto trabalho com determinados agentes atuantes nesta rede:

[Entrevistada 4] - A gente precisa se moldar um pouco também, a nossa escrita de relatório técnico, enquanto aquilo que o juiz espera que a gente escreva. Às vezes a gente consegue alguns ganhos, de bancar e escrever uma, duas, três vezes, pedindo a mesma coisa. Veio "não", e a gente tá correndo atrás do sim, porque, de certa forma, a gente tá reforçando nosso posicionamento, enquanto profissional que tá atuando diretamente com adolescente, e tá embasado no que tá sendo realizado. Já teve casos de a gente sugerir encerramento [da medida socioeducativa], a Defensoria [Pública] ser a favor também, argumentando que o trabalho que a gente faz é um trabalho com um olhar profissional, e se a gente tá sugerindo, é porque a gente tem embasamento pra isso, e de a gente conseguir. Mas é isso, vem "nãos" também. Teve um caso agora que a gente conseguiu no terceiro relatório, que a gente tava pedindo encerramento, a gente conseguiu. Só que o juiz chamou todo mundo pra audiência pra conversar. A família, a gente e tal, e saiu. Conseguimos: sem escola, sem trabalho, sem nada! Mas também vai muito do juiz que tá analisando, talvez esse juiz tenha um olhar um pouco diferente, algumas coisas que eu vi dele, de decisões dele, percebi que ele tem um olhar diferente, mas a gente depende muito de quem tá lá lendo o relatório.

A profissional fala de estratégias que escapam ao burocrático, mas conta com critérios pouco objetivos para o sucesso, que passa também por um questionamento argumentativo, feito pelo Poder Judiciário, da efetividade técnica dos profissionais e do trabalho socioeducativo desenvolvido no acompanhamento dos jovens no cumprimento da medida em meio aberto. 
Muitas vezes, as medidas são impostas pelo Judiciário seguidas, ou de um endurecimento com critérios pouco claros, como a internação em situações infracionais onde esse mecanismo não seria recomendado, ou das chamadas "medidas sobre medidas", "cumulada", acúmulos de penalidades com vistas a aumentar o tempo de institucionalização dos jovens apenados, por meio de longo tempo de internação, seguindo-se a medidas cumulativas em meio aberto.

[Entrevistada 9] - São essas propostas de repressão, que é reduzir a idade penal, com isso vou encarcerar mais cedo, mais meninos. Ou eu aumento o tempo de internação. As propostas são essas, são sempre voltadas pro cárcere, então o que a gente vê no momento, propostas de encarceramento em massa, e falar sobre isso é importante.

[E vocês têm visto isso aqui?]

[Entrevistada 9] - Sim, é o que mais tem. Adolescentes que ficam 2 anos em internação. E uma coisa que me incomoda muito, que particularmente eu não consigo entender, é que a gente, numa perspectiva de defesa, de proteção, a gente pune. Porque, por exemplo, o que acontece em relação à Fundação Casa? O que a gente mais tem são meninos que saem de lá e vem pro [meio] aberto, se a medida ela é única, então o menino ou a menina fica um ano de internação, entende-se que ele ou ela já cumpriu com a sua pena, cumpriu a medida. Mas não, ele sai com progressão, e a justificativa da progressão da medida do meio aberto, da L.A., é o quê? Pra desinternar antes, pra reduzir o tempo de internação, eu sugiro que ele saia, mas que continue com uma medida no [meio] aberto. É muito complicado isso! Pra proteger, pra desinternar esse menino, eu continuo tendo uma ação que continua sendo punitiva. Os meninos saem de um ano de internação e vem pra L.A.

[Entrevistada 10] - Tem casos de meninos assim, estavam em meio aberto, cometeram um novo ato e foram pra internação, ficaram mais de um ano de internação, saíram da internação e voltaram pro meio aberto. É como se, pra ele sair, tivesse que ter a indicação do meio aberto. Não sei se é uma estratégia da galera que trabalha no [meio] fechado, pra dizer "se for assim é mais fácil se encerrar [a medida]", ou se realmente é o fluxo...

[Entrevistado 12] - Ele fica um ano e pouco na Fundação Casa, privado de liberdade, ai ele sai e pega duas medidas: Uma liberdade assistida e pega uma prestação de serviço. Ou seja, ele tem que vir pra cá e ficar 6 horas cumprindo prestação de serviços, além do L.A., que muitas vezes, eles [O Poder Judiciário] impõem essas condicionantes pra encerrar a medida, coisas que tá meio que, não tá previsto ali. Por exemplo, "só vou encerrar a medida se o menino 
tirar documentação ou estiver inserido na escola", mas não considera as dificuldades da escola. Ou: "só vou encerrar a medida se ele estiver trabalhando", mas com 15 anos?! Não faz sentido! Mais um pouco o Judiciário tá reforçando o trabalho infantil. Então é muito louco isso...

Pelos relatos dos profissionais, podemos pensar em fatores que se apresentam no trabalho socioeducativo, como estratégias de endurecimento das medidas em respostas que resultam num encarceramento por acúmulo de medidas, a retirada de contexto das questões sociais, territoriais, raciais, e de gênero, que atravessam os corpos dos jovens implicados em atos infracionais, assim como propostas de trabalho que quase se confrontam, entre o Poder Judiciário e os serviços socioassistenciais municipais, resultando em limitação dos recursos e, em última instância, numa relação de poder que implica na subordinação e desqualificação do segundo pelo primeiro. Scisleski (2010) dirá que "a instituição judiciária funciona através de um "alargamento" de suas funções. Isto é, a proliferação de especialidades do saber que passam a ocupar-se de atividades normalizadoras e sancionadoras dos certos tipos de comportamento, tais como a pedagogia, assistência social, psiquiatria e psicologia, por exemplo” (p. 26).

\section{Os meninos "sob medida"}

Um dos profissionais interlocutores da pesquisa nos diria em determinado momento que os meninos não vêm para a medida porque querem, "ela é imposta", “depois eles acabam gostando", criando um vínculo com o espaço e profissionais, mas em primeiro momento ela é punitiva.

Munhoz (2014) descreve como o trabalho socioeducativo, mesmo na

modalidade em meio aberto retoma mecanismos de controle. Acontece "a indissociabilidade entre a punição e a transformação", esta autora identifica, na organização do sistema socioeducativo, desde a imposição da medida pelos tribunais, 
até os procedimentos realizados pelos MSE/MA, certa falta de uma "reflexão sobre como e o quanto punir para poder transformar os meninos das medidas em indivíduos (res)socializados” (p. 171). Finalmente, a autora nota processos de gestão e controle dos jovens nas dinâmicas do cumprimento da medida socioeducativa, "encaminhando-os e transformando-os em indivíduos previsíveis, disciplinados e vigiáveis, mesmo que em liberdade" (p. 172).

A partir dos relatos dos profissionais, entendemos haver de fato mecanismos de gestão e controle, articulados a processos múltiplos, que passam pelas trocas relacionais feitas junto às equipes, pela singularidade das experiências, há relatos de jovens que encerraram a medida e mantêm o vínculo com os serviços, assim como outros que desenvolveram "aversão" ao serviço ou ao técnico que os acompanhava. Cruz (2015) afirma que as instituições são complexas e podem ser lidas por vários matizes, tendo "múltiplos sentidos para os diferentes sujeitos" (p. 30). Dessa forma, o trabalho das instituições de MSE/MA visitadas acaba resultando numa proposta ambígua, que é pautada, todavia, na "restrição de liberdades", e por outro lado, pode ter potencial efeito no acesso aos direitos e na constituição de vínculos.

\section{A semântica do "menino" e a semântica do "bandido"}

[Entrevistado 1] - A questão do preconceito mesmo que existe com a MSE. Querendo ou não, eles ainda são taxados como "os meninos da LA". Então qualquer lugar que você vai, espaço, que se tem conhecimento disso. Isso é colocado, exposto.

"Atendido", o "adolescente", o "jovem em conflito com a lei”, "L.A."33, em campo são termos que se destacam para se referir aos sujeitos em atendimento nos

\footnotetext{
33 Jovem em cumprimento de medida socioeducativa em meio aberto, a sigla abrevia o nome de sua medida, "liberdade assistida".
} 
serviços do SINASE. Nos serviços de medida socioeducativa de meio aberto visitados, é frequente chamá-los, somente, "meninos". Por outro lado, quando passam pela internação junto à Fundação Casa, ocorre o processo que aqui denominamos "semântica do bandido".

Nos equipamentos de meio aberto, observa-se a construção de uma semântica afetiva discursiva, relacionada à produção de vínculos junto aos jovens em atendimento socioeducativo.

$$
\begin{aligned}
& \text { [Entrevistada 14] - Aqui a gente ainda diz assim "os meus } \\
& \text { meninos". } \\
& \text { meu”! } \\
& \text { [Entrevistada 6] - A gente ainda briga por causa deles. "Esse é } \\
& \text { apegada. }
\end{aligned}
$$

A semântica do menino de que tratamos reconstitui o sujeito atendido de seu lugar numa etapa cidadã "em desenvolvimento", transmite não somente a ideia de proximidade afetiva, simultaneamente, ainda nos reapresenta uma ideia de direito à infância / adolescência / juventude do qual o sujeito esteve ou ainda está privado tardiamente. Entende-se que este ato desprovido de interesse pode se inserir numa produção política-identitária que legitima a esses meninos um lugar na sociedade. É também pautado por aspectos geracionais ${ }^{34}$, que situam o "menino" em determinada faixa etária que o diferencia do profissional de referência. Finalmente, remete ao processo denominado por Vicentim (2012) de "criançar o descriançável", na definição desta autora, a partir dos neologismos, trata de processos onde a abertura para vivência ou experiências de infância e juventude passaram por "sufocamentos", "limitações", destacadamente, a partir de contextos de institucionalizações, "criançar" essas vivências

\footnotetext{
${ }^{34}$ Autores das ciências sociais se dedicam ao debate bastante estabelecido sobre as teorias geracionais (Mannheim (1982), Forachi (1972), Pais (1990), Weisheimer (2014).
} 
é, para a autora, estabelecer uma aliança visando assegurar seus direitos a "serem" crianças e jovens.

$\mathrm{Na}$ contramão, em suas passagens pelas unidades da Fundação Casa, esses mesmos sujeitos poderão conviver com a alcunha de "bandido" ou "ladrão", conforme me explicam as profissionais atuantes nos projetos educativos junto ao sistema de medidas em meio fechado. Contam da prática de alguns dos agentes trabalhadores daquela Fundação que, ao se reportarem aos jovens em cumprimento de medida de internação, dirigem-se a eles num contexto de subordinação. "Bandido, abaixa a cabeça"; "bandido, faz isso, faz aquilo"; “o que você quer, ladrão?". É o que denominamos aqui "semântica do bandido".

Uma das profissionais entrevistadas fala que a relação do jovem com os trabalhadores do sistema de internação ainda é a mesma da época da FEBEM, “cabeça baixa”, e respondendo com “senhor”, "sim, senhor, não, senhor”. Uma relação de submissão que é punitiva e remete ao encarceramento, teria, talvez, a proposta de atualizar constantemente o delito ao cumprimento da pena, e remete às concepções de irregularidade do contexto daqueles adolescentes.

Encontramos, no interior do pensamento foucaultiano, quando o mesmo apresenta o conceito de práticas discursivas um sentido a respeito dessas relações semânticas. O autor define por "práticas discursivas" o domínio constituído por diferentes objetos que irão definir um saber, este, por sua vez pode ser científico ou não, “um saber é também o espaço em que o sujeito pode tomar posição para falar dos objetos de que se ocupa em seu discurso" (FOUCAULT, 2008: 204).

O referencial do enunciado forma o lugar, a condição, o campo de emergência, a instância de diferenciação dos indivíduos ou dos objetos, dos estados de coisas e das relações que são postas em jogo pelo próprio enunciado; define as possibilidades de aparecimento 
e de delimitação do que dá à frase seu sentido, à proposição seu valor de verdade (FOUCAULT, 2008: 103).

Para Foucault (2008), mostrar como se forma uma prática discursiva (arqueologia) é revelar como esta é envolvida em "comportamentos e estratégias, que dão lugar a uma teoria da sociedade e que operam a interferência e a mútua transformação de uns e outros" (FOUCAULT, 2008: 218). Ainda a respeito da "semântica do bandido", de que tratamos, acaba sendo reutilizada entre os jovens em internação em seus diálogos uns com os outros, conforme relatam as profissionais atuantes nestas modalidades de medidas socioeducativas. Desse modo, é possível pensar que as semânticas relacionais, dadas nas práticas discursivas, produzem um campo précientífico de saber, do que aquele jovem e seus interlocutores sabem sobre o mesmo, do que o jovem sabe de si.

Um saber é também o campo de coordenação e subordinação dos enunciados em que os conceitos aparecem, se definem, se aplicam, se transformam [...]; finalmente, um saber se define por possibilidades de utilização e de apropriação oferecidas pelo discurso (FOUCAULT, 2008: 204).

Ocorre um movimento de transformação das práticas discursivas a partir do "saber de si" que emerge dessas semânticas. O jovem fala de si mesmo, em diferentes posições discursivas, de acordo com as relações que estabelece com aqueles que falam sobre si.

Num primeiro momento, interpretamos a "semântica do bandido", partindo do referencial estabelecido pela teoria queer. ${ }^{35}$. Porém, os relatos apontam para outras

\footnotetext{
${ }^{35}$ As teorias queer são estudos principalmente ligados às identidades de gênero e diversidade sexual. $\mathrm{O}$ termo queer, em inglês, significa "bixa", um modo pejorativo de se referir a homossexuais, travestis e transgêneros, que passa pela desconstextualização e ressignificação em seu uso por esses mesmos grupos identitários. Pereira (2006) dirá que apropriando-se de uma expressão pejorativa (queer) para autodesignação, é possível o deslocamento que descontextualiza os sinais de abjeção terminológica, e assinalar as diferenças repetindo e reiterando as vozes acusatórias, de modo a transgredi-las, criando algo novo.
} 
possibilidades no campo das identidades. Um dos profissionais entrevistados reflete sobre tais práticas discursivas:

[Entrevistado 1] - E ainda mais na adolescência, [...] no sentido de construção de identidade, - eu vou absorver alguma coisa em que me reconheço. Então, "eu não sei o que eu sou, se você tá me falando que eu sou isso, e eu vou ser alguém sendo isso, eu vou ser isso, eu vou vestir essa camisa".

Sua fala indica que a adolescência permite uma abertura identitária processual; moratória onde, da falta de conhecimento acerca de si, se desenvolve a identidade a partir das práticas discursivas e relacionais.

[Entrevistado 1] - E tem a questão da identidade, né? Por exemplo, eu tive a experiência de ir com eles no cinema. O que ele vai fazer? Se tá todo mundo me vendo como bandido, eu vou ser bandido. Vou pôr a minha camisa da minha quebrada, vou andar lá [no cinema] de óculos escuros. Eu já tô sendo estigmatizado por isso. Reforço de identidades é muito... ainda mais em grupo isso acontece.

Entender-se pertencente a determinado grupo investe o jovem de critérios que, na fala do entrevistado, "reforçam" a identidade, sustentam enunciados e revestem conceitualmente esses saberes de si.

Nesse sentido, cabe uma revisão das noções propostas pelas políticas públicas para juventude. Num dado momento, opta-se pela substituição da nomenclatura "menor", a qual tachava uma incapacidade a partir de critérios etários e designava aqueles assistidos por seus programas e serviços numa condição de irregularidade, estabelecida, ou em decorrência de seu ato infracional, ou pela sua condição social pobre. Transita-se por esses saberes (e dizeres) para a compreensão das subjetividades em suas respectivas etapas de desenvolvimento: "em desenvolvimento", ou seja, numa moratória subjetiva e constitutiva, que em última instância será garantidora de sua cidadania, e pensaremos o sujeito adolescente ou jovem como sujeito de direitos. 
No entanto, diversos outros saberes percorrem os jargões e enunciados e atualizam a "menoridade" dos sujeitos a partir de, ora um sistema cuja compreensão passa pelo afetivo, que lhe humaniza e inclui na sociedade enquanto "menino"; ora por um linguajar que lhe resguarda seu lugar entre os delitos e as penas: "L.A.”, "ladrão", "bandido"; neste caso, crime e punição antecedem sua apresentação pessoal ao mesmo tempo que a constituem.

Percursos relacionais descritos por enunciados e discursos posicionam o jovem com relação a seu lugar de infrator. No sistema de medida de internação, cabe lembrá-lo que está encarcerado, respondendo por uma situação análoga à criminal, cabe desenhar o que tem pela frente de modo a situá-lo à margem da sociedade, marginal.

Em instituições de meio aberto, certamente não em todas, mas naquelas que foram escopo desta pesquisa, pode ter a chance de resgatar direitos então renegados à convivência comunitária, a desenvolver vínculos de afeto, e até mesmo retornar a um ponto onde não tenha pré-definido seu lugar diante do mundo, a não saber bem quem é ou quem será, e assumir que não sabe. Poderá ser menino, ao menos em um lugar da sociedade, uma vez que, conforme veremos a partir dos relatos e histórias, essa estratégia nem sempre alcança o êxito no que trata da vida em todas suas esferas, lugares e atividades.

Uma vez que assumimos que produções narrativas e relacionais têm efeitos identitários, são verdades estratégicas produzidas e contextuais, há ainda outros agentes que indiretamente vão se relacionar ou discursar direta ou indiretamente a respeito desses jovens. Interessa a perspectiva do pesquisador social, uma vez que seu discurso concorre numa teia com as demais produções semânticas, e tendo isto à frente, pode também assumir seu lugar no discurso (Passos e Benevides, 2009), comprometendo-se 
com a descrição da juventude, seu cenário percurso e implicações, ou ainda, descrever a infração e seus estereótipos.

\section{Estar envolvido}

Outra relação semântica, que surge subordinada à semântica do bandido, é a do "envolvimento". "Eu não sou bandido mas eu sou envolvido" ${ }^{36}$, anuncia o refrão de um funk, estilo musical bastante presente e popular, não somente nas periferias, como em todos os bairros da cidade.

Interpretamos a relação entre a semântica do "bandido" para a semântica do "envolvido" numa relação de transição. Chama atenção na escolha desta adjetivação a alusão direta que faz ao caráter vincular, relacional, seu sentido remete imediatamente a “estar envolvido com alguém".

O “envolvido", neste contexto, presume-se envolvido com dinâmicas de práticas consideradas crimes, principalmente, o tráfico, e relações ligadas ao contexto criminal. No entanto há uma consciência de natureza ambígua por parte do envolvido. Como segue no relato de uma das profissionais do sistema de medida socioeducativa que colaborou na pesquisa, aqui a chamaremos de Nanã:

[Entrevistada 13] - Ele era super envolvido, ele vinha e falava pra mim, "eu tô te falando porque eu confio em você, eu tô super envolvido ainda, então tudo que você puder fazer por mim vai ser bem recebido, mas eu tô super envolvido" ... Sempre deixou isso bem claro. É o segundo menino que tá super envolvido, que eu pego no serviço desde que eu entrei. Então, dois casos que mais me chocaram foram esses dois adolescentes que eu perdi. Um, diretamente, que eu atendia. E ele sempre falava pra mim, "eu tô envolvido, qualquer ação que você fizer pra mim, vai ser inválida"... Em um mês, ele começou, ele ligava pra mim, "olha, Dona Nanã, eu não vou aí porque vou num velório de um amigo, que faleceu". Na outra semana, "olha, eu não vou aí, porque vou num velório de um amigo meu, que faleceu".

\footnotetext{
${ }^{36}$ Artista: Mc Maneirinho. "Mesma maconha que eu fumo, seu filho fuma também”. Produção: Funklândia, Rio de Janeiro, 2014.
} 
Terceira semana, "eu não vou al"; eu falei: - você vai em outro velório? - "Não, dessa vez, eu vou levar minha avó no médico, porque eu tenho que correr com ela, pra cima e pra baixo". Tá bom. Aí ele ficou duas semanas sem dar notícia, na realidade, três semanas. Eu falei assim, vou ligar pra saber o que tá acontecendo. Aí eu liguei, a vó atendeu. "- Alô, aqui é a Nanã, eu sou a técnica do [MSE], [seu neto], ele não tá vindo, eu preciso conversar com ele"; - "Você é técnica dele, você não tá sabendo?"; - "Não, o que aconteceu"? - "Se você é técnica dele, você precisa saber então, um hora dessas [ele] tá debaixo da..."

O "envolvido" aparentemente atravessa a medida socioeducativa, reafirmando, em primeiro lugar que o "crime" não seria talvez seu desejo, caso houvesse disponibilidade de ofertas mais vantajosas no campo da licitude. Não se considera, por completo, um criminoso; ainda que se responsabilize parcialmente pela conduta infracional, buscaria engajar-se em outros "envolvimentos" se disponíveis em seu repertório de possibilidades. Outrora, expõe contradições sobre o sistema de medidas socioeducativas, afirmando que as estratégias de inclusão não estão dando conta de “des-envolver" os envolvidos, provendo insuficiente inclusão (de renda, principalmente).

Feltran (2008a e 2008b) fala sobre a disputa de legitimidade na esfera social que oferece nas periferias sentidos diferenciais entre os "bandidos" e os "trabalhadores". De fato, para discorrermos sobre o "envolvido", a análise careceria de complexidade, uma vez que nem em todos os casos, embora estes sejam a maioria entre os relatos, a falta de acesso à renda é o argumento que sustenta o envolvimento infracional. Os relatos demonstram, porém, que há uma variada dimensão de fatores que atravessam esta questão. 


\section{Racializar os sujeitos}

É relevante que a partir das entrevistas, percebe-se que se fala muito a respeito de jovens negros de periferia. No entanto, a questão racial não parece posicionada nos discursos de modo a organizá-lo nas práticas dos SMSE/MA. A maioria dos entrevistados afirma ser notório que os jovens em cumprimento de medida, que acompanham, são negros e pardos; no entanto, não há uma precisão de dados, o que supõe a falta deste critério nos cadastros e levantamentos de dados locais e gerais.

Embora conste entre as prerrogativas, a nível federal, por meio do eixo denominado "Diversidade étnico-racial, gênero e orientação sexual", o SINASE indica nove pontos de ações afirmativas para o sistema socioeducativo nos três níveis federativos, incluindo: "inserir, obrigatoriamente, nos arquivos técnico-institucionais dos adolescentes o quesito cor" (SINASE, 2006). Ao que os informantes da pesquisa sinalizam, não há instrumentais (fichas de atendimento, sistemas de informação e gestão utilizados) que promovam a inclusão dos critérios raciais. Ações programáticas que discutem a questão racial costumam ser pontuais, geralmente ligadas ao mês de novembro e ao Dia da Consciência Negra, conforme os relatos.

A tendência a "burocratizar" o critério racial parece muitas vezes deixar as possibilidades abertas ao crivo do profissional. Uma das entrevistadas, atuante nas medidas socioeducativas em meio fechado, afirma que, antes de iniciar o trabalho com suas turmas, costuma, por iniciativa própria, passar um questionário estruturado, com dados sobre autodeclaração de cor / raça. A educadora afirma que, por meio destes dados, pode compreender questões que considera importantes, como a origem social e territorial, autodeclaração racial, reincidência infracional, entre outras informações. 
A Fundação Casa conta com publicação específica sobre a temática racial (SILVA e SAÚDE, 2010), porém, conforme os relatos, esta não seria mais distribuída, nem disponibilizada online ${ }^{37}$. O material conta com instruções, sugestões e recomendações de temas e atividades para discussões e práticas na temática racial, além de indicações de filmes, músicas, e textos curtos sobre o tema.

As profissionais atuantes junto à Fundação Casa falam que muitos jovens não se declaram negros abertamente, alguns possuem outras terminologias de autoclassificação racial, sendo comum utilizarem termos jocosos, que a educadora afirma aceitar também, de forma a trabalhá-los, posteriormente, pois fazem sentido para aqueles jovens naquele momento e contexto. Conforme relata, há muitos que se autodeclaram "pardos", mesmo tendo a pele mais clara, o que parece, em sua perspectiva, se relacionar a uma compreensão sobre as questões raciais.

Em sua visão, jovens que estão há mais tempo no sistema de medida socioeducativa, ou que estão reincidentes na internação, têm maior consciência racial. Uma "socialização racial" (BARBOSA, 1987) pode acontecer a partir da medida socioeducativa (da internação, neste relato especificamente), diálogos e reflexões sobre a questão racial e sobre o autoconceito quanto à própria cor / raça acontecem a partir da internação, da ação policial, da investida do Poder Judiciário. Barbosa (1987) apresenta a socialização como um conjunto de elementos que ocorrem nos primeiros anos de vida, dada a partir de elementos socializadores, fornecidos em geral pelas famílias, num primeiro momento, e, ao longo do desenvolvimento, pelas demais instituições e relações. Conforme a autora, em famílias negras, a emergência de uma identidade negra

\footnotetext{
${ }^{37}$ A Fundação CASA tem desenvolvido uma forte parceria com grupos religiosos evangélicos, que desenvolvem atividades junto aos jovens nas unidades de internação. Especulamos que esta seria, possivelmente, um dos fatores motivadores para a retirada de circulação do material, uma vez que este apresenta referências às religiões afro-brasileiras.
} 
ocorre, geralmente, a partir de uma situação concreta, uma "experiência crítica", onde se revelam os valores morais das diferenças raciais, como a discriminação ou o preconceito. A partir dessa forma de socialização, jovens adultos negros reinterpretam suas relações sociais, e impõem uma nova avaliação a seus projetos.

É no encontro com outros jovens negros, implicados num sistema de exclusões e possibilitado a partir da infração, no vivenciar das cenas periféricas, e nas coincidências de violências e abordagens tipificadas e discriminatórias, que o jovem se percebe negro. Seguindo esta argumentação, deparamo-nos com a controversa afirmação de que, por meio dessas "experiências críticas", a Fundação Casa ou mesmo relações estabelecidas pelo tráfico serviriam a jovens negros como agências da socialização racial.

A autora Neuza Santos Sousa (1983), em sua obra "Tornar-se negro", trata como um exercício da autonomia "possuir um discurso sobre si mesmo". Sobre seu reconhecimento enquanto negra, a autora dirá se tratar de "viver a experiência de ter sido massacrada em sua identidade, confundida em suas perspectivas, submetida a exigências, compelida a expectativas alienadas" (p.18). Para a autora, o reconhecimento da negritude é um "vir a ser", passa pelo rompimento de um ideal de identidade branca, socialmente estabelecido, e posiciona o negro brasileiro numa tensão de ascensão social. 


\section{Capítulo 7. POLÍTICAS SOCIAIS, FAMÍLIAS E AFETOS}

[Entrevistada 4] - Eu fiquei pensando de quando a gente perde um menino, né? E o primeiro menino que eu perdi aqui, em situação de violência mesmo. Todos os que a gente perde é violência, mas ele foi assassinado. Ele foi assassinado por uma pessoa que era conhecida da família, que era um agente do Estado, ele tinha um envolvimento com a irmã desse cara, e o cara sempre prometia pra irmã que ia matar ele. Mas... Ele era um menino muito aventureiro, até nas conversas, sabe, destemido [...] ele era muito engraçado. Aí ele achava que nunca ia dar nada, ele não acreditava, e aí um dia, o cara armou uma emboscada e, realmente, matou ele dentro de um (comércio de) açaí, próximo de casa. [...] Não foi dito que foi ele, mas é claro que foi ele! Da forma que aconteceu e tudo... Aí, outra mãe que eu fiquei pensando... Porque ele era filho único, né? E ela se dedicou o tempo inteiro pra ele. Ela era uma mãe muito dedicada a ele. E tudo que ela fazia era em torno dele. E eu ficava pensando como que a vida ia andar depois disso... Eu acho que perder um filho já é difícil, e dessa forma. Eu lembro que a gente foi fazer uma visita e ela falou assim, "eu tô sofrendo, mas eu agradeço de não ser a mãe da pessoa que causou isso, eu estaria sofrendo muito mais". E o quanto você vai buscando curar sua dor com uma coisa dessas, né? Que eu acho que na verdade, o que ela queria mesmo é que o filho dela estivesse lá, não importa... [...] Você não quer perder um menino... Ele era adolescente ainda, não era nem jovem, tinha 16 anos. E perder o filho dessa forma, [...] foi uma execução. E aí, depois de muito tempo, acho que tem um ano mais ou menos, eu tentei voltar a falar com ela. Eu consegui falar só com a irmã [dela]. A irmã falou que ela não estava bem, que nunca mais foi a mesma, ela trabalhava, estudava, era bem ativa. Ela foi embora pro interior, tava depressiva, tava indo cuidar da família... E eu fiquei pensando nisso, o quanto o Estado é programado pra fazer isso com a gente, né? Se ele não adoece, ele mata ou encarcera.

A fala da profissional apresenta diversos elementos importantes, trata de uma relação que o serviço de medidas socioeducativas desenvolve com as famílias e com os jovens, para além do escopo de atuação institucional, de modo que esse vínculo se mantém mesmo após a perda do jovem pelo óbito. A profissional fala de um recorte geracional implícito, entre menino, adolescente e jovem. E também da sua identificação com a mãe, "você não quer perder o menino" - está falando pela mãe, falando também por si mesma, não deseja perder o menino que atende e com quem desenvolveu um vínculo afetivo, e fala, finalmente, por seus interlocutores, quando os convoca na segunda pessoa, "você". 
Neste tópico, tratamos das políticas sociais que buscam estratégias e ações de um Estado mais inclusivo. Este parte, porém, de uma contradição fundamental, que é seu caráter tardio: a "face afetiva" do Estado, que somente é revelada aos jovens e famílias moradores da periferia após encararem diversas facetas de punição e exclusão.

\section{Relações familiares, medida socioeducativa e a face afetiva do Estado}

As políticas sociais que fundamentam o Sistema de Medidas Socioeducativas, em todas suas esferas de gestão, e para as diferentes medidas específicas, têm como pano de fundo um preceito que resguarda seu cerne democrático: o direito à convivência familiar e comunitária. Isto é, um direito do jovem, latente na aplicação da medida socioeducativa, que resgata à defesa de Proteção Integral, prescrita pelo ECA, e o valor constitucional, posto que fundamenta-se na Constituição Federal de 1988, Artigo 227:

É dever da família, da sociedade e do Estado assegurar à criança, ao adolescente e ao jovem, com absoluta prioridade, o direito à vida, à saúde, à alimentação, à educação, ao lazer, à profissionalização, à cultura, à dignidade, ao respeito, à liberdade e à convivência familiar e comunitária, além de colocá-los a salvo de toda forma de negligência, discriminação, exploração, violência, crueldade e opressão (Constituição Federal de 1988, Art. 227) ${ }^{38}$.

O mesmo direito se apresenta no Artigo 4 do ECA, que transcreve quase que literalmente o texto da Constituição:

É dever da família, da comunidade, da sociedade em geral e do poder público assegurar, com absoluta prioridade, a efetivação dos direitos referentes à vida, à saúde, à alimentação, à educação, ao esporte, ao lazer, à profissionalização, à cultura, à dignidade, ao respeito, à liberdade e à convivência familiar e comunitária (Estatuto da Criança e do Adolescente, Art. 4. BRASIL. Lei Federal 8069, 1990).

Passado um longo período histórico onde soluções privativas de liberdade marcavam a conduta das instituições brasileiras, reafirmar tal direito parece relevante e

\footnotetext{
${ }^{38}$ Ênfase (em itálico) do pesquisador.
} 
premente. Com este parâmetro, objetiva-se preservar a unidade familiar, ainda que diante de contextos de vulnerabilidade sociais e econômicas. Pressupõe-se também que o jovem tem direito a usufruir de sua comunidade, de seu território, dos serviços públicos, que terá disponibilidade a todos seus direitos.

Por convivência familiar e comunitária, entende-se a possibilidade da criança permanecer no meio a que pertence. De preferência junto à sua família, ou seja, seus pais e/ou outros familiares. Ou, caso isso não seja possível, em outra família que a possa acolher. Assim, para os casos em que há necessidade das crianças serem afastadas provisoriamente de seu meio, qualquer que seja a forma de acolhimento possível, deve ser priorizada a reintegração ou reinserção familiar - mesmo que este acolhimento tenha que ser institucional (RIZZINI, 2007).

Na esfera distributiva de direitos, este cenário, entretanto, não se concretiza, especialmente, se tratando dos jovens vivendo em periferias. De acordo com o caráter de sua infracionalidade, o adolescente e jovem teria respaldado o direito de preservar sua convivência junto à família, junto a amigos, à comunidade a qual pertence, sem que necessariamente seja privado de liberdade recluso numa instituição. Contudo, o cenário não condiz com o que se apresenta para a maior parte dos jovens em situação de conflito com a lei.

É possível a reflexão que muitas das prerrogativas postuladas no ECA em famílias de classes média alta e alta são premissas básicas, necessárias; cuja necessidade de reafirmação somente faz sentido se tratando de crianças, adolescentes e jovens, a quem "ter direitos" nem sempre é um fato explícito, uma obviedade, ou seja, as camadas mais pobres da sociedade.

Liane de Paula (2004), em sua pesquisa "A família $e$ as medidas socioeducativas", fala sobre três movimentos das políticas para crianças e adolescentes nas instituições totais, que surgem no Brasil do século $\mathrm{XX}$, partindo dos discursos e refletindo em práticas institucionais: um primeiro que faz com que o Estado intervenha 
de modo institucionalizante, interna-se para evitar, prevenir a infração que se presume; a relação com a família passa por um severo controle e rigorosa e constante vigilância por meio dos agentes do Estado. Um segundo movimento cooptava as famílias na produção de relatórios e documentos que descreveriam os "menores" e suas famílias numa dinâmica de desestruturação culpabilizante, cabendo à internação um papel de "benefício" familiar, uma vez que seu papel supostamente orientaria e promoveria socialmente jovens e seus familiares; o modelo de encarceramento é compreendido aqui como uma "ressocialização". O terceiro movimento, mais recente, pautado pela perspectiva dos direitos humanos e da participação social, dialoga com os artigos apresentados na Constituição Federal de 1988 e com o ECA, a inter-relação entre Estado e famílias pobres, no âmbito das medidas socioeducativas, passa a recorrer a técnicas de ordem "corretivas", que substituiriam a estratégia carcerária, constitui-se, a partir dai, um eixo socializador como diretriz das estratégias por meio das medidas socioeducativas em meio aberto.

Isto ocorre porque, conforme destaca Sposati (2011), o movimento constitucional de 1988 promove uma nova perspectiva que orientará as políticas sociais, de modo que a proteção social seja "tratada como bem público e social do estatuto de uma sociedade para alcançar todos os seus membros". Isto é, havia, em tempo, uma compreensão para as políticas assistenciais que as direciona no contrato coletivo, uma responsabilidade entre o Estado e todas as camadas da sociedade, compartilhada e convencionada através de instrumentos legais específicos, que se legitimam em políticas públicas.

Pensando na realidade das medidas socioeducativas, a priorização das medidas em meio aberto sobre as estratégias de encarceramento, e, quando na ocorrência destas, 
a proximidade da unidade de cumprimento da internação com o território de origem deveriam ser pressupostos básicos da garantia do direito à convivência familiar e comunitária, possibilitando a visita de familiares e amigos, ou mesmo profissionais que acompanhavam o jovem em medida em meio aberto (não é incomum nos relatos dos profissionais a manutenção de algum contato com os jovens e suas famílias, mesmo depois de internação na Fundação Casa, fim da medida ou cárcere depois de adultos).

Infelizmente, os relatos dos profissionais tratam do cumprimento da medida de internação em regiões bastante remotas em comparação às regiões onde vivem, e das "medidas acumuladas", medidas sobre medidas, ou seja, o cumprimento de uma medida seguida por outras medidas, aumentando a penalização do jovem no sistema socioeducativo, e, consequentemente, reduzindo suas concepções da vida ao cumprimento de uma penalização; na prática, a redução da idade penal institucionalizada, embora extraoficial. Nas histórias que acompanhamos há também percursos de institucionalizações em diferentes instituições, como internações hospitalares de ordem psiquiátrica, e em SAICA, serviço que trata do acolhimento de crianças e adolescentes quando há ruptura ou destituição do vínculo com a família, movimentos asilares que formam "circuitos socioassistenciais-sanitários" (OLIVEIRA et.al., 2018).

O direito à convivência familiar e comunitária é na verdade parte de um contrato entre os diversos agentes e organismos da sociedade tendo em vista que crianças, adolescentes e jovens se desenvolvam em ambiente presumidamente adequado, seguro, onde existam os meios necessários à convivência e ao afeto, que preserve direitos, em vez de violá-los, que garanta condições de fortalecimento, em vez do agravamento de vulnerabilidades. Furtado et.al. (2016) destaca que há nos instrumentos legais e políticas 
públicas diversas definições sobre o que é família, contudo, o entendimento da noção familiar passa por sentidos ainda mais complexos.

Entretanto, a definição legal não supre a necessidade de se compreender a complexidade e riqueza dos vínculos familiares e comunitários que podem ser mobilizados nas diversas frentes de defesa dos direitos de crianças e adolescentes. Falar em família pressupõe pensar as diferenciações por classe também, uma vez que o entendimento de família para o pobre não é o mesmo para a classe média (FURTADO et.al, 2016: 134).

Haveria no sentido de "família" um pressuposto moral atrelado a redes, que se constituirão para além de relações de descendência, consanguinidade e afinidades (FREITAS et. al., 2011; FONSECA, 2005 e 2006), modelos que superam um suposto ideal da família heterossexual, branca e classe média. Nesta concepção, se "considera as redes formadas por vizinhos, parentes, amigos, como parte do contexto de proteção, o que daria à família melhores condições de enfrentar a vulnerabilidade e o risco social” (FURTADO et.al, 2016: 135). Família como redes, famílias extensas (FONSECA, 2005 e 2006). Sposati (2011) afirma que a capacidade protetiva da noção familiar se apresenta nas políticas sociais à medida que configura modelos não-autoritários de gestão, pensando que as famílias, em suas dinâmicas e disposições diversas, operam em parceria e ao mesmo tempo que a ação planejada do Estado. "Está em questão um novo campo de saber: o significado da capacidade protetiva da família, do âmbito dessa proteção e das fragilidades e riscos sociais a que a própria família e seus membros estão sujeitos" (SPOSATI, 2011: 19).

Nesse aspecto, um importante avanço das políticas de proteção social diz respeito à sua preocupação, sobretudo, no "como" protegem, mais do que em "quem" protege (Sposati, 2011). Como as famílias se organizam para lidar com questões de ordem social e com as situações de vulnerabilidades pode refletir em seus diferentes níveis de vulnerabilidade e protetividade, e isso tem maior relevância do que como se 
configuram essas famílias, se com ambos os genitores, monoparentais, homoafetivas ou heteroafetivas, se além ou invés dos genitores apresentam uma rede estendida de familiares e cuidadores, como avós, avôs, tias e tios, se se articulam com amigos, vizinhos e incluem outros níveis de parentesco e arranjos diversos.

Em pesquisa, o Ministério Público do Estado de São Paulo (2018), constata que os jovens em atendimento socioeducativo deste Estado participam de uma dinâmica familiar em muitos casos de monoparentalidade. $20 \%$ dos entrevistados vivem com a mãe e irmãos; $9,5 \%$, somente com a mãe; 6,3\%, com o pai e irmãos; 4,7\%, com mãe e padrasto; e 4,7\% já têm sua (seu) própria companheira(o). O número de arranjos familiares do tipo composto por mãe, pai e irmãos é 19\%, uma exceção, portanto, quando somadas as demais configurações familiares.

\section{Trabalho socioeducativo e vínculos sociais, ter com quem contar}

As políticas sociais, especialmente no campo da Assistência Social, falam com frequência no ordenamento do trabalho nas modalidades socioassistenciais e socioeducativas, este último passa por diversos programas e políticas, não somente aquelas voltadas à proteção social de jovens em contextos de conflito com a lei. Percebemos ainda que há no escopo dessas políticas pouca definição do que seria essa modalidade de trabalho, como se sua definição fosse dada como certa ou implícita.

Ainda que não se disponha dessa definição nas políticas, trata-se de um conceito marcado pelo direcionamento das práticas na perspectiva de participação da sociedade nas ações, serviços e equipamentos sociais, de modo que a parceria com coletivos, com organizações sociais, com as redes que se articulam nos territórios, e com as famílias seja fundamental para a consolidação dessa proposta denominada socioeducação. $\mathrm{O}$ 
conceito remete que há um trabalho que, para além da inclusão em políticas de garantias de direitos sociais, definido na noção de trabalho socioassistencial, há ações educativas que se associam com vistas a fortalecer sujeitos, famílias, grupos e comunidades específicas, contemplados por estas políticas.

Em publicação do Ministério do Desenvolvimento Social e Combate à Fome (2009a), Berenice Couto apresenta o conceito de segurança de convívio, inerente ao trabalho socioeducativo. Dá-se por meio de ações e serviços contínuos que garantam construção e fortalecimento de laços de pertencimento e vínculos sociais. "Fazendo com que os atendimentos possam transitar do pessoal ao social, estimulando indivíduos e famílias a se inserirem em redes sociais que fortaleçam o reconhecimento de pautas comuns e a luta em torno de direitos coletivos" (Ministério do Desenvolvimento Social e Combate à Fome, 2009a: 212).

Definir o trabalho socioeducativo no seio da noção de convívio seguro e pensar sua atuação no desenvolvimento de vínculos é compreender que as políticas não são sustentadas apenas de uma camada técnico-burocrática, mas que há conteúdos relacionais que devem ser vistos, incentivados e produzidos. Sposati (2011) apresenta uma bonita definição sobre os vínculos sociais:

A ideia de vínculos sociais associada à proteção social permite sintetizá-la na expressão "ter com que e com quem contar" face às agressões, fragilidades, aos riscos sociais e, mais do que isso, em ter segurança, ampliar o sentimento de certeza e de reconhecimento na construção da vida social. Com esta afirmação, pode-se concluir que para além das ofertas objetivas, como a presença de atenções públicas, os vínculos sociais compõem o potencial de proteção social. A condição de "poder contar com" significa grau de solidez de um vínculo. Não basta ter uma unidade de saúde em um território para sentir-se protegido caso não se possa contar com a presença (e o vínculo) com um médico, por exemplo. Os vínculos se estabelecem entre parentes, amigos, vizinhos, mas também, com agentes dos serviços gerando relações de certeza (SPOSATI, 2011: 07). 
Compreendemos que esta definição oferece de maneira contundente uma orientação à gestão e organização de políticas públicas em seu aspecto relacional, no que tange a seu papel frente às comunidades, famílias e indivíduos. Mensura a eficiência e eficácia das políticas e serviços numa dimensão qualitativa, de modo que "poder contar com" se torna critério discriminativo. Assim como a família, os amigos e os vizinhos, as políticas e serviços integram uma rede de referências protetivas que é singular para cada comunidade e território, além de para cada sujeito.

Entendemos aqui uma possibilidade de aproximação teórica com o campo de saber da saúde coletiva quando Merhy (2002) apresenta os conceitos de tecnologias aplicadas à produção de cuidado em saúde. Merhy compreende que as tecnologias são, não um "conjunto de máquinas", mas uma série de saberes e conhecimentos e relações que se implicam na organização da saúde, e têm resultado produtivo. Esta noção de tecnologias é definida pelo autor como, não somente equipamentos e máquinas, com os quais não se deve confundir este conceito, mas incluem-se "como tecnologia certos saberes que são constituídos para a produção de produtos singulares, e mesmo para organizar as ações humanas nos processos produtivos, até mesmo em sua dimensão inter-humana".

Ou seja, é no potencial produtivo, na dimensão da produção, que o autor define suas tecnologias $^{39}$ (Foucault, 2010). Especificando-as em três tipos, dada sua densidade instrumental: tecnologias duras, tecnologias leve-duras, e tecnologias leves. Duras são aquelas tecnologias cujos modos de intervenção requerem um aparato específico de

\footnotetext{
${ }^{39}$ A noção de tecnologias é amplamente usada por Foucault. De fato, Foucault (2010) muitas vezes utiliza tecnologia enquanto disciplina, de modo diferencial a técnica, como prática. Foucault também trata de uma "tecnologia da verdade" e de "tecnologias de poder", "a maneira como os fenômenos, as técnicas e os procedimentos de poder atuam nos níveis mais baixos; como estes procedimentos se deslocam, se expandem, se modificam; mas sobretudo como são investidos e anexados por fenômenos mais globais" (p. 184).
} 
equipamentos e maquinário, no sistema de saúde, pensamos nas máquinas de raio-x, nos laboratórios de exames, até mesmos os fichários onde se registram dados dos pacientes, Merhy compreende que o trabalho quando baseia-se somente neste nível tecnológico arrisca ser capturado pela "lógica do trabalho morto", expresso por uma dinâmica onde razão humana e intencionalidade humana não se impõem. Leve-duras são as tecnologias marcadas pelos conjuntos estruturados de saberes que compõem uma clínica: a medicina, a psicologia, o serviço social, a administração, formados por um conjunto de técnicas, métodos e processos que configuram sua produção de conhecimentos. Leves são as tecnologias de relações do tipo de "produção de vínculos", as técnicas de acolhimento, a promoção de autonomia e participação dos sujeitos. $\mathrm{O}$ autor trata do potencial produtivo destas últimas, especialmente, pensando uma lógica do "trabalho vivo", onde sujeitos e subjetividades se posicionam, se relacionam, provocam movimentos e mudanças que atualizam os processos de trabalho.

No esforço de estabelecer uma relação entre Merhy e Sposati, com a ressalva que se tratam de autores produzindo em campos de conhecimentos com suas especificidades próprias, pensamos a importância do trabalho vivo e da mobilização tecnológica aplicada ao sistema de medidas socioeducativas. Verificando as experiências em campo, o sistema de medidas socioeducativas em meio aberto tende a recorrer ao uso de tecnologias leves e leve-duras, dispondo potencialmente de melhores condições de produzir vínculos, especialmente se dirigindo sua produção na proteção dos direitos de convivência familiar e comunitária, na lógica produtora de vínculos sociais. Por outro lado, requisitando tecnologias duras, e consequentemente gerando mais custos, estaria o sistema de medidas socioeducativas que priva o jovem da liberdade, as unidades de internação, mobilizando grandes aparatos de vigilância e 
punição, composto por agentes e equipamentos de segurança pública e judiciais, comandando complexos de encarceramento. Isto posto, podemos separar o sistema de medidas socioeducativas por seus eixos produtivos, de um lado, projetos que implicam tecnologias de vínculo e cuidado, incluindo e garantindo direitos; de outro lado, tecnologias do cárcere ou das punições legitimadas.

Os profissionais relatam haver outros serviços de medidas em meio aberto onde “assinar o L.A.” parece ser a principal conduta pautada, ou seja, as atividades têm por finalidade atender condutas técnico-burocráticas, respondendo em conformidade à imposição judicial da medida, produzindo a partir da dureza tecnológica, portanto. E mesmo na Fundação Casa, é possível dizer que a produção de vínculos tem potencial de acontecimento, como relatam as colaboradoras de nossa pesquisa, cabendo a ressalva que o surgimento destes talvez se dê pela disponibilidade, que é também uma resistência, oferecida por alguns profissionais ou pelos internos entre si.

Assim, os sentidos que escapam, orientando para o vínculo ou para o burocrático, têm possibilidades bem mais amplas de ocorrência e de um conjunto aberto de determinações - é o devir de que nos fala Biehl (2008), "esforços individuais e coletivos de afrouxar e relativizar, na medida do possível, os marcadores e controles e violências estruturais, alcançando assim uma imanência, o poder do impessoal - uma vida" (p. 422). Cruz (2015), afirma que "narrativas diferentes também podem ser construídas" sobre as instituições que atendem a juventude, "mas fica a pergunta: neste caso, como foram concebidas a criança (os jovens, em nosso caso) e suas necessidades? Como foram concebidas as famílias e as instituições"? Entendemos, finalmente, a importância da discussão sobre os diferentes investimentos tecnológicos que se faz / e 
os que fazemos. Das diferentes localizações dos sujeitos, para onde apontam seus discursos, recursos, propostas, ações e estratégias?

\section{A primeira batida do Estado à porta - infracionar para incluir}

O espaço oferecido pelos serviços de meio aberto visitados oferta a proposta de preservação da segurança de convívio aos jovens, como garantia de seus direitos.

Porém, num conjunto operativo e organizacional do sistema de medidas socioeducativas, um dos impasses que os entrevistados frequentemente apontam é como garantir que adolescentes e jovens negros e moradores das periferias - aqueles que estejam ou não em conflitos judiciais - tenham acesso a seus direitos? Percebemos que a instituição de mecanismos legais oficiais, como o ECA e o Estatuto da Juventude, não somente serviu para reafirmar que adolescentes e jovens tenham direitos básicos, mas reafirmar isto enfaticamente às camadas mais pobres da sociedade, uma vez que postula premissas que são implícitas e bastante óbvias para as famílias de classes média-alta e alta da população.

Nesse sentido, o atendimento socioeducativo em meio aberto, em sua defesa do direito à convivência familiar e comunitária, implica a garantia de acesso ao jovem pobre, aqui taxado enquanto infrator, a recursos que em outras condições não teria. Passeios, atividades lúdicas e de lazer, discussões e atividades educativas, e, como percebemos para alguns casos, até mesmo estabelecer e manter um circuito relacional com uma pessoa ou um grupo de pessoas, com um espaço, com os profissionais que o acompanham e os coletivos. 
A fala a seguir faz apontamentos sobre essa condicionalidade do acesso aos direitos, que passa pela medida socioeducativa em meio aberto, e é identificada por todos os entrevistados da pesquisa:

[Entrevistada 9] - Na verdade, o ato infracional, ele é apenas a publicação do conflito, porque, anterior a isso, muitas violações já vêm acontecendo, meninos e meninas que são violados antes de nascer, essa é a grande questão. Então, quando acontece o ato infracional é que eles são vistos, são enxergados e começa-se a pensar em garantir direitos. Que garantia de direito é essa? Primeiro ele tem que ser punido pra ter os direitos garantidos! E é muito complicado pensar, quando se fala, "adolescente em conflito com a lei" ou é a lei em conflito com o adolescente? É uma coisa a se pensar também.

No diálogo reproduzido a seguir, os profissionais discutem esta relação entre a garantia de direitos estabelecida entre os jovens habitantes de regiões periféricas e o Estado:

[Entrevistada 14] - Às vezes esse menino, ele só chega ao Estado quando ele...

[Entrevistado 1] - Isso é outro paradoxo.

[Entrevistada 14] - Ele foi negado todos os direitos dele. Então às vezes ele só sabe o que é o poder do Estado, quando o Estado chega pra privar, pra punir.

[Entrevistado 3] - Pra prisão.

Durante este diálogo, chegamos ao entendimento junto aos entrevistados de que o Estado, a primeira vez que bateu na porta do jovem, foi pra prender, a primeira batida. Um dos entrevistados então menciona que o direito de ir e vir de um jovem na periferia está constantemente sob ameaça.

[Entrevistado 1] - Nós somos um serviço que abrimos as portas para acompanhantes, por exemplo, vem o adolescente que cumpre medida, o amigo dele pode entrar. Os amigos deles podem participar de atividades diversas aqui no serviço, não todas, mas podem participar. Então por exemplo, (quando) a gente tem um passeio externo, (o amigo do jovem) pode participar. Mas é um paradoxo muito grande saber que... Por exemplo, a gente foi pro Museu do Futebol -, saber que o menino só vai poder ir pro Museu do Futebol a partir do momento que ele infracionar. O menino pergunta isso também. A gente dá um Bilhete (Único) pra ele poder ir e voltar. 
Ele tem o transporte. Então, (quando o jovem) vem com um amigo, ele está recebendo bilhete pra ir e voltar. $\mathrm{O}$ amigo, que não tá assinando, fala, "tio, eu não ganho? por que eu não vou ganhar?" É um paradoxo gigantesco, o menino precisa cometer um ato [infracional] pra ele ter o direito de ir e vir.

$\mathrm{O}$ acesso a serviços e equipamentos de cultura e lazer aparece em outros momentos quase como um "privilégio", que precisa ser intermediado institucionalmente. Do contrário, não é próprio ao jovem da periferia, não está a seu alcance e pertencimento.

[Entrevistado 3] - Mas sei lá, uma sessão de cinema. Uma coisa que pra gente é hiper básica, ir no cinema. Mas eles [só] vão quando a gente [serviço MSE] consegue fazer alguma coisa.

[Entrevistada 6] - O dia que a gente foi no cinema ano passado, eles causaram. Cinema ano passado foi bombástico!

[Entrevistada 14] - Até porque, se ele entra num shopping, ele vai ser visto como ameaça. Então tem lugares pra ele que são de "nãopertencimento", "eu não pertenço a esse lugar, porque as pessoas de lá estão o tempo todo me dizendo que não é lugar pra mim".

[Entrevistada 6] - E com olhares!

[Entrevistada 14] - Não é lugar pra mim, o shopping, o museu não é lugar pra mim, até mesmo uma praça que tem, ele acha que não é lugar pra ele.

[O entrevistador questiona se isto ocorre em decorrência das rondas policiais na praça pública]

[Entrevistada 13] - Principalmente se eles estão em grupos.

O cotidiano das periferias é marcado por episódios que por si mesmos violam o direito de seus moradores, jovens ou não, à participação comunitária, e restringem muitas de suas liberdades enquanto indivíduos e comunidades. A presença de mecanismos ostensivos, como as rondas das polícias, seu caráter de ameaça, as situações de agressão e violência, contra outros jovens, entre moradores, em diversas conjunturas situacionais, praticadas por uma diversa gama de agentes. E as mortes. As mortes estão presentes no cotidiano das favelas, como disse um dos entrevistados, 
relatando a contemplação de cenas de morte frequente, que sempre lhe deixava diversos questionamentos.

\section{As mães, os pais, as famílias}

[Entrevistada 15] - Acho que pra quem quer atuar ou até mesmo pesquisar, acho que tem que se esvaziar. Tem que vir com o cálice vazio. Deixar sua moral, seus costumes, seus ideais, tem que deixar tudo lá fora. Tem que vir nulo assim, sabe? Acho que por uma questão, pra respeitar as famílias, porque a família tem uma história, tem uma vivência, tem todo... Então você tem que se esvaziar por respeito àquela família. A forma como você vai lidar com a história, que não são "problemas", como a gente já ouviu, não são números, como dado aí pelo Estado, são pessoas. Estão vivas, têm histórias, ela chegou aqui num momento, mas até ela chegar aqui tem toda uma trajetória de vida. Então, acho que é isso, se esvaziar, quando chegar aqui.

[É um pouco o que a Entrevistada 4 tinha nos dito, que: "seus valores só com seus filhos funcionam"]...

[Entrevistada 15] - Com seus filhos! E às vezes nem funciona com nossos filhos, nem com nossos não funciona (risos). Então a gente tem que deixar isso pra lá.

A fala extraída do relato da profissional antecipa algumas questões: Uma delas, sobre os atravessamentos morais pelos quais o campo da medida socioeducativa passa. Ainda, uma necessidade que se impõe da compreensão dos sujeitos para além de suas passagens infracionais. Também nos relata que há arranjos familiares que ultrapassam os modelos compreendidos como "padrões", e os trabalhadores das políticas sociais lidam com esses diferentes arranjos, mais do que isso, parecem participar de alguma forma buscando também seu lugar nesses arranjos. Finalmente, chama também a atenção para as políticas de narratividade que ora resgatamos, mais que "problemas de pesquisa", "estudos de caso", ou opções que atendam a um regime de produção de verdade, seja nos dispositivos do Estado, (como "números", ou "pra quem quer atuar"), seja na produção acadêmica, (como "problemas", ou "pra quem quer pesquisar"), 
tratamos com histórias de vida que ultrapassam o escopo de nossos discursos. Conforme a proposta de Passos e Benevides (2009), a expressão de conhecimento que fazemos não apenas como "um problema teórico, mas um problema político".

As histórias que seguem são produzidas a partir do trabalho das equipes que colaboraram na pesquisa junto às famílias. Para além do previsto nas políticas socioassistenciais, representam também os vínculos que esses profissionais e equipes desenvolvem e o desempenho de um papel nos diferentes arranjos e organizações familiares. A antropóloga Claudia Fonseca (2005) apresenta uma discussão sobre o conceito de famílias e trata de possibilidades de intervenção no trabalho com famílias a partir dos "modos de vida", isto é, compreender que as demandas apresentadas por cada família aos serviços do Estado variam em conformidade com suas condições concretas de vida, suas práticas, suas crenças, suas formas de se organizar. Na intensa negociação entre famílias e Estado há uma tendência deste em “(re)privatizar” questões políticas e sociais ao âmbito familiar (SCHUCH, 2014, FONSECA, 2005). Fonseca percebe os trabalhadores que representam o Estado em meio a essa negociação constante, e propõe que a comprensão / intervenção pense os modos de vida como fenômenos de origem em circunstâncias sociais, econômicas e políticas, "que dê prova da criatividade de indivíduos agindo em sociedade" (p. 58).

As histórias falam sobre um trabalho desenvolvido junto a mães, cuidadoras e avós.

[Entrevistada 9] É importante até trazer, né? A importância dessa força feminina, né? Dessas mulheres, da presença delas, né? Porque são elas que tão nos presídios, que tão na Fundação Casa, que tão nos serviços de medida. É isso! Isso que a minha colega [Entrevistada 4, cujo relato segue transcrito no inicio do presente Capítulo] trouxe é uma verdade, quem compõem os grupos aqui são as mulheres, quem vai pras trincheiras são elas! São as mulheres, são as mães, são as avós, são essas mulheres! 
Mas também de questionamentos, de afetos, dissabores, do sentimento de impotência diante de um cenário de poucos recursos interventivos frente a graves questões colocadas pelas dinâmicas da sociedade e pelo Estado. Sobre a recusa de redução do trabalho aos mecanismos burocráticos, sobre o afeto e identificação com os sujeitos:

[Entrevistada 4] Porque ninguém que vive na periferia é saudável, gente! Não tem como você ser saudável e morando na periferia e tendo filhos, né? [A profissional é também moradora da região]. Você está sempre pensando, o seu psicológico não é o mesmo, você vive a vida, mas você não é saudável. Você tá pensando na violência constantemente. [No risco...]... No risco que você tá, ou no seu irmão, ou no menino no serviço...

Sobre interpelações e confrontamentos, questionamentos e autoquestionamentos. Sobre a possibilidade de lidar com faltas, em diversas ordens. Sobre a figura paterna que se apresenta e, tal qual o Estado, pode ser marcada por uma presença mais ameaçadora que afetuosa, pela ambiguidade da severidade que se impõe frente à expectativa de afeto. Ora como um paradigma a ser ou não seguido, outrora se deslocando para outras construções afetivas, modificando os papéis esperados sobre paternidade e filiação.

Filhos que são também pais e mães que são também filhas.

Acompanhamos a proposta do antropólogo João Biehl, quando este nos interpela: "Cabe a nós achar maneiras de criar com os nossos sujeitos e a partir deles novas figuras do pensamento", e nos desafia a "contar histórias com devires humanos". Seguindo este intento, as mães, pais, os meninos, e as meninas, os primos, os vizinhos, todos os personagens que são contados nessas histórias (e até um que é, também, contador) falam, não apenas da execução de políticas sociais, como de relações e devires.

Algumas categorias êmicas surgem neste exercício da contação de histórias, como a "casa dos dez" e a "casa dos vinte", termos comumente utilizados por 
profissionais que desenvolvem trabalhos territoriais no âmbito das políticas sociais, não somente profissionais do SMSE/MA, como agentes redutores de danos, agentes comunitários de saúde, entre outros, diz respeito a moradias, geralmente, pequenas em regiões de periferia ou ocupações irregulares, habitadas por famílias numerosas. Em publicação do Ministério da Saúde (2013), no Caderno de Atenção Básica n. ${ }^{\circ}$ 34, há uma descrição de uma dessas casas.

A "conversa de 18 " é outra construção de sentido, referente ao trabalho no sistema socioeducativo em meio aberto, diz respeito a uma conversa entre os profissionais do SMSE/MA com os jovens perto ou depois de completarem 18 anos, explicando as implicações de possíveis infrações à lei, que poderão resultar, daí pra frente, não mais em medidas socioeducativas, mas no aprisionamento.

\section{A história de Logun}

Logun, menino negro, 16 anos no começo desta narrativa, ou seja, quando nossa interlocutora o conheceu. "Era um menino muito doce, devia ser (filho do orixá) de Oxum ou de Logun" ... Nos conta a profissional, que doravante chamaremos de Oxum, que o conhecera nas atividades educativas realizadas na Fundação Casa, quando Logun cumpria medida de internação.

A mãe de Logun já era falecida e este fora criado por seu pai. Segundo o relato da educadora, Logun tinha laços com esse pai, porém, quando o pai entrou em um segundo casamento e formou uma nova família, começaram a ter conflitos constantes.

Cumpriu medida na Fundação Casa, e, ao sair, procurou por Oxum nas redes sociais para restabelecerem contato. Ao fim da medida de internação, Logun passou a viver com seu pai, madrasta e irmãos. 
Com as dificuldades da convivência, mudou-se e passou a morar com a avó.

Posteriormente, estaria morando sozinho.

Logun, vivendo por conta própria, queria jogar videogame, jogar futebol. Ser mais um jovem.

Em suas conversas com Oxum, dizia que não queria voltar à prática infracional.

Logo estava namorando. Logo sua namorada ficou grávida.

Tiveram um filho, passaram a morar juntos.

Logun logo tinha mais de 18 anos.

Estava traficando. Estava envolvido. E dizia a Oxum que queria sair "dessa vida".

Finalmente, a última notícia que teve é que havia sido preso. Por tráfico.

Oxum entende que sua história ilustra a necessidade de exercer um papel muitas vezes difícil numa família. Ser o filho. Seu caso acompanha o desenvolvimento de um papel de filho que não se consolida, e em inconclusos ciclos sucessivos da vida, se torna pai. Logun, se teve juventude, a teve por poucos dias, a perdera internado na Fundação Casa e depois na prisão. Tampouco dispunha de um lugar pra ser jovem e estar "em casa". Como pai tinha outro status social. O de provedor. Exercido a partir dos mecanismos geradores de renda que estavam ao seu acesso e que lhe eram conhecidos. Mas que eram sabidamente ilícitos - envolvido.

"Ter uma juventude" é a concepção que reproduzimos da fala de Oxum, no entanto recorremos ao texto de Maria Cristina Vicentim (2012), esta autora desenvolve o conceito de "descriançável", algo que passa também pela "adultização", isto é, imposição precoce de papeis adultos, "no panorama das relações contemporâneas quando estas produzem um empobrecimento ou mesmo um sufocamento dos processos 
de abertura, acolhimento e invenção de territórios com as crianças e adolescentes" (p. 31). Portanto, ainda que admitamos linhas de fuga e possibilidades para se "ser jovem" em ambientes institucionalizados, como a Fundação Casa, entendemos que casos como o de Logun habitam o descriançável, terreno empobrecido pela falta ou necessidade provocadas pela coação.

"Eu não quero voltar a fazer essas coisas". Não seria a única vez que ouviríamos, nos relatos em campo, esse desejo. Neste momento, o lugar do educador aparece como um vínculo referencial, não somente afetivo, mas com um conjunto de expectativas relacionadas aos projetos, possibilidades e suposições da vida nãoinfracional. Oxum era a interlocutora deste desejo, ao mesmo tempo, mãe e esperança. Mãe, porque era uma figura retirada da história afetiva de Logun, e talvez de suas crenças e sentidos de investimentos particulares. Mãe, porque Logun "sentia falta de pai”, “queria encontrar esse pai”, nas palavras de Oxum, e só o encontra quando Logun, ele mesmo, se investe na paternidade. Esperança, porque a prática infracional, a despeito de sua incidência, vista então da perspectiva da necessidade, não lhe cabia mais, naquele momento, o sentido exclusivo do desejo.

\section{A história dos primos}

A entrevistada, que aqui chamaremos de Ewá, conta que era responsável pelo atendimento de dois jovens que tinham um confuso grau de parentesco. "É enrolado, eu nem sei explicar, um é adotivo e ele é tio de outro. E não se sabe direito de que família que é, se é da adotiva, se é sanguínea, é uma confusão. Mas eles são parentes, se tratam como parentes". Têm respectivamente 14 e 16, Damião e Cosme. 
Em uma partida de futebol, se desentendem. O mais novo chega ao serviço de medida socioeducativa, conta à técnica o que aconteceu. "Eu briguei com Cosme, jogando bola. Eu vou matar ele". Ao ouvir isso, a profissional o repreende, "é assim que a gente resolve os problemas? Matando? É assim?”.

Os demais profissionais comentam que essa naturalidade parece relacionada à forma como entendem que a sociedade encaminha seus conflitos. Na favela, a morte se apresenta com frequência ao jovem, seja por meio de informações, das mídias, redes sociais, das conversas, comentários e boatos de rua, seja corporificada, real, pelo fim que tivera um estranho, algum conhecido, amigo ou parente, que, em dado momento, a vida se desnuda diante de seus olhos (Agamben, 2007).

"Eu não quero saber de você com confusão com ele. Vocês vão fazer as pazes, eu quero que vocês se resolvam"... Ewá não ofereceu um direcionamento, nem mesmo Damião lhe contara mais sobre seus planos... No outro atendimento, - conta, eles chegam juntos, "a gente fez as pazes". "Que bom! Não é assim que a gente resolve as coisas" - novamente adverte.

Sua participação enquanto adulta e enquanto referência parece ter resultado numa outra estratégia de resolução de conflitos. E continua seu relato, - "às vezes eles fazem isso porque tão vendo toda a sociedade que resolve as coisas assim, matando, tirando a vida. E a gente tem que também puxar essas reflexões. É assim que a gente resolve os problemas"? No campo das possibilidades, ações extremas muitas vezes se destacam, ofuscando as demais opções. A técnica comenta que, muitas vezes, as privações de possibilidades se associam a privações no campo da reflexão. “Às vezes na menor briga que o menino tem, ele chega com esses discursos (de morte)", completa, “que pensa na possibilidade, se vai fazer ou não, a gente nem tem como saber". 


\section{História da figura de um pai}

Interfaces com questões de gênero foram apontadas por muitos dos técnicos como um desafio em sua atuação, "a sociedade é machista, e não tem uma formação pra construir um tipo de homem, ser masculino, de outra forma". Ainda nesse sentido, outro profissional, que aqui chamaremos de Dan, replica, "Acaba sendo muito [de] replicar o que eles vivem. Então, tá lá criancinha, vê o pai sair pra trabalhar como pedreiro, volta bêbado e bate na mãe. Pra ele é natural. É o código que ele aprende".

Essas questões são observadas pelos técnicos nas vivências afetivas e relacionamentos dos meninos atendidos. A comparação feita nos relatos é com uma transmissão de valores machistas de modo intergeracional, não ocorrendo de modo “consciente", como afirmam, sendo, porém, reproduzida no cotidiano. Assim, "até ele criar essa consciência crítica, que ele pode ser de outra forma, ele pode ter outro tipo de relação com a sua companheira, com a sua namorada, é todo um processo. Então acaba que acontecem falas machistas, atitudes machistas".

Opanijé era um dos adolescentes em atendimento em meio aberto, Dan era seu técnico de referência, e relata o seguinte diálogo: "engravidei uma moça, vou meter o pé", disse o jovem em tom jocoso. "Pô, cara, como você vai falar uma coisa dessa? A figura de um pai é importante pra criança. Você sabe qual é o papel de pai? Você acha que pra você faz falta um pai na vida”?

Dan sabia de seu histórico familiar, criado em um lar monoparental, "por mãe solteira", assim como muitos outros jovens negros da periferia. Opanijé tomou um tempo de reflexão, seu pai e sua mãe não vivem juntos, e respondeu: "Pô, meu pai fez falta na minha vida"... Até então, conforme a explicação do técnico, Opanijé não se dava conta das relações machistas que se apresentavam em seu próprio histórico 
familiar, "uma coisa que você fala naturalmente, mas quando você pensa em você, o negócio pega, o negócio aperta" - define o profissional.

\section{História da família do Pé Torto}

O técnico Dan relata de seus primeiros atendimentos, pouco tempo desde que iniciara suas atividades naquele SMSE/MA. O jovem Ossaim cumpria medida por tráfico. Vivia numa "casa dos dez", alcunha pela qual são conhecidas pelos trabalhadores sociais as moradias ocupadas por dez ou mais membros da mesma família. "A família estava em condição muito vulnerável. Eram dez pessoas numa casa, sem banheiro, um quarto, sem renda, sem nada". O profissional segue descrevendo as condições de vida dessa família, que fora por ele atendida, além de ter realizado visitas ao domicílio, "não tinha acesso a equipamento de saúde, não tinha acesso a saneamento básico, morava em terreno de ocupação, vulnerabilidade extrema"!

Ossaim tinha ainda um irmão mais novo com uma deficiência no pé, este será aqui chamado de Aroni. Os técnicos foram contando sobre esta família, que alegava ter tido problemas no atendimento das equipes de saúde da família, pois viviam em um terreno de ocupações, onde os agentes comunitários de saúde não passavam, "eles tinham dificuldade de acesso porque era um terreno de ocupação. Então teoricamente, ela teria que ir até a UBS"... O entrevistador não questionou aos entrevistados se tal dificuldade de acesso era dos agentes comunitários para a família, ou da família para a Unidade de Saúde. Provavelmente, ambas as hipóteses... "A gente até perguntou sobre encaminhamento médico, se já havia feito algum tratamento de saúde para o irmão mais novo. Aí ela (a mãe) falou uma frase que me chocou muito", relata Dandalunda, outra 
técnica que também estava presente. "Se você for lá na UBS, eles me conhecem, é a mãe do menino do pé torto. É só falar que é a mãe do menino do pé torto”.

Dada à situação de irregularidade de moradia, mãe e padrasto dessa família, então, respondiam processos judiciais. "E o menino", - prossegue contando Dan, que iniciara a história, "depois ele parou de vir, foi um descumprimento [da medida]. Voltou pra Justiça, a gente não tinha mais acesso". O entrevistador questiona se Ossaim, em dado momento, traficava para tentar manter a família. "Em algum momento, ele tentou", afirma Dandalunda. "Acho que não é nem sustentar a casa", - contesta seu colega, "acho que na situação que eles estavam, de contexto de vida, cada um ia fazer alguma coisa pra tentar trazer comida (pra casa)".

O serviço de medida socioeducativa em meio aberto, inscrito na rede de proteção social especial por meio dos CREAS, pode incluir as famílias para o recebimento de cestas básicas mediante avaliação social e atendimento a critérios específicos. "É uma coisa pequena uma cesta básica, ainda mais da Assistência (SMADS), que é pequenininha. Mas como faz diferença! E a mãe dele vindo aqui pegar duas cestas básicas, sabe? Eram coisas que te sensibilizavam no sentido de vulnerabilidade"...

A história da família do Pé Torto afetou este profissional ao fazê-lo conciliar difíceis decisões, constatando paradoxos inerentes ao trabalho socioeducativo. Dada sua situação infracional, aquela família teve acesso a um direito (receber cestas básicas). Justiça e Saúde rodeavam aquela família, pela ausência ou pela presença punitiva. Na esfera produtiva da vida, cada sujeito e sujeita parecia buscar uma possibilidade à sua maneira e a seu alcance, de modo que a iniciativa individual substituía o papel do Estado, buscando sustento ou moradia. Condições sociais complexas e paradoxos que faziam o entrevistado se questionar: "E na hora de se colocar no lugar do outro, você 
fala, caraca, será que a atitude dele tá tão errada assim? O que eu vou tentar fazer pra tirar ele dessa atitude (o tráfico)? E se eu tirar ele dessa atitude, o que vai acontecer com a família?".

Entre tantas ambiguidades, Dan conclui que, de sua perspectiva a respeito da situação relatada, "o maior paradoxo do nosso trabalho é que eu não pude fazer nada... O menino voltou pra Justiça... Então você fica, poxa, será que eu poderia ter feito mais?... Esses casos são meio apertados nesse sentido".

\section{A história do contador de histórias}

A entrevistada Ewá começa a descrever o caso de um jovem a quem apelidou de "meu contador de histórias", devido às várias "histórias" que ele conta semanalmente, alegando motivos para não comparecer ao atendimento da medida socioeducativa. “Toda semana, ele chega e me conta uma história. Eu fico, meu Deus, qual a parte que é verdade dessa história que ele tá me contando, sabe?’...

Vunji, então com 14 anos, filho de uma lavadeira - a informação da profissão de sua mãe nos produzira um estranhamento. A mulher pega roupa dos vizinhos para lavar, uma profissão em desuso, como destaca a entrevistada, que por vezes a deixa sem ofertas de trabalho. Atendidos pelo Programa Bolsa Família, Ewá informa que a renda mensal familiar é de cerca de 70 reais ${ }^{40}$. Vivendo no Fundão do Jardim Ângela, “depois da ponte", numa região não asfaltada, seguindo por uma estrada de terra às margens da represa Guarapiranga. De forma que o serviço de medida não conseguiu concluir a visita domiciliar.

Em dado momento, Vunji conta à técnica de referência que está traficando. Num momento posterior, afirma não estar mais morando com sua mãe, que teria se mudado

\footnotetext{
${ }^{40}$ No período da entrevista, o valor era de 85 reais, reajustado para 89 reais, a partir de julho de 2018 .
} 
para o Piaui... E com mais algum tempo, o garoto deixa de comparecer e de entrar em contato...

É prática da medida socioeducativa de liberdade assistida o comparecimento aos serviços para atendimento junto aos profissionais de referência, a frequência é determinada pelo Poder Judiciário na imposição da medida. Após um mês de faltas, o serviço encaminha ao Poder Judiciário a informação do descumprimento da medida. Neste caso, a profissional se viu angustiada, para além das dificuldades de acesso à região onde vivia, não tinha o contato telefônico ou o novo endereço de Vunji.

Pouco tempo antes de um mês de faltas, Vunji retorna ao serviço, dizendo que está morando com seu pai agora.

Conta que voltou ao tráfico, o que motivou o distanciamento de sua mãe e sua mudança de Estado. Sua mãe o teria feito prometer parar de traficar, e ele não cumprira. Novamente, a profissional se vê diante de um posicionamento complexo. Como dirá que ele não deve traficar? Devido à sua idade, ao local onde vive, são difíceis as circunstâncias de empregabilidade. Devido às suas condições de vida, à falta de renda familiar, o tráfico emerge como mais uma solução informal de empregabilidade local.

Não somente Vunji, o “contador de história”, como também Ewá, atuam nas políticas de narratividade (Passos e Benevides, 2009), para além de um regime de produção de verdadeiro e exclusão do falso, "não mais pensada exclusivamente a partir de um centro do poder" - a medida imposta judicialmente, o trabalho de Ewá em função do Estado, "a política (de narratividade) se faz também em arranjos locais, por microrrelações” (p. 151). Vunji resiste nos contornos situacionais que faz, conta histórias para se adaptar à dinâmica da regulação do Estado, por sua vez, Ewá, enquanto 
recolhe os fragmentos das histórias contadas por Vunji, busca soluções para além das saídas institucionais, tentando preservar o jovem das consequências destas.

Ainda assim, este vínculo desenvolvido junto à profissional muitas vezes é posto à prova, pelo jovem e pelas condições concretas de atuação. Relata que naquela semana (da entrevista) ele chegou: "Eu faltei porque eu tô trabalhando com meu pai" ... Mas há uma incerteza entre suas histórias, quais são verdadeiras? Qual o caminho para se desenvolver o trabalho socioeducativo junto à família? "Eu pedi, dei um papelzinho, 'pede alguém da sua família pra vir falar comigo'. Até pra conversar com a família sobre isso!... Mas eu, até agora, não consigo". Como retirar da informalidade do tráfico e garantir acesso à renda de maneira formal e preservando seus direitos?

\section{História de Aganju e as figuras de autoridade}

Aganju cumpria a PSC - Prestação de Serviços à Comunidade, como medida socioeducativa. De personalidade temperamental, descrito pela técnica Ewá como um jovem que "tem conflitos de poder, tem conflito com o pai, e aí quase todas as relações de poder, é como se ele tivesse vendo a figura do pai, e ele briga".

A profissional tentou manter contato com uma Unidade Básica de Saúde da região e indicar ao jovem que cumprisse a PSC na mesma. Porém, Aganju é descrito como quem "não consegue lidar com a relação com o gerente, com o chefe, com aquele cumprimento daquela ação". Dessa forma, não consegue cumprir por muito tempo a medida socioeducativa na UBS.

Apesar disso, a profissional percebe nele outro aspecto, seu desejo pelo trabalho, seguido pela desmotivação em decorrência dessa dificuldade de adaptação com base nas 
experiências que teve. A profissional fala, "vamos fazer seu currículo, pra você tentar conseguir um emprego". "Quem que vai dar emprego pra mim? Eu não consigo, não" ...

Ela destaca a importância de uma conversa que teve com ele, e que é comum os técnicos terem com os demais jovens no serviço de medidas. Trata-se da "conversa de 18”. Aganju, agora com 18 anos, inicialmente se apresentava ao serviço como alguém que passava por muitas dificuldades financeiras, além das dificuldades familiares mencionadas junto ao pai. A profissional relata que ele vinha para a PSC usando um tênis rosa, provavelmente de sua mãe. E se envergonhava, "eu não tenho tênis pra ir pra prestação de serviços à comunidade" ... Agora, percebendo a maneira como tem se apresentado, ela desconfia que o mesmo tenha voltado ao tráfico, um campo trabalhista onde as figuras de autoridade são mais difusas, onde talvez ele também possa buscar afirmação numa posição de liderança. Se havia as dificuldades de adaptação às rotinas e processos de trabalho no mercado formal, a busca pela ilegalidade parece-lhe uma opção. Conforme Feltran (2008) descreve, há nas regiões periféricas uma disputa constante de espaço por legitimidade, que ocorre num confronto entre os sentidos de "trabalhador" e "bandido".

Pensamos a história de Aganju, por meio de suas possibilidades de resistência, inserido num contexto institucionalizante, e estando frequentemente "sob determinação", sua insubmissão ressalta o caráter de controle e punição do sistema que lhe submete e seus modos de ofertar oposição.

A técnica relata seu receio perante essa estratégia, diz que começa a sofrer, porque sabe que o jovem não voltará mais para o serviço, caso seja novamente detido. Não é que o jovem não seja responsabilizado enquanto menor, ela diz, mas depois dos 
18 é mais difícil. Ao que outro profissional completa: "depois dos 18 não tem ressocialização".

\section{A história de Onira, a mãe-filha}

Dos 120 jovens inscritos no serviço, havia seis meninas na época da pesquisa. Poucos casos, mas, segundo Dandalunda, uma das profissionais do SMSE, os poucos eram "bombásticos", "muito complexos".

A técnica que acompanha sua medida conta que Onira chegou aos 16 anos naquele serviço, na época estava grávida de seu segundo filho. Perdeu a guarda de seu primeiro filho ao ser institucionalizada na Fundação Casa, e a criança ficou sob cuidados da família paterna. Seu segundo filho contava com 04 meses à época do relato. Passam por "extrema necessidade", conta a profissional, demandas "de comida até moradia".

Onira vive com seu atual companheiro, um padrão de relacionamento descrito pela técnica como "conflituoso", em que o tom comunicativo se dá por meio de gritos um com o outro. Conta que o casal, em uma das ocasiões chamou a atenção da equipe, que pensou que estavam discutindo, mas "só tavam jogando dama, a gente pensou que eles tavam se matando".

Onira foi diagnosticada com sífilis durante a gestação e, no momento do parto, "transmitiu pra criança" (sic). A profissional da medida socioeducativa afirma ter tido conversas com a equipe de saúde e desconfia de possíveis negligências da Unidade Básica de Saúde.

Conforme Boletim Epidemiológico da Secretaria Nacional de Vigilância em Saúde (2017), dedicado ao tema da Sífilis, tem havido, nos últimos anos, grande aumento dos casos de sífilis em gestantes, congênita e adquirida. Tendência mais 
significativa a partir de 2011; somente no Estado de São Paulo, houve um aumento de até $800 \%$ das notificações de novas infecções no período entre 2011 e 2016. Também a partir de 2011, houve tendência ao aumento de casos em jovens gestantes na faixa etária entre 15 a 19 anos. O tratamento para esta infecção sexualmente transmissível é feito a partir da administração de medicamentos à base de penicilina benzatina, matéria prima em desabastecimento no mesmo período (SECRETARIA NACIONAL DE VIGILÂNCIA EM SAÚDE, 2017), agravando a ocorrência das novas infecções. O tratamento considerado adequado para gestantes infectadas por sífilis é o "tratamento completo para estágio clínico da sífilis com penicilina benzatina, e iniciado até 30 dias antes do parto. Gestantes que não se enquadrarem nesses critérios serão consideradas como tratadas de forma não adequada" (Id., 2017).

"Acho que talvez no pré-natal não houve esse tratamento (para a sífilis) que deveria ocorrer. Mas enfim, bem complicado. O bebê nasceu, teve que tomar sei lá eu quantas (injeções de) Benzetaci ${ }^{41} l$ '. A profissional descreve a situação como uma "ausência generalizada do Estado". Ainda, o bebê apresenta um agravo dermatológico, tem umas manchas na pele. E Onira também apresentava um cisto na garganta então não tratado.

[Dandaluda]- Ela pede no ônibus. Infelizmente, tem feito isso. Dentro do transporte coletivo. Ela pede. E assim, a gente percebe. Percepção assim, você não tem nada sólido. Ela nem quer levar, mas com quem ela vai deixar (a criança)? O marido sai pra vender no ônibus, ela tem que sair pra pedir. Ponto. Com quem vai ficar a criança? A mãe dela se nega. E ela vê a situação apertar [é precária]. A única alternativa que ela tem é sair de casa (para pedir)... Ou ela fica em casa. Tudo bem, ela pode optar por essa alternativa, mas ela fica sem ter dinheiro pra pagar o aluguel.

O serviço conseguiu junto ao CREAS garantir cestas básicas para Onira. Porém sua inscrição no Programa Bolsa Família não pode ser concluída. Os profissionais

\footnotetext{
${ }^{41}$ Antibiótico que contem penicilina benzatina.
} 
explicam que a mãe de Onira já tem essa inscrição no Programa, "a mãe fez o cadastro e a família (materna) recebe. A partir do momento que ela receber, a mãe não vai receber mais". Mãe e filha têm uma relação de conflitos, "a mãe não quer nem saber" ...

"Ela não pode desvincular (a inscrição da mãe no PBF), porque é menor de idade. E não pode pedir outro cadastro, porque dá cruzamento de dados”.

A equipe descreve a última visita domiciliar realizada, onde perguntam a Onira sobre seu filho mais velho, "Ah a gente foi visitar, tá com minha ex-sogra". Onira visitara o filho antes do Natal e, no mês de abril, os profissionais a questionaram sobre sua intenção de voltar a ver o filho. "Sim, vou (voltar a visitá-lo), mas não posso voltar agora, porque eu fui e ele me pediu um carrinho. E eu não vou voltar lá sem o carrinho".

\section{A história do processo kafkiano}

A situação de conflito com a lei (principalmente quando resulta na internação) de um jovem pode ter consideráveis efeitos nas dinâmicas familiares. "Isso é uma das coisas que acontece. Que a família ou extremamente acolhe, ou é aquela que fala assim, 'cansei, não dá mais, só vou até aqui"', nos dirá Zazi, um dos profissionais entrevistados antes desta história ser narrada por sua colega.

Ewá, a narradora da história, me conta que é comum em muitos dos casos, que o adolescente encaminhado para cumprir medida em meio aberto não saiba qual ato infracional de fato cometeu. Confuso com a obrigação do cumprimento da medida, muitas vezes encaminhado por outros órgãos do sistema judiciário, passando por abordagens policiais intimidadoras, longa burocracia, e a convivência com soluções institucionais que resumem suas trajetórias por longos anos. "O adolescente chega aqui 
e ele não sabe por que tá aqui, ele não sabe qual foi o ato infracional dele. Você tem noção do que é você ser responsabilizado por uma coisa que você não sabe o que é”?

Luango, agora com 18 anos, acaba de encerrar sua medida socioeducativa de L.A., tinha suas hipóteses por que estava ali. "Ele me chegou, foi me contar que ele tinha brigado com o vizinho, arranhado o carro do vizinho e também tentou roubar o celular do vizinho", isto ocorrera quando ainda tinha 16 anos, conta a profissional que o acompanhava.

Vindo de um serviço de medida em meio aberto de outro Município, após autorizada a transferência pelo Poder Judiciário, Luango vivia com sua avó à época da entrevista, moradora da Vila Gilda, na região Sul de São Paulo. Após brigar com esse vizinho, foi ameaçado de morte pelo mesmo, então sua mãe pediu que o jovem passasse a viver com a avó. Feita a mudança de residência e de serviço de referência, a profissional pode compreender melhor seu caso. "Eles têm dificuldade de compreender um documento que chega na casa deles, do Judiciário ou da Defensoria Pública, eles trazem pra gente às vezes". "Olha, chegou esse papel aqui lá em casa”. A família muitas vezes também não compreende os documentos recebidos, sendo preciso que os profissionais expliquem aos jovens e a suas famílias o conteúdo.

Apesar do que pensava Luango, o estranhamento da profissional foi maior ao descobrir a acusação que sustentava a medida socioeducativa do jovem. "Ele chegou dizendo isso (o conflito com seu vizinho), só que ele estava aqui por injúria”. Numa discussão com sua mãe, Luango verbalizou palavrões e a mãe o havia denunciado...

Zazi, o outro profissional que acompanhava essa história, relata seu hábito de perguntar, após a leitura de algum documento judicial junto com o jovem em 
atendimento, "você entendeu o que tá escrito aqui? Ficou com alguma dúvida"? "Muitos me respondem: 'desculpa, mas eu não entendi nada"'.

O trajeto de institucionalização e o cumprimento da medida parecem também, segundo os relatos, confundir a cronologia do jovem, como na fala de Ewá, que acompanhou Luango:

[Ewá] - E eles até chegam a se perder por um tempo. Esse meu menino, quando eu fiz o encerramento [de medida socioeducativa] dele, eu mostrei pra ele que o juiz tinha feito o encerramento. Ele leu, e o começo [do documento] o juiz dizia assim, - não lembro bem as palavras -, "constatamos que o adolescente está há dois anos... dois anos e meio" ... E ele olhou pra mim, "nossa, eu já tô com todo esse tempo"! Nem ele não sabia mais, sabe, tanto tempo...

A história de Luango reflete a produção de estranhas marcas biográficas na vida do jovem pelo cumprimento da medida socioeducativa. Há uma dissonância cognitiva e temporal, não sabe exatamente o que fez e por que está cumprindo o desagravo, não sabe mais por quanto tempo terá de cumprir o mesmo e qual a dimensão da reparação de um ato infracional que supõe ter cometido. Deste modo, é difícil pensar que Luango teria a oportunidade de refletir e responsabilizar-se pelo "erro" ou pelos "erros", que cometera ou que planejara, a partir da imposição de uma medida socioeducativa de Liberdade Assistida, uma vez que o trabalho socioeducativo ocorreria a partir de suas concepções a respeito do que fez, e a possibilidade de ressocialização se daria partindo das mesmas.

Temos poucas informações na história de Luango, além do que Ewá nos conta. Porém, chama também atenção que os profissionais entendem o trabalho social como uma intermediação feita junto às famílias (Furtado et.al., 2016), trabalho que cabe constantemente o cuidado, evitando que passe pela individualização das responsabilidades, ou pela "reprivatização" de questões públicas e políticas (Schuch, 2014). No entanto, o processo em que Luango foi inserido parece apresentar um 
caminho inverso, talvez tenha ocorrido uma desresponsabilização / republicação / "reestatização" da família, que de alguma forma tenta "devolvê-lo" para o Estado, para que dê conta de seus conflitos e demandas.

Assim como Luango, podemos pensar em outras histórias de jovens negros e moradores de áreas periféricas de centros urbanos que também são levados a um "processo kafkiano" sem compreender as condições e a extensão do cumprimento da penalidade de que são acusados e condenados. Atendendo à autoridade policial e judicial e, por vezes, na incerteza de terem ou não cometido uma infração - infração outra, que não a de serem jovens, negros e de viverem na periferia.

\section{História do filho de Sobá}

Aqui chamaremos de Oyá, nossa interlocutora, que relata uma história que acompanhou em uma reincidência na medida, do jovem Ajagunã, 18 anos, negro, filho de Sobá. "Tava em medida, aí ele foi apreendido novamente e retornou pra cá”.

Em seu breve retorno à família, Ajagunã se envolve no que Oyá chama de "uma situação", tratando por possíveis conflitos ou infrações, mas que não se tem muita informação do que se trata.

[Oyá] - E quando ele retorna, bem no início da medida, a mãe dele falece. A mãe dele morre. Só que tem toda uma situação em torno disso, a mãe dele, ela tem um infarto, só que esse infarto se dá quando ela sabe de uma situação que tá sendo com ele. Porque ele havia sido pego, por pessoas até então não identificadas. E nessa coisa de não saber o que tava acontecendo e tal, ela veio a enfartar, e ele foi preso.

Oyá conta de seu envolvimento e de toda a equipe, que chegou a acompanhar a família para a realização do velório da mãe, tendo também de comparecer ao Fórum, em razão da prisão de Ajagunã. 
[Oyá] - Ele foi preso, porque ele tinha 18 anos. Ele começou a cumprir a medida, foi apreendido novamente, foi pra Fundação Casa. Quando ele sai, com 18 já, e mesmo assim ele sai com L.A. Então como ele já tinha 18, ele foi pro CDP. E o que fica dessa história, pra resumir, é o que... É... tem um entendimento da família, e acho até que de parte da sociedade, de que esse menino é responsável pela morte da mãe. Porque a mãe infartou, né? Dele também... Tem esse sentimento também.

A noção de "nervoso", que tomamos de teóricos das ciências sociais (Duarte, 1986; Pelúcio, 2009), parece fazer sentido nesse contexto, quando sintomas físicos e morais se entrelaçam mediante a "situação" na qual Ajagunã está implicado, levando ao colapso de Sobá, que então descobrimos ser a verdadeira protagonista desta história.

[Oyá] - Eu fui pesquisar pra entender as questões do infarto, o que provoca. Você precisa, falta de qualidade de vida, de uma boa alimentação, de uma boa moradia, tudo isso! Aí você vive toda uma vida dessa, de pobreza, de vulnerabilidade social, ter que enfrentar o cárcere, ter que passar visita vexatória. Tudo isso, o olhar da sociedade encima dessa pessoa.

"Fico pensando", prossegue o relato, "quanto essa mulher não já estava sendo assassinada aos pouquinhos, por tudo isso que já vinha passando? Tanto com esse filho, como com outras questões". Entre essas questões, o desemprego, o cárcere, e a política de benefícios sociais, conforme relatou Oyá, acompanhada de outra profissional que também acompanhou o caso, aqui chamada de Iemanjá. "O desemprego assolava parte da família inteira, praticamente. Tinha [...] que lidar com o desemprego também, [e] mais membros da família no cárcere”.

[Oyá] - Qualquer pessoa mais conservadora vai dizer, "é uma família, então, que já é problemática, que já é do crime, porque tem mais pessoas envolvidas". Mas eu olho pra isso, entendo o contrário. Que sistema é esse? Tão cruel, que faz com que mais membros de uma família tenham que passar pelo cárcere. Inclusive a matriarca dessa família vem a falecer por conta disso. Porque, pra mim, ela foi assassinada. O Estado matou essa mulher. Ela não simplesmente morreu.

Iemanjá completa o relato: "Ela tava sob avaliação do INSS. Ela tava morrendo de medo". Oyá retoma, explicando que Sobá teve um câncer quando Ajagunã ainda era 
recém nascido. Em seus dois primeiros anos de vida, fora criado por outras pessoas, pois a mãe enfrentava as consequências de uma grave doença. "Em razão disso, ela recebia um benefício do INSS, e naquele período, ela ia passar por uma reavaliação desse benefício”. Sobá passava por dificuldades e muitas preocupações, principalmente no que cabia seu sustento e de sua família. "E se perde esse benefício?". O sustento familiar, num contexto sistêmico de desemprego, baseava-se na renda gerada a partir desse benefício, conforme contam as profissionais, "a renda da família inteira era essa", e, a qualquer tempo, poderia ser retirado.

[Oyá] - Eu vejo dessa maneira, essa mulher foi assassinada, foi executada, sim, por esse Estado! O Estado que é perverso. Que quando é presente, é pra punir. Vou comparar até com um pai que é ausente, que quando é presente, ele pune.

Por seu argumento, o Estado passa pela compreensão em diferentes dimensões, tomamos sua metáfora "paternal", levando a diferentes consequências: é um pai que administra mal seus recursos; é um pai punitivo; e é um pai ausente. No primeiro aspecto, mantém um benefício que não dá conta das reais necessidades da família, como o acesso ao trabalho e renda a seus membros e a programas de inclusão; ao mesmo tempo em que busca o controle (pela vida institucionalizada dessa família), não sabe como gerir seus investimentos e recursos (mantém o benefício como um arranjo substitutivo a políticas de inclusão social). É punitivo, oferece constantes ameaças (do corte de benefícios, das penalidades pelo descumprimento das regras), manifesta-se em tempo para reprimir "situações", e tem o cárcere como medida principal para enfrentamento da violência e da pobreza. É enfim um "pai ausente”, não só com a família, mas com suas políticas sociais e com os trabalhadores que as executam, parece não dar conta dos recursos de reinserção social (Ajagunã cumpria reincidência infracional quando foi de novo aprisionado), demonstrando a necessidade de 
investimento e de ofertas de recursos para as políticas socioeducativas de meio aberto. O Estado tem condutas ambíguas, assumindo diversas "faces" para a família de Ajagunã e Sobá, entre elas, a da institucionalização e a afetiva, da medida em meio aberto, mas também a do controle e da morte.

\section{A história de Ajalá}

A técnica Lembá começa essa história anunciando que "quando se tem um coração batendo aqui, a gente se envolve", reafirma que há muitos casos que a mobilizam emocionalmente, que não tem como evitar se envolver ${ }^{42}$. Em alguns desses casos, entende que faltam a algumas das famílias recursos de diversas ordens, o que aumenta às crianças e aos jovens sua exposição a situações de violação.

“A família passando por... as crianças passando por situações inúmeras de violação. Uma família que, por várias questões, nem vou falar de julgamento, não dá conta de cuidar de seus filhos. Então seus filhos praticamente se criam sozinhos". Esta fala destacada talvez remeta ao que compreendemos enquanto estratégia de individualização. Uma vez que há uma "trama social" como pano de fundo às questões tratadas (Scisleski et. al., 2008), a relação instituição-família, no entanto, nem sempre tende a identificar, problematizar ou desconstruir essas tramas. Em certos casos, provavelmente, nem seja possível pelos trânsitos difíceis entre instituição e famílias.

O entrevistador questiona se os filhos estavam em situação de rua. "Eles conhecem e têm acesso a... Estão vulneráveis, aí começam com uso de drogas muito cedo, criança já fazendo uso de drogas. Aí largam a escola, e vão pra rua. Aí começam a

\footnotetext{
${ }^{42}$ Destacamos o "envolvimento" apontado em sua fala, pois, novamente, denota a importância de um repertório marcado por relações, que será diferencial importante na descrição das trajetórias dos jovens em atendimento junto aos SMSE/MA.
} 
fazer furtos pra poder bancar seu vício". A "adesão" ao tráfico, ao furto e às práticas infracionais surge ligada a percursos relacionais, a uma socialização que seria tipicamente "da rua", e culminaria no desenvolvimento do uso abusivo de substâncias.

A técnica relata os esforços institucionais para "inserir essa família nos serviços que poderiam fortalecer. Dentro da [Política de] Assistência Social, serviços de apoio à mulher vítima de violência, UBS"... neste ponto, a interrompemos, perguntando sobre a situação de violência familiar. A profissional, movida pelas lembranças e pela emoção que o caso lhe evoca, assim como, pelos arranjos institucionais tomados na condução deste caso, que passa pela priorização na defesa dos direitos do adolescente, partindo, por consequência, na responsabilização familiar, não menciona esse episódio e segue para a descrição do que ocorre na história de Ajalá:

[Lembá] - A parte pior pra mim foi quando ele foi internado pelo uso de drogas. E foi chocante assim... A gente foi fazer visita lá no Hospital Lacan, que é o hospital [psiquiátrico]. E você chega lá, o menino tá babando de tanto remédio, que dão pra ele... Até comer um [chocolate da marca] Bis, começa a babar o chocolate... Você lê no livro, você vê isso [na graduação] no Serviço Social, você vê falando da Reforma Psiquiátrica, como eram os manicômios... Você ir lá e ver é outra coisa. É um lugar assim que, se de alguma forma eu contribuir pra esse menino não entrar lá nunca mais, em nenhum caso; eu vou lutar com unhas e dentes pra ninguém mais ir num lugar desses. Horrível!... E aí, o menino, quando ele foi pra lá, ele tava respondendo por um novo ato, aí ele saiu do Lacan e foi [encaminhado] para a Fundação Casa. Ficou lá na Fundação Casa. Até a Fundação Casa ficou assim, "gente, o que tá acontecendo com esse menino? porque ele tá dopado de remédio?". [...] Houve uma mobilização da Fundação Casa pra que ele passasse com psiquiatra, pra diminuir o remédio, porque eles não podem, da cabeça deles, diminuir. Daí, depois de um tempo já que ele estava lá, conseguiram passar ele no psiquiatra do CAPS aqui da região, respeitando que [já que] um dia ele voltaria pro território, ele ia passar no CAPS da região dele. Reduziu o remédio, tudo, ele até fazia xixi na cama, de tão dopado que ele tava. Isso ficou, acho que [...] quase um ano entre Lacan e Fundação Casa. E foi difícil pra conseguir a liberação dele. A gente mobilizou a Rede pra que ele não fosse pra Fundação Casa, pra que, do Lacan, ele viesse pra casa. Alegando que a questão dele não era questão do ato infracional, a questão dele era uma questão de saúde. Ele fez furtos porque ele queria manter o vício dele. E não rolou. Ele foi pra Fundação Casa do mesmo jeito... Agora ele saiu, a indicação é que fosse direto pro SAICA. 
Ajalá ficou cerca de um ano entre a internação hospitalar no Hospital Lacan e a medida de internação na Fundação Casa. Agora estava em processo seu encaminhamento para a retirada do convívio familiar e sua institucionalização junto ao Serviço de Acolhimento Institucional de Crianças e Adolescentes (SAICA).

A técnica relata que este foi o entendimento de um trabalho da rede socioassistencial e de saúde, que acompanha o grupo familiar. Ajalá e seus irmãos logo serão novamente institucionalizados no SAICA, devido a um longo trabalho institucional mediador dessas relações entre a família e os direitos das crianças e jovens.

[Lembá] - Porque desde 2011, a família tá sendo atendida pela Rede. Tá o caso no Conselho Tutelar e são várias violações. Nesse momento, a gente olha e a gente se sente impotente. Você olha pra vida de uma pessoa: você passou por um hospital psiquiátrico, foi pra Fundação Casa, e daqui a pouco tempo você pode ir pra um SAICA, com 15 anos [de idade] você tem uma história dessas.

O entrevistador fala que Ajalá não teve direito à convivência familiar, nem à convivência em sociedade, uma vez que sua história de vida é contada sempre internado em alguma instituição. Oliveira et. al. (2018) apresenta-nos a noção de "transinstitucionalização", onde processos de institucionalização / internação se associam em substituição aos modelos tradicionais, fazendo com que equipamentos e serviços de saúde e socioassistenciais ("circuitos socioassistenciais-sanitários”) operem numa lógica híbrida de medicalização e confinamento. Conforme os autores, "crianças e adolescentes" tornam-se "peregrinos de lugar nenhum, percorrem continuamente cadeias de serviços especializados, cujas respostas são fragmentadas e pontuais, produzindo circuitos de abandono e cronicidade" (p. 230).

Nesse momento, a profissional se reapropria da noção que Scisleski denomina "trama social", e diz que a responsabilização não passa somente pela organização familiar no caso de Ajalá: "Por um lado você olha, realmente essas crianças estão sendo 
negligenciadas. Talvez tenha chegado ao ponto que chegou por isso. Mas por um Estado ausente". A negligência familiar é então intermediada por negligências de uma esfera menos circunscrita, passando pela pobreza e pela violência. "Por várias questões que não foram olhadas. E a gente se sente impotente, quando vê um negócio desses. Porque você fala, poxa, a vida é uma só, gente! E ele tão novinho já passou por tanta coisa, tanto sofrimento, sabe? Tanta privação, tanta violação"!

A profissional relata seu desejo que as situações fossem diferentes, de fato, fala das limitações de sua atuação sobre complexas situações onde vulnerabilidades e violações de direitos, de crianças e adolescentes, mas também de famílias e de um território, são generalizados.

\section{A história de Kokueto e o devir mar}

Gu é o profissional que relata a história de Kokueto, tendo o acompanhado durante alguns anos. Sua mãe mudara para o interior. A família de Kokueto era numerosa, vivendo numa mesma casa muitas crianças pequenas, todos mantidos pela avó, que trabalhava, porém enfrentava dificuldades. Por algum tempo, o profissional intermediava até mesmo a relação entre esse jovem e sua família.

[Gu] - Quase que diariamente, tinha que ir na casa dele lá, pra tá ajudando a família, tá conversando com o adolescente pra saber o que tava acontecendo... Por uso de drogas e também por furtos que ele realizava na comunidade. Aí ele era ameaçado de morte, aí a avó me comunicava, tinha que ir lá correndo.

Neste percurso infracional, Kokueto passaria a ser perseguido e ameaçado de morte na região onde morava. Foi preciso acionar o Programa de Proteção à Crianças e Adolescentes Ameaçados de Morte (PPCAAM), programa estadual que acolhe 
institucionalmente crianças, adolescentes e jovens que se encontrem sob ameaças ou a quem identifiquem-se riscos à vida.

Após o PPCAAM, seu percurso passaria ainda pela internação em um hospital psiquiátrico para tratamento de uso abusivo de drogas. E o mesmo técnico o acompanhou nessa trajetória interinstituições. "Uma vez por semana, pelo menos, tinha que ir lá na casa. Era ligação quase que todos os dias, contato com a família. [...] Várias discussões de caso com a equipe, com o pessoal do CREAS".

Com esse vínculo estabelecido, forjado pelas inúmeras dificuldades de convivência e registrado por um grande número de instituições, Kokueto segredou ao profissional algo: "ele falou que nunca tinha visto o mar. Eu acho que até hoje, acho que não conhece, nunca foi à praia”.

A equipe coletivamente planejou conferir o encontro de Kokueto com o mar. Os profissionais que ouviam a história relembram que muitos dos jovens atendidos no serviço relatam o desejo de conhecer a praia. “A gente já pensou várias vezes em [fazer] um bate e volta, pelo menos" - conta Iemanjá, outra profissional que acompanha a história.

Gu relata o planejamento que fizeram do roteiro, no caso de Kokueto: saindo às 05h da manhã do serviço de medida socioeducativa, indo pelo Terminal Rodoviário Jabaquara, e retornando no mesmo dia, no período da tarde. "Mas aconteceu alguma coisa, e acabou que não aconteceu", conta o profissional com certo ressentimento.

[Gu] - Hoje, infelizmente, ele encontra-se... Tá preso, na Casa de Detenção. Já tá maior de idade... Mas foi uma situação assim, um caso marcante pra mim... Até uma vez, ele foi pra Fundação Casa, ele me chamou de pai. A gente tava, acho que nem o pai dele, que ele não conhecia, fizesse isso pra ele.

Tão forte foi o vínculo estabelecido entre o jovem e o profissional, cujo papel extrapolava suas funções enquanto técnico de medida socioeducativa, de modo a 
intervir diretamente nos conflitos e na dinâmica familiar, que o mesmo passou a ser percebido por Kokueto como o pai, melhor até que o pai que não conhecera, sendo uma referência ainda mais importante, afirmada por estar presente.

A história de Kokueto e o mar, que não conheceu, é a de quem não sabia bem como se colocar em relação às situações, que se envolveria em atos infracionais, enfrentaria o uso abusivo de substâncias, e que, passando por tantos registros de instituições, repetiria e seria repetidamente aprisionado. No seio familiar, Kokueto teve avó, teve irmãos e uma família grande para uma pequena casa - uma "casa dos vinte". Não temos dados que indiquem como lidava com as ausências paternas e maternas e, em última instância, essas podem também remeter a ideais familiares inalcançáveis, pois sua família se reorganizava, buscando novas referências. Para Fonseca (2005), as famílias existem para "além do ideal normativo" em "outros arranjos, outras possíveis estruturas familiares” que possam “ordenar as práticas e dar sentido à existência” (p.56).

Ainda assim, as informações indicam que convivia com a falta, num sentido mais amplo e estruturante, de condições, de acesso a políticas econômicas, de moradia, saúde... Pensando no conceito de Vicentin (2012), Kokueto atravessou o “descriançável”.

Kokueto não teve seu lugar de filho. Felizmente, encontrou um pai. Um aliado ao seu "criançar" (VICENTIN, 2012).

Esse mar nessa história é interessante pela oferta que parece apresentar a Kokueto, assim como aos demais jovens atendidos pelo serviço, de extrapolar os limites de suas possibilidades, de lavar suas histórias maculadas por políticas, instituições e soluções que limitam seus percursos de vida, num ciclo de delitos e penalidades marcado pelo controle e encarceramento. O mar é a esperança de liberdade. E a imersão 
do profissional e da equipe neste projeto marítimo é uma bonita e sensível iniciativa de reconhecimento dos sujeitos em sua humanidade, conflitos, necessidades, desejos, devires. 


\section{CONSIDERAÇÕES FINAIS}

O objetivo deste tópico é retomar o percurso de pesquisa traçado, de modo a repensar aquilo que inicialmente foi planejado, frente ao material colhido em campo e às discussões promovidas a partir do mesmo.

\section{Revisitando as hipóteses e questões}

As questões a princípio colocadas: "como se revela nos discursos institucionais do sistema de atendimento socioeducativo os modos de constituição / construção desses sujeitos (os jovens em conflito com a lei)"? "Como os cenários decorrentes da violência e da pobreza estruturante, assim como o encarceramento e o racismo, aparecem nos discursos institucionais e são compreendidos ou reproduzidos no cotidiano dos profissionais do sistema socioeducativo"?

Discutimos com base nos relatos de práticas discursivas que percorrem as falas, e incluem discursos que concorrem na produção de uma "semântica do menino" e uma "semântica do bandido". A primeira, mais frequente nos serviços de medidas socioeducativas do meio aberto, fala de um caráter relacional, um vínculo social, que se constitui entre os profissionais desses serviços junto aos jovens em atendimento, passa também por uma relação geracional, que afirma o caráter etário desses “meninos”, um reconhecimento de sua juventude e, talvez, em alguma medida incluindo-os em tecnologias de cuidado, no sentido denominado por Vicentin (2012) de "criançar o descriançável”, potencializando uma aliança com o “criançar", isto é, resgate de potenciais sufocados de experimentação juvenil, empobrecidos pelas violações, (como a 
institucionalização). A semântica do bandido nos é contada como discursos que circulam no sistema de internação, que conta de práticas que remetem ao regime do sistema FEBEM, resíduos de condutas de irregularidades que se reproduzem, também em outros setores da sociedade, até mesmo nas relações pessoais e familiares dos profissionais que atuam nas MSE, discursos que apontam os jovens como "execráveis" e "bandidos", e confrontam também aqueles que trabalham pela proteção integral, numa posição de "defensores de bandidos".

Nos discursos, os cenários da pobreza estruturante, muitas vezes remetem ao histórico de ocupação e desenvolvimento dos territórios periféricos, ao qual subscrevem os SMSE/MA com os quais dialogamos.

As medidas de encarceramento são compreendidas como soluções dispostas pelo "Estado", os profissionais falam sobre esse mesmo Estado como multifacetado, fragmentado, o que remete à noção de capilaridade do poder, estabelecida por Foucault (2010). Por alguns de seus setores e agentes, investe fortemente em tecnologias repressivas e punitivas, "deixa morrer" ou "faz morrer" pessoas, num sentido biopolítico (Foucault, 2005), atua pelo desinvestimento nas políticas protetivas. Por outro dispõe de propostas e agentes que defendem a proteção social e formação de vínculos.

As questões raciais são identificadas e pautadas pelos SMSE/MA, porém em ações específicas, programáticas, os relatos apontam ainda para uma "sociabilidade" racial dada pela internação na Fundação Casa, a partir da qual os jovens passariam a se reconhecer "negros". 
Estabelecemos as correlações a seguir na intenção de descrever uma relação com as hipóteses inicialmente formuladas:

1) "nos discursos do sistema de medidas socioeducativas uma compreensão do Estado e da sociedade, menos como um sistema ordenado de garantias, mais como um sistema pró-beneficente, onde as soluções sejam individualizantes para as trajetórias de vida do público em atendimento, particularmente, de jovens negros moradores de periferias da Zona Sul de São Paulo, circunstanciados pela situação conflitiva com a lei", os relatos falam de um "Estado" que são "os Estados", que são seus agentes e suas agências, são aqueles que utilizam dos meios de poder de alguma forma em relação ao sistema socioeducativo. Compondo também um sistema de ambiguidades de práticas, saberes, condutas e discursos. O Estado apresenta sua face protetiva que convive ou resiste com um regime discursivo de austeridade, nos dá a impressão, em alguns registros, de um Estado "sob ameaça” do Estado, ou dos Estados. Ameaça que muitas vezes se confirmam por meio do "abandono" de funções de promoção de direitos/ protetivas, a partir da precarização. O Estado "bate à porta" do jovem de periferia argumento em conformidade com as entrevistas, com a missão, antes de tudo, de punir, e contraditoriamente essa via de punição pode, tardiamente, incluir jovens e famílias negras, pobres, moradoras de periferias, em programas e políticas sociais.

2) "soluções individualizantes para trajetórias de vida" - inscritas no sistema de medidas socioeducativas desde seus instrumentos, como o PIA e os atendimentos individuais, os profissionais entrevistados demonstram tentativas de, simultaneamente, se conformar e resistir à redução técnico-burocrática de suas funções. Aderem num primeiro momento às demandas, buscando encaminhamentos e recursos que contornem 
a individualização, de modo a posicionarem-se de acordo com os contextos - de origem de classe e região, daqueles jovens - então ignorados na imposição da medida. Nossos entrevistados denunciam as dificuldades de um trabalho com outros setores e agentes tanto integrantes deste sistema socioeducativo, como o Poder Judiciário, e até mesmo serviços de educação, saúde e de assistência social.

3) "encarceramento elou violências são as respostas mais frequentes do Estado com relação à população jovem em situação vulnerável" - são a primeira resposta, a mais ágil, conforme os relatos, é "quando o Estado bate à porta”, pela primeira vez. As medidas de inclusão socioassistencial - quando ocorrem, serão pensadas, conforme os relatos, num segundo momento, serão posteriores à inscrição do jovem num sistema institucional punitivo e, na maior parte das vezes, restritivo ou privativo de liberdades individuais e sociais.

\section{Dos objetivos e do percurso}

Entendemos a descrição dos objetivos de pesquisa neste ponto a partir do percurso realizado, passando pela compreensão a partir dos relatos de profissionais do sistema socioeducativo, de descrições feitas por estes acerca do acesso aos programas e políticas do Estado feito pela juventude em conflito com a lei e moradora de periferia, através de suas experiências no trabalho socioeducativo desenvolvido na Zona Sul do Município de São Paulo.

Buscamos estabelecer debates, a partir das narrativas de profissionais do sistema socioeducativo, atuantes nos distritos: Capão Redondo e Fundão do Jardim Ângela, pertencentes à Zona Sul do Município de São Paulo, sobre questões estabelecidas, na perspectiva desses profissionais, acerca dos encaminhamentos pelo Estado para os 
jovens inscritos no sistema socioeducativo e moradores de regiões periféricas no que tange a seu acesso a políticas sociais, seus vínculos e relações sociais e familiares, e aos seus contextos territoriais.

Buscamos compreender e discutir as concepções e descrições feitas por estes profissionais a respeito das dinâmicas do trabalho, o trânsito das políticas socioeducativas junto às demais políticas, e sua relação com os jovens em atendimento nos serviços.

Tratamos ainda de levantar, a partir dos relatos desses profissionais do sistema socioeducativo, histórias, numa implicação com as políticas de narratividades (Passos e Benevides, 2009), oferecendo contornos que possibilitaram a discussão sobre o acesso / exclusão desses jovens em atendimento socioeducativo às políticas sociais e aos direitos.

A pesquisa inicialmente previa uma etapa de interlocução direta com os jovens, na modalidade pesquisa-intervenção, que não ocorreu, reconhecemos este como um ponto delicado, no sentido que não dá voz diretamente aos sujeitos, identificados pelos dados que obtivemos como excluídos de direitos e atravessados por vulnerabilidades. Por outro lado, fizemos tentativas de evitar uma produção enviesada no que Vicentin (2006) identifica como "hipercomunicação" na relação entre adultos e crianças e jovens, a partir da qual, os saberes e narrativas acerca da juventude se constituem sempre pelos saberes (e dizeres) dos adultos, produzindo uma "sobreimplicação imposta à criança (ao jovem, em nosso caso) pelo adulto", na qual o jovem "fica sem voz e sem lugar".

Em nosso percurso, contamos com importantes colaboradores, que falam sobre os jovens (e também, sobre si mesmos, a partir da dimensão de seu trabalho junto aos jovens) que demonstraram importante sensibilidade a questões sociais, como a 
desigualdade e a violência, pois não somente, lidam com estas questões como buscam estratégias de resistências.

Caminhamos, pensando uma implicação do pesquisador no discurso, numa jornada em direção ao Sul do Município onde os dados que conhecíamos de estatísticas, de "ouvir dizer", se apresentam com outras possibilidades. Falar de jovens e ouvi-los assobiando nas ruas ganham dimensões diferentes, o que acreditamos significativo no contexto da pesquisa. Falar sobre o trabalho socioeducativo, e ouvir diretamente dos trabalhadores desse sistema seus desafios e dificuldades, mas também aquilo que os envolve e motiva, narrarem a partir dos seus próprios vínculos foi, em nosso entendimento, um trajeto importante no âmbito do planejamento da pesquisa.

\section{Questões que ficam}

Neste tópico, optamos pela produção, não conforme uma lógica geradora das respostas, como "vontade de verdade" da produção de saberes, da qual trata Foucault (1996). Buscamos aqui um aprendizado pela dimensão expressiva, descrita por Passos e Benevides (2009) a partir da política de narratividade, pelo que entendemos ser descritível na implicação do pesquisador em determinada localidade.

Dito isto, o pesquisador se coloca na posição de quem tem mais dúvidas. Do sentido deste trabalho num interstício transformacional dos acontecimentos sociais. A partir deste interstício, especulamos um movimento de descontinuidades no curso narrativo e institucional pós-abertura democrática e garantidor de direitos, onde algumas dessas faces do Estado se apresentam. Ao tempo de conclusão desta pesquisa, propostas como a redução da idade penal despontam no cenário institucional político. Ao passo que, conforme os relatos, já ocorrem encaminhamentos mais austeros, inscritos no 
sistema de medidas socioeducativas, como medidas de internação mais longas, medidas sobre medidas, ou encaminhamentos institucionais que percorrem outras formas de reclusão, como internações psiquiátricas hospitalares, acolhimento em SAICA, entre outros.

As relações de mercado informal e formal, parece-nos, a partir do resgate do histórico de ocupação dos territórios estudados, dos relatos e registros de campo, perfazem em alguma medida a organização dos bairros periféricos estudados. Pelo que observamos, as redes de comércio do tráfico são parte desse mercado - é importante destacar que não são o todo, tendo em vista a desconstrução de estigmas acerca dessas regiões e de seus moradores, - dinamizam o acesso ao trabalho distribuindo oportunidades territoriais de acesso à renda, que diferem e muitas vezes superam os recursos e as oportunidades disponíveis pelo mercado formal e pelas políticas de assistência social. Cabem em nosso entendimento maior produção de estudos locais sobre essas questões, bem como, aumento de propostas nas esferas públicas e sóciocomunitárias voltadas à inclusão e ao acesso a renda dos jovens e famílias.

Finalmente, pensando no regime de austeridade e nessa limitação de recursos que se impõem sobre as políticas sociais, percebemos, por meio de seus relatos, os profissionais do sistema de medidas socioeducativas muitas vezes desmotivados ou sentindo-se impotentes frente às situações que lidam no cotidiano do trabalho. Seu campo de atuação é muitas vezes levado a limites, tendo como consequência um sentimento de impotência relatado com frequência, confirmando a limitação dos recursos protetivos disponíveis. Além disso, sua valorização enquanto profissionais é também constantemente ameaçada por discursos conservadores na sociedade e até mesmo por condutas de outros agentes de Estado, o que impõe maiores limitações no 
desenvolvimento do trabalho socioeducativo efetivo e em rede, articulando e implicando setores de segurança pública, o Poder Judiciário e órgãos de saúde, assistência e inclusão social, trabalho e educação. As próprias politicas socioeducativas, de que são representantes, parecem questionadas por representantes da sociedade e do Estado, produzindo uma desvalorização de seus campos de conhecimento e atuação. A desvalorização é, muitas vezes, superada pela participação nas militâncias ou pelas estratégias de gestão e pelo trabalho das equipes. Entendemos que há da parte de muitos dos nossos entrevistados uma organização para a resistência, e cabe o reconhecimento dessa forte articulação.

O que emerge como inesperado neste campo é, certamente, o aspecto afetivo que mobiliza nossos interlocutores no desempenho de suas funções. O olhar, a escuta e a sensibilidade, a disponibilidade que ofertam aos jovens e famílias, a participação em suas vidas apresentam-se como uma disposição em estar juntos, "alguém com quem contar" (Sposati, 2011). O envolvimento com os jovens e famílias, que muitas vezes se entrelaça nas instituições familiares, compartilhando suas questões, em nome de uma configuração de vínculos sociais que, em nossa perspectiva, é uma resposta interessante a estratégias encarceradoras. 


\section{REFERÊNCIAS BIBLIOGRÁFICAS}

ADORNO, Sérgio. A experiência precoce de punição. In: Martins, Jose (org.). O massacre dos inocentes: a criança sem infância no Brasil. São Paulo: Hucitec, 1993.

AGAMBEN, Giorgio. Homo sacer: o poder soberano e a vida nua. Belo Horizonte: Editora UFMG, 2007.

ANDRADE, Lucimary Bernabé P. ANDRADE, L.B.P. Educação infantil: discurso, legislação e práticas institucionais [online]. São Paulo: Editora UNESP; São Paulo: Cultura Acadêmica, 2010.

ARANTES, Esther Maria de M. De Criança Infeliz a Menor Irregular - vicissitudes na arte de governar a infância. In: JACÓ-VILELA, Ana Maria et. al. (org.). Clio-Psyché: Histórias da Psicologia no Brasil. Biblioteca Virtual de Ciências Humanas do Centro Edelstein de Pesquisas Sociais - Rio de Janeiro: UERJ, NAPE, 2008.

ARANTES, Esther. Considerações sobre as propostas de redução da maioridade penal e agravamento da medida socioeducativa de internação. In: MAGALHÃES et. al. (orgs). Mitos e verdades sobre a Justiça Infanto Juvenil Brasileira: Por que somos contrários à redução da maioridade penal. Conselho Federal de Psicologia. - Brasília: CFP, 2015.

ARAÚJO, José Duarte. Polarização epidemiológica no Brasil. Informe Epidemiológico do SUS. 1992. Republicado em: ARAÚJO, José D. Polarização epidemiológica no Brasil. Epidemiol. Serv. Saúde, Brasília , v. 21, n. 4, p. 533-538, dez. 2012 (1992).

ARIÉS, Philippe. História social da criança e da família. Rio de Janeiro: Editora Guanabara, 1986.

AYRES, José Ricardo C.M. O conceito de vulnerabilidade e as práticas de saúde: novas perspectivas e desafios. In: CZERESNIA, D; FREITAS, C.M. (org.). Promoção da saúde: conceitos, reflexões, tendências. Rio de Janeiro: Editora Fiocruz, 2009.

BARBOSA, Irene. Socialização e identidade racial. Cadernos de Pesquisa (63). São Paulo: Fundação Carlos Chagas, 1987.

BARBOSA, Marialva. A narrativa, a experiência e o acontecimento fundador de novos regimes de visibilidade da TV brasileira. Tempo, vol. 9, núm. 17, Niterói: Universidade Federal Fluminense, 2004.

BENJAMIN, Walter. Magia e técnica, arte e política: ensaios sobre literatura e história da cultura - Obras escolhidas volume 1. São Paulo: Brasiliense, 1994.

BIEHL, João. Antropologia do devir: psicofármacos - abandono social - desejo. Revista de Antropologia USP v. 51, n. 2, São Paulo, 2008. 
BORELLI, Elizabeth. Vulnerabilidades sociais e juvenil nos mananciais da zona sul da cidade de São Paulo. Rev. katálysis, Florianópolis, v. 15, n. 1, p. 62-69, June 2012. BORELLI, Elizabeth. Vulnerabilidades sociais e juvenil nos mananciais da zona sul da cidade de São Paulo. Rev. Katálysis, Florianópolis, v. 15, n. 1, 2012.

BOURDIEU, Pierre. A "juventude" é apenas uma palavra - entrevista com Pierre Bourdieu. In: BOURDIEU, Pierre. Questões de sociologia. Rio de Janeiro: Marco Zero, 1983.

BRASIL. Decreto 6.481 de 12 de junho de 2008. Disponível em: <http://www.planalto.gov.br/ccivil_03/_ato2007-2010/2008/decreto/d6481.htm> Acesso em 20.12.2018.

BRASIL. Lei $\mathrm{n}^{\circ} 12.852$ de 05 de agosto de 2012. DOU, Brasília, 2012 b). Disponível em: <http://www.planalto.gov.br/ccivil_03/_ato2011-2014/2013/lei/112852.htm>. Acesso em: 24.01.2018.

BRASIL. Lei $\mathrm{n}^{\circ} 12.594$ de 18 de janeiro de 2012. DOU, Brasília, 2012 a). Disponível em: <http://www.planalto.gov.br/ccivil_03/_ato2011-2014/2012/lei/112594.htm>. Acesso em: 13.01.2018.

BRASIL. Lei no 8.069 de 13 de julho de 1990. DOU, Brasília, 1990. Disponível em: <http://www.planalto.gov.br/ccivil_03/Leis/18069.htm>. Acesso em: 13.01.2018.

BRASIL. Secretaria Nacional dos Direitos da Criança e do Adolescente. Levantamento Anual SINASE 2014. Brasília: Secretaria Nacional dos Direitos da Criança e do Adolescente do Ministério dos Direitos Humanos, 2017.

BRASIL. Sistema Nacional De Atendimento Socioeducativo -SINASE/ Secretaria Especial dos Direitos Humanos - Brasília-DF: CONANDA, 2006.

BREAKWELL, G. M.; HAMMOND, S.; FIFE-SCHAW, C.; SMITH, J.A. Métodos de pesquisa em psicologia. Porto Alegre: Artmed, 2011.

BUNGENSTAB, Gabriel Carvalho; CARVALHO, Daniel dos Santos S. de. Possibilidades para pensar a juventude brasileira: diálogos com Pierre Bourdieu e Luis Antonio Groppo. Fragmentos de Cultura, Goiânia, v. 27, n. 1, 2017.

CANESQUI, Ana Maria. As Ciências Sociais e Humanas em Saúde na Associação Brasileira de Pós-graduação em Saúde Coletiva. Physis: Revista de Saúde Coletiva. Rio de Janeiro, v. 18, n. 2, 2008.

CANESQUI, Ana Maria. Ciências Sociais e Saúde no Brasil: Três Décadas de Ensino e Pesquisa. Ciênc. saúde coletiva, Rio de Janeiro, v. 3, n. 1, 1998.

CARMO, Milena Mateuzi. Margem adentro: políticas sociais, sujeitos e resistências na zona sul de São Paulo (Dissertação de Mestrado). Universidade de São Paulo: São Paulo, 2017. 
CARRIL, Lourdes. Quilombo, favela e periferia: a longa busca da cidadania. São Paulo: Annablume; Fapesp, 2006.

CAVALCANTI, Mariana. Do barraco à casa: tempo, espaço e valor(es) em uma favela consolidada. Revista Brasileira de Ciências Sociais vol.24, n.69, 2009.

CEBRAP - CENTRO BRASILEIRO DE ANÁLISE E PLANEJAMENTO. Tráfico de drogas entre as piores formas de trabalho infantil: mercados, famílias e rede de proteção social (Apresentação da pesquisa em slides). São Paulo, 2018.

CERQUEIRA, Daniel et. al. Atlas da Violência 2017 IPEA e FBSP. Instituto de Pesquisa Econômica Avançada: Rio de Janeiro, 2017.

CIDADE ESCOLA APRENDIZ. Diagnóstico socioterritorial do Bairro-escola um olhar sobre microterritórios educativos, São Paulo: Associação Cidade Escola Aprendiz (Publicação online), 2012. Disponível em: <https://www.cidadeescolaaprendiz.org.br/diagnosticobairroescola/>. Acesso em 23.10.2018.

CORAZZA, Sandra Mara. Infância e educação. Era uma vez... quer que conte outra vez? Petrópolis: Vozes, 2002.

COUTINHO, Luciana Gageiro. A adolescência na contemporaneidade: ideal cultural ou sintoma social. Pulsional Revista de Psicanálise ano XVII, n. 181, 2005.

COUTINHO, Luciana Gageiro. Adolescência, cultura contemporânea e educação. In: Estilos da Clínica, Vol. XIV, n 27, 2009.

CRIVELARO, Rodrigo. O que a rebeldia teima? Capturas e resistências nas conferências de juventude em Santa Bárbara D'Oeste (Dissertação de Mestrado). São Paulo: Universidade de São Paulo, 2016.

CRUZ, Elizabete F. Crianças, jovens e suas famílias nas esquadrias da epidemia do HIV/AIDS. Desidades n. 7, ano 3, 2015.

DAS, Veena; POOLE, Deborah (2004). Anthropology in the Margins of the State. Oxford: School of Amercian Reserach Press, 2004.

DAS, Veena; POOLE, Deborah (2008). El estado y sus márgenes Etnografías comparadas. Cuadernos de Antropología Social, Universidad de Buenos Aires, núm. 27, 2008 .

DASSOLER, E.R. Do triângulo da morte ao círculo das artes: um olhar sobre a movimentação cultural da periferia Sul de São paulo. In: Anais do Primeiro Colóquio Internacional Culturas Jovens Afro-Brasil América: Encontros e Desencontros, 2012, São Paulo. Faculdade de Educação da Universidade de São Paulo, Disponível em: $<$ http://www.proceedings.scielo.br/scielo.php?script=sci_arttext\&pid=MSC0000000132 012000100012\&lng=en\&nrm=abn>. Acesso em 23.10.2018. 
DEL PRIORE, Mary. A criança negra no Brasil. In: JACÓ-VILELA, AM., and SATO, L., orgs. Diálogos em psicologia social [online]. Rio de Janeiro: Centro Edelstein de Pesquisas Sociais, 2012.

DUARTE, Elisabeth Carmen; BARRETO, Sandhi Maria. Transição demográfica e epidemiológica: a Epidemiologia e Serviços de Saúde revisita e atualiza o tema. Epidemiol. Serv. Saúde, Brasília, v. 21, n. 4, 2012.

DUARTE, Luiz Fernando. Da Vida Nervosa nas Classes Trabalhadoras Urbanas. Rio de Janeiro: Jorge Zahar, 1986.

FELTRAN, Gabriel de Santis. Fronteiras de tensão: um estudo sobre política e violência nas periferias de São Paulo (Tese de doutoramento). Campinas: Universidade Estadual de Campinas, 2008a.

FELTRAN, Gabriel de Santis. O legítimo em disputa: As fronteiras do "mundo do crime" nas periferias de São Paulo. Dilemas - Revista de Estudos de Conflito e Controle Social, [S.1.], v. 1, n. 1, 2008b.

FERRÉZ. Capão Pecado. Rio de Janeiro: Objetiva, 2005.

FLEURY Sonia; OUVERNEY, Assis M. Política de Saúde: uma política social. In: GIOVANELLA L, et. al., organizadores. Políticas e Sistema de Saúde no Brasil. Rio de Janeiro: Editora Fiocruz; 2008.

FONSECA, Claudia. Concepções de família e práticas de intervenção: uma contribuição antropológica. Saúde e Sociedade v.14, n.2, 2005.

FONSECA, Claudia. Da circulação de crianças à adoção internacional: questões de pertencimento e posse. Cadernos Pagu (26), 2006.

FORACCHI, Marialice M. A juventude na sociedade moderna. São Paulo: Pioneira Editora da Universidade de São Paulo, 1972.

FOUCAULT, Michel. A arqueologia do saber. Rio de Janeiro: Forense Universitária, 2008.

FOUCAULT, Michel. A ordem do discurso - aula inaugural no Collége de France pronunciada em 2 de dezembro de 1970. São Paulo, Edições Loyola, 1996.

FOUCAULT, Michel. Em defesa da sociedade: curso no Collège de France (19751976). São Paulo: Martins Fontes, 1999.

FOUCAULT, Michel. Microfísica do Poder. Rio de Janeiro: Edições Graal, 2010.

FOUCAULT, Michel. Vigiar e punir: nascimento da prisão. Petrópolis: Vozes, 2001. 
FREITAS, Felipe da Silva. Violência e juventude no Brasil: diálogos, controvérsias e propostas de intervenção. Fórum sobre "Juventude e Violência no Brasil e na Alemanha". In: Cáritas Brasileira. Disponível em <http://caritas.org.br/violenciajuventude-brasil-dialogos-controversias-propostas-de-intervencao/874> Acesso em 10.04.2018.

FREITAS, Rita de Cássia S., BRAGA, Cenira D., BARROSI, Nívia V. Famílias e Serviço Social - Algumas reflexões para o debate. In: DUARTE, M. J. O.; ALENCAR, M. M. T. (Org.). Família Famílias: práticas sociais e contemporâneas. 2ed. Rio de Janeiro: Lumen Juris, 2011.

FREYRE, Gilberto. Casa grande \& senzala: formação da família brasileira sob o regime da economia patriarcal. São Paulo: Global, 2003.

FURTADO, Antonia G.; MORAIS, Klenia S.B.; CANINI, Raffaela. O direito à convivência familiar e comunitária de crianças e adolescentes: construção histórica no Brasil. Serviço Social Revista, vol 19, n. 01. Londrina, 2016.

GALDEANO, Ana Paula; ALMEIDA, Ronaldo (coord.). Tráfico de drogas entre as piores formas de trabalho infantil: mercados, famílias e rede de proteção social. São Paulo: CEBRAP; 2018.

GIL, Antônio Carlos (2010). Como elaborar projetos de pesquisa. São Paulo: Atlas, 2010 .

GIL, Antônio Carlos (2011). Métodos e técnicas de pesquisa social. São Paulo: Atlas, 2011.

GOMES, Romeu. Análise de dados em pesquisa qualitativa. In: MINAYO, M.C.S.(org.). Pesquisa social: teoria, método e criatividade. Petrópolis: Vozes, 2002.

GROPPO, Luís Antônio. “A Juventude como Categoria Social”, Juventude: Ensaios sobre Sociologia e História das Juventudes Modernas. Rio de Janeiro: DIFEL, 2000.

HOLLIDAY, Oscar Jara. Para sistematizar experiências. Brasília: Ministério do Meio Ambiente, 2006.

IANNI, Aurea Maria Z. O campo temático das ciências sociais em saúde no Brasil. Tempo Social Revista de sociologia da USP, v. 27, n. 1, 2015.

LABORATÓRIO DE HABITAÇÃO E ASSENTAMENTOS HUMANOS DA FAU/USP - LABHAB. Programa Bairro Legal Plano de Ação Habitacional e Urbano. Diagnóstico Jardim Ângela. Faculdade de Arquitetura e Urbanismo da Universidade de São Paulo: São Paulo, 2003.

LAKATOS, Eva Maria; MARCONI, Marina de Andrade (1991). Fundamentos da metodologia científica. São Paulo: Atlas, 1991. 
LAVILLE, Christian; DIONNE, Jean. A construção do saber - manual de metodologia da pesquisa em ciências humanas. Porto Alegre: Artmed; Belo Horizonte: Editora UFMG, 2008.

LIMA, Cauê Nogueira de. O fim da era FEBEM: novas perspectivas para o atendimento socioeducativo no estado de São Paulo (Dissertação de Mestrado). São Paulo: Universidade de São Paulo, 2010.

LIMA, Lana L.G. História social da criança e da família. In: Revista de História. Universidade de São Paulo, n. 117, 1984.

LISPECTOR, Clarice. Um sopro de vida (pulsações). Rio de Janeiro: Rocco, 1999.

LYRA, Diogo. A república dos meninos - juventude, tráfico e virtude. Rio de Janeiro: Mauad X: FAPERJ, 2013.

MALVASI, Paulo Artur. Interfaces da vida loka: um estudo sobre jovens, tráfico de drogas e violência em São Paulo (Tese de Doutoramento). São Paulo: Universidade de São Paulo, 2012.

MANNHEIM, Karl. O problema sociológico das gerações. In. FORACHI, Maria Alice (org.). Mannheim, Grandes Cientistas Sociais n. 25. São Paulo: Ática, 1982. p. 67-95.

MARCILIO, Maria Luiza. A roda dos expostos e a criança abandonada na História do Brasil 1726-150. In: FRETAS, Marcos Cezar. História Social da Infância no Brasil. São Paulo: Cortez, 1997.

MARQUES, Adalton. Humanizar e expandir: uma genealogia da segurança pública em São Paulo (Tese de Doutoramento). São Carlos: Universidade Federal de São Carlos, 2017.

MARTINS, R. Geografia Humana dos Bairros de Colônia Paulista e Ilha do Bororé (Distritos de Parelheiros e Grajaú) in MARTINS, Rodrigo "APA BORORÉ: Subsídios à implantação - Praticando Geografia com a Teoria do Geossistemas" São Paulo: FFLCH-USP, 2003.

MATSUDA, Fernanda Emy. A medida da maldade - Periculosidade e controle social no Brasil (Dissertação de Mestrado). São Paulo: Universidade de São Paulo, 2009.

MBEMBE, Achille. Necropolítica. Arte \& Ensaios, Revista do PPGAV/ EBA/ UFRJ, n.32, dez. 2016.

MENEZES, Jaileila A. et. al. Implicações políticas na pesquisa-intervenção com jovens. Revista de Psicologia, Fortaleza, v.9 n.1, 2018.

MERHY, Emerson. Saúde: cartografia do trabalho vivo em ato. São Paulo: Editora Hucitec, 2002. 
MIAGUSKO, Edson. Esperando a UPP: Circulação, violência e mercado político na Baixada Fluminense. Revista Brasileira de Ciências Sociais - vol. 31, 912016.

MINAYO, M.C.S.(org.). Pesquisa social: teoria, método e criatividade. Petrópolis: Vozes, 2002.

MINISTÉRIO DA SAÚDE. Secretaria de Atenção à Saúde. Departamento de Ações Programáticas Estratégicas. Cadernos de Atenção Básica, n. 34 - Saúde Mental. Brasília: Ministério da Saúde, 2013.

MINISTÉRIO DO DESENVOLVIMENTO SOCIAL E COMBATE À FOME. Caderno de Orientações Técnicas: Serviço de Medidas Socioeducativas em Meio Aberto. Secretaria Nacional de Assistência Social. Brasília, Distrito Federal: 2016.

MINISTÉRIO DO DESENVOLVIMENTO SOCIAL E COMBATE À FOME. Concepção e gestão da proteção social não contributiva no Brasil. Brasília: MDS, UNESCO, 2009a.

MINISTÉRIO DO DESENVOLVIMENTO SOCIAL E COMBATE À FOME. Norma Operacional Básica de Recursos Humanos do SUAS (Reimpressão). Secretaria Nacional de Assistência Social. Brasília, 2009b.

MINISTÉRIO PÚBLICO DO ESTADO DE SÃO PAULO. Panorama geral dos serviços de medidas socioeducativas de meio aberto no Município de São Paulo. Núcleo de Assessoria Técnica Psicossocial (NAT). São Paulo, 2018.

MISSE, Michel. Crime e violência no Brasil contemporâneo: estudos de sociologia do crime e da violência urbana. Rio de Janeiro: Lummen Juris, 2011.

MONCEAU, Gilles. Transformar as práticas para conhecê-las: pesquisa-ação e profissionalização docente. In: Educação e Pesquisa, São Paulo, v. 31, n. 3, 2005.

MONTEIRO, Renata A. P.; CASTRO, L. R. A concepção de cidadania como conjunto de direitos e sua implicação para a cidadania de crianças e jovens. Rev. psicol. polít., São Paulo, v. 8, n. 16, 2008.

NOGUEIRA, Izildinha Baptista. Significações sobre o corpo negro (Tese de Doutoramento). São Paulo: Universidade de São Paulo, 1998.

OLÍVAR, José Miguel N. Performatividades governamentais de fronteira: a produção do Estado e da fronteira por meio de políticas de tráfico de pessoas na Amazônia Brasileira. Revista Ambivalências v. 3, n. 5, 2015.

OLIVEIRA, Adriano de; VICENTIN, M.C.G.; MASSARI, M.G. Entre medicalização e recusas: crianças e adolescentes nos circuitos socioassistenciais-sanitários. Rev. Polis e Psique, 8(3), 2018.

OLIVEIRA, Amurabi. A meninice no pensamento de Gilberto Freyre. Revista de Ciências Sociais, nº 43, 2015. 
OLIVEIRA, Denise Cabral. Adolescência e errância: destinos do laço social no contemporâneo. Cad. Psicanálise-CPRJ, Rio de Janeiro, ano 32, n. 23, 2010.

PAIS, José Machado. A construção sociológica da juventude - alguns contributos. Análise Social, vol. XXV (105-106), 1990.

PAIVA, Andrea Barreto et. al. Nota técnica n. 27. O Novo Regime Fiscal e suas implicações para a Política de Assistência Social no Brasil. Brasília: IPEA, 2016.

PAPPALIA, Diane; FELDMAN, Ruth. Desenvolvimento humano. Porto Alegre: Artmed / AMGH Editora, 2013.

PASSETTI, Edson. Crianças carentes e políticas públicas. In: Del Priore, Mary (org.). História das crianças no Brasil. São Paulo: Editora Contexto, 1999.

PASSOS, Eduardo; BENEVIDES, Regina de Barros. Por uma política da narratividade. In: PASSOS, Eduardo et.al. Pistas do método da cartografia - Pesquisa-intervenção e produção de subjetividade. Porto Alegre: Sulina, 2015.

PAULA, Liana. A Família e as medidas socioeducativas: a inserção da família na socioeducação dos adolescentes autores de ato infracional (Dissertação de Mestrado). São Paulo: Universidade de São Paulo, 2004.

PELÚCIO, Larissa. Abjeção e desejo: uma etnografia travesti sobre o modelo preventivo de aids. São Paulo: Annablume; Fapesp, 2009.

PEREIRA, Pedro P. G.. A teoria queer e a reinvenção do corpo. Cadernos Pagu, Campinas, n. 27, 2006.

PIMENTA, Melissa de Matos. Juventude e violência. In: LIMA, Renato Sérgio; RATTON, José Luiz; AZEVEDO, Rodrigo Ghiringhelli de (org.). Crime, polícia e justiça no Brasil. São Paulo: Contexto, 2014.

RIZZINI, Irene et al. (coord.). Acolhendo crianças e adolescentes: experiências de promoção do direito à convivência familiar e comunitária. São Paulo: Cortez, 2007.

RUSSO, Jane; CARRARA, Sergio L. Sobre as ciências sociais na Saúde Coletiva com especial referência à Antropologia. Physis Revista de Saúde Coletiva, Rio de Janeiro, 25 [ 2 ], 2015.

PRADO, Guilherme do Val Toledo; SOLIGO, Rousara; SIMAS, Vanessa França. Pesquisa narrativa em três dimensões. Anais VI CIPA - Congresso Internacional de Pesquisa (Auto)Biográfica - Modos de Viver, Narrar e Guardar. Rio de Janeiro, 2014.

REDE NOSSA SÃO PAULO (2017). Mapa da desigualdade 2017. Disponível em: <https://www.nossasaopaulo.org.br/portal/arquivos/mapa-da-desigualdade-2017.pdf>. Acesso em 25.07.2018. 
RIBEIRO, Igor Gabriell; BENELLI, Sílvio. Jovens negros em conflito com a lei e o racismo de Estado. Revista Interdisciplinar de Direitos Humanos da Universidade Estadual de São Paulo, Bauru, v. 5, n. 1, jan./jun., 2017.

RIZZINI, Irene. Reflexões sobre pesquisa histórica com base em ideias e práticas sobre a assistência à infância no Brasil na passagem do século XIX para o XX. In: Anais I Congresso Internacional Pedagogia Social Faculdade de Educação, Universidade de São Paulo 2006. Disponível em: <http://www.proceedings.scielo.br/scielo.php?script=sci_arttext\&pid=MSC0000000092 006000100019\&lng=en\&nrm=iso> Acesso em: 13.01.2018.

RIZZINI, Irene; BUSH, Malcolm. As infâncias do mundo. Reflexões sobre diversidade e perspectivas de inclusão. Inclusão Social, Brasília, v. 1, n. 2, 2006.

RODRIGUES, Patrícia D'Elboux. A provisoriedade do abrigo e a produçã de afetos: estudo sobre assujeitamento / resistência em adolescentes inseridos em unidades de acolhimento. Curitiba: Appris, 2015.

SANTIBANEZ, Dione Antonio et. al. As narrativas do medo e a criminalização da juventude: o discurso punitivo contra adolescentes em conflito com a lei. Inter-Ação, Goiânia, v. 40, n. 2, 2015.

SANTOS, Ana Paula. A participação social na saúde desenvolvida em um espaço não institucionalizado no Jardim Ângela: contribuições, limites e desafios para o Sistema Único de Saúde (Monografia de Especialização em Saúde Coletiva). São Paulo: Universidade de São Paulo - Faculdade de Medicina, 2016.

SANTOS, Milton. O dinheiro e o território. In: SANTOS, Milton; BECKER, Bertha K. (org.).Território, territórios: ensaios sobre o ordenamento territorial. Rio de Janeiro: Lamparina, 2007.

SANTOS, Milton. O retorno do território. In: SANTOS, Milton et. al. (org.). Território Globalização e fragmentação. São Paulo: Hucitec, 1998.

SARDERBERG, Agda. O Bairro-Escola Fundão do Jardim Ângela. In: SINGER, Helena (org.). Territórios educativos: experiências em diálogo com o Bairro-Escola. São Paulo: Moderna, 2015.

SAWAIA, Bader (org.). As artimanhas da exclusão: análise psicossocial e ética da desigualdade social. Rio de Janeiro: Vozes, 2008.

SCHUCH, Patrice. Antropologia entre o inesperado e o inacabado: entrevista com João Biehl. Horizontes Antropológicos, ano 22, n. 46, Porto Alegre, 2016.

SCHUCH, Patrice. Como a família funciona em políticas de intervenção social?. Civitas - Revista de Ciências Sociais, [S.1.], v. 13, n. 2, 2014.

SCISLESCKI, Andrea; GUARESCHI, Neusa Maria. Pensando o governo: produzindo políticas de vida e de extermínio. Athenea Digital, 11(2), 2011. 
SCISLESKI, Andrea Cristina et. al. Manicômio em circuito: os percursos dos jovens e a internação psiquiátrica. Cad. Saúde Pública, Rio de Janeiro, 24(2), 2008.

SCISLESKI, Andrea Cristina et. al. Racismo de Estado e tanatopolítica: reflexões sobre os jovens e a lei. Fractal: Revista de Psicologia, v. 28, n. 1, 2016.

SCISLESKI, Andrea. Governando vidas matáveis: as relações entre a saúde e a justiça dirigidas a jovens em conflito com a lei (Tese de Doutoramento). Pontifícia Universidade Católica do Rio Grande do Sul: Rio Grande do Sul, 2010.

SECRETARIA DE VIGILÂNCIA EM SAÚDE - MINISTÉRIO DA SAÚDE BRASIL. Boletim Epidemiológico - Sífilis, volume 48, n. 36, 2017.

SECRETARIA MUNICIPAL DE ASSISTÊNCIA E DESENVOLVIMENTO SOCIAL. Plano Decenal e atendimento socioeducativo do Município de São Paulo, 2015-2025. São Paulo: SMADS, 2016.

SECRETARIA NACIONAL DE JUVENTUDE. Agenda Juventude Brasil. Pesquisa Nacional sobre perfil e opinião dos jovens brasileiros 2013. SNJ - Observatório Participativo da Juventude: Brasília, 2013.

SILVA, Benjamin Campos; SAÚDE, Márcia Aparecida Ribeiro. Eixo Étnico-Racial nas Medidas Socioeducativas. São Paulo: Governo do Estado de São Paulo. Fundação CASA, 2010.

SILVA, Gustavo de Melo. Adolescente em conflito com a lei no Brasil: da situação irregular à proteção integral. Revista Brasileira de História \& Ciências Sociais Vol. 3 N. $5,2011$.

SINGER, Helena (org.). Territórios educativos: experiências em diálogo com o BairroEscola. São Paulo: Moderna, 2015.

SOARES, Luiz Eduardo. In: Juventude e violência no Brasil contemporâneo. In: NOVAES, Regina; VANNUCHI, Paulo (org.). Juventude e Sociedade - Trabalho , Educação , Cultura e Participação. São Paulo, Fundação Perseu Abramo/Instituto Cidadania, 2004.

SOUSA, Neusa Santos. Tornar-se negro: as vicissitudes da identidade do negro brasileiro em ascenção social. Rio de Janeiro: Edições Graal, 1983.

SOUSA, Osvaldo Domingues de. Análise de fatores extrajudiciais na determinação da medida socioeducativa (Dissertação de Mestrado). São Paulo: Universidade Anhanguera de São Paulo, 2015.

SOUZA, Marli Palma. Proteção integral e ato infracional: um estudo em Santa Catarina. Katálysis vol. 7, n. 2, Florianópolis, 2004.

SPINK, Mary Jane. Trópicos do discurso sobre risco: risco-aventura como metáfora na modernidade tardia. In: Cad. Saúde Pública, 17(6), Rio de Janeiro, 2001. 
SPOSATI, Aldaíza. Estudo da capacidade protetiva de famílias beneficiárias de Programas Federais de Transferências de Renda em regiões periféricas metropolitanas. Ministério do Desenvolvimento Social e Combate à Fome. Brasília: MDS, 2011.

STÜRMER, Arthur B.; COSTA, Benhur P. Território: aproximações a um conceitochave da geografia. Geografia, Ensino \& Pesquisa, Vol. 21, n.3, 2017.

TELLES, Vera da Silva. A cidade nas fronteiras do legal e ilegal. Belo Horizonte: Argvmentvm, 2010.

UNIVERSIDADE ESTADUAL DE CAMPINAS. Mapa da Juventude da Cidade de São Paulo - Relatório Final. Campinas, 2014.

VELLOSO, Luciana M. Capão Pecado: sem inspiração para cartão postal (Dissertação de Mestrado). Belo Horizonte: Universidade Federal de Minas Gerais, 2007.

VENANCIO, Renato P. Famílias abandonadas: Assistência à criança de camadas populares no Rio de Janeiro e em Salvador - séculos XVIII e XIX. Campinas: Papirus, 1999.

VICENTIN, Maria Cristina G. Criançar o descriançável. Apresentado em II Encontro Paulista de CAPS-I na Faculdade de Saúde Pública da USP. São Paulo, 2012. Disponível em <http://portal.sme.prefeitura.sp.gov.br/Portals/1/Files/27154.pdf > acesso em 04.03.2019.

VICENTIN, Maria Cristina G. Infância e adolescência: uma clínica necessariamente ampliada. Revista Terapia Ocupacional Universidade de São Paulo, v. 17, n.1, 2006.

VIEIRA, Fabiola S.; BENEVIDES, Rodrigo P.S. Nota técnica n. 28. Os impactos do Novo Regime Fiscal para o financiamento do Sistema Único de Saúde e para a efetivação do direito à saúde no Brasil. Brasília: IPEA, 2016.

WACQUANT, Loïc (2003). Punir os pobres: a nova gestão da miséria nos Estados Unidos. Rio de Janeiro: Revan, 2003.

WACQUANT, Loïc. A política punitiva da marginalidade: revisitando a fusão entre workfare e prisonfare. Revista EPOS; Rio de Janeiro - RJ; Vol.3, $\mathrm{n}^{\circ}$ 1, janeiro-junho de 2012.

WAISELFISZ, Julio Jacobo. Mapa da violência, homicídios por armas de fogo no Brasil. Brasília: Ministério da Justiça e Cidadania, Secretaria Especial de Políticas de Promoção da Igualdade Racial, FLACSO Brasil, 2016.

WEISHEIMER, Nilson. Marialice Foracchi e a Formação da Sociologia da Juventude no Brasil. BIB, São Paulo, n. 77, 2014.

ZALUAR, Alba. A integração perversa: pobreza e tráfico de drogas. Rio de Janeiro: FGV, 2004. 
ZALUAR, Alba. Etos guerreiro e criminalidade violenta. In: LIMA, Renato Sérgio; RATTON, José Luiz; AZEVEDO, Rodrigo Ghiringhelli de (org.). Crime, polícia e justiça no Brasil. São Paulo: Contexto, 2014. 


\section{ANEXOS}

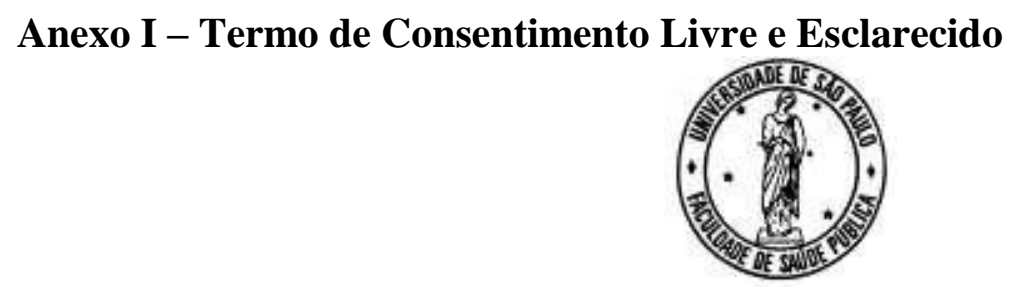
Universidade de São Paulo Faculdade de SaúdePública Av. Dr. Arnaldo, 715 - CEP o1246-904 - São Paulo - Brasil

TERMO DE CONSENTIMENTO LIVRE E ESCLARECIDO

I - DADOS DE IDENTIFICAÇÃO DO SUJEITO DA PESQUISA E RESPONSÁVEL LEGAL

1. Dados de Identificação

Nome:

Identidade $\mathrm{n}^{\mathrm{o}}$ : Sexo: ( ) $\mathrm{M}(\mathrm{F}$ Idade

Data de Nascimento: $. .1 \ldots \ldots . . . . . .1$

Endereço: $\mathrm{N}^{\mathrm{o}}:$ Apto:

Bairro: Cidade:

Telefone:.

2. Responsável Legal (somente em caso de adolescente menor de 18 anos):

Nome: Idade

Natureza (grau de parentesco, tutor, curador, etc.):

Documento de Identidade . $^{\circ}$ : Sexo: ( ) M ( ) F

Data de Nascimento:

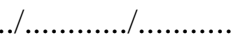

Endereço: $\mathrm{N}^{\mathrm{o}}$ :. Apto:

Bairro: Cidade:

Telefone:

\section{II - DADOS SOBRE A PESQUISA}

1. Título do Projeto de Pesquisa (Título Provisório): Juventude, Estado e conflitos - atendimento socioeducativo em São Paulo, subjetividades e violências

Pesquisadores: Diego Sousa de Carvalho

E-mail: didz@usp.br / Telefone: (11) 99319-1942

Pesquisadora Orientadora: Prof. a Dra. Cleide Lavieri Martins

E-mail: cleide@usp.br

Faculdade de Saúde Pública da Universidade de São Paulo 


\title{
2. Avaliação de Risco da Pesquisa
}

\author{
(X) Risco Mínimo \\ ( ) Risco Médio \\ ( ) Risco Maior \\ (Probabilidade de que o indivíduo sofra algum dano como consequiência imediata ou tardia do \\ estudo).
}

3. Duração da Pesquisa: 2 meses de coleta de dados em campo, com até 2 encontros semanais

\section{III - REGISTRO DAS EXPLICAÇÕES DO PESQUISADOR AO SUJEITO DA PESQUISA OU SEU REPRESENTANTE LEGAL SOBRE A PESQUISA, CONSIGNANDO:}

1. Justificativa e os objetivos da pesquisa: A pesquisa reúne relatos de jovens em atendimento e profissionais que atuam no sistema socioeducativo.

2. Procedimentos que serão utilizados e propósitos; incluindo a identificação dos procedimentos que são experimentais: Entrevistas semiestruturadas individuais e oficinas em grupo.

3. Desconfortos e riscos esperados: A pesquisa conta com risco mínimo de desconforto e busca criar espaços seguros de diálogos junto aos jovens e profissionais. Os sujeitos têm assegurado sigilo sobre suas identidades e informações, os mesmos não serão identificados na transcrição escrita das entrevistas. A pesquisa tem fins exclusivamente acadêmicos, não podendo ser utilizada para outros meios.

4. Benefícios que poderão ser obtidos para o sujeito da pesquisa e/ou coletividade: Espera-se promover a reflexão sobre questões de cidadania e projetos de vida da juventude. Busca-se compartilhar os conhecimentos a respeito dos temas da juventude, racismo, direitos humanos, de modo a promover o debate de relevância social.

\section{IV - ESCLARECIMENTOS DADOS PELO PESQUISADOR SOBRE GARANTIAS DO SUJEITO DA PESQUISA}

1. Acesso, a qualquer tempo, às informações sobre procedimentos, riscos e benefícios relacionados à pesquisa, inclusive para dirimir eventuais dúvidas (fornecer endereço e telefone para contatos do(s) pesquisador(es) e do Comitê de Ética da Faculdade de Saúde Pública);

2. Liberdade de retirar seu consentimento a qualquer momento e de deixar de participar do estudo, sem que isto traga prejuízo à continuidade da assistência;

3. Salvaguarda da confidencialidade, sigilo e privacidade;

\section{V - INFORMAÇÕES DE NOMES, ENDEREÇOS E TELEFONES DOS RESPONSÁVEIS PELO ACOMPANHAMENTO DA PESQUISA PARA CONTATO EM CASO DE INTERCORRENCIAS CLÍNICAS E REAÇÕES ADVERSAS}

Comitê de Ética em Pesquisa da Faculdade de Saúde Pública da Universidade de São Paulo, sito à Av. Dr. Arnaldo, 715, Cerqueira César - CEP 01246-904, São Paulo, SP - Telefone: (11) 3061-7779 - e-mail: coep@fsp.usp.br

São Paulo, , de de 2018

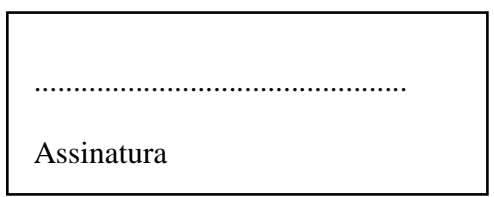

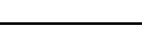

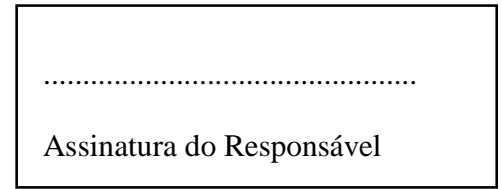

Diego Carvalho (Pesquisador) 


\section{Anexo II - Carta de Anuência de Pesquisa em Instituição \\ Modelo de Termo de Assentimento de Pesquisa em Instituição}

\section{(Este será entregue junto ao TCLE)}

$\mathrm{Eu}$, portador (a) do documento de Identidade (se já tiver documento), responsável pela instituição fui informado (a) dos objetivos da presente pesquisa, de maneira clara e detalhada e esclareci minhas dúvidas, tendo recebido todas as informações constantes em Anexo II - Termo de Consentimento Livre e Esclarecido, e AUTORIZO a realização de pesquisa nesta instituição. Sei que a qualquer momento poderei solicitar novas informações, e poderei modificar minha decisão se assim o desejar. Declaro que concordo em participar dessa pesquisa. Recebi o presente Termo de Assentimento e o Termo de Consentimento Livre e Esclarecido, e me foi dada a oportunidade de ler e esclarecer as minhas dúvidas.

São Paulo, , de de 2018

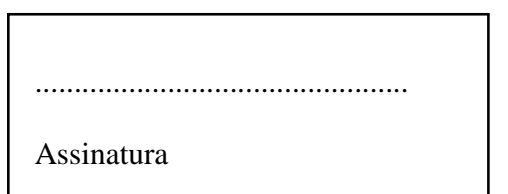

Diego Carvalho (Pesquisador) 


\section{Anexo III - Roteiros de Entrevistas}

\section{Roteiro inicial de entrevistas}

1. Me fale sobre o histórico da instituição e sua atuação no território;

2. Me fale sobre sua experiência de atuação com a juventude em atendimento socioeducativo (ou juventude, em geral). Há quanto tempo? Que mudanças você percebe neste cenário ao longo de sua experiência?

3. Você pode compartilhar algum caso que tenha acompanhado que lhe mobilizou?

4. Quais recomendações você daria aos pesquisadores(as) que desejam compreender as dinâmicas do sistema socioeducativo? 


\title{
Anexo IV - Ata de Defesa do Programa de Pós-Graduação em Saúde Pública
}

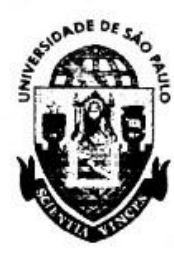

Janus

\author{
Universidade de São Paulo
}

ATA DE DEFESA

Aluno: $6143-7702562$ - 1 / Página 1 de 1

Ata de defesa pública de Tese do(a) Senhor(a) Diego Sousa de Carvalho no Programa: Saúde Pública, do(a) Faculdade de Saúde Pública da Universidade de São Paulo.

Aos 04 dias do mês de abril de 2019, no(a) Sala Diógenes Augusto Certain realizou-se a Defesa da Tese do(a) Senhor(a) Diego Sousa de Carvalho, apresentada para a obtenção do titulo de Doutor intitulada:

"Quando o Estado bate à porta - faces do Estado e narrativas sobre a juventude no atendimento socioeducativo na Zona Sul de São Paulo"

Após declarada aberta a sessão, o(a) Sr(a) Presidente passa a palavra ao candidato para exposição e a seguir aos examinadores para as devidas arguições que se desenvolvem nos termos regimentais. Em seguida, a Comissão Julgadora proclama o resultado:

Nome dos Participantes da Banca

Cleide Lavieri Martins

José Miguel Nieto Olivar

Elizabete Franco Cruz

Cássio Silveira

$\begin{array}{ll}\text { Função } & \text { Sigla da CPG } \\ \text { Presidente } & \text { FSP - USP } \\ \text { Titular } & \text { FSP - USP } \\ \text { Titular } & \text { EACH - USP }\end{array}$

Suplente

FCMSCSP - Externo

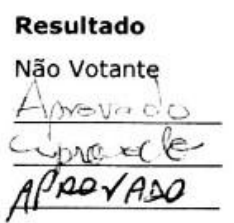

Resultado Final: tperaglo

Parecer da Comissão Julgadora *

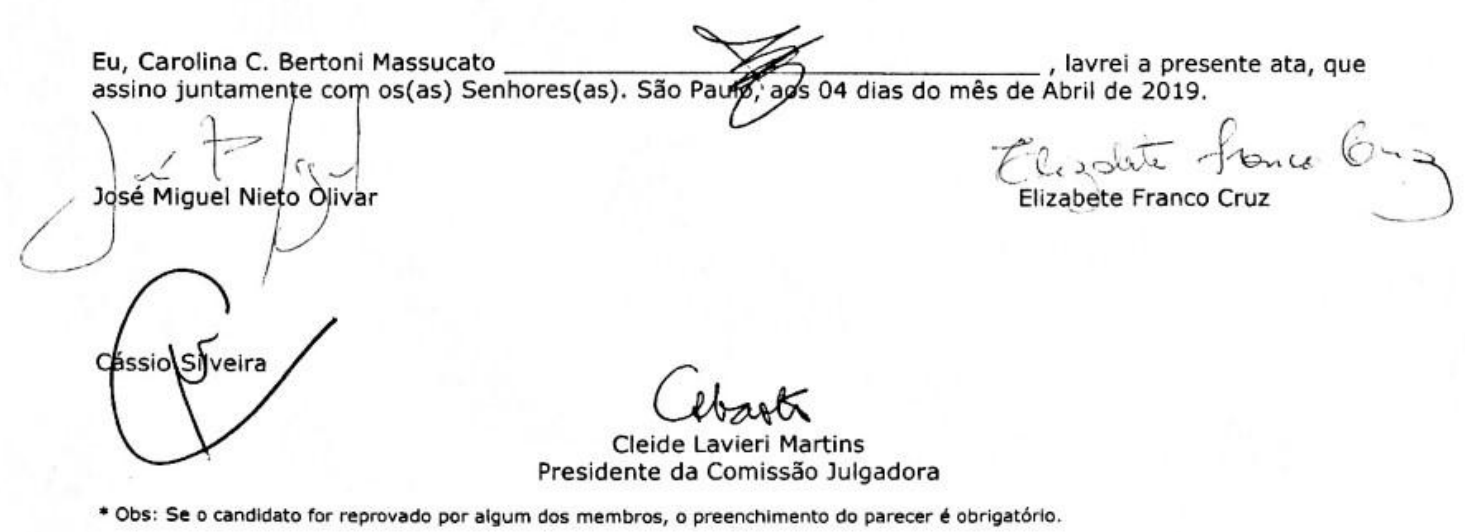


Anexo V - Comprovante de submissão de artigo, em conformidade com as normas do Regimento do Programa de Pós-Graduação em Saúde Pública

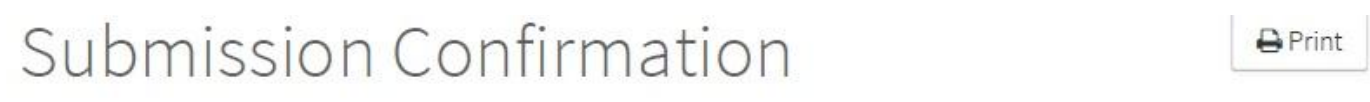

Thank you for your submission

\section{Submitted to}

Ciência \& Saúde Coletiva

Manuscript ID

CSC-2019-1577

Title

Estado, juventude e narrativas do sistema socioeducativo: direitos humanos, saúde e políticas sociais

Authors

Carvalho, Diego

Date Submitted

31-May-2019 


\section{Anexo VI - Comprovante de aceite de artigo}

Decision Letter (CSC-2019-3047)

From:

To: di_sc@msn.com

cC: cienciasaudecoletiva@fiocruz.br,

Subject: Ciência \& Saúde Coletiva - Decision on Manuscript ID CSC-2019-3047

Body: 19-Dec-2019

Carvalho, Diego:

It is a pleasure to accept your manuscript entitled "Estado, juventude e narrativas do sistema socioeducativo: direitos humanos, saúde e politicas sociais" for publication in the Ciência \& Saúde Coletiva. It is a pleasure to accept your manuscript entitled "Estado, juventude e narrativas do sistema socioeducativo: direitos humanos, saúde e politicas sociais" for publication in the Ciência \& Saúde Coletiva.
In order for your manuscript to be edited, we would ask that you include the text in a single fle with the: (1) Title (in Portuguese and in the foreign language); (2) Authors (fulll name, institution, e-mail and ORCID);
(3) Summary (in Portuguese and in the foreign language); (4) Keywords (in Portuguese and in the foreign language); (5) Full text of the article (from the introduction to the references) and (6) Illustrative material (i We note that this file, which cannot be in PDF format, must have the same content as the manuscript which was reviewed. It is this version which shall be published. Whe file and the declarations attached should be sent to the e-mail: cienciasaudecoletiva@fiocruz. br

Thank you for your contribution.

From now on, we will highlight articles for special promotion monthly on the Journal's Facebook account. Therefore, if you have an account in this social network, we ask you to like the Ciência \& Saúde Coletiva Page facebook.com/revistacienciaesaudecoletiva

Prezado(a) Dr. Carvalho:

É um prazer aceitar o seu manuscrito intitulado "Estado, juventude e narrativas do sistema socioeducativo: direitos humanos, saúde e politicas sociais" para publicacãão na revista Ciência \& Saúde Coletiva.
Para que o seu manuscrito seja editorado, solicitamos que você reúna em um único arquivo um texto com: (1) Titulo (em portuguếs e na língua estrangeira); (2) Autores (nome completo, instituição, e-mail e ORCID); (3) Resumo (em português e na língua estrangeira); (4) Palavras-Chave (em português e na língua estrangeira); (5) Corpo completo do artigo (indo desde a introdução até as referências) e (6) Material ilustrativo Observamos que esse arquivo - que não pode ser em formato de PDF - deve ter o mesmo conteúdo do manuscrito que foi avaliado. É essa versão que será publicada.

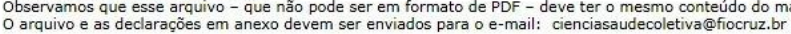

Obrigado pela sua contribuição.

A partir de agora, destacaremos mensalmente alguns artigos para divulgação especial no Facebook da Revista. Portanto, caso você possua conta nessa rede social, solicitamos que curta a página da Revista Ciência \&

facebook.com/revist

Sincerely, / Atenciosamente,

Dr. Romeu Gomes
Editor-in-Chief, Ciência \& Saúde Coletiva
romeugo@gmail.com 
Anexo VII - Currículo Lattes do Pesquisador

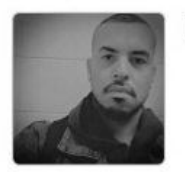

\section{Diego Sousa de Carvalho}

Endereşo para acessar este CV: http://lattes.cnpq.br/9440662724502108

Útima atualização do currículo em 21/12/2019

Resumo informado pelo autor

Doutor em Saúde Pública pela Universidade de São Paulo - USP (2019). Possui Mestrado em Saúde Pública pela Universidade de São Paulo - USP (2014). Especialista em Gestão de Políticas Públicas com ênfase em políticas sociais de Gênero e Raça pela Universidade Federal de Ouro Preto - UFOP (2012). Graduação em Psicologia pela Universidade Anhembi Morumbi (2019) e em Filosofia pela Universidade Federal de São Paulo - UNIFESP (2010). Áreas de Interesse: Políticas públicas (políticas sociais); Direitos Humanos; Saúde Pública e Coletiva; Saúde Mental; Ciências Sociais em Saúde.

(Texto informado pelo autor)

Extraído de: < http://lattes.cnpq.br/9440662724502108 > Acesso em 21.12 2019. 